Historic, archived document

Do not assume content reflects current scientific knowledge, policies, or practices. 



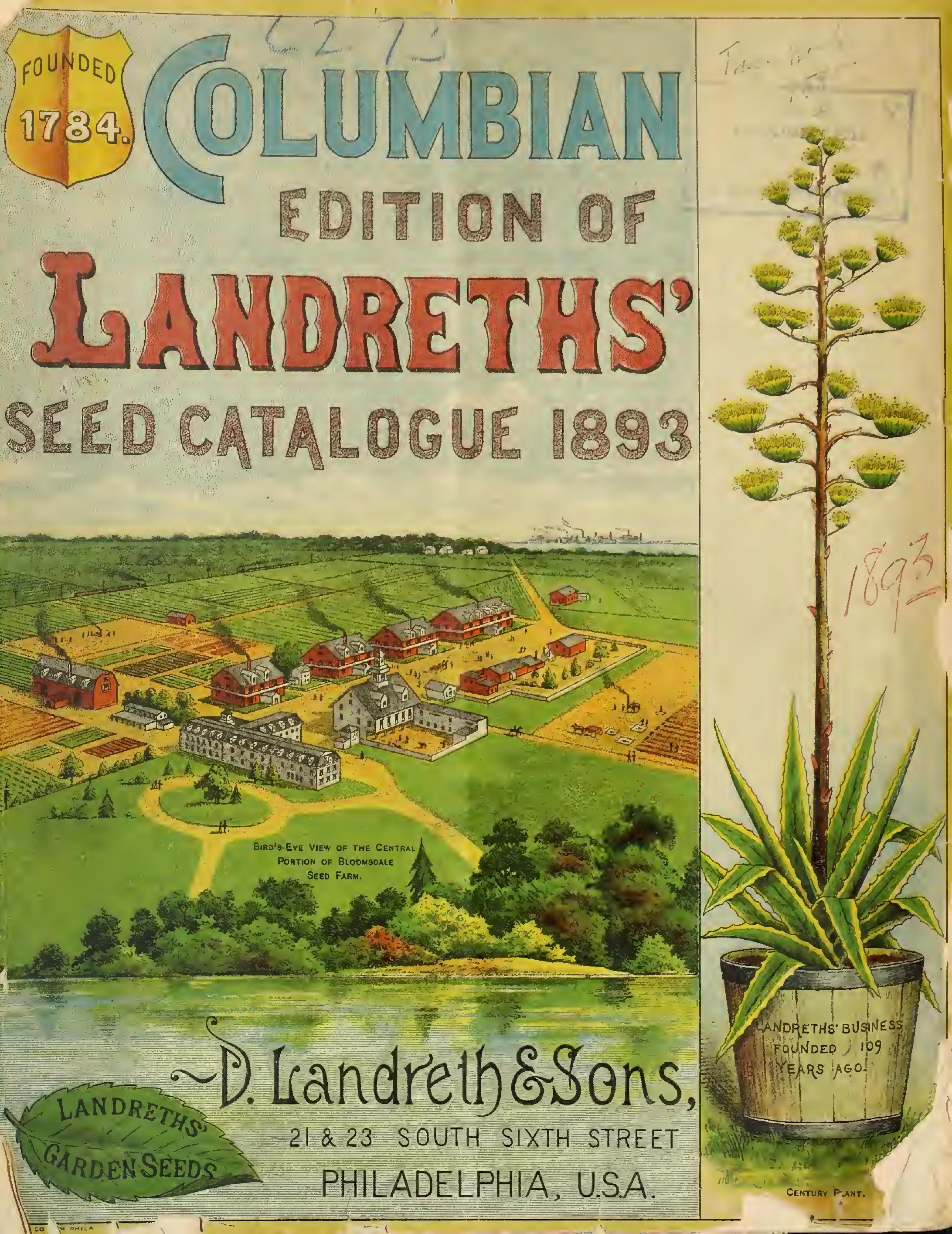




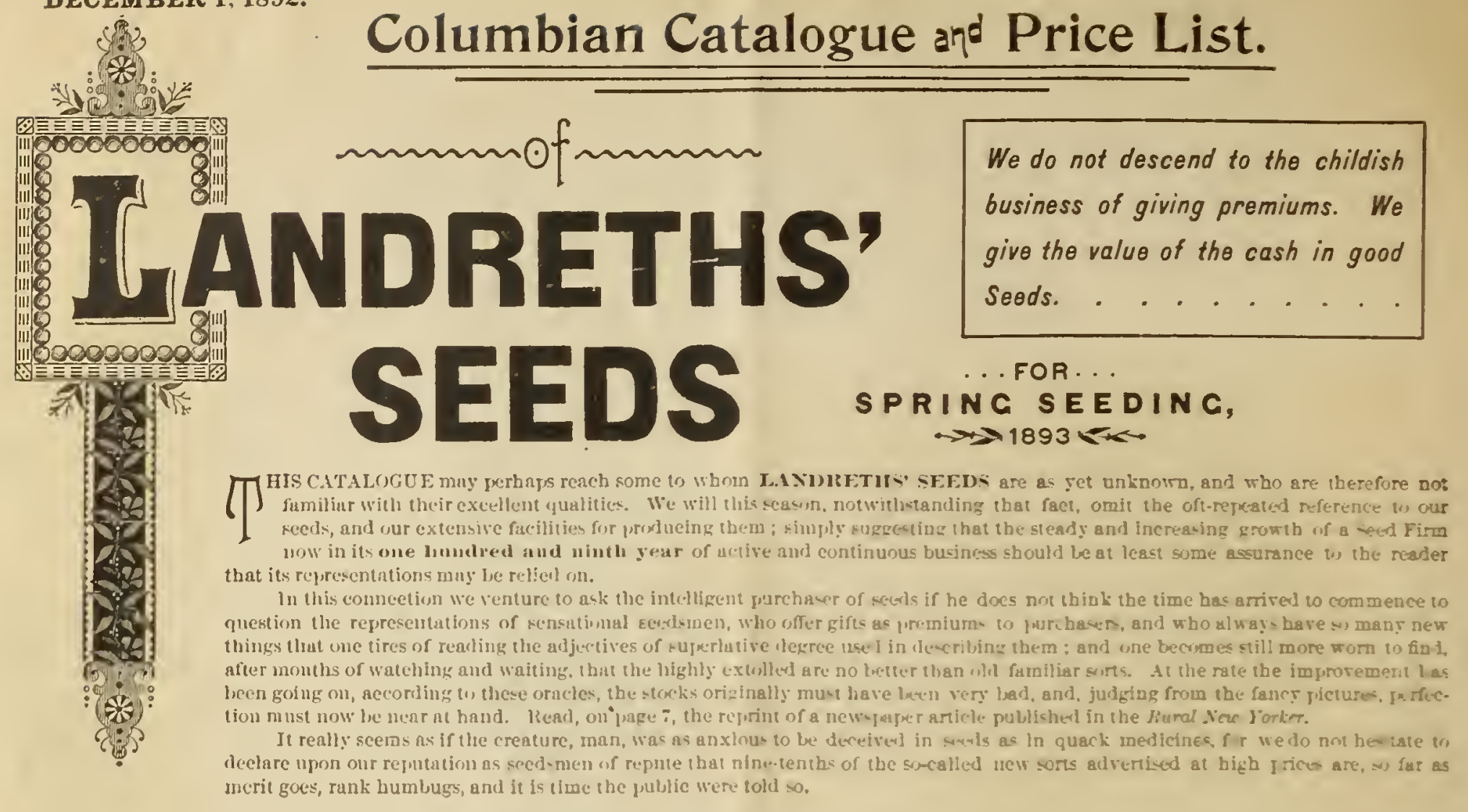

\section{INSTRUCTIONS}

TERMS CASH WITH ORDER.only : Irhen urices flnctunte

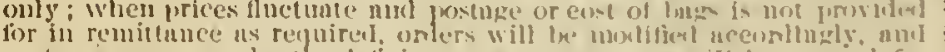

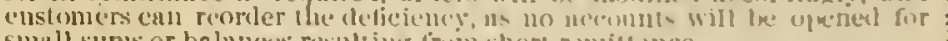
small suns or balunces resultimg from short remillance.

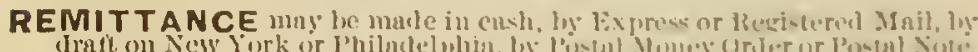

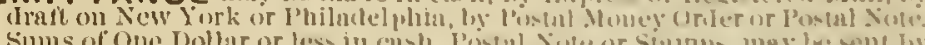

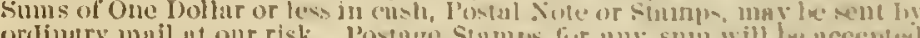

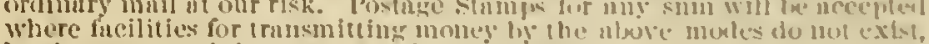
but letters contuining santestumla be registered

BY MAIL-POSTACE PAID BY US. - Wr will mul, mo-tmill, al

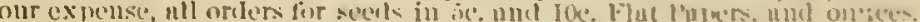
Pens, 33 cuns und corn exépled.

BY MAIL-POSTACE PAID BY PURCHASER,-On भนH

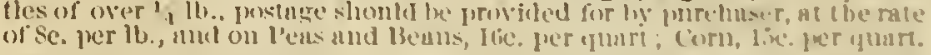

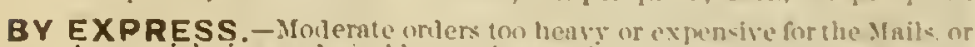

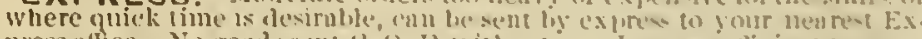

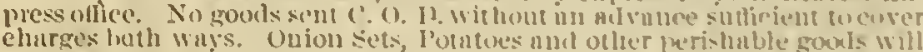
eharges huth ways.

BY FREICHT li. R. or stemer.-0rilen for heary serets, such as Pea

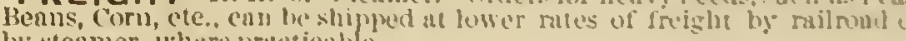
by steamer, where prateticulde.
PACKACE CHARCES. - Wher lase, cmes or larn is are neruinerl f:

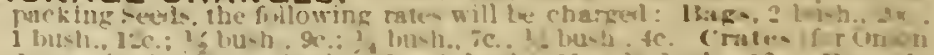

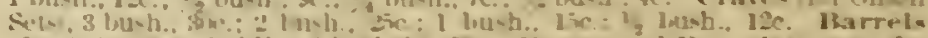

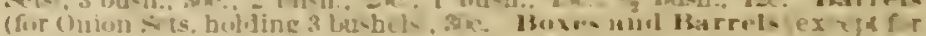

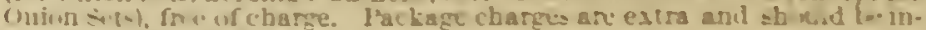
cluded in remittance.

MAKINC OUT ORDERS. - We always mak, it a gaint to givetrite

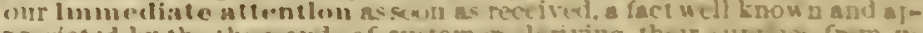

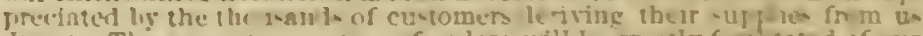

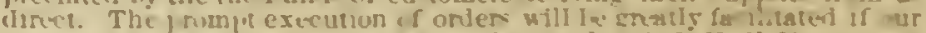

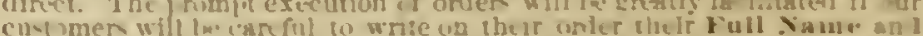

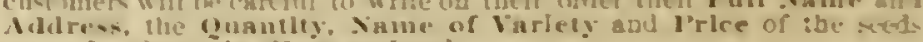

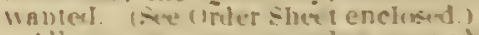

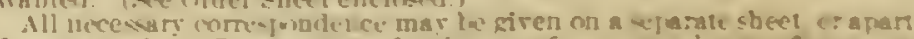

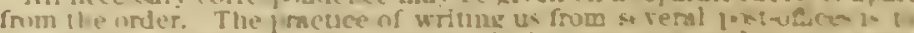

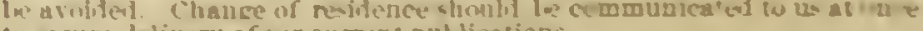

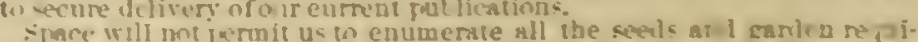

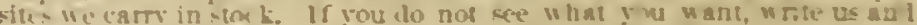
ile will promply gave rou frices and all cher inf rmation.

The prices in this catalosue are coustanty TE sinject to Finctuations, nind, Tincerore,

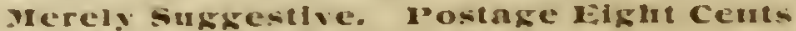
per lound Fitra if by indi.

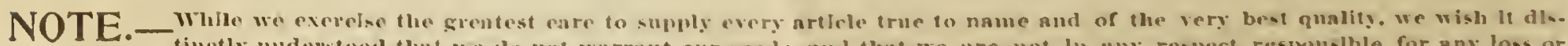

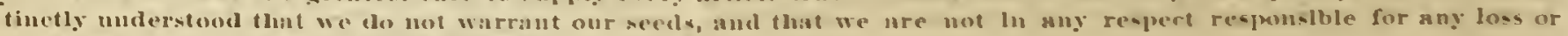
damage urisiug from wuy falluro thereof.

Address plainly, D. LANDRETH \& SONS, Philadelphia, Pa.

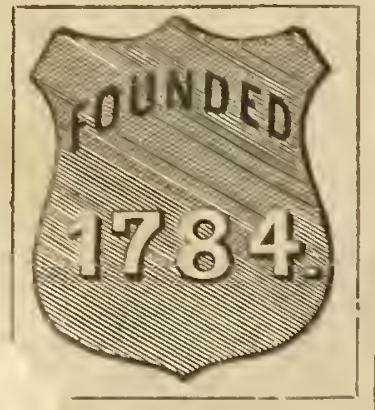

Market Gardeners and Institutions requiring seeds in large quantities will be given special rates upon submitting their orders.

\section{LANDRETH \& SONS,}

Fractical Seed Farmers and MIerchants simce 1 T 1. 


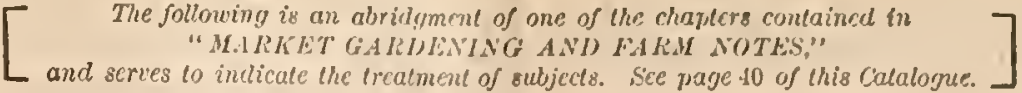

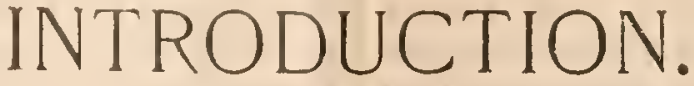

\section{THE Grass QUESTION.}

"Go to grass" is a slangy expression, but one whieh without offense, indeed with the best of notives, night be said to a multitude of farmers in the corn-growing States and to a still greater number in the cottoll States of this country.

It may be stated in a general may that the eapacity of land to grow desirable grasses is the measure of its ag!:cultural value and the extent and sueeess in the praetice of growing grass indieates the degree of advaincement of a farmer in the sealc of merit, for; without grass, although he may produee some poor stringy beef, he cannot grow good inutton $110 \mathrm{r}^{\circ}$ wool, nor will lic liave plenty of hay, and following and as an outgrowtl of good hay and lots of it, that important farm manulaetory known as the barnyard-witness the half-million falms in the South which never knew a barnyard in its practical sense as a manufactory for manure.

The farm, county or statc which cannot produce its omn pasturage for Spring, Summer and A utumn, and its own hay for Winter, is only half way up in the agrieultural seale, be its other crops ercr so profitable, for it is a dependant on other sections for an agrieultural staplc.

In locations where sueh protracted drought prevails as to burn up the present standard perennial grass, there are badly needed other varieties of grasses whieh will resist drought and remaining green under lot sun continue to furnish a nutritious bite when otlers have succumbed. Bermuda grass, a perennial from the West Indies, to some extent fills the requirements, but it has the objeetionable charaeteristics of somctimes making itself a nuisance by its persistence.

While the test of years and the expericnce of nations point to certain perennial varietics of grass as standards on ordinaly farming soils, it sometimes occurs that wild or native sorts have high merit in their respective locality. For instance, many of the so-called wild annual grasses of the Southeru States so frequently loolied upon by the planter as nuisances, especially those that strive to take possession of cultivated fields during conditions of Summer heat, almost deadly to standard rarieties of grass and other furm crops, are many of them, even though some be ammual sorts, just the types to carry coarse-wooled American sheep through sueh trying seasons, conditions more serious to contemplate than the finding of Winter subsistenee. For in respect to Winter feeding of sheep or other cattle the South has a great advantage over the North in possessing a elimate eneouraging grass to grow continuously, an elimination from the costs of sheep husbandry of the Northern ex- penses of housing the animals and the stolage and eosts of Winter feeding.

The physical characteristics of grasses must be studied by the thoughtful farmer as respects their adaptability to his special soils, climatc and pulpose; for instance, varieties doing well on dry land should not be sown on heary, low, damp situations, nor others affording a luxuriant and nutritious feed for pastured eattlc, but of a habit of forming high tussocks, should not be sown with the expectation of machinc mowing; nor again slould other sorts specially adipted to cutting green and feeding in the pen or stable, but which like Lucelne have their crowns so elevated above the earth level as to be nibbled off by slicep, be sown for shcep grazing.

Profitable farming in the Southern States can best be developed and diversified by diverting from the ordinary system of cultivation or worse neglect, large areas to pasturage and hay fields of Bluc grass, Clover, Alfalfa, Alsike and Incarnatum, or better in some loeations wild grasses, thus enabling planters to 'feed some millions of sheep and clip six times as many millions of unwashed wool, supplemental to which would follow an extended culture in cor'n and oats.

It is self-erident that to realize the wealth whieh mil. lions of sheep with their mutton and wool would add to the South there must be less acreage in eotton and a greater aercagc in grass, for, while IIexiean sheep having some of the qualities of the goat may live on such stuff as thistles and cactus, the finer-bred sheep must liave an ample supply of succulent grass, with hay, corn and oats. There is an old proverb which is very true, " no grass no cattle, no cattle 110 manure, no nanure no crops;" or to illustrate the idea in other language, there is a French proverb that grass is a synony' $\mathrm{m}$ for "bread, beef, mutton and clothing."

Sheep farming naturally follows an adrance in grass farming, but the grass must be provided before the sheep. When obtaincd the two preserve the fertility of good lands and under good mallagement restore those elassed as unfertile and enrich the State. Nearly every farm of 200 acres arable land can support a flock of thirty to forty sheep, and if it is not in condition to do so, its owner should not jest till with elover, corn, rye and other green manures he has brought up his farm to that desirable condition.

He need have little fear of overproduction of mool, as the amnual consumption in the United States amounts to $600,000,000$ pounds of unwashed wool which may be estimated as the clip from 100,000,000 sheep. "The 
Census Bureau of 1890 gives the total number of sheep in the United States as $43,000,000$, of a value of 116 ,000,000 of dollars and cutting $290,000,000$ pounds of unwashed wool.

And just here in connection with the extension of grass culture on poor lands, much may be said in favor of green manuring as a preparation of lands to sustain a crop of grass. For example, il often occurs that thin soils, which without the expensive stimulus of commelcial fertilizers will not develop a fair sod of the standard perennial grasses, will yet grow a passable Spring crop of broadcasted corn to a beight of two or three feet. This plowed down before Midsummer and the field again immediately broadcasted with a second sowing of corn to be plowed down in $\Lambda$ utumn and followed by a broadcasted crop of rye to be plowed down in February or March will be found to have a marvelous fertilizing effect in sustaining grass or any otler crop. The man who pursues such a course of rejurenation of his land should lave his taxes remitted, for be is a good example in any locality and sluould be encouraged. The corn and rye system of green manuring knocks the slow process of clover renovation out of sight. Cultivated grasses of biennial habit are few of them, after being down for several years, entirely able to take care of themselves, hut must be assisted by harrowing and seeding on bare spots, top dressing with fertilizer and rolling. Worn-out pastures ean be renovated to a inarked degree by the application of lone phosplates, dried fish, meat and blood, and the nitrate salts. Of late in Europe much attention has been directed to the use of a $11 \times$ fertilizer known as slag phospliate, a ly-produet of the Basic proeess of making Bessemer steel. 'This slag phosphate seems especially adapted for grass and its trial is recommended.

Over three thousand varieties of plants of the grass family are known and deseribed by botanists, and while by far the greater laut are of such cluaracter as at once to remove them from the list of farm forage plants, there remains a vast number not cultivated. liarily tested, but worthy of experiment. 'l'he list of secels of forage grasses offered ly linropenu seed mereliants at the present day numbers over two bundred anmul, hiemial and peremial rarieties; but withont donbt the number will ere long be consider:aly extended, for there are many wild forms of grass all over the world well worthy of propagation, for example, some of the wild grasses of 'l'exas, Arizona and the Sonthwestern plains. rich when green and rery nutritions in the form of selfdried hay. Many of these may be much improred by critical selcetion, hybridization and evolution and be fitted for enltivation in all hivh dim altitudes of the cot ton belt. Among these wild grases of the plains the most common is the Gramma grass, a peremnial on the heavier soils and linowu botunically as Bouteloun oligos: tachya. It is found on all the great planins of the Sonthwest, growing in low enshion-like masses, forming a suceession of tussocks-a habit rendering it unsuitable for mowing even it it wew tall cuongh for las, which it does not. As a pasturage arass it is highly mutritions and cures rood hay on its own loot.

The next widely distributed variety an the prairie is the Buflilo oriss known as buchlö davtuloides, a native of the plains from Texas up to Missouri. It is a perennial affording a reliable supply of forage. In dry locations it is desirable as a lawn grass. It is of low habit, seldom rising over four inches and is inclined to grow ill tufts or patches. It is found in grentest breadths on the prairies in the vicinity of Mesquit trees. lience it is often called Mesquit grass. It possesses a root of long creeping luabit and unce established on congenial soil soon spreads over the land adjacent. Bearing few seeds it is consequently best propagated by enttings. When green it is sweet and nutritious, and dried as hay on the root is very palatable tu cattle. During dronghts when appearing to be about dead it springs into life upon a rain, becoming green in a fer hours and developing with phenomenal rajudity.

Either of these grasses no doubt can by selection be improved, as respects productiveness and durabilitythey are not refurred to as the only ones or the luest ones, but as examples of sorts already pasturerl upon br millions of horses, cattle and sheep. Why should not these and others le brought to the Southenstern States as most efficient aids in the diversification of agricultural practice?

Another American perennial grass not generally known lut of admimble cluaracter for southern sections, is the Texas l3lue grass (I'un ararhnifera), discovered on the prairies of that State in 1853 . It blossoms there about the last of March and ripens its seed about the middle of $A$ pril. Its habit in Southern States is unch stronger than hentucky lilue grass. In Texas, under the screrest dronglits, it sometimes lags a littlc. but after A utunn rains quickly springs into most vigrolous growth and continues to grow all Winter. It makes a strong top glowtl for hay and a inatted sod standing continued pasturing. It roots decply and spreads rapidly ly buds from lung, strong, underirround stcuns, which ly their viror resist the encronchunent of Bermuda grass. Once estublished it will continue to stand for a lifetimc. It is lust propagated ly euttings of the roots. 20.000 set to the acre, or say one to eacll two square fect. Roors cost alout $\$ 1.00$ jer 1000 . seed alout $\$ 3.00$ per pound. six pounds lecing sown to the acre.

These three and others will in time and lefore long be brouglt into geneal cultivation-indeel sll of our cultivited nrasses are sclections from will forms; no doult very inferior orisinally-for instance Timothy now the leading bay grass noith of the cotton Inlt, irs s fouml growing wild in the lilly or mount ninons districts ly the enrly Imerican colonists and sent to Furland in itg3. where it at once assumed the bighest rank over the four or five linds of grassea then cultivated. Indeed up to 1 slj only four or fire kinds were cultivated and it was not until the list of grasses was largely incrensed amet loot culture extended that Britisl igriculture lieman to levelop, for not till then were there increased opporti:nities for the extcnsion of grazing and the winter sulw sistence of cattle. lied Top is anoiber Imerican grass. first cultivated nbout 1760 by the colonisis. It $\pi \cdot=$ soon followed by the introduction to cultivation of Kentucky Blue grms, and subsequently Orcharl grass. It will be noticed that the United States Iurnisher four out of the five principal hay and pastumere prodncers used in arricultural practice: ?le fourth. Fial 
Clover, being a native of Asia. It cannot be doubterl, there yet rema:n others to be brought into cultivation. Who shall do it?

- Now as to compounded mixtures of grass seeds, it has been fiequently stater that seedsmen alvocate mixed grasses for lawn and pasturage that they may have an opportunity to run up the price. This is a inistake, for no pasture grass mixture is so costly as the same measure of pure Blue grass, the lack $\log$ of all good grazing mixture. Let it be understoor the object of mixing varicties of grass seeds is manifoll; for instance, to insure a more numerous stand of plants for some varieties may germinate better than others; then again that some varieties be succulent and bright when others are dingy, and for pasturage there is a very important consideration. Another good reason is that soils vary so much and seasons vary so much, that it is best in seeding clown a pasturage to diversify the risks rather than as it were to carry all the eggs in one basket.

The deliberate mixing of distinct varielies of Vegetable or Flower Seels is looked upon by all men as a fraud of the worst kind, but the intelligent mixing of distinct varieties of Grass SeEds is an art whicit should be encouraged, for, properly done, it is in the interest of agriculture's most important crop-green pasturage and hay.

Upon the length of time which it is contemplated to allow the pasturage to stand depends, to a large extent, the varieties of grass seeds to mix, as for examp'e, 'Timothy, Italian Rye grass, Cocksfoot, White and Alsike Clover are all very quick to develop and suitable for a two or three years' shift, while for a longer term should be added Blue grass, Red Top, Foxtail, Tall Fescue, Perennial Rye, Lucerne and Rerl Clover.

While the limestone soils of Kentucky and Tennessee will sustain in full vigor a pure blue grass pasturage for a life time, few soils in other localities will be found equal to the task.

On soils not suited to blue grass alone good temporary pasturage of two to five year's' duration can be obtained with a careful selection of varieties and satisfactory results realized under a well-considered system of rotation.

When one departs from the usual course of sowing Timothy with winter grain to be followed with Clover in the spring it is not a cheap matter to lay down a perfect pasture, lay field or lawn, for the preparation of the land is expensive and a combination of varieties generally more costly than the simple varieties of Timothy and Clover.

In laying down a pasture field it is best to do it in the Autumn, if conditions of moisture will permit, for the reason that time is then less precious, but Spring seeding, when the land is thoroughly prepared, is quite as effective.

All preseriptions for grass seed mixtures, however, are little more than generalities, for $n$ o one can compile a table or series of tables showing the varieties positively adapted to different localities, for soils even on adjoining fields frequently vary so much as to require an entire change in the varieties and proportions. How much more difficult to prescribe for unknown soils, some perhaps a thousand miles away.
The geological constitution, rain fall, drainage, altitude and objects souglit, whether for hay or grazing, all need to be sturlied. The lest guide is the experience of others in onc's location, but even that is often misleading, for we have grown grand crops of Timothy and Clover in a section of a Southern State, where the farmers seldom saved any hay, trusting almost entirely to corn fodder-of course there were no barnyards worthy of the name in that locality.

As an example, for ordinary soils a pasturage mixture might consist of 40 pounds to the acre of 'T'imothy, Orchard, Blne grass, Red 'Top, Perennial Rye grass, and Red Clover. Such a combination would be pretty certain to effect a stand, and when once establisher would comprehend some one variety in luxuriant growth throughout the extent of the growing season.

Of course in special locations as on lowlands or mountain sides or on special soils as sands, gravels, clays, loams, some of the named sorts might with arlvantage be omitted and others added. 'Timothy, for example, a short-lived hay grass, does best on welldrained land and in northern latitndes. Red Top, a longer-lived sort, does better on moist land, even sustaining long-continued overflow. Orchard Grass, on the other hand, a good, all-around sort, will grow on dry, sandy loam; fairly well on poor clay and better on rich bottoms, so it be not overflowed, and it even endures the shade of trees.

Blue grass doing best on limestone soils is not a good hay producer, as it is a light cropper, difficult to cut and harder to cure, but it is eminently a pasturage and lawn grass. It is an easy grower, flourishing for a limited time on gravels, bottoms and clays, while on limestone soils grazing fields have been known to remain in perfection for sixty years. It will not stand severe droughts but resists any amount of frost while continued pasturage only makes it better.

Thin seeding of grass is a most serious mistake, as a poor stand of grass only leaves room for weeds to occupy the space. Consequently we advise a very liberal application of seed, for under the best conditions, as respects preparation of land, distribution of seed and covering, a large portion of the seed will get too deeply covered over to vegetate.

Not more than one farmer in a hundred by his field practice shows any indication that he realizes the necessity of shallow covering of grass seeds, for they generally put on a harrow and cover to a depth of 1 to $2 \frac{1}{2}$ inches, delicate seeds not one-thirtieth of an inch in cliameter. Certainly the greater part never shows a green blade, for farmers seldom stop to consider the delicate nature of the seeds they commit to rough, cloddy earth. One who sets himself to estimate the number of seeds in a pound will soon come to a realization of the necessity for a perfect seed bed, for he will find the seeds to number in a pound of Tall Fescue 250,000, Red Clover 280,000, Orchard Grass 600,000, Timothy 1,250,000, Blue Grass 2,375,000, Rough Meadow $3,000,000$, and Red Top $8,000,000$. Can it be expected that over ten per cent. of the seeds ever make a plant, considering the rough tillage and careless sowing of the ordinary farmer? 


\section{TABLE SHOWING THE NUMBER OF PLANTS REQUIBED PEB ACBE AT GIVEN DISTANCES.}

\begin{tabular}{|c|c|c|c|c|c|c|c|c|c|c|c|c|c|c|c|c|c|c|c|c|c|c|c|}
\hline Feet & In. & & Feet. & In. & Plants. & Fect. & In. & & Feet. & In. & Plants. & Feet. & In. & & Feet. & In. & Plants. & Feet. & In. & & Feet. & In. & Plasis. \\
\hline 9 & & by & 9 & & 537 & 5 & 6 & by & 3 & 9 & 2,112 & 4 & G & by & 2 & & $\{, \varepsilon 40$ & 3 & 3 & by & 3 & 3 & 4,124 \\
\hline 9 & & it & 8 & & 605 & 5 & 6 & it & 3 & 6 & 2,262 & 4 & 8 & .8 & 1 & 9 & $5,5,31$ & 3 & 3 & ii & 3 & & 4,819 \\
\hline 9 & & " & 7 & & 691 & 5 & 6 & "1 & 3 & 3 & 2,436 & 4 & 6 & $"$ & 1 & B & 6,403 & 3 & 3 & " & 2 & 9 & 4,873 \\
\hline 9 & & " & 6 & & 806 & 5 & 6 & $" 1$ & 3 & & $2, f ; 40$ & 4 & 6 & " & 1 & 3 & 7,744 & 3 & 3 & $"$ & 2 & G & $5,3 P 1$ \\
\hline 9 & & " & 5 & & 968 & 5 & 6 & $"$ & 2 & 9 & $2,8 \times 6$ & 4 & 6) & $"$ & 1 & & 9,$1 ; 80$ & 3 & 3 & " & 2 & 3 & $5,8.553$ \\
\hline 8 & & $" 1$ & 8 & & 680 & 5 & f & $" 1$ & 2 & f) & $3,1 f 8$ & 4 & 2 & $" 1$ & 4 & 3 & 2,411 & 3 & 3 & "“ & 2 & & 6,701 \\
\hline 8 & & " & 7 & & 777 & 5 & 6 & $" 1$ & 2 & 3 & 3,520 & 4 & 3 & “" & 4 & & 2,$5 ; 2$ & 3 & 3 & “ & 1 & 9 & 7,058 \\
\hline 8 & & $" 1$ & 6 & & 905 & 5 & 6 & "1 & 2 & & 3,9600 & 4 & 3 & "“ & 3 & 9 & $2,73.3$ & 3 & 3 & " & 1 & 6 & 8,935 \\
\hline 8 & & "1 & 5 & & 1,089 & 5 & 6) & "1 & 1 & 9 & 4,525 & 4 & 3 & "1 & 3 & $\varepsilon$ & 2,314 & 3 & 3 & "1 & 1 & 3 & 10,722 \\
\hline 8 & & $" 1$ & 4 & & 1,361 & 5 & 6 & $"$ & 1 & 6 & 5,280 & 1 & 3 & " & 3 & 3 & 3,153 & 3 & 3 & "1 & 1 & & 13,403 \\
\hline 8 & & $"$ & 3 & & 1,815 & 5 & 6 & " & 1 & 3 & 6,3336 & 4 & 3 & " & 3 & & 3,416 & 3 & & 6: & 3 & & 4.540 \\
\hline 7 & & $"$ " & 7 & & 888 & 5 & 6 & " & 1 & & -910 & 4 & 3 & " & 2 & 9 & $3,7 \div 7$ & 3 & & " & 2 & 9 & 5,259 \\
\hline 7 & & " & 6 & 6 & 957 & 5 & & " & 5 & & 1,742 & 4 & 3 & " & 2 & $e$ & 4,099 & 3 & & " & 2 & 6 & 5,808 \\
\hline 7 & & $"$ & 6. & & 1,037 & 5 & & " & 4 & 9 & $1,8.34$ & 4 & 3 & " & 2 & 3 & 4, 505 & 3 & & $"$ & 2 & 3 & $6,4: 33$ \\
\hline 7 & & $"$ & 5 & B & 1,131 & 5 & & " & 4 & 6 & $1,93 \%$ & 4 & 3 & " & 2 & & 5,124 & 3 & & $"$ & 2 & & -3.250 \\
\hline 7 & & " & $\Delta$ & & 1,244 & 5 & & $"$ & 4 & 3 & 2,049 & 4 & 3 & $"$ & 1 & 9 & $5, x=8$ & 3 & & " & 1 & 9 & 8,297 \\
\hline 7 & & $"$ & 4 & 6 & 1,382 & 5 & & $" 1$ & 4 & & 2,178 & 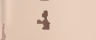 & 3 & “ & 1 & 6 & 6,832 & 3 & & “ & 1 & B & 8,650 \\
\hline 7 & & $"$ & 4 & & 1,555 & 5 & & " & 3 & 9 & 2,323 & \pm & 3 & " & 1 & 3 & 8,193 & 3 & & $" 1$ & 1 & 3 & $11,6,16$ \\
\hline 7 & & " & 3 & 6 & 1,777 & 5 & & $"$ " & 3 & 6 & $2,-189$ & 4 & 3 & " & 1 & & 10,249 & 3 & & $" 1$ & 1 & & 14,520 \\
\hline 7 & & $"$ & 3 & & 2,074 & 5 & & "1 & 3 & 3 & 2,1580 & 4 & & $"$ & 4 & & $2,-2: 2$ & 2 & 9 & $" 1$ & 2 & 9 & $\therefore, \pi, 0$ \\
\hline 7 & & $"$ & 2 & 6 & 2,489 & 5 & & $" 1$ & 3 & & $2,(4) 4$ & 4 & & " & 3 & 9 & 2,904 & 2 & 9 & “ & 2 & if & $6.3 \%$ \\
\hline 7 & & $"$ & 2 & & 3,111 & 5 & & $" 1$ & 2 & 2 & $3,18,9$ & 4 & & " & 3 & 6 & 3,111 & $\because$ & 9 & “ & 2 & 3 & $7,0 \pm 0$ \\
\hline 7 & & " & 1 & 6 & $\$, 148$ & " & & $" 1$ & 2 & 6 & $3,48:$ & 4 & & “ & 3 & 3 & $3,3: 0)$ & 2 & 9 & " & 2 & & 7,820 \\
\hline 7 & & “ & 1 & & fi,223 & 5 & & $"$ & 2 & 3 & 3,874 & 4 & & " & 3 & & 3,030 & 2 & 4 & " & 1 & $\theta$ & 8,054 \\
\hline 6 & 6 & " & 6 & 6 & 1,031 & 5 & & " & ב & & $\$, 356$ & 4 & & "1 & 2 & 9 & $3,14 \div 0$ & 2 & 9 & “ & 1 & e & 10,80 \\
\hline 5 & 6 & $" 1$ & 6 & & 1,110 & 5 & & “" & 1 & 9 & 4,078 & 4 & & $" 1$ & 2 & 6 & 4,3510 & 2 & 9 & " & 1 & 3 & 12,650 \\
\hline (j & 6 & "1 & 5 & 6 & 1,218 & 5 & & " & 1 & 6 & 5,808 & 4 & & " & 2 & 3 & $4 \times 40$ & $\because$ & 9 & $\because$ & 1 & & $13, \leq 10$ \\
\hline 6 & (j) & " & 5 & & 1,340 & 5 & & $" 1$ & 1 & 3 & $6,9 M: 8$ & 4 & & " & 3 & & $5 .+15$ & 2 & 6 & ". & 2 & $f$ & $r i, g r i 0$ \\
\hline 6 & 6 & " & 4 & 6 & $1,+840$ & 5 & & "1 & 1 & & 8,712 & 4 & & “ & 1 & 9 & $6, x=2$ & 2 & fi & 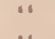 & $\because$ & 3 & $i, 740$ \\
\hline 6 & 6 & $" 1$ & 4 & & $1,67 \mathrm{~s}$ & 4 & 3 & $" 1$ & 4 & 9 & $1,4: 30$ & 4 & & " & 1 & 6 & - 2800 & 2 & fi & ". & 2 & & 8.743 \\
\hline 6 & 6 & $" 1$ & 3 & 6 & $1,: 114$ & 4 & 9 & $" 1$ & 4 & B & 2,1137 & 4 & & “ & 1 & 3 & 6,712 & 2 & f & " & 1 & 6 & $9.9: 8$ \\
\hline 6 & 6 & "1 & 3 & & 2,233 & 4 & ! & “ & 4 & 3 & 2,157 & 4 & & "̈ & 1 & & $10,5: 4$ & 2 & 6 & .6 & 1 & ii & 11,616 \\
\hline 6 & 6 & “" & 3 & 6 & 2,680 & 4 & 9 & " & 4 & & $2,-4,2$ & 3 & 9 & "“ & 3 & 9 & $3,\left(x_{1} 7\right.$ & 2 & 6 & 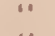 & 1 & 3 & 13,039 \\
\hline 6 & 6 & " & 2 & & 3,350 & 4 & (8) & " & 3 & 9 & $\because, 445$ & 3 & 9 & “ & 3 & 6 & $3,31 / \mathrm{A}$ & 2 & B & " & 1 & & 17.424 \\
\hline 6 & 6 & $" 1$ & 1 & 6 & 4,418 & 4 & 9 & " & 3 & i) & $2,6: 0$ & 3 & $!$ & 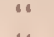 & 3 & 3 & $3, \therefore 74$ & 2 & 3 & " & 2 & 3 & Sint \\
\hline f) & .6 & 14 & 1 & & 6,701 & 4 & 9 & “ & 3 & 3 & $\because 821$ & 3 & $?$ & $"$ & 3 & & $3.5 \% 2$ & 2 & 3 & 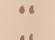 & 2 & & $\because, 6 \leq 0$ \\
\hline$\theta$ & & $"$ & 6 & & 1,210 & 4 & 9 & ". & 3 & & $3,(1,5 f)$ & 3 & 4 & 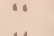 & 3 & $?$ & +24 & 2 & 3 & " & 1 & $?$ & $11, t m: 2$ \\
\hline 6 & & $" 1$ & 5 & 9 & 1,268 & \pm & 9 & " & 2 & 9 & 3,334 & 3 & $!$ & $"$ " & 2 & 6 & $4,+146$ & 2 & 3 & $"$ & 1 & 6 & 12.815 \\
\hline 6 & & " & 5 & 6 & 1,320 & 4 & 9 & “" & 3 & (j) & $3,60,3$ & 3 & $?$ & " & 2 & 5 & $3.18: 2$ & 2 & 3 & " & 1 & 3 & 17,468 \\
\hline 6 & & " & 5 & & $1,+53$ & 4 & $!$ & " & 3 & 3 & +0.5 & 3 & 9 & 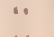 & 2 & & 5,418 & 2 & 9 & $" 6$ & 1 & & $18.3 \mathrm{nO}$ \\
\hline 6 & & " & 4 & 6 & 1,613 & 4 & 9 & " & 3 & & t.ins. & 3 & 9 & “ & 1 & 9 & 6,637 & $=$ & & " & 2 & & 10,5 \\
\hline 6 & & $"$ & 4 & & 1,815 & 4 & 9 & " & 1 & $?$ & $5,24 k$ & 3 & $\because$ & 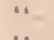 & 1 & 6 & $\because 744$ & 2 & & “" & 1 & $?$ & 12.445 \\
\hline 6 & & " & 3 & 6 & 2,074 & 4 & 9 & " & 1 & 6 & 6,113 & 3 & $!$ & 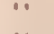 & 1 & 3 & $\because 12 \% 2$ & 3 & & 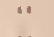 & 1 & 6 & $14,5=0$ \\
\hline 6 & 1 & " & 3 & & 2,420 & 4 & 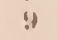 & " & i & 3 & -3.333 & 3 & $\vdots$ & $\ddot{\prime}$ & 1 & & $14,610^{\circ}$ & 2 & & 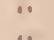 & 3 & 3 & $17,4 \geq$ \\
\hline (i) & & " & 2 & 6 & 2,901 & 4 & $\because$ & " & 1 & & $\because 1,101)$ & 3 & f. & " & 3 & 6 & 3. & 2 & & ". & 1 & & $21 . ; \infty]$ \\
\hline (i) & & " & 2 & & 3,0330 & 4 & 6 & “ & 4 & 6 & 2,151 & 3 & ii & " & 3 & 3 & $3 .=0$ & 1 & 9 & 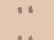 & 1 & 8 & $14, \approx 23$ \\
\hline 6 & & " & 1 & o & 4,840 & 4 & ii & “ & 4 & 3 & 2,278 & 3 & $n$ & $"$ & 3 & & 4,145 & 1 & $?$ & 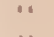 & 1 & 6 & 16,84 \\
\hline 6 & & ."1 & 1 & & 7,260 & 4 & 6 & “ & $i$ & & $2,4 \geq 0$ & 3 & i & " & 2 & 9 & 4,505 & 1 & 4 & 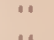 & 1 & 3 & 119,913 \\
\hline 5 & 6 & " & 5 & 6 & $1,41 i$ & 4 & 6 & " & 3 & 9 & $2, \therefore-1$ & 3 & i) & " & $\because$ & 6 & 4.978 & 1 & 9 & “ & 1 & & $=4,4 \div$ \\
\hline 5 & 6 & " & 5 & 3 & 1,508 & $i$ & i & “ & 3 & i & ?itain & 8 & fi & " & $\because$ & 3 & $\therefore 5.31$ & 1 & B & . & 1 & ii & 19,360 \\
\hline 5 & ii & " & 5 & & 1,584 & 4 & 6 & “" & 3 & 3 & 2,973 & $:$ & 6 & "6 & $\because$ & & di, $2=2$ & 1 & 6 & " & 1 & 3 & 23,232 \\
\hline 5 & (i) & $" 1$ & 4 & 8 & 1,603 & 4 & 6 & " & 3 & & 3,$221 ;$ & 3 & ii & “ & 1 & $?$ & -111 & 1 & ii & $"$ & 1 & & $-8,1140$ \\
\hline 5 & 6 & " & 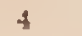 & 6 & 1,760 & 4 & 6 & $"$ & 2 & 9 & $3,5: 00$ & 3 & fi & 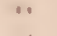 & 1 & 6 & $\because 210$ & 1 & 3 & ". & 1 & 3 & $\because, \cdots=$ \\
\hline 5 & 6 & " & 4 & 3 & $1,80: 3$ & 4 & (i) & " & 2 & 6 & $3,5,2$ & 3 & i & " & 1 & 3 & 4.918 & 1 & 3 & .6 & 1 & & is, is \\
\hline 5 & 6 & " & 4 & & 1,980 & 4 & 0 & " & 2 & 3 & 4,302 & 3 & 6 & ". & 1 & & 12,445 & 1 & & " & 1 & & $+3,30$ \\
\hline
\end{tabular}

\section{PLOWING.}

Long lanis are much to be preforecil to short felold, an much tine ia ared in turnlag. aub In hericultural operutious thue to everjthing.

EXPLATATION.

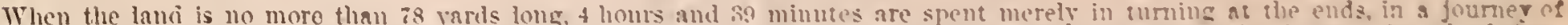

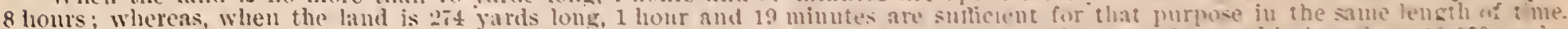

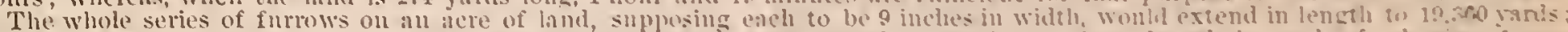

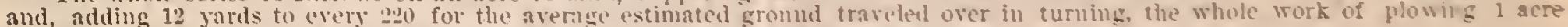
may be given is extending to 20,416 yands, or 11 miles and nearly so furlong:

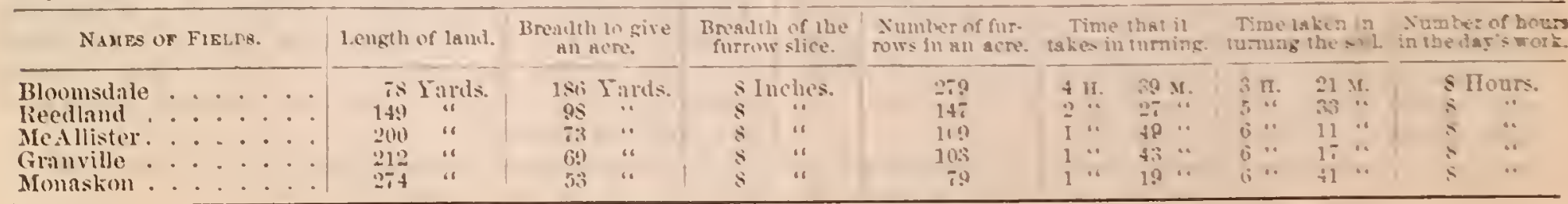




\section{TABLE, SHOWING THE COMPARATIVE DIFFERENCE BETWEEN GOOD HAY AND THE ARTICLES MENTIONED BELOW, AS FOQD FOB STOCK, BEING THE MEAN OF EXPERIMENT AND THEORY.}

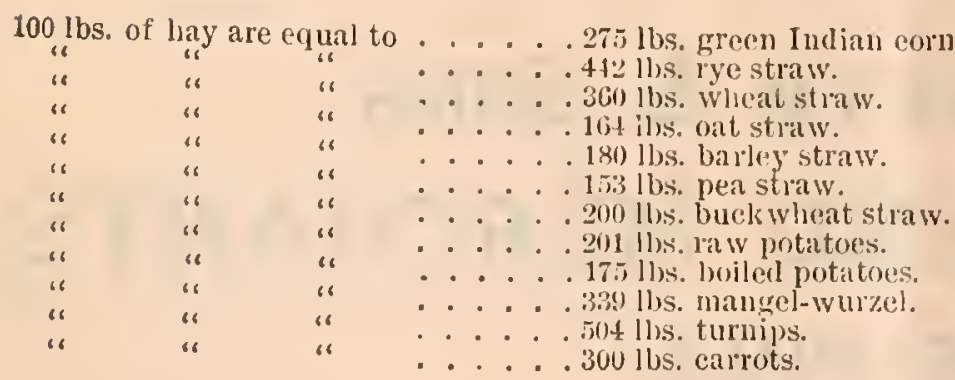

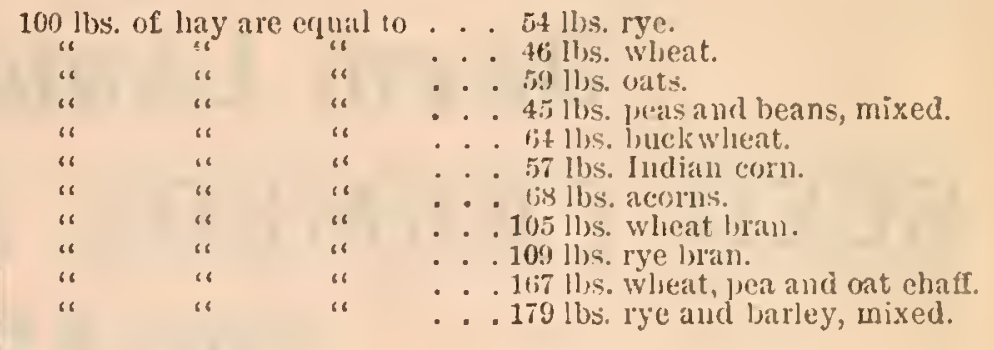

\section{MEASUREMENT OF CORN IN THE CRIB.}

After levelirg the Corn, multiply the length and brearth of the hoise together, and the product by the depth, which will give the cubie feet of the bulk of Corn; then divide this last produet by 12 , ind the quotient will be the number of barrels of sheller Corn contained in the house or crib. If there be a remainder after the division, it will be so many tivelfths of a barrel of shelled Corn over.

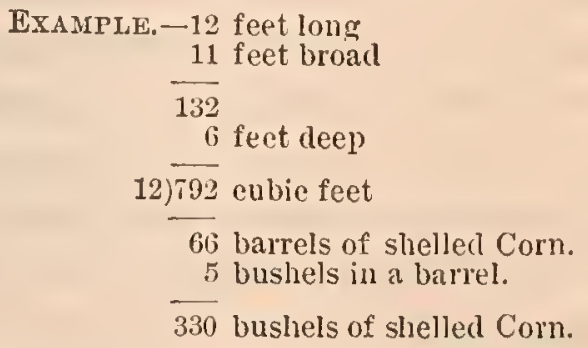

Memoranda.-21,500 cubic inches will contain ten bushels of shelled Corn, but the same space filled with Corn in the ear will shell out rather more than five buslicls. These 21,500 cubic inches contan 12 cubic feet and 764 cubic inches over. Now two barrels, or ten bushels in the ear, will generally, in shelling, overru just about these 604 cubic inches.

$\overline{330}$ bushels of shelled Corn.

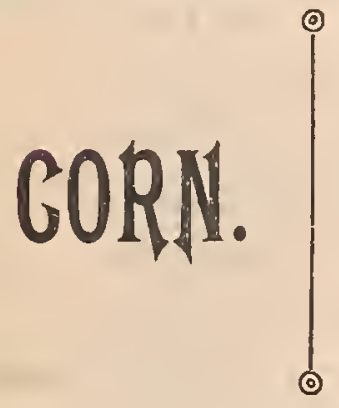

\section{Southern Roasting Ear.}

A short-stalked, strong-foliaged, vigorous rooting variety of table Corn adapted to the Southern climate, being less liable to insect injury and the burning effects of hot sun than the more delicate sugar varieties.

Grain white, swcet, productive in good ears. A sort which solves the problem of $a$ valuable roasting ear for planting in the Southern States.

An excellent variety for trucker's' use for Northern shipment.

Plits. 5c. and 10c.; per qt. 20c.; per $\frac{1}{4}$ bush. $\$ 1.00$; per bush. $\$ 3.15$.

\section{Landreths' Extra Early Peas}

HAVE A WORLD-WIDE REPUTATION.

We have testimony of their extreme earliness, productiveness, superior quality, and adaptability to the various soils in which they were planted, from

ENGLAND. $\left\{\begin{array}{c}\text { Worcester, } \\ \text { Witham, } \\ \text { Chester, } \\ \text { Maidstone, } \\ \text { Bedford. }\end{array}\right.$
FRANCE. $\left\{\begin{array}{c}\text { Béziers, } \\ \text { St. Remy, } \\ \text { Nantes. }\end{array}\right.$

GERMANY. $\left\{\begin{array}{c}\text { Frankfurt } \% / M, \\ \text { Leipsic, } \\ \text { Quedlinburg. }\end{array}\right.$

HOLLAND. \{Enkhuizen.

SWEDEN. $\left\{\begin{array}{r}\text { Stocizholm, } \\ \text { Albano. }\end{array}\right.$ 


\section{DAYID LANDRETH \& SONS,}

\section{SEED FARMERS AND MERCHANTS, PHILADELPHIA.}

1784

1786

Chia. About 1786 he issociated his brothe Cuthbert in the business of seed and tree enlture. The first place of business was on Mighl Street, the exnet position now being covered by the buildings 1210 and 1212 Market Street, then a location well ont in the comntry. Contiguous land was rented for nursery and seed growing purposes, the lingest section being a tract at the intersection of Twelfth and Fillert Streets.

The original firm designation was navid Landreth. The Landreth nursery and seed garden in the "Neck," a long and nalrow tongne of land lying betreen the Delanare and Sehuylkill rivers on the sonth of Philatelplia, 1789 was established in 1759 on rented land. The following year a portion of the tract was purclased, and an reljoining traet purehased in 1798.

1798 In 1795 the firm title was David of Cuthbert Landreth. The first partner resided at 'Twelfth and Market Strects, at which place David Landreth, Jr., was borm, in 1802. The other partner lived at the musery. The old mansion house on the luursery grouml- a roomy building, which was in time enturrered in rines and so surrounded by rave bluph and trees as to become one of the show plates of I'hiladelphis. was, in 1847, sold to the School lioard of Philadelphia, and altered to mect the requirements of public education. It was de-irnated as the Landreth School. sub-equently burned and a new building prected.

From the Lamdreth uurecries were dram many of the matured specimens of fine trees which now embellish the old country-seats around Philadelphia. Fine examples of these trees are to be seen in the oldest ashes, elms, lirehes. oaks, and butonwoods of Wralington and Independence Syuares, these being planted about the begimning of the century. In 1 sos David of Cuthbert Lanulreth coudneted business at three locations-nt the seed store on Market Street near Twelfh Street; at the southeast cormer of the old Court-honse: at the unrsery, near the Lnited States ArEenal. Aliout 1810 a seed store wa establisherl on Second Street, belom llarket. In 1418 a branch was established in Charlestoun. S. C. Sulisequently. the property Xos. 351 such 393 King street was purebased, and the husiness continned until the real estate and merehandise were contis"ater. April 2. 1862. by order of the District Count of the Conterate States. 
In 1820 a tract was purchisserl and used as a seed farm on Fifth Street below Fedcral. The mansion louse on this tract was lnilt in Colonial style, and, surrounded by many fine trees of pinc and linden, was widely known as "Garlic Hall," so named after an old Winglish estate.

Shortly subsequent to 1820 , the premises then No. 85 Chestnut Street were occupied as a seed store, afterwards remover to No. 83, and again to No. 65, which latter location was purchased in 1852, when an iron and brick warehouse, large for that day, was erected and occupied, its present number being 221.

1828 In 1828 David Landretl, .J r., and Thomas Landreth, son of Cuthbert, took t!e business from their respective father's, David, Jr., taking the seed department, and Thomas, the nursery.

1836 In 1836 the title was David Landreth \& Co., the firm consisting of David Landreth, Jr., Thomas Landreth, and J. W. Burrows.

David Landreth, 1st, died in 1836.

1839 In 1837 Thomas Landreth reconvered the nursery to David Landreth, $J_{r}$., and the seed and nursery branches were again mnited.

1843 In 1843 the title of the firm was David Lan. dreth \& Darid Landreth Munns.

1845 In 1845 the firm title Was David Landreth, Seedsman, and Darid Landretl \& Fulton, Nurserymen.

1848 In 1847 Bloomsdalc farm, Bristol, Pa., was purchased and deroted to seed crops. This tract consists of 500 acres, with several auxiliary tracts in other States.

1848 In 1848 Darid Landreth, $\mathrm{J} r$, , sold the nursery to James D. Fulton, retaining the more important seed division.

1853 In 1853 the premises Nos. 21 and 23 South Sixth Street were purchased, and a warehouse built, since occupied as a seed store. At this date there was established at Bristol, Pa., a factory for making nowing and reaping machinery, hay rakes, and power corn shellers.
In 1854 a branch seed store was establisherl at St. Louis, Mo., and continued six or seven year's.

In 1860 the firm title was changed to D. I andreth \& Son, by the entry of $\mathrm{Mr}$. Oliver Laind reth.

In 1876 the title of the firm was again clianged to David Iandreth of Sons.

In 1880 Darid Iandreth, 2d, died. He was an agricnlturist of rare experience and ability - a rapud, pleasing writer on rural topics. In 1827 he was one of the founders, and in 1828 , and the seven years following, the Correspondin Secretary of the Pennsylvania Horticultural Society, the mother of all similar societies in the United States.

In 1856 lie was chosen President of the Philadelphia Agriculturai Society, founded 1785, from which sprung every other agricultural society in the nation. He was Vice-President of the United States A gricultural Society, and an active member of a number of similar organizations. His firm was one of the first manufacturers of mowing and reaping machines in the United States. In 1871 and 1872 they made thorough experiments in steam-plowing by direct traction, and in 1885 in steam-digging, and subsequently in steam-chopping. Extensive forest planting in Virginia was undertaken by the firm in 1872, and has since been continuously conducted.

The business is carried on under the title adopted in 1876, the partners being Oliver Landreth, Burnet Landreth, Leopold Landreth. It is that of growing and selling field, vegetable, and flower seeds, in both domestic and foreign markets.

Nany of the employees of the firm have been with it for a life-time, and anong its customers are hundrecis for fifty years and many for a longer period; Leadbenter \& Co., of Alexandria, Ta, have been annual wholesale purchasers of Landreths' seeds since the yenr 1792. Washington was a purchaser of Landreths' seeds.
1854

1860

1876

1880 


\section{COLORED ILLUSTRATIONS AND DIRECTIONS FOR PLANTING ON EACH PACKET. \\ Liandreths' Flowver Seeds}

VARIETIES MARKED ANNUAL, BLOOM THE FIRST SEASON AND DIE.

VARIETIES MARKED BIENNIAL, BLOOM THE SECOND SEASON AND DIE.

VARIETIES MARKED PERENNIAL, LAST SEVERAL YEARS, BLOOMING EACH SEASON, EXCEPT THE FIRST.

SELECT FROM THE FOLLOWING LIST THE VARIETIES YOU FANCY, AVD WITH THE ORDER REMIT US THE PRICE FOR EACH PAPER DESIRED. THE MONEY CAN BE SENT AS A BANK-NOTE, A POST-OFFICE ORDER, OR A FOSTAL NOTE.
POSTAGE FREE. PRICES AS INDICATED.

NOTICE REMARKS ON EACH PACKET AS TO DEPTH OF COVERING.

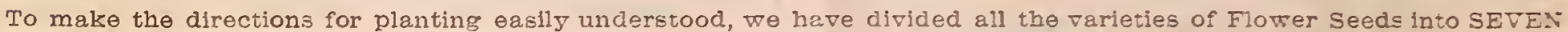

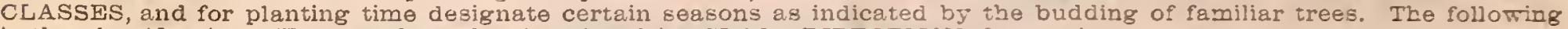
is the classification. Upon each packet is printed its CLASS DIRECTIONS IOr EOWing:

Ist Class.-Sow under glass early in Spring (before the Peach

tarted into bloom), and transplant into small pots, to be turned out at the proper season; or sow latler end of Spring (when the Oak and other late trecs put forth), in a slieltered sunny comparment of the garseed covcred not cxceeding three or four times its dismeter. Thin out and transplant in damp weather to proper pos

$2 d$ Class. - Sow early in Spring (when the peach comes into bioom), or still better in the Autumn immediately after the heat of Sumner. Let the bed be deeply clug, and raked into the finest tilth, and the seed covered not exceeding three or four times its diameter. Sheler during Winter with straw, or other light material.

3d Class.-Sow as car!y in the Spring as the eartl will permit (isually when the Applc and Cherry are blooming). Lrat the bed be deeply dug, and raked into the finest tilth, and the seed covered not crceeding three limes its diameter. Thin out and sransplant in damp weather to proper positions.

\section{FORCING OR STARTING SEEDS IN THE HOUSE.}

When it is desircd to hasten the development of plants, they mat. greenhouses hardly need directions, but for those who have had less exper bake and become sour. Seeds will uot germinate sausficluril th or thrive in a

Prepare a mixture of onc-third lenf-mold cut fine, ont-ilitel clean sand. oughly, and fill into the boxes to within a half-incly of the top-genelp patting out of sight, by sifting over the seed the finest dust procurable, settling the cation baking the surface.

Place the

When the Seedlings are half an inch high, these become so large is 10 crowd eacli other, 4th Class. - Sow latler end of Spring (when the Oak and other trec l.ave put forti. in a sheliered comparment of the garcen.

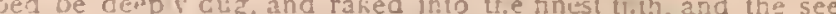
ered not exceeding tinee or four times its diameter. Thin out and 5th Class. - Sow latler end of Spring (when the Oair and other trees have put forth, in those positiors where it is desired the plants uld rem.in. Iot the beds be deen y d'rg, and raked into the finest , and the seed cosered $n$ i exceeding ihree or four bimes its diameier. Gth Class.-Al luter end of Spring (when the Oak and othe: Grees Di: lorth solk the seed I r ten or fifteen hours in tep d waer. solv in those positions where it is desired the piant or plants should

Fth Class. - Sow in Au:umn, or eary linin:er, in the greenhouse

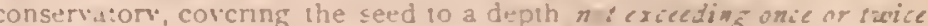
diwneler-beller perhape $n$ i c ler at ... When the plaris tave ached a surtable size, prick out in the usual manner.

\section{OPEN-AIR CULTURE.}

Flower secds being usually small and delicate, the land to receive them nu-t necr- irll be carefully prep red, c: erwise :he cost c: nu-chase a...

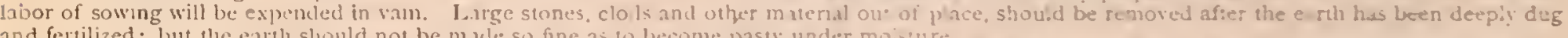
and fertilized; but the earth slould not be m.xeles

The best results will generally be obtained

in in the conserviory or $n$ boves with $n$ ihe house. Those who hase ep. The bottoms open for the free passage of wa:er, ese the earth wht? and one-thisd fincly pulver.zed stal'e manure, mosten the mix:ure thorown the stuface to a leve!. Lo $n$th is d - : bute tle seed and cive: jus: 0 and $0^{0}$. applying wa:er w.th a liresh o: fine rose when the sarface round, wh

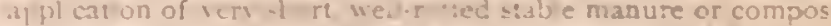

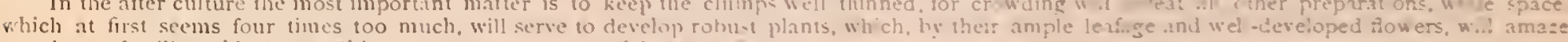
people not familiar with the conditions necessiry w succesful plant cu ture.

\begin{tabular}{|c|c|c|c|}
\hline 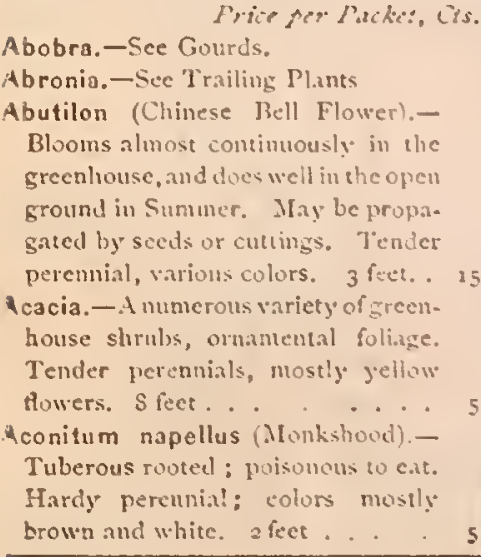 & 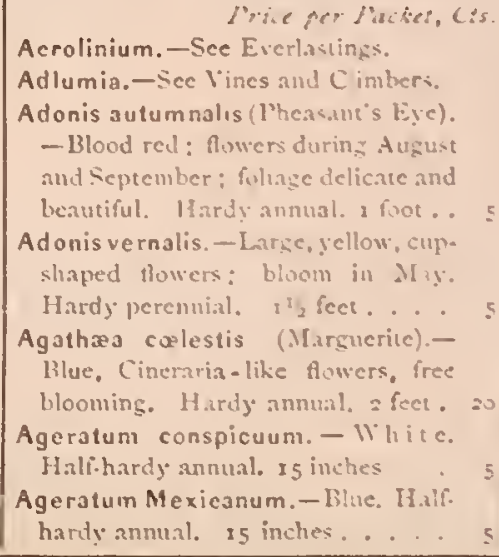 & 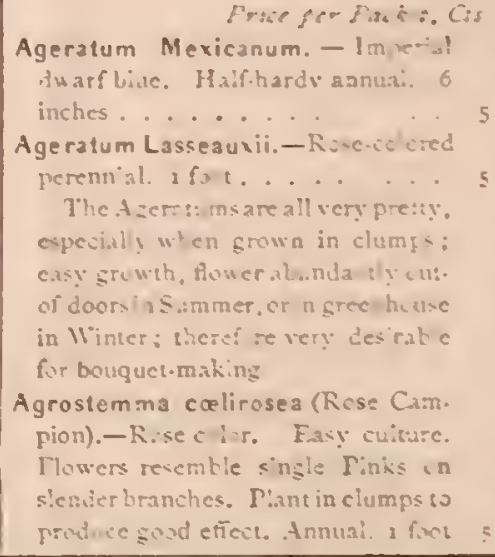 & 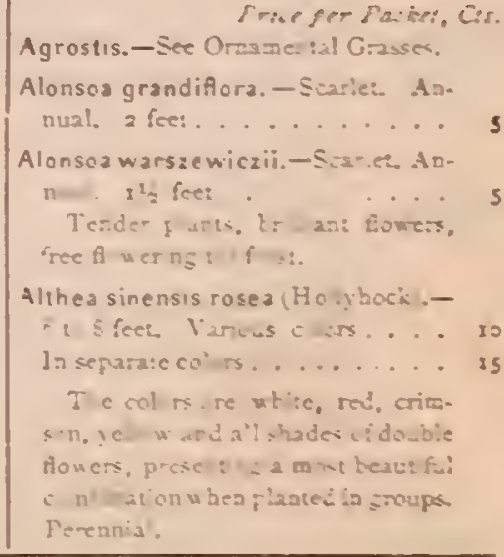 \\
\hline
\end{tabular}



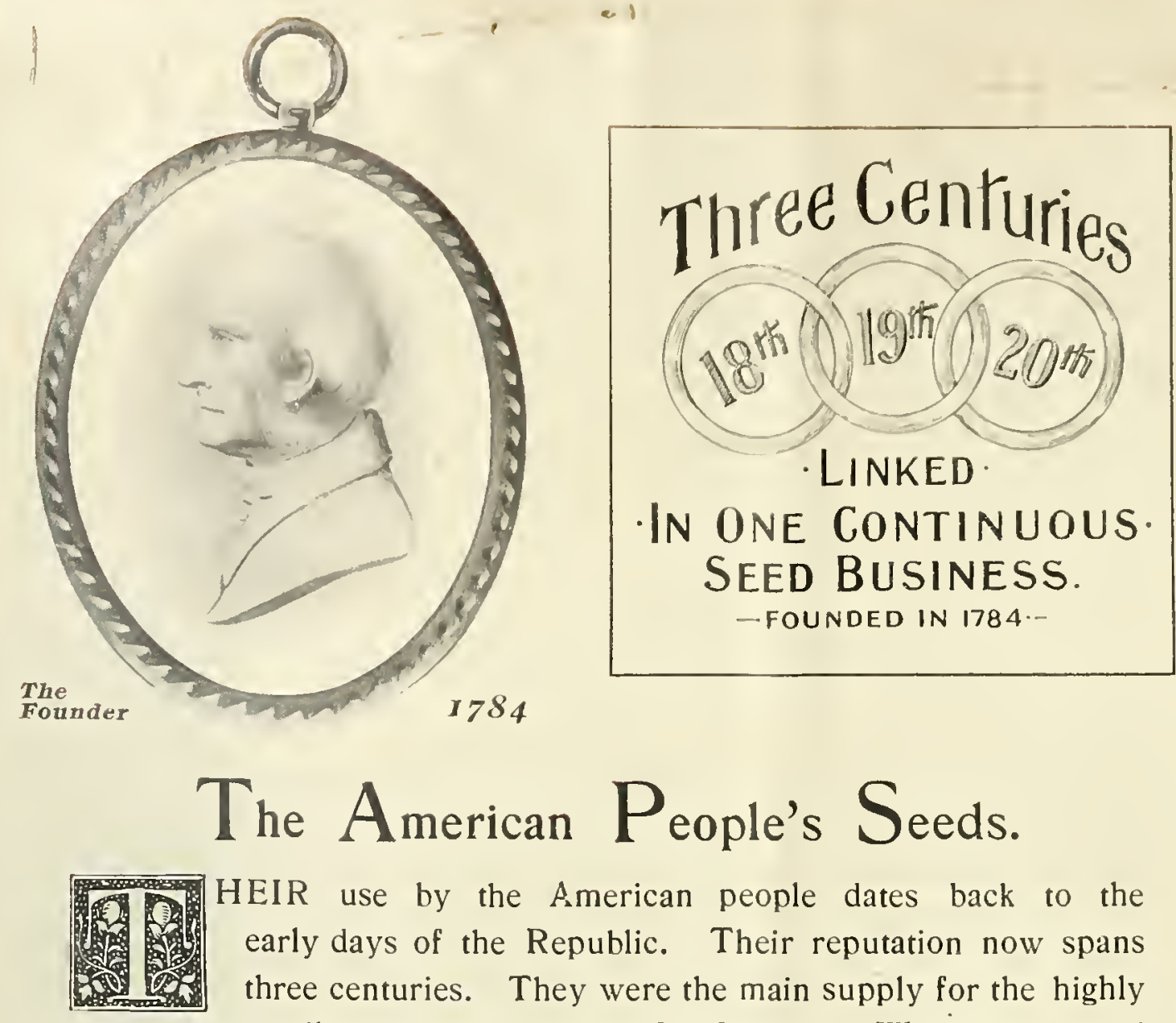

\section{The American People's Seeds.}

HEIR use by the American people dates back to the early days of the Republic. Their reputation now spans three centuries. They were the main supply for the highly extolled gardens of our forefathers. Washington used Landreths' Seeds at Mount Vernon, and Jefferson at Monticello. * *

\section{David Landreth \& SONS}

\section{Seed Farmers and Merchants}

\section{Philadelphia}

\section{4}

The Landreth Nursery and Seed business was established in Philadelphia in 1784. Its founder was David Landreth, born 1752, near Berwick-on-Tweed, son of a Northumberland farmer, who had, in England, applied himself to the business of tree growing. He emigrated to Canada in 1781, shortly after removing to Philadelphia. About 1786 he associated his brother Cuthbert in the business of seed and tree culture. The first place of business was on High Street, the exact position now being covered by the buildings 1210 and 1212 Market Street, then a location well out in the country. Contiguous land was rented for Nursery and Seed Growing purposes, the largest section being a tract at the intersection of Twelfth and Filbert Streets. 



\title{
The Landreth Seed Establishment
}

SINCE ITS FOUNDATION, IN 1784

\section{Various Locations of Their Labors:}

ON SEED FARMS. Ystablished Arch Street, Pliladelphia . . . I 784

Federal Street, Garlic Hall, The Meadows, Fifth Street, Gray's Ferry, Bloomsdale, Bucks Co., Pa. . . . I 847 Reedland, New Jersey . . . . . . 1865 Monaskon, Virginia .. . . 1871 Granville, Virginia . . . . I87 I Manitowoc, Wisconsin . . . . 1873
AT SEED STORES. $\begin{gathered}\text { rear } \\ \text { Established }\end{gathered}$ Market Street, Philadclplia . . 1784 Federal Street, “ ، . . I789 Old Court House, " " . . I790 Second Street, " . . 1810 Charleston, South Carolina . . . I8I8 Chestnut Street, Philadelphia . I I 820 Sixth Street, “ _. . I853 St. Louis, Missouri . . . . I 1854 Arch Street, Philadelphia . . ${ }_{1} 878$ Market Street, “ _. . . 1898 Jan1aica, Long Island, N. Y. . . . 1899

\section{$* 2 *$}

\section{...BUSINESS ESTABLISHED...}

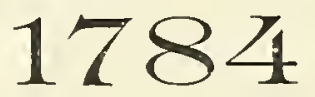

\section{VARIOUS FIRM TITLES}

\author{
DAYID LANDRETH, I 794 \\ DAVID \& CUTHBERT LANDRETH, I 790 \\ DAVID LANDRETH \& CO., I 830 \\ DAVID LANDRETH AND D. LANDRETH MUNNS, 1343 \\ DAVID LANDRETH, I 845 \\ DAVID LANDRETH \& SON, I860 \\ DAVID LANDRETH \& SONS, I 875
}

The Firm designation of 1875 is still continued.

The Landreths at present engaged in the business are Burnet Landreth, Leopold Landreth, Wm. Linton Landreth, Burnet Landreth. Jr. and S. Phillips Landreth. 



\section{ROSTER}

OF SOME OF THE BUILDERS OF

\section{The Landreth Seed Establishment}

SINCE ITS FOUNDATION, IN 1784

\section{Various Locations of Their Labors:}

ON SEED FARMS. $\begin{gathered}\text { Year } \\ \text { Established }\end{gathered}$ Arch Street, Philadelphia . . . I784

Federal Street,

Garlic Hall,

The Meadows,

Fifth Street,

Gray's Ferry,

Bloomsdale, Bucks Co , Pa. . . . I 847

Reedland, New Jersey . . . . I865

Monaskon, Virginia .. . . 1874

Granville, Virginia . . . . I $\$ 7$ I

Manitowoc, Wisconsin
AT SEED STORES. Estabilshed Market Street, I'hiladılphia . . 1784

Federal Street, " . . I 789

Old Court House, " " . . 1790

Second Street, “ _. 1810

Cliarleston, South Carolina . . 1818

Chestnut Street, Philadelphia . . 1820

Sixth Strect, “ . . I 853

St. Lounis, Missouri . . . . 1854

Arch Street, Philadelphia . . 1878

Market Street, " _. . 1898

Jamaica, I,ong Island, N. Y”. . . . I899

\section{$2+2$}

\section{...BUSINESS ESTABLISHED...}

1784

\section{VARIOUS FIRM TITLES}

DAVID IANDRETH, I 784

DAVID \& CUTHBER'T LANDRETH, I 790

DAVID LANDRETH \& CO., I830

DAVID LANDRE'TH AND D. LANDRETH MUNNS, I 843

DAVID LANDRETH, I 845

DAVID I,ANDRE'TH \& SON, I 860

DAVID LANDRETH \& SONS, I875

The Firm designation of 1875 is still continued.

The Landreths at present engaged in the business are Burnet Landreth, Leopold Landreth, Wm. Linton Landreth, Burnet Landreth: Jr. and S. Phillips Landreth. 




\section{EIGHTY-FIVE WORKERS OF OVER TWENTY-FIVE YEARS OF SERVICE.}

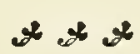

Those marked* are yet on the Rolls, January, 1901.

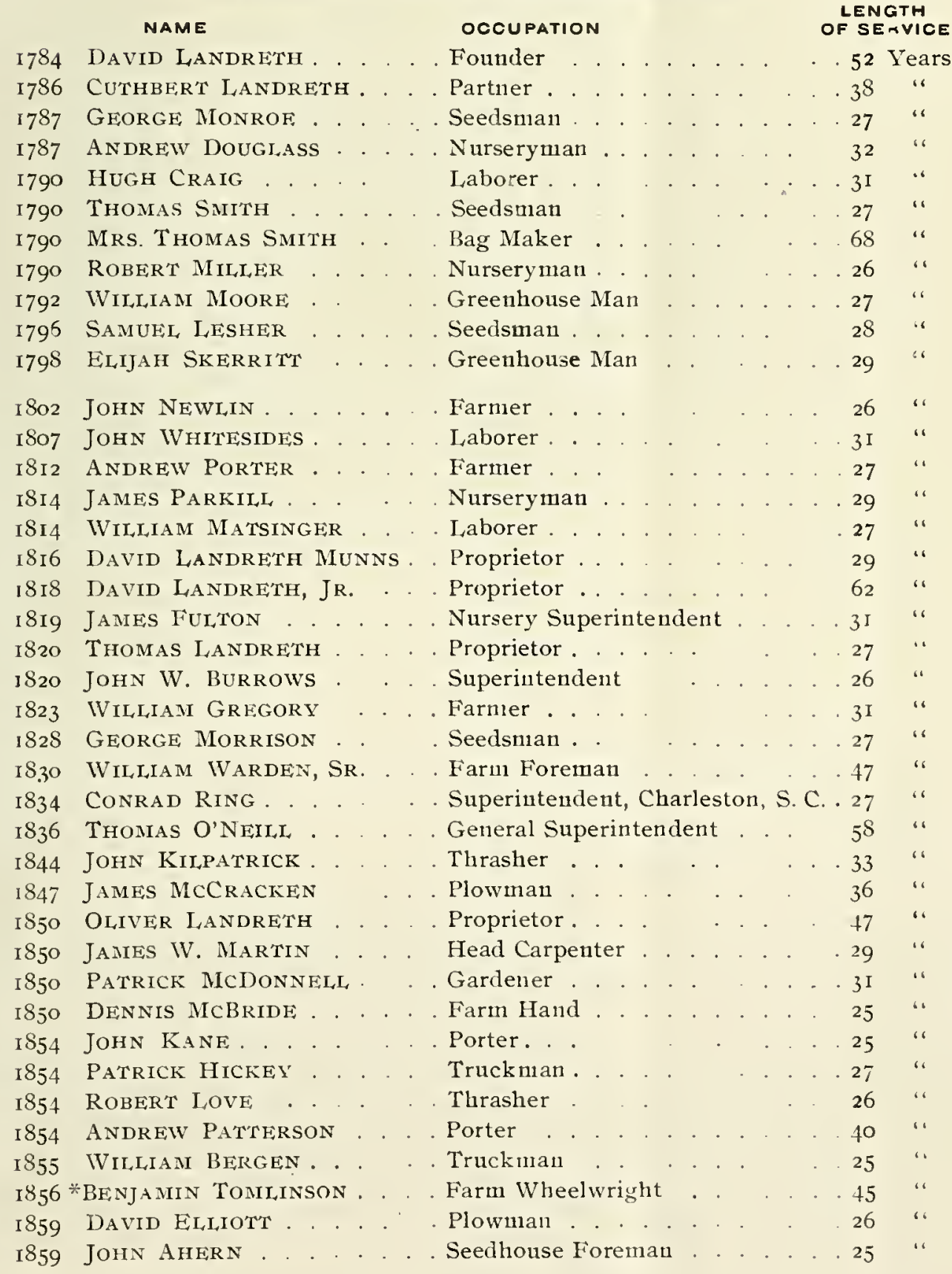





\section{NAME}

IS60 *RoBERT P. CARPENTER

I86I TIMothy Fahy . . . .

IS6I JOSEPH PATTERSON .

I862 * BURNET LANDRETH . .

I 862 * J A COB T. WOODING'TON

I 863 *JAMES MCLAUGHLIN .

I863 MATTHFW BaLDWIN .

$1865 *$ CHARLES JOHNSON

I865 *WILLIAII C. HibBS

I865 JOHN L. HIBBS . .

I 865 ALBER'T MARTIN

I $65{ }^{*}$ HeNRY C. HibBs .

I866 DANIEL, JOHNSON

1866 WILLIAM WARDEN, JR.

IS66 PATRICK SUTTON.

I $867{ }^{*}$ LEOPOLD I,ANDRETH

i 667 * Henky M. Phit, Ler .

IS67 *ANDREW MCCUEN

I 867 JOHN WARDEN

IS69*Charles G. A. Thamm

I869 WILLIAM RITCHIE.

IS69*HENRY SuITH . .

1870 *A A LFRED C. SMITH

$1870 *$ Lincolan HibBS

I $870 *$ GEORGE GRIFFIN

1870 JAMES J. O'NEIL .

I87 I *JOHN JACKSON .

I87 I MAT JACKSON

IS7 I ROBERT THONAS

¿S72 MaLACHI THOMAS

$\mathrm{IS}_{72}$ *KATE TyNAN .

IS73 LEWIS JACKSON .

I 873 * WILLIAM FARINA

I $873^{*}$ GEORGE DAvis

I 873 *IVILLIAM WinsLoW

I 873 *JACK IVADNIE .

IS 75 *NED BALL. .

1876 * BENJ. GROFF . .

IS76 *ThOMas H. HILL,

IS76*IVILLIAM COLEMAN

IS76 * JAMES COLEMAN .

IS76 *FANK KNIGHT .

IS 76 *ROBERT COLEMAN

IS 76 *GEORGE TURNER

\section{DOCUPATION}

Correspondence Department

Warehouse Foreman

Packer

Proprietor

Salesman . .

Greenhouse Man

Porter

Correspondence Department

Foremen

Foreman

Commercial Traveler

Farm Engineer. .

Farnier

Seedhouse Foreman

Laborer.

Proprietor

Head Bookkeeper.

Seedhouse Foreman

Seedhouse Foreman

Correspondence Departuent

Packer

Correspondence Department

Jersey Foreman, Jersey Farm .

Carpenter

Virginia Laborer

Commercial Traveler

Virginia Laborer .

Virginia Laborer

Virginia Laborer

Virginia Overseer

Girls' Department

Virginia Laborer

Head Thrasher

Virginia Engineer

Packer

Virginia Laborer

Virginia Laborer

Plowmau

Commercial Traveler

Plowman

Warehouse Foreman .

Commercial Traveler

Seedhouse Foreman

Virginia Overseer .
OF

jE

4 I Years

26

. 27

39

39

39

. 28

36

.36

33

25

36

25

27

25

.33

.34

34

. 26

.32

32

32

31

$3 \mathrm{I}$

25

28

30

25

26

26

29

28

$2 \mathrm{~S}$

$2 \mathrm{~S}$

$2 S$

. 28

. 26

.25

. 25

. 25

. 25

25

. 25

25

The records of the Firm show the names of over two hundred old employes of less than twenty-five years' service and over fifteen. These men, though not named as those of twenty-five or more years of service, were equally faithful.

The Landreth Firm is one of the thirtr-two coumercial Establishments of the Uuited States formiug the Association of Centenary Firms-firms for over one hundred years continuously administered by the direct descendants of the founder.

The Association was conceived and to a large extent organized by Mr. Burnet Landreth, one of the members of this firm, who is also the Association President. 


\section{NAME}

IL , NOBER'T P. CARPENTER

I86I TImothy FAHY

I 86 I JOSEPH PATTERSON

I 862 *BURNET LANDRETH

I 862 * J A COB T. WOODINGTON

I 863 "JAMES MCLA UGHLIN

I 863 MATTHEW BALDWIN

I 865 *CHARLES JOHNSON

I $865 *$ WII,LIAII C. HIBBS

I 865 JoH N L. HiBBs.

I865 ALBERT MARTIN

I 865 *HENRY C. HIBBS .

I866 DANIEI, JOHNSON

I 866 WILLIAM WARDEN, JR.

I 866 PATRICK SUTTON .

1867 *LEOPOLD LANDR ETH

I 867 *HENRY M. PHILLER .

I 867 *ANDREW MCCUEN

I 867 JOHN WVARDEN

I869* Charles G. A. Thamm

I869 WILLIAM RITCHIE.

I 869 *HENRY SMITH . . .

1870 *A LFRED C. SMITH

1870 *LINCOLN Hibes.

I870 *GEORGE GHIFFIN

I87O JAMES J. O'NEIL .

I87 I *John Jackson .

I87I MATJACKSON.

I87I ROBERT THOMAS

1872 Malachi Thomas.

I 872 * Kate TYNaN

I873 LEWIS JACKSON

I873 *WILLIAM FARINA

I 873 *GEORGE Davis

I 873 *WILLIAM WinstoW

1873 *JACK WADNIE:

I875 * NED BALI, . .

I 876 *BENJ. GROFF

I876 *THOMAS H. HILI

i 876 *Wilitam Coleman

I876 *JAMES COLEMAN .

I 876 *FRANK KNIGHT .

I 876 * Rober't CoLEMAN .

I $876 *$ GeOrge TURNER
OCCUPATION

Correspondence Department

Warehouse Foreman

4 I Years

Packer

Proprietor

Salesman .

Greenhouse Man

Porter

Correspondence Department

Foremen

Foreman

Commercial Traveler

Farm Engineer

Farmer

Seedhouse Foreman

Laborer .

Proprietor .

Head Bookkeeper.

Seedhouse Foreman

Seedhouse Foreman

Correspondence Department

Packer. .

Correspondence Department .

Jersey Foreman, Jersey Farm .

Carpenter.

Virginia Laborer

Commercial Traveler

Virginia Laborer . . .

Virginia Laborer .

Virginia Laborer

Virginia Orerseer

Girls' Department

Virginia Laborer

Head Thrasher

Virginia Engineer.

Packer

Virginia Laborer

Virginia Laborer

Plowman

Commercial Traveler

Plowman .

Warehouse Foreman

Commercial Traveler

Seedhouse Foreman.

Virginia Overseer .
26

27

39

39

39

28

36

36

33

25

36

25

27

25

.33

.34

34

26

32

32

32

$3 \mathrm{I}$

3 I

25

28

30

25

26

26

29

28

$2 S$

- 28

28

28

26

25

25

25

25

25

25

25

The records of the Firm show the nanies of orer two hundred old employes of less than twenty-five years' service and over fifteen. These men, though not named as those of twenty-five or more years of service, were equally faithful.

The Landreth Firm is one of the thirtv-two commercial Establishments of the United States forming tlie Association of Centenary Firms-firms for over one hundred years continuously administered by the direct descendants of the founder.

The Association was conceived and to a large, extent organized by Mr. Burnet Landreth, one of the members of this firm, who is also the Association President. 

EIGHTY-FIVE WORKERS OF OVER TWENTY-FIVE YEARS OF SERVICE.

\section{$* * 2$}

Those marked* are yet on the Rolls, January, 1901.

\section{NAME}

$17 S_{4}$ DAVID LANDRETH .

1786 CUTHBERT LANDRETH .

${ }_{17} 78$

I 787

1790

I 790

1790

I 790

I 792

I 795

I $79 \mathrm{~S}$

ISO2 JOHN NEWLIN .

ISO7 JOHN WHITESIDES .

ISI2 ANDREW PORTER

ISI 4 JAMES PARKILL.

ISI4 WILLIAM MATSINGER

I816 DAVID LANDRETH MIUNNS .

ISIS DAVID LANDRETH, JR.

I 8 I9 JAMES FultoN .

ISZO THOMAS LANDRETH

IS2O JOHN W. BURROWS

I823 WILLLAM GREGORY

$182 \mathrm{~S}$ GEORGE MIORRISON

IS 30 WILLIAM WARDEN, SR.

IS34 ConRad Ring.

I 836 ThOMAS O'NeILL.

IS44 JOHN KILPATRICK .

IS47 JAMES MICCRACKEN

IS5O OLIVER LANDRETH

IS5O JAMES IV. MaRTIN

IS5O PATRICK MCDONNELL.

iSjo DENNIS MCBRIDE.

IS54 JOHN KANE.

IS54 PATRICK HICKEY

IS54 ROBERT LOVE

I854 ANDREW PATTERSON

IS55 WILIIAM BERGEN . .

I856 * BENJAMIN TOMIINSON .

1859 DAVID ELLIOTT

I859 JOHN AHERN .

\section{OCCUPATION}

Founder

Partner.

Seedsman

Nurseryman .

Laborer

Seedsman

Bag Maker

Nurseryman

Greenhouse Man

Seedsman

Greenhouse Man

Farmer

Laborer

Farmer

Nurseryman

Laborer .

Proprietor . .

Proprietor .

Nursery Superinteudent

Proprietor .

Superintendent

Farmer

Seedsman .

Farm Foreman

Superintendent, Charleston, S. C. . 27

General Superintendent . . $5 \mathrm{~S}$

Thrasher . . . . . . 33

Plowman . . . . . 36

Proprietor . . . . . . 47

Head Carpenter . . . . . . 29

Gardener . . . . . . . . 3I

Farm Hand . . . . . 25

Porter. . . . . . 25

Truckman..... . . . . 27

Thrasher . . . . 26

Porter . . . . . . . . 40

Truckman . . . . 25

Farm Wheelwright . . . . 45

Plowman . . . . . . 26

Seedhouse Foremau . . . . . 25
ENGTH

SERVICE

52 Years

$3 \mathrm{~S}$ "

7 "

2 "

3 I “

27 "

68 ،

6 ،

7 "

8 is

9 "6

6 “

I “

27 .

29 “

7 "

29 "

62 “"

I “

27

26.

I “

7 .

7 “

7 “

“

3 “

c.

$$
\text { " }
$$

$$
\text { ، }
$$$$
\text { ، }
$$

$$
\text { , }
$$

$$
\text { " }
$$

$$
\text { is }
$$

."

"

".

6 .

25





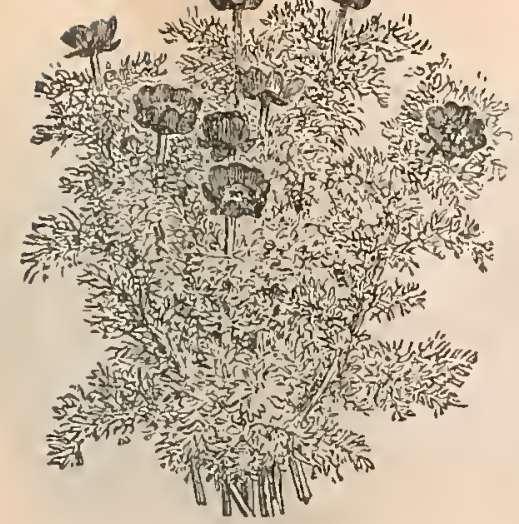

ADONIS AUTUMNALIS.

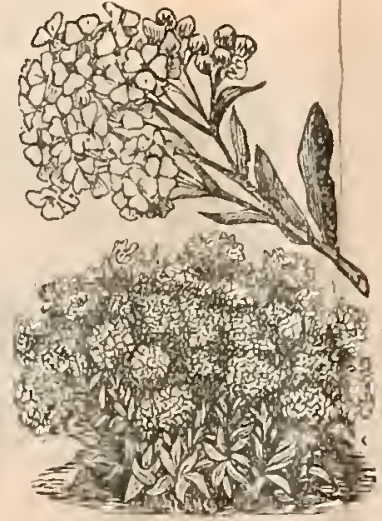

ALYSSUM (SWEET) MARITIMUM.

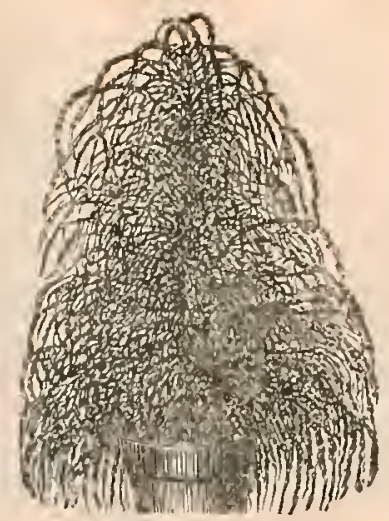

AMARANTHUS SALICIFOLIUS.

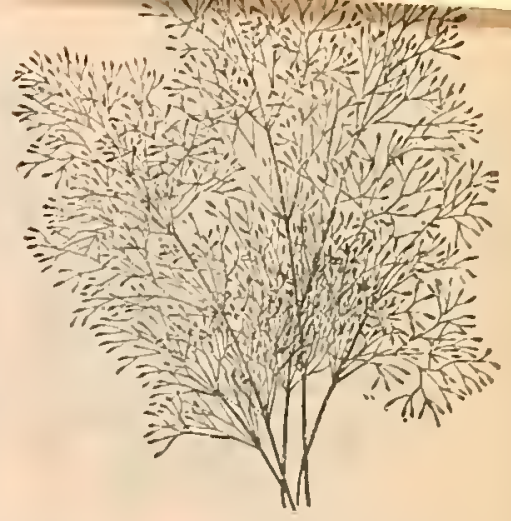

Price fier Packet, Cts

Anemone sylvestris. - White. 6

inches..................

hardy perennial bulbous-rooted plants, among the most beautiful of forists' flowers.

Antirrhinuin majus.-Crimson and white. $I \frac{1}{2}$ feet .......

Antirrhinum nana (Tom Thumb).Mixed colors. 6 inches.

Antirrhinum picturatum. - Tinted varieties mixed. I foot

The Antirrhinums, or Snap Dragons, are hardy perennials, blooming first season if sown early. Among the most showy and brilliant border plants, succeed in any good garden soil.

Aquilegia chrysantha (Columbine).Golden. 3 feet.

Aquilegia hybrida.-Nixed. 2 feet.

Aquilegia skinneri. - Scarlet and yellow. I $1 / 2$ feet.

The Aquilegia, or Columbine, is amongst the most beautiful and curiously formed of hardy perennial flowers. Blooms in the early Spring and Sumner.

Aristolochia.-See Vines and Climbers.

Arundo.-See Ornamental Grasses.

Asperula azurea setosa.-Blue. Hardy annual, bearing a profusion of sweet-scented blue flowers. I foot.

Aster (Queen Margaret).- Bouquet dwarf. Crimson, violet and white. I foot ..........

Aster chrysanthemum.-Dwarf.

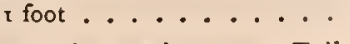

Aster shrysanthemum.-Tall.

$1 \mathrm{t} / 2$ feet ......... no

Aster corcordea. - Double, bright colors. White centre. I I $/ 2$ feet . . 10

Aster Diamond. - Large flowered, various colors. $1 \mathrm{I} / 2 \mathrm{feel} . . . . .10$

5 Aster globe-flowered.-Various colored. I $1 / 2$ feet . . . . . . . Io 5 Aster meteor.-Bright crimson.

I foot ............ Io Aster mignon.-Pure white. I foot. 10
Price per Packet, Cts.

Aster pæony-fowered. - Mixed colors. I foot . . . - . - . red. I foot. .

Aster Victoria.-Sulphur yellow. I foot

Aster Washington. - Light purple $1 / 2$ feet

Aster German mixed. $-I^{1 / 2}$ feet

The Asters are surpassingly beautiful annual plants. All shades and colors are represented in the above assortment. The seed should be sown under glass or in a seed bed, and transplanted into deeply-dug, highly-enriched soil, mulching and irrigating with manure. Water during a drought is absolutely essential to a healthy vigorous growth.

Asters. - Perennial. Star fowers, various colors. I foot.

Auricula. - See Primula auricula.

Azalea. - Perennial. Mixed colors. 3 to 4 feet

The varieties of this handsome genus of plants are numerous. Coland pink, with intermediate shades. Requires moist, peaty soil or black sandy loam and shady situation.

Bachelor's Button.-See Everlasting Flowers (Gomphrena).

Balsam (Impatiens balsamina, Atrosanguinea, plenessima). - Blood red. 2 feet. .

Carnation.-Striped mixed. 2 feet. Camelia. - White-blotched mixed. 2 feet.......... Rose.-Mixed colors. I foot.. Solferino.-Striped and spotted. 2 feet.

The King.-Bright scarlet. 2 feet. Double.-White, pure, for bouquets. 2 feet.

Double.-Mixed. 2 feet .... The Balsam, Lady's Slipper or Touch-me-not-the latter name de. rived from the fact that the seed pods, when fully ripe, burst open with the least touch-is a family of beautiful annuals. Rich soil and deep culture is requisite to produce large and showy flowers. ors are white, yellow, orange, scarlet
Price per Packet, Ct.

Balsam Apple and Pear.-See Vines and Climbers.

Balloon Vine. - See Cardiospermum. Vines and Climbers.

Baptisia australis. - Blue. Harcy perennial, handsome border plant. producing blue flowers in termiral spiked racemes in June. 2 feet . .

Bartonia aurea. - Golden yellox. Hardy annual, easy culture. 18 .nches.

Beans, Scarlet Runner. - See Vines and Climbers.

Beans, Hyacinth. - See Tines ans: Climbers.

Begonia semperfiorens. - Tuberousrooted. Mixed colors. I $1 / 2$ feet. . =

Begonia hybrida. - Tuberous-rooted. Iixed colors, 2 feet

Begonia rex hybrida.-Fibrous rooted. Mixed colors, handscme foliage. 6 inches

Beautiful hothouse or greenhouse plants, or during Summer in the garden. Require rich soil, and plenty of moisture. Propagated by seeds, cuttings, or division of tubers.

Bellis Perennis (Daisy). - Mixed coors. 6 inches

Bellis Longfellow (Double rose Daisy). -6 inches

Bellis (Double white Daisy). -6 inches 30 The Daisy is a perennial plant of poetical celebrity. Native of England and Scotland. Quite hardy in most situations, easy culture. $c$. quires shade. Flowers from Apri? to-June. Start seed in hotbed.

Bidens atrosanguinea (Dablia $\mathrm{Zim}$ pani).-Crimson. Hardy annual, showy flowers resembling sing !e Dahlia. 2 feet .

Bocconia Japonica. - Magnificent

Brach y come iberidifolia (Swan Daisy), - Blue and white. Beautifu! hardy annual, in flower from July to September. I foot.

Briza.-See Ornamental Grasses.

Bromus.-See Ornamental Grasses. foliage plants. Perennial. 4 feet . 


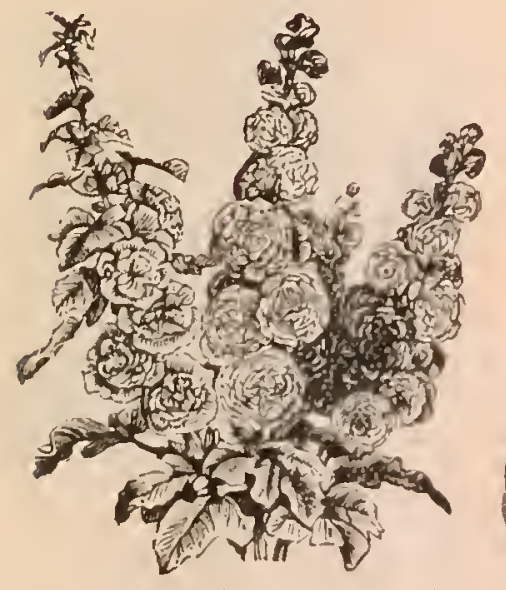

HOLLYHOCK (A I.THEA SINENSIS).

\section{Price Per Facket, Cl}

Browallia elata (Amechyst). - Mixed colors. A tender annual from Peru. Bears an abundance of blue and white flowers from July to Septem. ber. Sow in hotbed and transplant in June. 15 inclies.

Bryonopsis. - See Gourds.

Gacalia coccinea (Tassel Flower).Scarlet. 18 inches.

Cacalia lutea (Tassel Flower). - Yel. low. Is inches

The Cacalia, or Flora's P'aint Brush, sa very pretty aumual, in flower from July to October.

Calandrinia. - Half hardy annual.

Mixed colors. I foot

Calce olaria hybrida. - Ifixed color: 25 inches....

Calceolaria tigrina. - Spotted. inches.

Beautiful greenhouse plants, with pocket-shaped flowers motted and sposted.

Cale mpelis. - See lines and Climbers

Calendula maritima. - Double yellow. I foot.

Calendula officinalis meteor, Double striped orange. I for

Calendula pongei. - Double white. I foot

Calendula (Prince of Cirange) - - Dark golden double. I foot .

J Handsome hardy annuals,

monly called Cape or Pot M.urigold. Bloum continuously all the serson. Easy culture.

Calliopsis atrosanguinea. $-\mathrm{B}$

red. I foot.

Calliopsis drummondii.-Golden,

with crimson centre, I foot

Calliopsis marmorata.-Brown, vel-

low and crimson. 1 tiz feet

Calliopsis, Miixed, all colors. = feet.

Calliopsis hybrida. - New double

mixed. Ifoot.

Calliopsis or Coreopsis are laarly annual plants of easy" culture, very beautiful, especially when grown in

Campanula medium Lanterbury. Bellt.-.llixed colers, dwak'e and

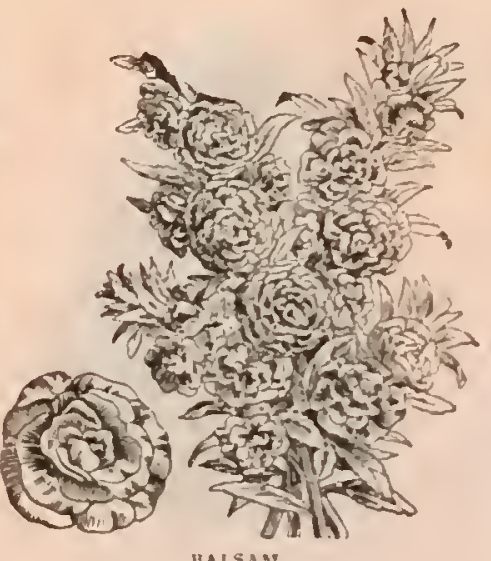

BALSAS.

frice per finctie?,

Campanula pyramidalis (Pyramidal Bell Flower). -2 feet.

Campanula calicanthema (Cup and Saucer).-Ilixed colors. a fect. .

Campanula rotundiflora (IIair Be!l). -White and blue. = feer.

Campanula speculum (Venus' Loching Glass).-Blue and white, 2 feer.

The Campanulus are a lange genus

cf showy plants, mostly perennials.

The Cam panula medium (Canterbury Bell) claims a situation in all gardens.

Eas y of culture and certain to flower. all succeed well in good soil.

Candytuft. - Sce Iberis.

Canna aurantiaca. - Golden. a feet.

Canna coccinea. - Scarlet. 3 feet.

Canna Marechal Vaillant.-Orange 5 feet.

Canna d warf French. - Mised colon.

Canna indica-Mived sorts. \& feet

"The Cinnas are montly" tropical.

half hardy, pereusial plants, with

elegan foliage and showy dowers: produce a striking eflect grouped in

beds or sins:ly on the lawn. Sulk

the seed in warm water about twelve hours, sow in hotbed, plint ou: when ground is warm ; give plenty of moisture and rich soil. lake up the roots before frost, and heep in moderascly warm cellar.

Carnation.-See Dianthus.

Cardiospermum. - See $\mathrm{V}$ ines and Climbers.

Castor Beans. - See Ricinns.

Catch fly. - Sec Silene.

Celosid cristata. coccinea nana (Dwarf Cockicomb).-Scarlet. = iect

Celosia cristata plumosa (Feathered

Celosia cristata aurantiaca (Orange

Cucksiomb -3 feet .

Celosia cristata (President Thiers).bight crintson dwarf. a fect.

Celosia eristata.-Mixed. a teet

The Cockisombs are tender annuals, 1equire rich soil, will attain rich color and largestac by repeated shiftings; cut off side flowers and
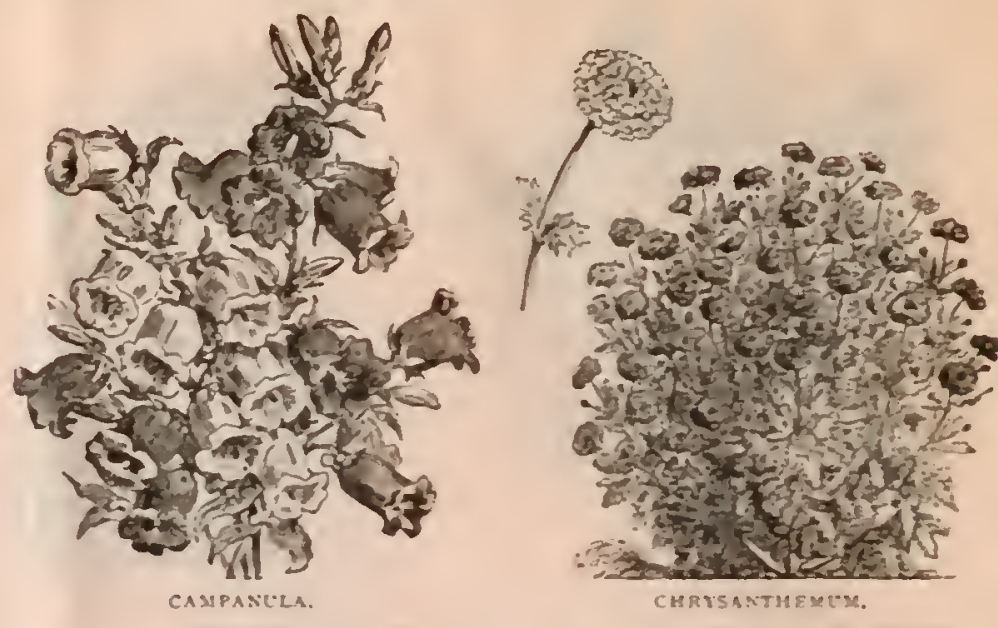

Fraseperfusei, cas

leave one head only to a plast. If

cut before they tace the head may be preserved during the W' inter.

Centaurea Americana (Star Thistic -Lilac. 2 fee?

Centaurea candidissima.-\$ilver leaved. I fuce.

Centaurea clementei. - Silver-leaved. 5 inches.

Centaurea gymnocarpa. - Silverleaved. 15 inches.

Centaurea cyanus f Blue Botrle Ifixed colors. $1 !$ fec?

Centaurea moschata (sweet Suluan. -Purple. I foot.

The Centaureas are hardy annuals, of easy cu'ilite. The whise-leaves var eties, Candidissima, Clemertei and Gymnocarpa, are valuabie fur borden and ribbon teding. The ther varieties make beautif: add.ons to the fiower bed.

Centranthus. - Red and wh se. Handsome border anurals. I foot.

Cheiranthus cheri (Wall Flowe), Sirgle mixed. $2 \mathrm{fed}$.

Cheiranthus cheri.-Duast, tru un, donble. I foot

Cheiranthus cheri. - Dovulie yellos. in feet.

The Wall Flower is a great favaise. It is a half-hardy bienn a?, pro. ducing heautiul, fagsant thers. Requires protectiond arirg the WI: ter.

Chrysanthemum coron rium.Mrixeci culars. I foor....... Chrysanthemum burridgeanum. crimson and white. $x$ fors

Chrysanthemum (Eulipse) - Gotús ellow. I fore.

Chrysanthemum sulphurium.11. mible yellow: $1^{2}$ inest.

These varictie of chrysantenum are hurdy anmuls, lexy fretty, esiecially when stown an mus.s. E.sy" culture, stand the heat, re quire rich scil.

Cineraria hybrida. - Mixed coluss feet.

Cineraria hybrida. - Exira se'ice awsurf. a fiver
Prise jer facki, Cos.

Cinerara marifima eandidissima. - Elver foliage. 2 feet ...... Cineraria maritima acanthifolia.slver foliage. a feet ........

The A.wers of a e Cincraras are afier the ral.: of the berbuceous Aste: : fetas of masy colors, eye of difierent shaces. Hardy greenhouse annua's: very aisactire duri ह II inter and spring. The Nafir ma varvenes are 1 alf - hardy perennali, desurable fur borders and a iblon beddiag.

Clarkia elegans. - Double arixed colors. I $2 \mathrm{fes}$.

Clarkia pulchella. - Mixed colors. 1 1) 2 feet. .

Very fretty anasals May be sow a in the Fall and prosecaed during the IInter, or soun carl! in the Sprizes. Clematis.-see liacs aad Climbers. Cleome grandifiara or Arborea.Rove-colored sardes. The Cleare requires rich soil. It is a half harsy anausl, b ocms cosutinuousy through the Summer and is ege te showy. 3 feet.

Clianthus dampierii. -Scarled. The Clias:hus, or G!org Iex, is $x$ :ender pereanial, beasng scarted gei-s apod fiowers: sueceecis bes in green house. I fee:

C!irtonia, var. - See Tralirg Pisass. Cobza scandens. - Sie lames ala Cumbers.

Ceccines indics - See Geands.

Coir lachryma. - Ece Crmameacel Grase:

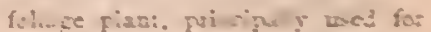

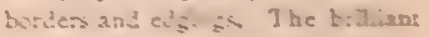
shades of tronar, yeiow, stces, cr.msio and red male it very siiractive. Rainod formansers of rai-

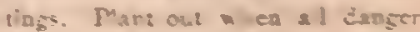

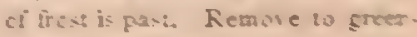
house in Fa't. 1 tixt.

Collinsia, var, - Mixat cokex Hari:

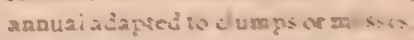

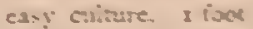

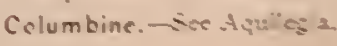

Coleus. var-lis a tender jereanal 


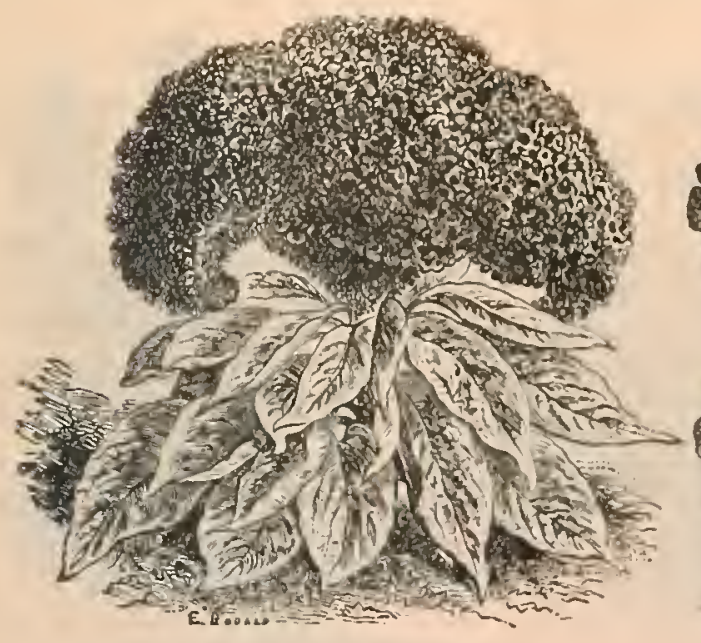

CELOSIA CRISTATA.

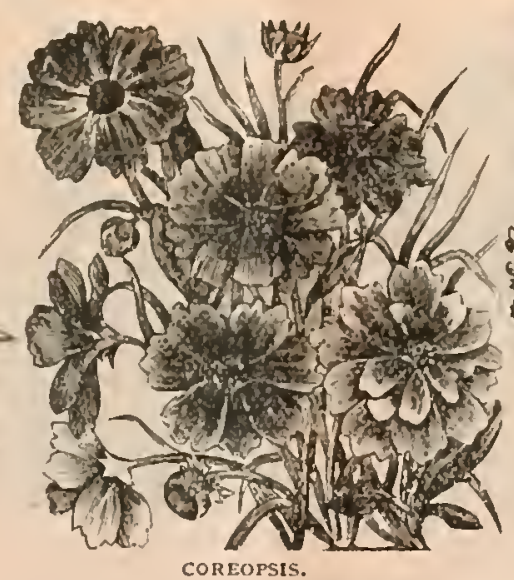

COREOPSIS.

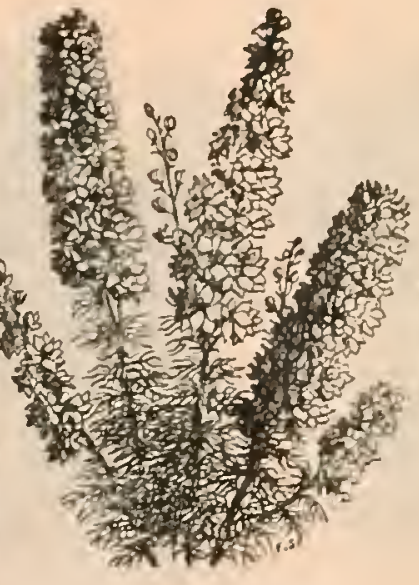

DELPHINIUM (LARKSPUR).

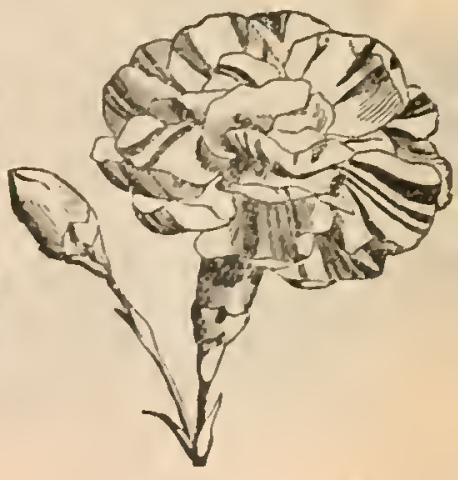

DIANTHUS CARYOPHYLLES
Price per Packet, Cts

Commelina var. - Mixed colors. The Commelina is a perennial, tuberous. rooted Mexicau plant. Colurs are blue, white and variegated: easily raised from seed. 2 feet .....

Convolvulus minor. - See Trailing Plants.

Convolvulus major. - See Vines and Climbers.

Convolvulus mauritanicus. - See Trailing Plants.

Cowslip.-See Primula.

Coreopsis. - See Calliopsis.

Cucumis.--See Gourds.

Cucurbita. - See Gourds.

Cuphea platycentra tricolor.Cuphea, or Cigar Plant, is a tender - perennial; grows freely, can be propagated by cuttings. $I \frac{1}{2}$ feet .

Cyclamen persicum. - White and rose. Tender perennial, bulbous. rooted, beautiful fragrant flowers: protect during Winter, have soil well drained. 6 inches .

Cypress Vine. - See Vines and Climbers.

Dahlia.-Various colors, double. 5 feet...

Dahlia.-Various colors, single. 5 feet ......

Dahlia. - Various colors, dwarf double. 3 feet...

The Dahlia is a well-known favorite. The colors and shades of colors are many; is a half-hardy perennial, tuberous-rooted, deserving a place in every garden. Blooms till frost. Keep the roots during IVinter in a dry cellar, free from frost.

Daisy. - See Bellis Perennis.

Datura fastuosa (Trumpet Flower). -Various colors. 3 feet ....

Delphinium (Tall Rocket Larkspur). -3 feet. . .

Delphinium(Dwarf Rocket Larkspur, var.). -1 foot.........

Delphinium consolida (Branching Larkspur, var.). $\rightarrow 2$ feet. . . . . Delphinium elatum (Bee Larkspur, var.). -3 feet
Price per Packet, Cts.

Delphinium formosum. - Blue and white. 2 fcet........ Delphinium grandifora calestinum.-Blue. 2 feet ......

Delphinium ranunculus flowered, var. $\rightarrow$ foot .

The Larkspurs are sho $v y$ annuals and pcrennials; beautiful border flowers. Foliage much divided, flowers in terminal spikes, blue, purple, white and red. The blue flowers arc very brilliant. The Dwarf and Tall Rocket, and Consolida, are annuals, the others are perennials. The annuals will succeed better if the seed is sown in the Fall, and protected during Winter. All grow freely in good soil.

Dianthus Caryophyllus (Carnation Pink, var.) -2 feet . . . . . . .

Dianthus Caryophyllus (Carnation Pink).-Double striped. Extra. 2 feet. .

Dianthus Caryophyllus (Carnation Pink).-Dwarf red grenadine. $1 / 2$ feet. .

Dianthus chinensis (China Pink).Double variety. I foot .

Dianthus heddewigii (Japan Pin)k. -Double variety. I foot.

Dianthus diadematus. - Dwarf, double mixed. I foot...

Dianthus imperialis (Imperial). Double mixed. I foot.

Dianthus laciniatus. - Fringed, double mixed. 2 feet....

Di a n thus plumarius (Pheasant's Eye).-Single mixed. 2 feet ...

Dianthus barbatus (Sweet William). -Double mixed. I foot . .

Dianthus barbatus (Sweet William). -Single mixed. r foot ..

Pinks in their perfection are surpassed by few garden fiowers. The Chinensis, or Indian Pinks, and Heddewigii, are annuals or biennials, the other variesies are perennials. Pinks and Sweet Williams are old favorites, nearly all are fragrant. Rich soil will make bright flowers.
Price per Packet, C: The Dictamnus, or Gas Plant, is a hardy perennial, flowering in June and July. The seeds should be soaked in hot water 12 hours before planting.

Digitalis purpurea (Purple Foxglove). -4 feet . . . . . 4 feet.

Digitalis monstrosa var. (Tall Foxglove). -4 feet

Digitalis maculata (Spotted Foxglove). -3 feet . . . . . . . The Digitalis are hardy perennials of easy culture, living for several years without care, and yielding tall spikes of showy ringent flowers.

Dolichos.--See Vines and Climbers.

Erysimum Peroffskianum.-Orange Erysimum, or Hedge Mustard, is a hardy annual bearing racemes or spikes of deep orange blossoms from June to September. I foot. Erianthus.--See Omamental Grasses. Eschscholtzia Californica (California Poppy).-Yellow. I foot

Eschscholtzia alba.-IVinite. I foot. Eschscholtzia crocea.-Orange.

I foot

Eschscholtzia crocea striata.Striped. I foot.

Eschscholtzia.-Mixed, various colors. I foot..

Eschscholtzia crocea, fi.pl.-Double flowered. I foot.

The Eschscholtzia is one of the most beautiful and showy of garden flowers. When grown in masses, scarcely any plant produces a greater degree of splendor. Easily raised from seed. Sown in Autumn the growth is of increased vigor.

Eucharidium breweri.-Purple and white. Hardy annual, showy when grown in masses. I foot

Eulalia.-See Ornamental Grasses.

Fenzlia dianthiflora.-Rose and white. Hardy annual, dwarf habit, very pretty for borders or ribbon bedding. Flowers all Summer; water freely. 6 inches. .
Price per Packet, Cls.

Feverfew. - See Matricaria.

Flax.-See Linum.

Four o ${ }^{\circ}$ Clock. - See Mirabilis I alapa. Foxglove.-Sce Digitalis.

Forget-me-not.-See Myosotis.

Fuchsia (Lady's Eardrop).- Mixed colors. The Fucbsia is a well-known and favorite flower, of easy culture. Tender perennial, requiring shade and moisture. 2 feet .

Gaillardia alba merginata.-Crimson and white. $1 \frac{1}{2}$ feet.......

Gaillardia picta lorenziana.-Bright culors. 2 feet

Gaillardia picta.-Mixed. 2 feet. . The Gaillardias are half-hardy, free-fowering annuals. The lowers are a very showy combination of orange, crimson and purple, blended and streaked in many ways.

Gaura lindheimeri.-Red and white. Is a half-hardy annual. It fiowers on numerous branches, continuing in bloom till frost; very desirable for houguets. 3 feet .

Gentiana a c a lis.-Blue. Harcy perennial, easy culture. 6 inches. Geranium pelargonium.-

Scarlet, Choice.

Tom Thumb.

Choice Mixed

Half-hardy perennials -2 feet. Sow in seed bed in Spring, keep moist and plant out in rich sandy loam. Cuttings may be easily started in pots if kept moist and shady. Take up in the Fall, pot and keep in a moderately cool cellar during Winter.

Gillia capitata.-Blue, I foot .. Gillia nivalis alba.-White. I foot . Gillia tricolor. -Three colors... Gillia.-Mixed ...

Neat, unpretending annuals, long in bloom, easy culture, fine for rock'vork.

Gladiolus hybrida.-Half-bardy perennials; various colors and shaces of col rs. 3 feet....... 


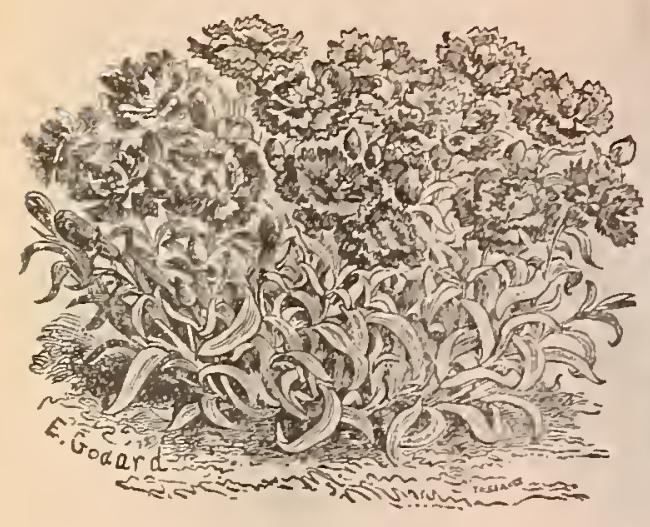

DIANTHUS CHINENSI
(CHINA PINK)

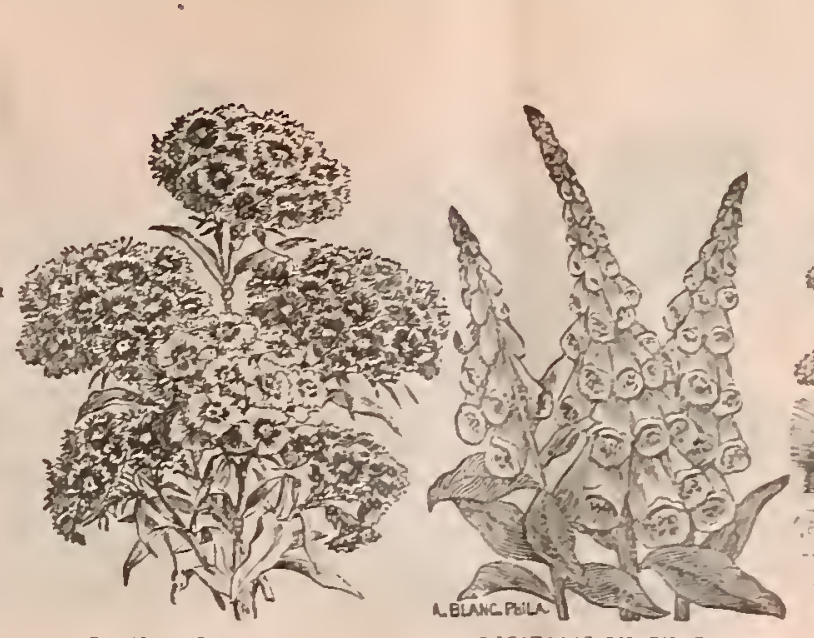

DIANTHUS EAREATUS

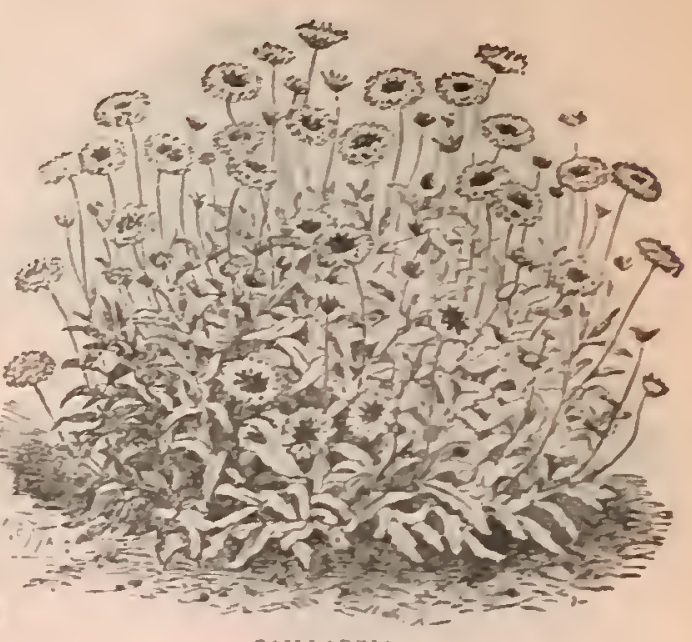

GAIRLAPMIA.
Price per Packet, Cls

Gloxinia hybrida.-Various colors. The Gloxinias are tender perennials, suited to the conservatory or greenhouse. Their large bell-shaped flowers are of great beauty, shaded, spotted and marked in the most attractive sty.le. I foot...

Godetia rubieunda splendens. Purple and red. Beautiful hardy annuals, of easy culture in good soil. Flower freely all the seasons, 2 feet.

Golden Feather.-See Pyrethrum.

Gomphrena.-See Everlastings.

Gynerium.-SeeOrnamental Grasses.

Gypsophila elegans. - Purple and white. Hardy annuals, fine for bouquets; easy culture. I foot .

Hedysarium. - See Vines and Climbers.

Helianthus argophyllus (Texas Silver Leaf).-Siriped. 6 feet.

Helianthus Californicus. - Golden. 6 feet. .

Helianthus giganteus (Russian).Golden. 8 feet

Helianthus nanus.-Dwarf double, orange. 3 feet.

Helianthus globosus. - Globe flow ered, yellow. 3 feet .

The Sunflower is a well-known old-fashioned favorite, of Iate years wonderfully improved. The above varieties are all annuals. The size and brilliancy of their flowers make them worthy of a place in every garden.

Heliehrysum. - See Everlastings.

Heliophila araboides. - Blue. Halfhardy annuals, easy culture; sow in open border in early Spring. to inches.

Helipterum.-See Everlastings.

Heliotropium.-Shades of blue. The Heliotrope is a swee scented, ten. der perennial. Grows freely in the garden or greenhouse. Fine for bouquets. 2 feet.

Hesperis matronalis. - Purple and white. Hesperis, Garden Rocket, or Darne's Violet, is a biennial, easily raised from seed, and may be perpetuated by division of roots or by cuttings. 2 feet.......

\section{Hibiseus afrieanus - Yellow and}

brown. 2 feet.......

Hibiseus moseheutos. - White and rose. 3 feet

Hibiscus is a very showy flower. Africanus is annual; the Moscheutos or Rose Mallow is perennial.

Hollyhock.-See Althea.

Hyaeinthus candieans. - Wh ite. Cape $\mathrm{Hy}$ acinth is a very landsome, fragrant perennial, suitable for the centre of a bed, or singly in lawn. 4 feet. .

Iberis amara (White Candytuft).I foot...

Iberis eoronaria (Rocket Candytuft). -White. I foot

Iberis earminea (Carmine Candytuft). - I foot

Iberis odorat3.- White. I foot. Iberis purpurea.-Purple. I foot. Iberis, var.-Mixed colors. I foot . The Candytuft, a well-known favorite, is a hardy annual, very pretty in beds or masses. Seed may be sown in the Fall for early flowering. Ice Plant. -See Mesembronthemum. Ipomea. -See Vines and Climbers.

Ipomopsis aurantiaea. - Golden. 2 feet

Ipomopsis elegans (Scarlet Cantua) -3 feet.

Ipomopsis are hardy biennials. natives of the South; very beautiful,

Lantana hybrida. - Tarious shades. Tender perennials; easily raised from seed or increased by cuttings. Fine bedding plants. The flowers are of brilliant changeable colors. 2 feet.

Lathyrus odoratus. - See lines and Climbers.

Lathyrus latifolius.-See lines and Climber.

Lavatera.-Red and white. Hardy annual, easy culture, handsome ap pearanee. In bloom from July to October. 2 feet

Leptosiphon hybrida. - Different colors. Hardy annuals; beautiful tuhe-shaped fowers, I foot....

(FOX

Priceper racket, Cis.

Limnanthus douglasii. - leliow and white. Hardy annual, bearing nimerous fragrant flowers; deep yellow, with white petals. I foot.

Linaria.-See Trailing Plants.

Linum grandiflorum rubrum (Scar. let Flax).-Hdf-hardy annua!, free flowering, and quite handsome. I foot

Lohelia cardinalis (Cardinal Flower). -Scarlet perennial. 3 fee:

Lobelia erinus, and others. - See Trailing Plants.

Lophospermum. - See l'ines and Climbers.

Luffa.-See Gourds.

Lupinus, var.-Mixed colors, annuals. 3 feet. .

Lupinus, var. - Mixed colors, perennials. 3 feet

The 1.upinus are very pretty,

showy plants, with pea-shaped blosThe annuals and pererniai: grow readily from seed. The later inay be perpetuated by dividing the

Lyehnis alba. - Mbite. 2 feet

Lyehnis ehalcedoniea. $-\$ c a r l e t$.

2 feet. .

Lyehnis haageana hybrida.-. Mixed colors. I foot

Lyehnis, var. - Various colors. 2 feet

The Lichuis are hardy" perennials, showy border plants. Grow freely from seeds or cutrings.

Malope grandifiora. - Crimson. 2 feet.

Malope, var. - Mixed colors. = feet. Hardy annuals of easy culture, showy Hibiscus-like flowers.

Malva, var. - White and purple.

Hardy annuals, large showy tlowers. 2 feet.

Martinia fragrans. - i a riegated. The fragrant Martinia is a beautiful annual, producing a profusion of large Gloxinia like tlowers, blotched and sbaded. Sow seed in May: 2 feet. .

Marigold. -See Tageres.

Mathiola annua alba. - W $W^{*}$ ise.
Mathiola anrua coccinea. - Scarleq

Mathiola annua purpurea.-Purpic.

Mathiola a onua, var.-Mixed c lors. I foot

Mathiola annua. - Biool red. If:

Mathiola annua. - Canarjo ye $=$ I ioot

Mathiola annua. - Duarf W?.: :. The ten - weels' stock or G wi Flower is a balf-haryy asmual. beautiul and fracrant. Sor under glass $\mathrm{Cr}$ on warm borde? ear?'y in Spring, and transfluzt $\mathrm{a}$ rich Eround.

Mathiola simplicaulis, var, - The

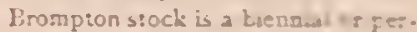
eninial, beatifil culors ard shaces cf collirs. Sir w's more $23=h \mathrm{ng}$ than the ten-weedinci. S win May and when $a b u$ ut 1 wo $i<b=5 h$ हb po? singlyto protect durit gllinter. If : Io Matricaria alba. - White. The "Feverex" is a hardy antua. ci easy culture. 2 feet

Maurandia.-Seelines a $\mathrm{d}^{2} \mathrm{C}$ bers Mesembranthemum crystallinum (Ice Plant) -White. Sar: $\mathrm{i}$ hor. bed and tran<p'an: $t$ t : :ertud-e ef Summer. Highly crmanesul and curious. Fromi:s gliten s.-. Sxce is sumetimes calied Diamo d Platt.

Mignonette. - Ser Reseta

Mimosa sensitiva. - Various colon. The sensitive flate, frum is wy sierious irritabilisy, is very cus es and interesting. Of easy cul re. I fo. Mimmulus cardinalis (Moahey

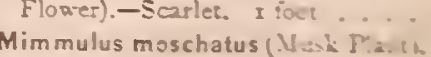
- lellon. sinctes

Annua's, th - gh ciussed is the greenhurse as peremaizi. Sncoed best in moist sod, frer y sha $\mathrm{ed}^{2}$

Mirabilis jalapa. - Ias a $c$ bers. Marvel of Peru, of FLF $0^{\circ} \mathrm{C}$ el. is a very pretly anntil of $1, \ldots+\cdots$ stow:h. The it wers are to $.1-1$ singularly mixed and vencal oc :2e same plant. z ?eet 


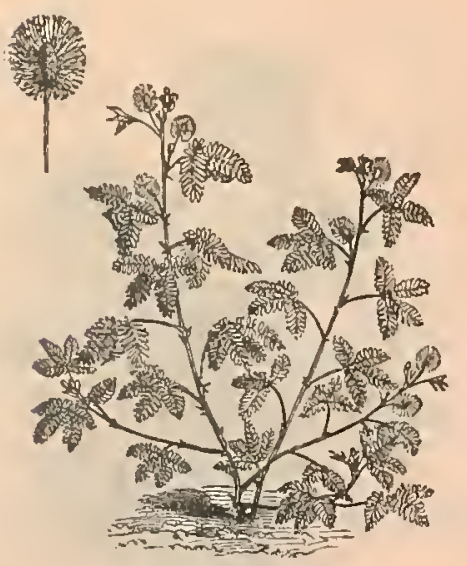

Mimosa (SENSitive PLANT).

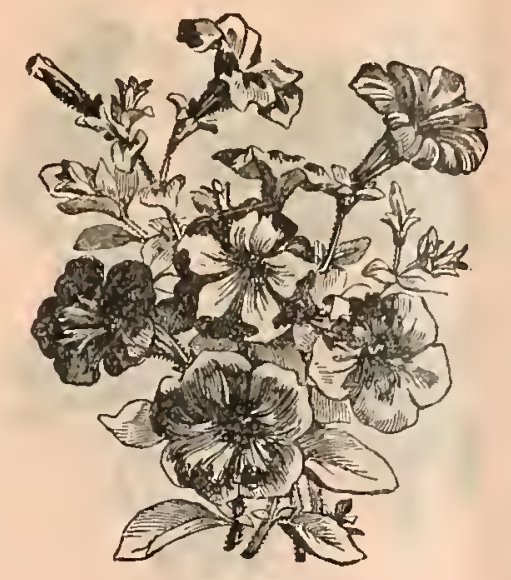

PETUNIA.

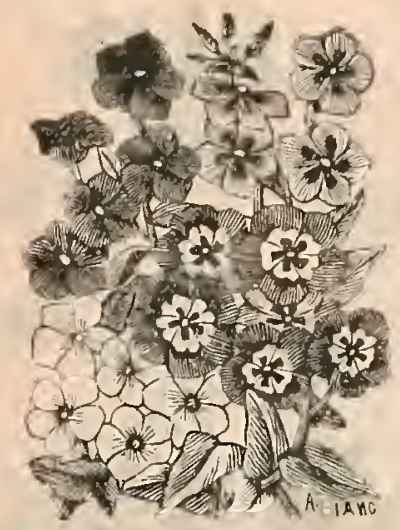

PHLOX DRUMMONDII.

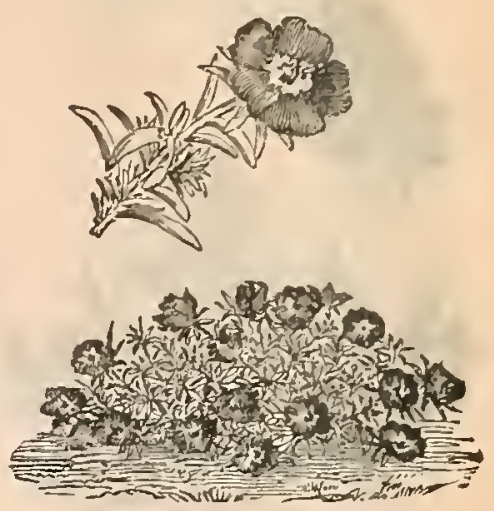

PORTULACA.
Price per Packet, Cts.

Momordica.-See Vines and Climb. ers.

Myosotis palustris.-Blue. The "Forget-nue-not" is a modest, pretty little flower, a favorite with every one. Half-hardy perennial. 6 inches .

Myrsiphyllum.-SeeViries and Climbers.

Nasturtium.-See Tropæolcm.

Nemophila, var.-The Nemophila or Grove Love is a hardy annual, of dwarf habit, producing cheerful. blue, violet and white flowers, suitable for edges of borders. 8 inches.

Nierembergia, var.-Half-hardy perennial, slender branching habit, with yellow-white and $v$ iol et flowers. I foot ...........

Nigella damascena. - Blue. The Nigella, Love in a Mist, or Devil in the Bush, is a hardy annual. Flowers of various shades of blue. Easy culture. 18 inches.....

Nolans.-See Trailing Plaints.

Enothera odorata.-Yellow. Fragrant Evening Primrose is a showy . annual. Easily raised from seed. 2 feet.........

Pæonia officinalis. - Red. Hardy perennial, with bunches of tuberous roots. Sow seed in seed bed in Spring, and plant out in the Fall, protecting with litter first season. After that, little care is required, except to keep ground clean and rich.

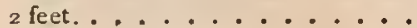

\section{Pansy.-See Vinla.}

Papaver carnation.-Various colors 15 inches..........

Papaver murselli.-Various colors. I5 $_{5}$ inches.........

Papaver pæony-fowered.-Various colors. Is inches.......

$\mathrm{Pa} p$ aver ranunculus-flowered.White. I $_{5}$ inches ......

Papaver bracte atum.-Scarlet.

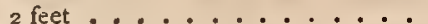
Papaver croceum.-Orange. 2 feet. Papaver orientale.-Ked. 2 feet. .
Price per Packet, Cts.

The first four varieties of Poppies are annuals. The others, Bracteatum, Croceum and Orientale, are perennials, and are raised by sowing seed in the open ground in the Spring or Fall-better in the Fall, as the plant has more time to develop. Will not bear transplanting. Most brilliant and showy flowers.

Passiflora.-See Vines and Climbers.

Penstemon, var. - Beautiful herbaceous hardy perennial plants. The flowers of all the species are bellshaped. Colors scarlet-purple and lilac. 2 feet........

Pepper c elestial, var.-Chinese variety, highly ornamental, bearing abundance of fruit, from one to two inches long, green from the blossom, turning alternately to lemon, golden and scarlet. Annual. 2 feet .

Pepper (Red Cluster or very small Cayenne).-Scarlet. The fruit on the plant, as plentiful as foliage, produces a beautiful effect. Annual. 2 feet...........

Pefunia hybrida.-Mixed colors. 2 feet........... Petunia purpurea.-Purple. 2 feet. Petunia (Belle Etoile).-Neze, white and purple. 2 feet .

Petunia grandiflora. - Large flowered. 2 feet.........

Petunia marginata. - Green edged. 2 feet........ 75

Petu n ia, fl. pl-Double-flowering hybrid. Mixed. 2 feet......

The Petunias are annuals of extraordinary merit and of easy culture, producing a fine effect by reason of the beautiful combination of colors. In the greenhouse they may be classed as perennials. Cuttings from potted plants may be struck at any tims. No plant is of more universal application than the Petunia. In the garden, conservatory or greenhouse it produces most beauti ful flowers in great profusion. Will grow freely in any soil, but the richer the soil the better effect produced.
Phaseolus.-.See Vines and Climbers. Phlox Drummondii. - Various colors. I foot......... Phlox Drummondii coccinea. Scarlet. I foot........ Phlox Drummondii alba.-White. Phlox Drummondii atropurpurea striata.-Dark striped ..

Phlox Drummondii delicata.-Rose, with white centre ......

Phlox Drummondii oculata.White-eyed.........

Phlox Drummondii nana compacta. -Dwarf, mixed.

The Phlox Drummondii, in all its varieties of colors and shades, comprises most elegant annual border flowers, blooming from July to November. Should have rich light soil. The seed may be sown in hotbed in March, and the plants planted out in June, or, when ground becomes warm, may be sown where they are to stand.

Phlox superba, or decussata.Mixed. Phlox superba, or Perennial Phlox, blooms from May to November, producing a great variety of beautiful flowers. Perfectly hardy, requiring little or no protection during Winter. Seed sown in the Fall will produce fine plants the following year. 3 feet .....

Pinks.-See Dianthus.

Polyanthus.-See Primula.

Poppy.-See Papaver.

Porfulaca alba. -White .....

Portulaca aurantiaca.-Orange .

Portulaca aurea striata.-Gold striped ...........

Portulaca miniata.-Vermilion ..

Portulaca splendens.-Mixed colors Portulaca sulphurea.-Sulphur .. Porfulaca Thellusonii.-Scarlet . Portulaca, fi. pl.-Double flowering, mixed colors...

The Portulaca, though one of the most coinmon, is one of the most showy and beautiful of border flowers. The seed germinates freely and flourishes in almost any situation. Does not grow over 6 inches high.
Price per Packet, Cts.

Primula auricula, var.-Half-hardy perennial, produces beautiful flow- . ers of various colors and shades. Sow seed in box early in Spring or outdoors in Autumn; protect well during Winter. Rich soil. 6 inches ......... 25

Primula polyanthus, var. - Hardy perennial, flowers first season. Grows freely in rich, moist, partially shaded position. Start in brixes or pots, and plant out when ground becomes warm. 6 inches ..... Io

Primula sinensis (Chinese Primrose, var.).-The Chinese Primrose is a beautiful tender perennial, cultivated for greenhouse and conservatory decoration. The single varie: ties may be planted out of doors in Summer. Flowers beautifully variegated, spotted and fringed. Sow. seed in shallow pans, with a pane of glass laid over the top to prevent evaporation, or the necessity. of frequent watering. 6 inches. . 25

Primula veris (Cowslip). - The Primula veris, or English Cowslip, hardy perennial, is a well-known favorite. Flowers mostly yellow and red. Propagated by seeds or division of roots. 6 inches .... 10

Pyrethrum aureum(Golden Feather). -Orange. I foot.

Pyrethrum roseum.-Rose.

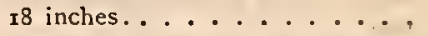
Hardy perennials, easy culture. Pyrethrum roseum is the Insect Powder plant.

Reseda a m e lio rata (Pyramidal Mignonette).-Brown tinted.

ro inches ..........

Reseda aurea (Golden Queen). Io inches.......... 5

Reseda eximea (Parson's White).ro inches.......... 5

Reseda grandifora. - Orange and buff. ro inches........ 5

Reseda machet Dwarf.-Large red. 6 inches......... Reseda odorata (Sweet Mignonette). -Brown and buff. ro inches... 


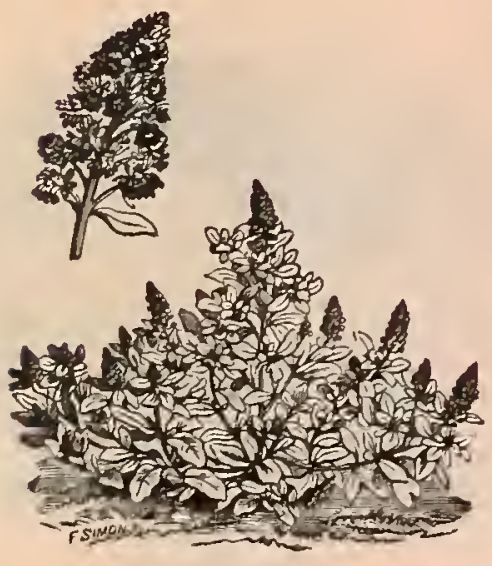

RESRDA (MIGNONETTE).

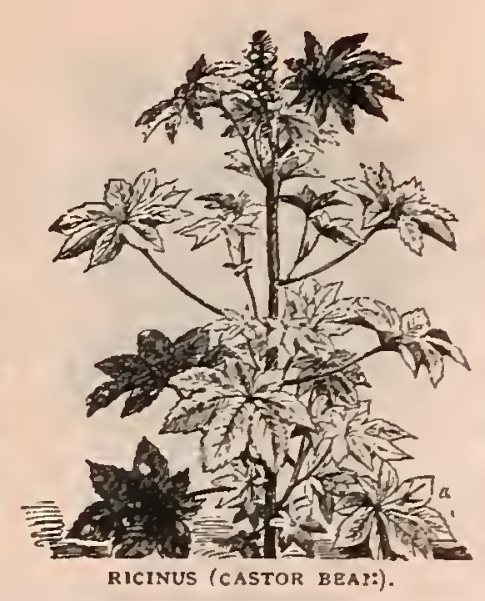

Price per Packet, $\mathrm{Cl}$

Schizanthus, var. - Mixed. The Schizanthus, in all its varieties, is a very pretty annual, blooming freely till late, but attaining lts highest perfection when grown in pots in the greenbouse. 2 feet......

Sensitive Plant.-See Mimosa.

Silene, mixed.-Rose and white. It is a handsome annual horder flower, easy culture. Sow In Autumn or early Spring. Called Catch-fly by reason of a glutinous moisture on the plant. Ifoot........

Snap Dragon.-See Antirrhinum.

Solanum, var. - The Ormamental Egg Plant, white and scarlet, is an annual, presenting a very pleasing effect. 20 inches. .....

Sphenogyne speciosa.-Yellow. A beautiful annual, handsome foliage, free bloomer from July to October. Easy culture I foot.......

Stevia serrata. - White. Greenhouse perennials, much used for bouquets. 2 feet $\ldots \ldots$ Grasses.

Stocks.-See Mathiola.

Sunflower.-See Heliantbus.

Sweet Peas.-See Lathyrus, Vines and Climbers.

Sweot Sultan.-See Centaurea.

Tagetas erecta (African Marigold). -Yellow and orange. $2 / 2$ feet .

Tagetas dwarf.-Striped. I foot.

Tagetas EIdorad 0.-Yellow and Tagetas patula (Tall French Marigold).-Dark brown. 2 feet. .

Tagetas patula nana (Dwarf French Marigold).-Dark brown. I foot .

Tagetas signata pumila. - Iellow striped 15 inches

The Marigolds are showy annuals of easy culture. The flowers of the African variety in its per fection are equal to the double Dahlia. The French, as double as a Ranunculus in appearance and texture, not unlike the richest velvet. Signata pumila is

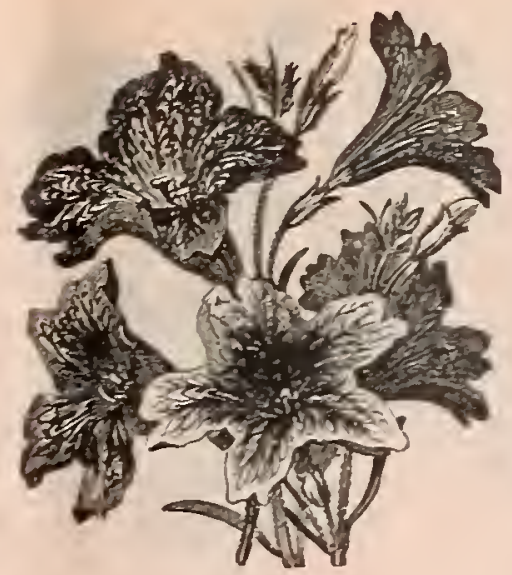

SALPIGLOSSIS

Price per Packet, C

of compact glohulous growth; the flowers, yellow and orange, eover the entire outer surface of the plane. Foliage as fine as $\mathrm{Cy}$ press Vine.

Thunbergia.-See Vines and Climb. ers.

Tropolum.-Dwarf. See Trailing Planes.

Tropaolum.-Tall. See Vines and Climbers.

Verbena.-See Trailing Plants.

Veronica hybrida. - Blue and white. 2 feet...

Veronica spicata. - Blue. Tender perennials. Very pretty border plants. I foot.

Vinca.-See Trailing Plants.

Viola tricolor alba.-White.

Viola tricolor corulea.-Blue.

Viola tricolor,-Lange yellow

Viola trieolor imperialis. - Blotched. Viola tricolor, var. -Mixed

Viola tricolor, var.-Mixed. First. class.

Viola tricolor odorata (Sweet tiolet)

Viola Faust (King of the Blacks)

Viola tricolor, popularly known by the names Pansy, Heart's-ease and Johnny Jump-up, is a halfo hardy perennial, a favorile with every one. Flowers of every con. eeivable combination of beautiful colors and also sepzrate and distinctly marked. 6 inches. Sow out of doors in the Fall: under glass during Winter or very early in tbe Spring. Transplant to the richest soil.

Viscaria, var.-Hardy annual. 6 inches.

Whitlavia gloxinoides. - White and blue. I foot

Whitlavia grandifiora. - Blue I foot .....................

Annuals from California. Fellshaped flowers, from June to Oitober. Requires lighe, sandyloam.

Wigandia caracasana _

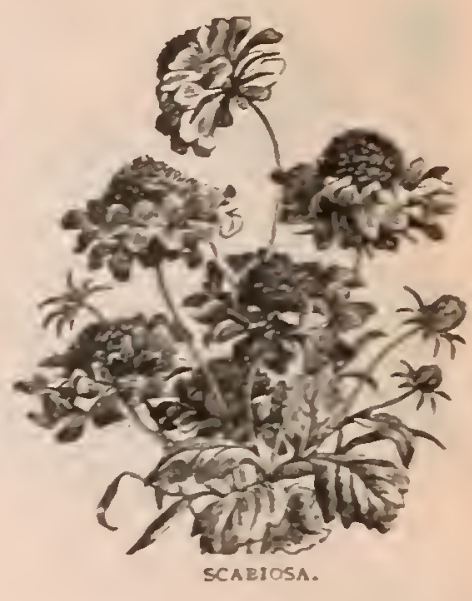

Price ser Packet, Cys.

Wigandia vigieri. -4 feet . . . . so

Half-hardy fereania's : teavifist foliage.

Xeranthemum. - See Everlastiass.

Zinnia elegans. - Double, wile, scatlet, purple and onsze-separase colors. 2 feet

Zinnia, mixed.-A!l eo'ors. a feet.

Zinnia, Dwarf Double. M Mred. 1 t/ feet.

Zinnia elegans is an anmual of robust hahit, blooming from Joly to October. Its beautóstl Dathas. like flowers aclapt it is ans sit. uation in 20y garden. large or small. As a display tinwer it is unsurpassed.

\section{Vines and Glimbers.}

Adlumia cirrhosa (Alleghany" Vire). -Rose lilac. Biennial. 12 feet.. so Ampelopsis veilchi (Japan InyHandy perennial: clings to store or brick. Kap:A climber af:e once started, eovering a lage space in a shor period. Grees in Summer, scarlet in Autusx so feet.

Aristolochia sipho (Muictrara Pipe) -liellow and purple. Harci perennial, rap't frower, laze leaves. Ke्quires plea:y of wa:e: seet.

Calampelis scabra (Ecermocary Vine).-Iender anaual. Bears:-ful climber, with crange fo we: Io feet .

Cardiospermum halicacabum (R:loon linej. - IIzite. Is al anroul of rapis growth foum sech sama is Spriag. Iofee:.

Clematis coccinea. - Searlet. $i=$ fert.............. = Clematis famula (Tirg:-'s Inowe! - II his. 1: iss: 


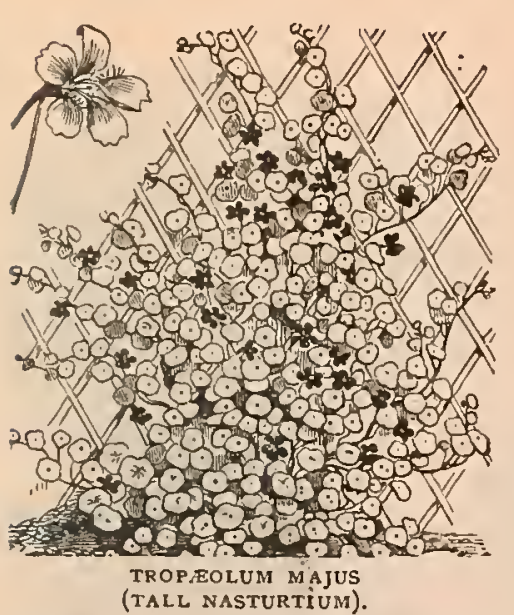

(TALl NasturtiUm).

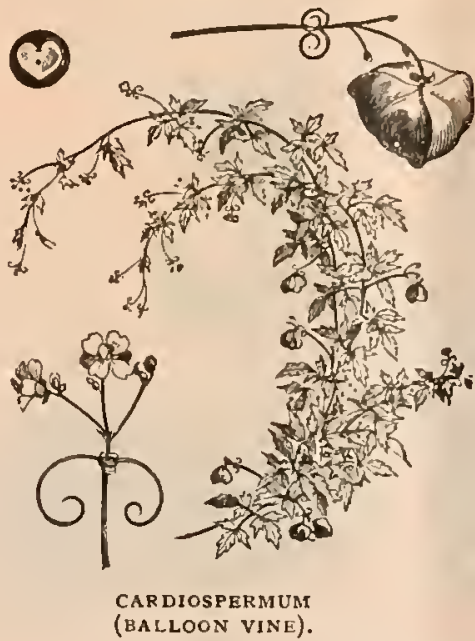

(BALLOON VINE).

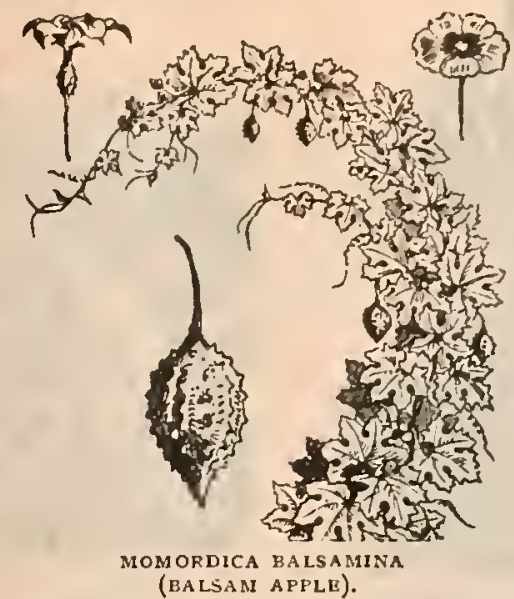

(BALSAM APPLE).

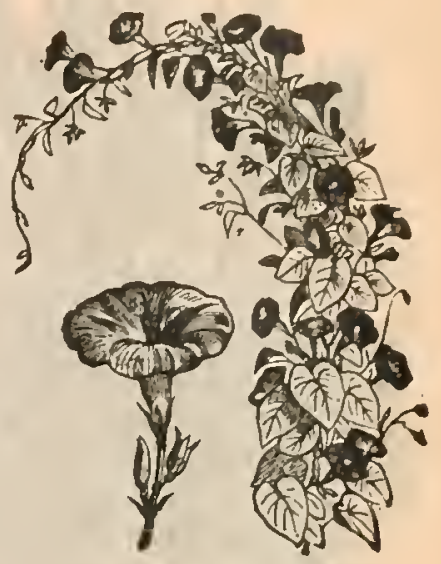

CONVOLVULUS MAjor (TALL MORNING GLORY).
Price per Packet, Cts.

Clematis Jackmanii, - Blue and

White. Iz feet........

The Clematis are hardy perennials, of rapid growth, on trellis or netting. The Clematis flamula is the old variety, Virgin's Bower, or Traveler's Joy. Fine foliage and clusters of small white fragrant flowers. The other varieties are large-flowered and very showy.

Cobea scandens.-Purple. Greenhouse perennial, of rapid growth, bearing great number of bell-shaped flowers. Start the seed in damp sand in a warm place. 15 feet...

Convolvulus major.-Mixed. The Convolvulus major, or Morning Glory, is an annual of rapid growth: large flowers of many colors and shades: suitable for porches or arbors. $x z$ feet. . . . . . . .

Dolichos lablab alba. - White. I2 feet...........

Dolichos lablab purpurea.-Purple. I2 feet . . . . . . . . . . The Dolichos, or Hy acinth Beans, are handsome annuals, producing purple and white flowers on stems or spikes like the Hyacinths.

Hedysarium coronarium (French Honeysuckle). - Red and white. Perennial. 2 feet........

Jpomea bono nox (Evening Glory, Good Night). - Tender annual. 15 feet........... fpomea coccinea (Star Ipomea, or Scarlet Morning Glory).-12 feet . Ipomea grandiflora (Large Purple Morning Glory).-12 feet. . . . . Ipomea noctiflora (Moon Flower).White, zo feet........ Ipomea quamoclit (Crimson Cypress Vine).-10 feet . . . . . . . . Ipomea quamoclit alba (White $\mathrm{Cy}$.
press Vine).-1o feet . . . . Ipomea umbellata.-Yellow. ro feet. I The Ipomeas are amongst the most beautiful of annual running vines. Easy culture, free growth.
Price per Packet, Cts.

Lathyrus latifolius (Everlasting Peas). -Pink and white. to feet ..... Lathyrus odoratus (Sweet Peas).-
Mixed colors, 3 feet ...... Lathyrus odoratus (Sweet Peas). In separate colors. 3 feet..... Latifolius is a hardy perennial. Odoratus is a sweet-scented annual. Plant very early in Spring, and from four to six inches deep.

Lophospermum scandens. - Blue. Tender perennial, bearing bell. shaped flowers. Io feet...... Maurandia barclayana.-Purple. to feet..........

Maurandia, var. - Tender perennial, flowering profusely in the Fall. Succeeds best in the greenhouse. ro feet............

Momordica balsamina (Balsam Apple).-Yellow, ro feet. . . . .

Momordica charantea (Balsam Pear). -Yellow. 10 feet.......

Momordicas are beautiful, halfhardy annuals, producing fleshy, ovate fruit; golden and scarlet when ripe. The fruit when ripe, preserved in spirits, is used to cure flesh wounds.

Myrsiphyllum asparagoides(Smilax). -White. Smilax Vine is a greenhouse perennial, largely used by florists to decorate, make bouquets, wreaths, etc. Plant seeds in a warm part of greenhouse, in a loamy leafy soil. to feet .......

Passiflora, var.-Purple, violet and white. The Passion Flower is a half-hardy perennial; in favorable situations grows vigorously, and produces a profusion of beautiful flowers. 20 feet ........

Phaseolus multiflorus (Scarlet Running Bean).-Annual. to feet . . . Thunbergia alata. - Buff. 5 feet. . Thunbergia alba. - White. 5 feet . Thunbergia aurantiaca. - Orange. 5 feet. . . . . . . . .
Price per Packet, Cts.

Thunbergia, var.-Mixed. 5 feet

Handsone climbing greenhouse perennials, but will succeed in open groutid as annuals if planted in a warm sunny border, peat and loam soil. Start seed in pots.

Tropæolum majus atrosanguineum. -Crimson. 6 feet .......

Tropæolum majus lobbianum.Mixed, perennial. 6 feet. . . . .

Tropæolum majus Schillingii. Spotted. 6 feet.........

Tropæolum majus, var. - Mixed. 6 feet .....

Tropæolum peregrinum canariense (Canary Bird Flower). - Yeliow. 5 feet .............. The above varieties of Flowering Nasturtiums are all annuals, except Lobbianum, which is a tender perennial. Plant seeds as soon as ground is warm. Heavy rich soil suits best.

\section{Trailing Plants.}

\section{Suitable for Vases, Mang ing Baskets, etc. Also for Bedding.}

Abronia arenaria.-Yellow. I foot.

Abronia umbellata.-Rose. I foot . Beautiful hardy annuals, with long trailing stems. Sow seed early in Spring.

Clintonia, var. - White and purple. 6 inches..........

Convolvulus Mauritanicus. - Tricolored. 2 feet . . . . . . .

Convolvulus minor. - Rose, purple and white. Hardy annual, handsome flowers, suitable for vases, hanging baskets and small borders. Single plants at intervals on a lawn have a pretty effect. I foot....
Price per Packet, Cts.

Linaria cymbalaria (Kenilworth Ivy). -Lilac............

Lobelia alba. -White ......

Lobelia erinos speciosa.-Blue . 5

Lobelia gracilis.-Light blue... . 5

Tender annuals, rich colors.

Nolana prostrata (Trailing Nolana). -Blue and violet. Handsome an. nual, stems branching and covered with bell-shaped flowers. Sow seed early in Spring .

Sanvitalia procumbens. - Annual. Forms a mat of deep green foliage, covered with a profusion of golden flowers............

Tropæolum (Tom Thumb).-Mixed. Beautiful dwarf annual Nasturtium.

Verbena, auricula-flowered.-White eye ............ 10

Verbena candidissima. - White. . . 5

Verbena cœrulea.-Blue. . . . . 5

Verbena coccinea occulata.-Scar. let eye.......... ro Verbena hybrida.-Extra selected. Mixed.

Verbena hybrida.-ilixed .....

Verbena striata.-Italian striped . .

The Verbenas are half-hardy perennials. No flower garden is complete without the Verbena. Mostly upright, but when prostrate taking root freely where stems come in contact with the ground. The flowers are continuous, brilliant anđ of all colors.

Vinca alba (Periwinkle). -White.. s

Vinca rosea (Periwinkle).-Rose.. 5

The Periwinkles are perennial, evergreen, trailing plants. Used for vases, covering graves in cemeteries, or bare stady places where grass will not grow. Bear pretty white and rosy flowers. Sow seed in hotbed or greenhouse early in Spring; plant out when gronnd is warm. 


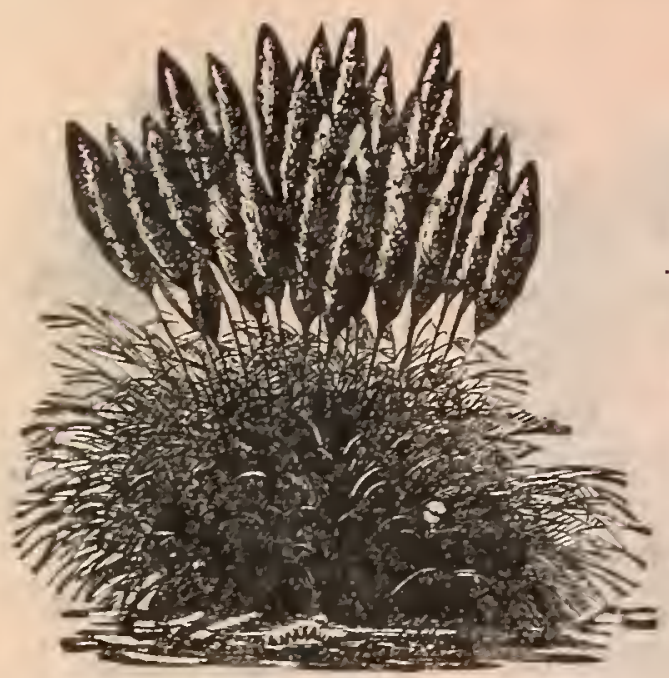

GYNERIUM ARGENTEUM (PAMPAS GRASS).

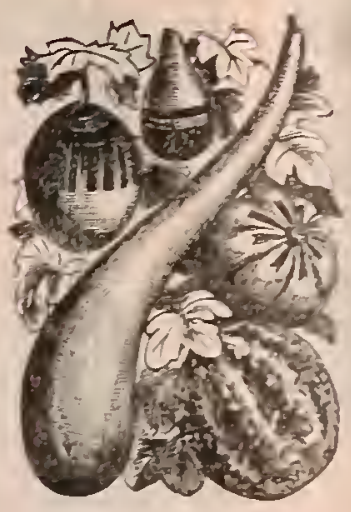

GOURDS.

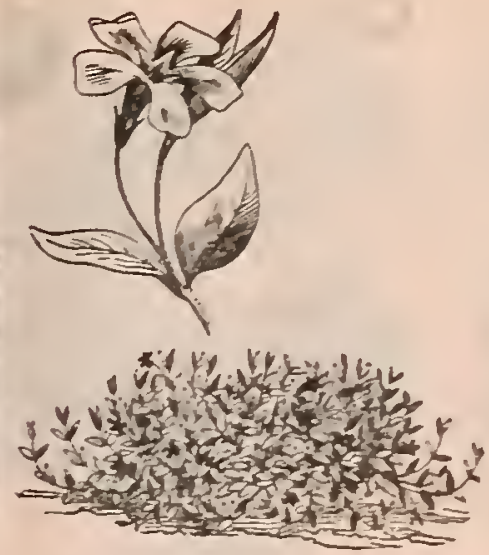

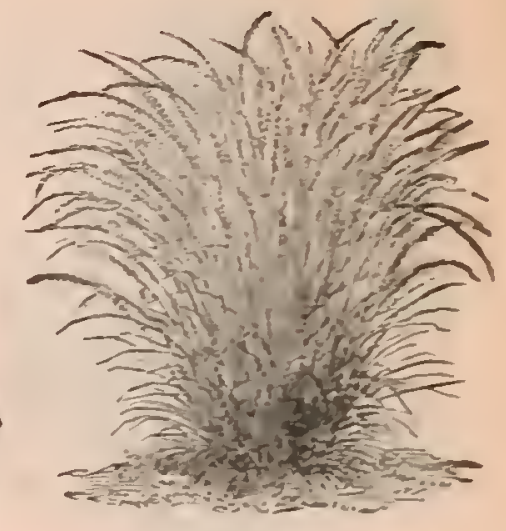

STIPA FENSATA /FEATHER GIASS.

\section{Ornamental Grassses. \\ Ornamental Gourds}

Price per Packet, Cts.

Agrostis nebulosa. -2 feet ..... 5 Agrostis pulchella. -2 feet .

Hardy annuals, graceful foliage.

Arundo donax (Reed Grass)._- 10 feet 5 Single plants present a very striking appearance, Perennials.

Briza (Quaking Grass).-Sow early in Spring: give plants plenty of room. Ifoot. .

Bromus brizæformis. - Perennial, quite attractive, easily grown, start early. to inches .

Coix lachryma (Job's Tears). - Halfhardy annual. 2 feet ........

Erianthus Ravenna.-Hardy perennial; sometimes called Hardy Pampas or Plume Grass. 8 feet ..

Eulalia Japonica.-Hardy perennial, beautiful foliage. 6 feet.

Gynerium argenteum (Pampas Grass). - Perennial. Considerable trade is done witlı Pampas plumes sent from California and sold for decorative purposes. It is a noble plant and can be grown in this latitude. Requires rich soil and plenty of moisture. Sow seed in a hotbed, and plant out when ground is warm. The bulb root must be taken up and kept in cellar in Winter or carefully protected. 8 feet. .

Stipa Pennata (Feather Grass). - Hardy perennial. Used for IInter bouquets. Sow seed early in Spring. 2 feet.

$$
\text { AND }
$$

\section{FRUITED VINES.}

\section{Price per Packet, C}

Abobra viridiflora.-Tuberous-root. ed perennial, bearing small scarlet fruit, presenting quite a showy appearance. 6 feet

Bryonopsis erithrocarpa. - Tender annual with green fr it, changing to scarlet and whice. Pretty foliage. 8 feet. .

Coccinea indica. - Whice. Half. hardy perennial vine, with bellshaped flowers, succeded by oblong red fruit, with white stripes, very pretty: 10 feet .......

Cucumis flexiosis (Snake Cucumber). -8 feet.

Cucum is perennis (Cucumber Vine) -6 reet

Rapid growing aninuals, very pret:y.

Gourds. -

Large Bottle.

Small Bottle.

Dipper Gourd

Dish Cloth or Bonnet Gourd

Mlock Orange, striped. . .

Egg Gourd ...

Mixed Gourds, small.

Mixed Gourds, large

Priceter falle: Cr

The Gourds are annuals, rapid growers, from 10 to 20 feet high, valuable f r covering screet.s cr arbors : sh: uld have moist, rich. loamy soil to atiain perfection. The Bottle and Dipper Gourds are useful when dry for domestic purp ses. The gauzelike covering of the Luffa, Dish Cloth or Bonnet Gourd, is very strong, and can be utilized for many purposes.

\section{Everlasting Flowers.}

Acroclinium.-Mixed, white and rose. 1 foot

Acroclinium. - Mixed, double flowered. foot

Halfhardy annuals of free growth.

Ammobium grandiflora. - It

Hardy annual. Iis silverg white petals and yellow stamens piesent a pleasing contrast. IS inches

Gomphrena globosa alba. - INhaie. I foot

Gomphrena globosa ha geana.Oranse. I foot.

Gomphrena globosa nana compacta. -Red. 6 inches

Gomphrena globosa purpurea. Purple. I foot

Gomphrena globosa, var.-. Mixed. Gomphrena, Globe Amarazhus. Bachelor's Butzon, well-known an. sus!'s of easy cul:use. T precerte for Winter Cecorat a ite firers shou!d be fally ma:-red before teng Eathered.

Helichrysum album. - Pate wb le.

Helichrysum compositum aurea.Larze goiden.

Helichrysum nanum. - D a : f, cou' 'e, mixed

Helichrysum, var. - ${ }^{c}$ agic, E. xed

Tbe He chncurs are anurals, and the mos: showy and atracure of al the Everiasings Scarce'y excelled as a garten oraa ent oz a WW-ter decoratoo. Kequare ret

s il.

Helipterum Sandfordii. - Golcea. A aneal. Produces Liowers do ch-ste:s. U'sed f.: W' We $^{\circ}$ bouges.

Rhodanthe atrosanguinea - Earpis and sile af a Rhodanthe, var. - Mlsed. I frot.

Tender astuals. sea irg are.

Sow seed in t : ked ea $r$ in S,ras, axd d aut past on: : 1 2.] dance: of fiost is past. Floom is the the ¿n'ari semidoukle Suasower.

Xeranthemum album. - II bi:e. if foot

Xeranthemun purpurea. - Furse. ifor

Xeranthemum uperbissirum. -

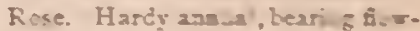

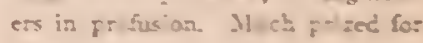
Winte: buquers, = fce:

\section{LANDRETHS'}

\section{"JEWEl Case" of Flower Seeds.}

VER/ ATTRACTIVE LITTLE CASE OF INLAID WOOD.

CONTAINING 20 PAPERS SELECT FLOUUER SEEDS. Each Paper with Colored Ilustration of Flower, and Directions for Culture.

\section{Price One Dollar Each.}

FLOTER SEEDS IN BLLE by the POund or Ounce at Lono Frices.

\section{BULBS OF ALL SORTS.}

We publish a Catalogue and Priced List of

BUI.BS FOR ATTIMIN AND STRING INIANTING.

This List comprises all the usual varieces, th such X" think would be acceptable to our Listomers.

Dutch Bulbous Roots ror Fall Flantins.

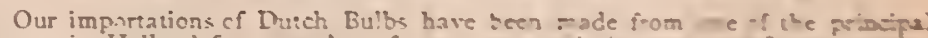

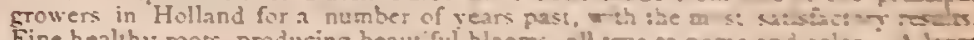

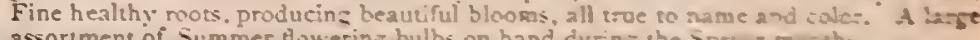

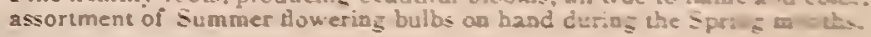




\section{Monthly Operations.}

\section{UANUARY.}

\begin{abstract}
NORTHERN. January is unfayorable to ontdoor labor; in the garden, cepecially, but little cun be clone. Rods for 13eans Peas may be madc ready, Hanuro collected, Compost If eaps fomm and, by the way, compost is beyond all comparison the best shape in which to apply fertilizers to most vegetable crops. Irait Trees pruned; Ifedge: clipperl-those formed of cverurcens not till giter frost has disanpeaped. Asparagus-beds top-dressed preparatory to heing dug when frost has ceaserl. Fotbeds for early forcing mity be made ready. Order' for Linl
dretlis, Seed sliould be sent in early, otherwise new varieties way be sold dretl
out.
\end{abstract}

SOUTHERN. Our calcndar simply aims to remind the reader of what able-thus, for instance, in done it the surrounding circumstances be favormay be sown during the preseut month at Charleston, $\mathrm{S}$. C., and further South, it may le folly to coumit to the earth by reason of the cold, which must neressarily defer such work until a chmnge of temperaturc; or if it be done during thic cessation of extreme cold, the return of Winter weather, or an unseasonable frost, may in a singlc niglit destroy the labor of many dar's. judgment leads him to talic the risk of chances, he may act unon some of the followiug suggestious, if he resides south of tho latitude of charleston.

Radishes sow sparsely from time to timc. Asparagus-beds dress with compost and salt. This latter, thongh an active stimulant, may be safely given in heavy dressings to Asparagus, and has the furtber advantage of destroying weeds. Horse-radisl cuttings put out. Peas sow at intervals; some may be frostcd, but try it again. Read descriptions of approved varie-
ties. Land reths' Garlicst Cabbage, All The Year 'Round, and Select ties. Landreths' Earlicst Cabbage, All The Year' Round, and Select also the Bloomsdale Early Miarket, a wonderfully fine sort for early Summer use; the Reedland Early Drumhead and Flat Dutch Cabbage may uow be sown to come in still later; also the Early Dwarf Flat Dutch Cabbage, a variety which stands the sun, and which we can highly commend as possessing every good quality-thus keeping up an uniuterrupted succession; Canliflower, planted in the Autumn, will begin to head, and may necd slight protection at this season; Turnips for early crops sow. Also Beets sow, also Carrots, Spinacl, Parsley; all of which to be repeater next month; Onions hoe, also other hardy crons planted in Autumn as tbere directed: Lettuce Plants from Fall sowings, transplant: Celery earth up as rcquired; Endive, which should now be in full growth, tie up earth up as rcquired; Endive, which should now be in full growth, tie up to blanch, ill small quantities only, as needed; plant Garlic, Shallots and should be sown. Sow seed of T. T. Tomato. Do uot delay sending iu your order-the only address necessary is Landreth, Philadelphia, Penne.

\section{FEBRUARY.}

NORTHERN. Next month will bring its labors, and we can now only into whose hands this Catalogue is likely to ft is presumed all persons cheap and simple means of enjoyment, a Hotbed, for forwarding tender cheap and simple means of enjoyment, a totoed, for forwarding tender vegetables. Towards the close of this month seeds of Cabbage, Cauliwatch them lest they suffer by frost, or, as is not infrequently the case, from want of sufficient air as the weather becomes milder, when they will ueed also increased water.

We can only speak in general terms of the work which may be advantageously done now, preparatory to the active season which approaches. If tools and implemeuts are likely to be needed, the thouglitful man provides them iu due season; overhauls his stock of Seeds, and makes out a list of those which may be needed, to the end that they nay be in hand before the time of sowing.

The only address necessary is Landreth, Philadelphia, Penna.

SOUTHERN. The time for actire labor is at hand; Peas plant; for unquestionably the the earliest choose Landreths' Extra Early, which is unquestionably the greatest bearer amnng the first early sorts, and is of fine favor. Among the best Peas following in succession are the Premium Gem, Advancer, American Wonder. Beans, Pink Eye Wax, plant. member, highly enriched and well-tilled soil will alone produce good crops of the Cabbage tribe, which embraces the Turnip and Ruta Baga. The Cabbage Plants from previous sowings transplant; and the Lettuce Plants; also sow seed of Golden Curled. Sow Spinach, Radishes, Cardelicious vegetable may be improved by the application of salt or refuse picklc of which heary dressings may be enfely giren. Squashes and Wolons plant. Don't be deterred from ferr of lises by change of temperaure the murdener wlo counts crerv liability will be in the muln, behind luis more cnterprising neighbor. Wxtr. Wirly Achans ani Minuesota Sugar Corn plant for the first rrols. tollow mp with Crosby Sugne, Iandrotk Sugar, Early Mlammoth and Evorgreell, for surcessioll. lilant

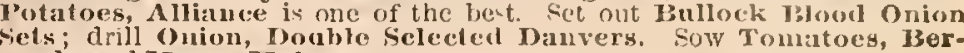
nutla and Money Maker.

Iail your order for seeds to Landreth, Philadcluhia, I'enna.

\section{MARCH.}

NORTHERN. Asparagus sow ; plant roots of the Colossal. Beets, nip, and Farly rolood Turnip sow. Cabbage sow in a sheltered place, not alrcady in hotbad. 'Test Land reths' Carliest, Very Early Wrkeland Early Dromlead. Carrot, Extra Early Forcing, sow. Caullflower-attend to those under glass. Celery sow. Cress sow. Compost prepare. Dung prepare for later hotbeds. Horse-radish plant. Hotprepare. Dung prepare for later hotbeds. Horse-radish plant. Hotto. Minstard sow. Onions pit out as sets-those known as Philadelphia isuttons much the best; get Bullock Blood sets. Parsnips sowBloomsdale is the best. Peas, Landreths' Extra Farly, Advancer, Premium Gem, sow. Potatoes, Early, plant. The Garfield is admirable in every respect. Fadish, Market Gardeners', Summer White, sow. The Wonderful Half Loug, an improvement on the old Long Tonato sow in hotbed. Farly Jcrsey ripens first. T. T. Tomato is best for succession. Turnip, Earliest Bloomsdale, frst in market, the earliest, sow; but generally, be it observed, so far north as Philadelphia, these est, solv; but generally, be it observed, so far north
directions will apply better to April than to March.

SOUTHERN. Southward of Washington, Peas continue to plant. Set dreth' Scarlet, the best in existcnce, and Pink Eye Wax, plant, Labbage Plants from Winter beds transplant, especially Lamdreth' Carliest also Jersey Wakefield. Remember, to have fine head Cabbage and Lettuce, deep culture and highly manured soil is required. Oniong sow, our Extra Early Red. It is remarkably early. Leeks sow. Turnips sow a few; they may succeed. Potatoes plant. Carrots and Pars and Landreth' Earliest Cutting Lettuce, for small salad, sow at least once a fortnight. Parsley sow. Tomatoes sow in warm situation : those once a fortmight. Parsley sow. Tomatoes sow in warm situation; those
from the hotbed may be set ont. Peppers sow close of this month. Water fron the hotbed may be set ont. Peppers sow close of this month. Water Melons, Landreth Boss and Arkansas Traveler, sow; also Extra Early Cantaloupe, Acme and Reedland Giant Muskinelon. Cucumbers,
First and Choice, sow. Okra, Landreths' Long Green Pod, sow, also Squash and Pumpkin. Beets and other root crops sown last month will he advancing; they should be thinned and cultivated; Celery, Paris Strawberry-beds sec out. French Artichokes if slipped and dressed last month, should tave attention.

\section{APRIL.}

NORTHERN. The exact time at which certain seeds should be sown but also on the nature of the soil; if it be beavy, a little delay will rather promote than retard our object-the common sense of each one must be used.

Asparagus sow, or plant roots, if not attended to last month. Wherever practicable, a bed of sufficient size should be made to permit anl ample supply without cutting every feeble shoot which peeps above the surfuce; indeed where space and means admit, two beds should be maintained, and cut alternate seasons. For directions for making an Asparagus bed see article upou Asparagus. Beans, Landreth Scarlet, sow. First in Market is the earliest. Beets, Early and Long, sow. Cabbage, Reedland, Early Drumliead and Flat Dutch, sow freely, that there be enough for
the fly and to plant out in July for Autnmu use. Carrots, Extra Early the fly and to plant out in July for Autnmu use. Carrots, Extra Early sow. Cucumbers, Landreth's' Choice, Landreth'' First, sow in warm spot. Horse-radish plant, if not done. Hotbeds attend to. Leek sow. Lettuce sow in drills, also plant from beds of last Autumu's sowing. Marjoram Sweet sow. Mustard, for Salad, sow. Melons sow; see our new Bullock Blood Sets, and sow Bloomsdale Set Seeds, white, red and

MOBLEY'S POND, GA.-Since I have been planting your seeds I have never failed to have solid heads of Cabbage and Lettuce, something rare in this section.

BLUNT, DAK.-Your Extra Early Red Onion is the best to be seen in this conntry.

LE MIAPS, IOWA.-Your Extra Red Onion did wonders-taking first premium. It is far better in this climate than the Wethersfield. 


\section{Monthly Operations.}

yellow, thickly for sets. Parsley sow. Parsnips, Bloomsdale, Sugar, Land Peas, Early and Late, for a suecession, srw. Potatoes plant liest White, Prussian, Golden Globe, White Summer and Lady Finger, sow for suecession. Salsify sow. Sage sow or plant. Spinacli, isloomsdale, suw at short intervals. Thyme sow or plaut. Toisato sul on border, to sueceed those sown in hotbeds.

SOUTHERN. Spring-sown Cabbage will now be fit to trensplant; in manurewel, if you expect fine heads. The plants set out in February and March will require culture; deep thlage is demanded by the Cabbage tribe. About the middie or litter end of this month, sow Reedland Urunheal Savoy Cabluge seed for plants in be set out in June. Cauliflower and IBroccoli may be sown. Carrots, l'arsnips, lieets, previously sown, are now advancing in prowth, and should receive necesary dale Pearl Onions, set out in the Autumn, should he fit for use. Sow Lceks for Winter use. Turnips sown last month should be hoed and thinnerl. for Winter use. Turnips sown last month should be hoed and thinned.
Draw np the earth to the Potato Vines. Sow Ravlislies, the White SumDraw up the earth to the Potato Vines. Sow Rarlishes, the White Sum-
mer aud Gollen Globe are the best for the season. Let tuce rag be mer aud Colulen Globe are the best for the season. Lettuce mag be
dritled where inteuded to head. Sow Celery, plant mrite Cucumbers drilled where inteuded to head. Sow Celery, flant mrire Cucumbers,
Melons, Squaslies. Study our list of varieties. The fertilizer best adapterl to these vites is eompost prepared the past season. former of decompro manure well-rot ted sod, wood, eirth, cte. It is sufficiently stimulating,
not be likely to burn the plants during dry wenther, and the vines will not be likely to burn the plunts during dry wenther, and the vines will bear better than when rampant from exeiting applications. Okra, Tong Greeti
Pod, sow, if not already in. 'The vigilaut gardencr will keep bis cye uvon the weeds.

\section{MAY.}

NORTHERN. During the pact month the hardier regctalules have bee have been put in.

Beans, Busl, pinnt for succession: Landretlis' scarlet are the best Lima, Carolina, Seck no Further, and other l'ole beans inag a foe planted. Beets, Long, sow. Cabloage, set ont plants and sow sedel in frames, remove glasses. Celery wcel and cow more. Crons which hive failed when tirst sown, repeat sowings. Cnember. Jersevickle, plat falcd when first sown, repeat sowings. Cnember. Jerses rickle, pla stand, thin ont to four inches. Melons plant: the best is Landrethes Pos. and Long light I eing; among Citroms or Muskmelons the lixtra Furly is the tirst to ripen. J'arsnips llin out, if ready.

We have, in former issues of our Catalogres, reemmended $\Omega$ Farmer: Kitehen Garden, where nearly all the preparation of the land may le done
by horse power, and thus most nu ple supples of vegethbles be olitainesl by horse power, and thus most nuple supplies of vegethbles be olitainesl at
all seasons, without hand labor or occupation of time which may not rendily be spared from farm duties.

SOUTHERN. Beaus, Snap, Lima, and Caroliua, plant: also th

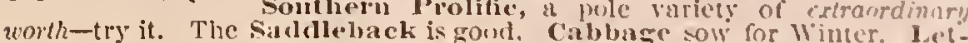

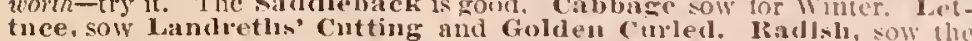

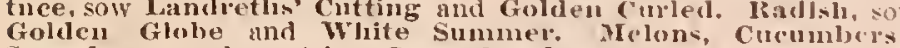

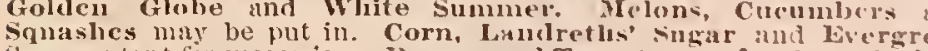
Sugar, plant for succession. I'epper and Tumato sowe for plants ior later erops. Sweet lotato set out in suituble wealher. Where wales is of ea application it may answer to supply it ; otherwise it hardly pays the cost
labor. Under a burning sun, water slonld not he given lircety it is better to apply it between rows of plunts, they will thus suply!y themsilyes without the liability to scald.

At the risk of repesting an oft-lold take, we wnull rem ind ons Souther friends that we of the North timal no omilay of money or labor vicid su
returm, in comparison with the amount expeuded, as that devoted to rourm, in comparise
Kitchen ciarden.

\section{UUNE.}

NORTHERN. The labors of the gardence will mainly consist in the at this seasou will admouish him of the necensity of limely exertion.

The aid of appropriate tools in the culture of crops and the extermination of lleeds need not be commended. Crool implements are indi-peissble

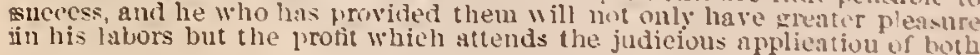

time and labor. In the small garden use the broad hoe freels, as it will sare a vist amount of labor later on asjd we of untold cultural value in morng soil and preserving moisture. The day canot be too hul to hoe wo artrancage

Asparagus-beds keep clean. Beans, Bush or Bunch, plant for succes. sion and cultivate those in growth. IBeets, thin to four inches. I3roccoli, plant out thuse sown in April. Cabbage al-o. ceparially th: sorts which it

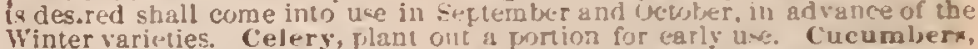
Winter varicties. Celery, flant ont a fortion for carly uv. Cucumbers,
sow successive crops of Cinice all rurky. Curn, landreth sugar,

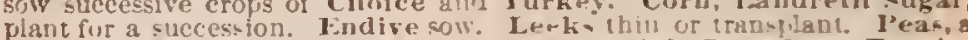

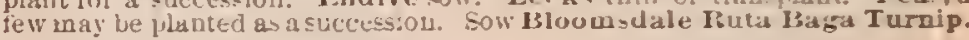
Send jour order for Turuip Seed; sec our list of approved raticlics.

SOUTHERN. Plant Brans; transplant Cabluage, Caulifower ad Autumn heading-but it is

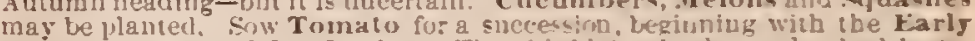

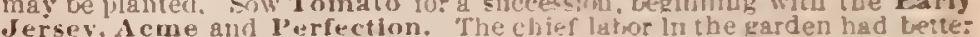
Jersey, Acme and Perfection. The clusef hior lin the garden had bete: in a soutberu clitnate, repay the irouble.

Ifail us your order for Turuip Sects; rou will maat them In Juis and August.

\section{UULY.}

NORTHERN. This, like June, is the month of lator in the za: len weeds are iu rapld growth, plact= are to te sti out, asd rarious matters require attention.

lieans, Iandretha Scarlot, plant for successinn. Whets, the stock. feeding varieties, Long 13lowd, sugat, Mangokl-W'urza. I, may the flanted for stock gs lale as the first of July June l. however, wucb lweite: lieeta.

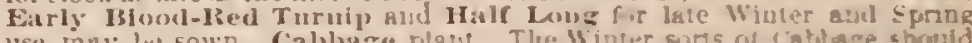

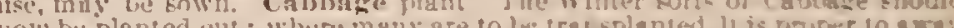

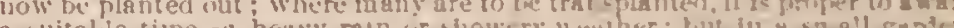

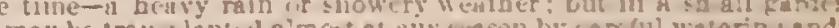
if

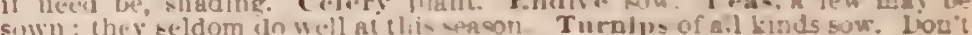
let the weeds olvtain the insatery in the ganden.

Fend us rour order at once that rou may tez prefared to lake adrantage of firorable raus lo sur the serm.

SOUTHERN. Cinder farnmbie condilous, plan: Reans. Transpan:

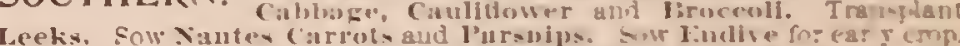

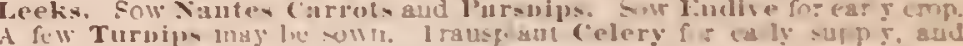

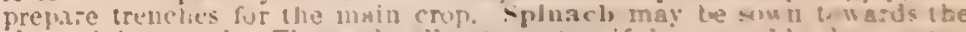

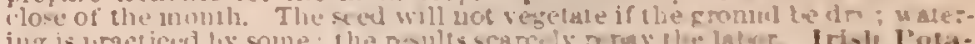

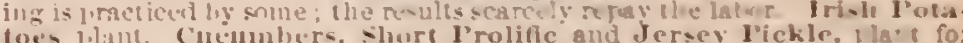

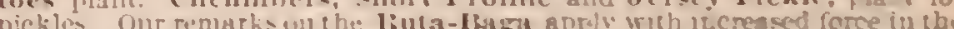
picsles.

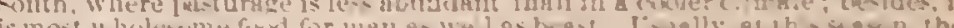

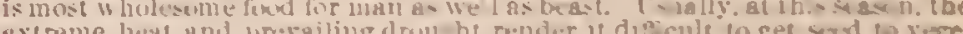

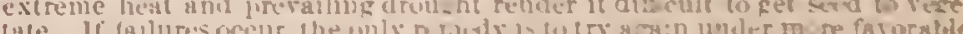

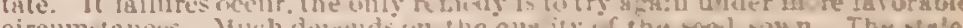

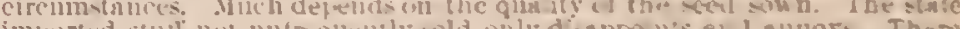

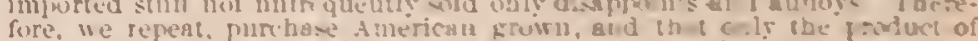

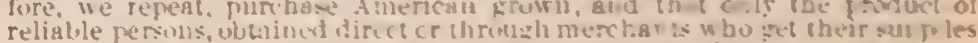

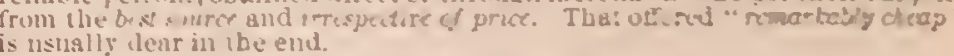

IIave you ordered your seeds for. Ausumn sowing

\section{AUGUST.}

NORTHERN. The wor' of this mont? thes aot ratr ma:eta:Is me

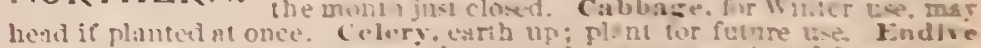

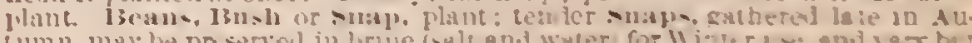

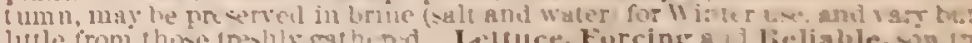

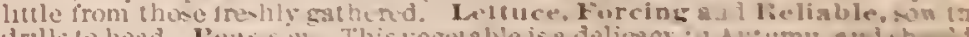

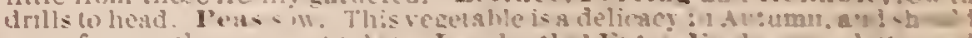

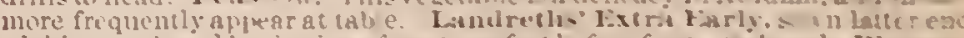

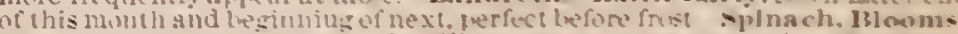

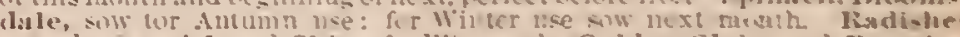
sow, the -panish and Cluiua fi.r Winter, the frolden cileolwe and ITuasian

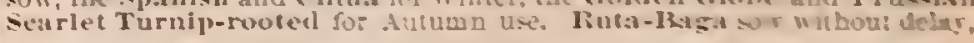

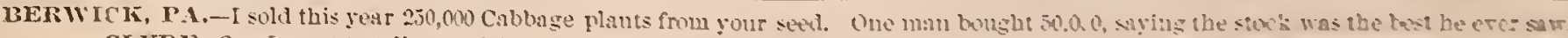

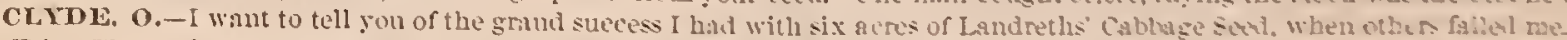

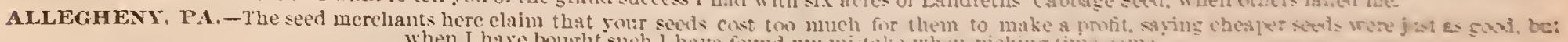
when I have bougbt such 1 bove found ny mistalie when picking time crime. 


\section{Monthly Operations.}

if not already done. Should the gromnel be dry, work thoroughly and sow in the dust; the seed muy vegetate with the first shower. A ruller to compross the soil sometimes promotes vegetation: but there is th is disadvantage-if heavy, dashing raji imnediately ensucs, the ground packs and the sced is last. Large Early Red Top Globe, Southern Suow White Globe and Amber Globe Tumils sow enrly iu the montl, alsis the Swcet Gerinan. don't forget it ; the Earliest Hloomisdale may be sowil until first of september, though it will do well to sow at least a portion earlicr, as at a late day it is difficull to remedy a failurc.

SOUTHERN. Cabbage Secd, Recdland Early Irmmlead, sow to head in November. We also conmend for fimily use, Tandreths" Earliest, Early Jersey Wakeficld, Isloomsdale Early Market, Carly Wwarf Flat Dutch. Broccoli anf Cauliflower sow, and transplant trom an carlier sowiug. Sow Landretlis' Whito Leaved Collards. Onions plant sets for Autumn. Carrots sow Squasl sow. Ruta-Baga sow to make up deficiencies ini July sowing. Turnips for table use sow at short intervals; Bloomsdale Swedo is the longest keeper of al Turnips. Potatoes plant for Winter use. Lcttuce, lorcing, drill for heading. Radishes sow from time to time. Bcets may be sown for the Winter supply. Sow Egg Plant seed protected from hot sun. Seeds di rected to be sown this moith it may, perhaps, be necessary to defer until the next by reason of heat and drought. Let the young gardener be not disheartened, ultimately success will attend persevering efforts, His first care is to provide reliable seeds.

\section{SEPTEMBER.}

NORTHERN. Many and raried are the duties which devolve on the NORTHERN. gardener at this season. Not only do the growing crops demand attention, but seeds are to be sown to provide the neccssary plants for the ensuing Spring Roots are to be divided and reset. Strawberrybeds planted. Cabbage, Landreths' Earliest and Select Jersey Wakefield and Reedland Rarly Drumliead, sow, to plant out in:Autumn where the locality adnits, or box up in cold frrme to keep until planting time in Spriug; the latter end of the month will be time enough to sow in the latitude of Philadelphia; especially sow the Bloomsdale Early irarket, also the Earliest Bloomsdale, as a succession. Turnips, the Early Dut cl

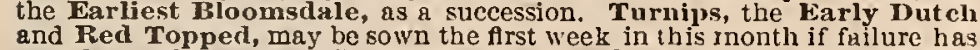
attended earlier efforts. In some sertions the fiy devours the carly sowing. They are less voracirous after the nights become cool and the dews henvy. Celery earth up. Corn Salad, Scurvy Grass aud Chervil sow for Winter salad. Lettuce, Speckled Dutch, sow for Spring planting; the plants to be kept during the Winter iu cold frames. Other good sorts for A utumn sowing are the Bloomsdale Reliable, White Cabbage and Bloomsdale Early Summer. Spinach, Bloomsilale, sow early in month for Antumn use; later for Winter and Spring. Turnips and Ruta-Baga cultivate.

SOUTHERN. The work in the garden has commenced in enrnest. It sown last Reedland Early Drumliead, also the Farly Jersey Wakefield, nay Reediand Early Drumliead, also the Farly Jersey Wakefield, may still be sown. Towards the close of this and the fore part of llext month 8ow Bloomsdale Flat Dutch, Late Mountain and Drumhead Savoy liberally - the flies will have their share. Transplant Caulifiower and Broccoli. Sow more Turnips. Potatoes planted last month will require culture. Onion seed may be sown for a general crop if Philadelphia Buttons or sets to plant are not at hand. Carrots sown now will be fit for use in Derember. Spinach may bc sown from time to time; Endive also. Celery plants need tillage. Lettnce may be sown; Golden Curled and Celery plants need tillage. Tetree Sow Radishes frequently; don't forLandretlis' Forcing are a rare sort. Sow Radislles requently; don't forget Winter
Onion Sets.

Let us advise the inexperienced gardener to exercise his own judgment in much that muy demund his attention. Self-reliance is invaluable, and an thing he will surely learn-that to succeed with any crop the first requi ite is Grood Seed. In vain will he sow, and plant, and water, if he be enticed to purchase seed of doubtful quality by the quntation of low prices. Usually, low prices for seed alway's raisc a doubt. We do not sell cheap seeds.

\section{OCTOBER.}

NORTHERN. The labors of the gardener are raried, and he who neglects duties uecessary to be done loses time not to be regained-the Autumn is upon him. The principal labors are, the protection of crops alrendy grown, transplanting others, and setting out Trees and
Shrubs. Asparagus-beds dress. Cabbage plaut out in sheltered loca- tion and on light land for next season's use. Huets and Carrots store now or enty next month. Lettuce plant ont for next Spring. Potratoex dig. Hloomstale Spinach drill for use iu Spring.

SOUTHERN. Beans planted last month, cultivatc. Cabhage trans IBloomsdale Pcarl Onion Scts set out. This variety is iudeed wourlerful fur early maturity, size and nppearance. Orders for next y'car's seis must he placed with ins the preculing Antuma. Gailic and Escliabots plant. spinacli for Winter use sow. Celery earth up in dry weatlier, and transplant from seed bed for further sipplies; also Lettuce for Suring use.
Radisles sow as required. Articluokes dress preparatory for Winter. Asparagus-beds dress. Strawberries transplant. Peas, Land retho Extra Early, sow. Plant onion Sets, Antumn White Wax, Pearl and 1Bernnula. Set out Onion Sets for Winter and Spring Scullions. Bloomsdale IKale sow for Winter use.

\section{NOVEMBER.}

NORTHERN. The scason for gardening is drawing to a close ; indeed,

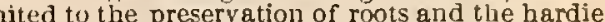
regetables for Winter use, aud such operations as may be preparatory to another season. Now is a good time to transplant Fruit and Ornamental Trees, Shrubbery, etc. On loamy and light land, we prefer decidedly Fall planting, but on heavy soil, or where the subsoil is clay, thus retaining the moisture 11 ear the surface, Spring may be $z$ more favorable seasin; and it is also generally esteemed the best for evergreens. Asparagus-beds Winter dress. Beets dig and store. Cabbages place in safe quarters. Carrots dig and store. Celery earth up finally. Drain vacant ground if needful. Parsnips and Salsify dig and pit for convenieit onions iu sture examine. Parsnips and Salsify dig and pit for convenient access. Frmm 1st to 20 th of this month, according to locality, the Winter supply of Turnips should be
pulled and pitted; read what is said on that point in our pamphlet on Root Culture.

SOUTHERN. The garden work is ample enough to occupy attention. for une fow they will be ready for use in April. For sowing at this season, we recommend Tom Thumb and American Wonder; they seldom rise over twelve inches. are abundant bearers and are, withal. quite early; also Little Gem, the three seem-
ing to be admirably adapted to Autumn sowing in the South, where, on apprehended frost, protectiou may be given; they arc also equally well suited to early Spring planting, for the same reason, and if planted on ground manured excessively high, will yield as much to a given quantity of land as ally Pea known to us. Cabbage, if plants remain, set out. Onion Sets frost kills them it is only a little labor lost. Plenty of Landreths' Seeds are to be had. Try agaiu. Drill Bloomsdale Spinach for Spring use, also to be had. Try agaiu. Mrill Bloom
Rosette Kale aud Forcing Lettuce.

This is the month to get our catalogue and price-list for seeds for the next year.

\section{DECEMBER.}

NORTHERN. Compost prepare. Dung prepare for hotbeds. HotTrench and drain racant ground. Transplanting trees may still be donc.

The most important work in connection with the regetable gardclu this month is to make out and mail to us your order for Landreths' seed. Do it without delay.

SOUTHERN. In the far South, Peas may be sown to succeed those of plants Select Jersey Wakefield and Reedland Early Drumbead to head in January and lebruary. Sow Radishes and Lettuce. Look over the SpinJanuary and lebruary. Sow Radishes and Lettuce. Look over the Spinach, thin it as you collect for dilily use. Onion Sets may still be planted. Endive. Pruue Fruit Trees, vines, etc. Transplant all hardy Trees.

December closes the vear, and if by chance we have dropped a hint of ralue to those whose experience in country life has been less than ours, or induced a better method, or more regular system in the management of farm or garden, we shall be compensated.

One word in conclusion. Don't forget to order Landreths' Seeds early. order them now as you might overlook the subject. Make your order out from this Catalogue. We guarantee the safe arrival of Seeds. See remarks to purch isers, on second page of cover.

CHARLESTON, S. C.-The Landreths' Large York Cabbage is the best early sort; it has never disappointed me for profit. As a Market Gardener I have RóGERSVILLE, TENN. - I have been planting your seeds for nineteen years. No one has done more for the benefit of agriculture than your firm. Landreths' Seeds never fail. 


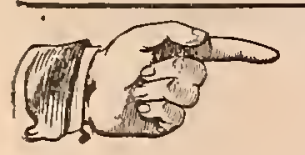

These Prices are Constantly Subject to Fluctuations, and, Therefore, Merely Suggestire. Postage Eight Cents per Pound Extra if by Mail.

\section{ARTICHOKE.}

FRENCH.

Cynara scolymus -Artichaut-Alcachofa-2Irtijjode-Artiskok.

THREE OUNCES OF SEED TO 100 YARDS OF ROW.

Thls plant mar be grown from seed sown when the Cherry is in bloom, or from suckers taken from established plants. If the seed be sown the plat: mas be raised in beds and transplauted. The seedlings or sets should be planted out in rows at four feet apart, at eighteen iuches to the row. Arsicholke in

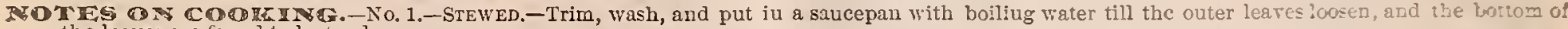
the leaves are found to be tcuder.

No. 2.-Serve with butter sauce, made as follows: Quarter ponnd of butter put in a saucepan, to which add two tabiespons sful of E sur, half pist of water, sult, peprer; stir till it boils, adding the yolk of one egg and a little cream. Stir and remore. Otherwise it will curlle.
No 3.-Cold Artichoke may also be scricd, with French dressing made as follows: Half teaspoonful of salt, smail quautity of yen ler, one tajle spoouful of vinegar, three tablespononsful of olive oil, all beateu well.

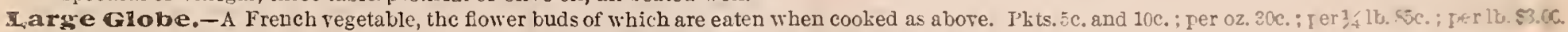

\section{JERUSALERH-TUBERS.}

Helianthus tuberosus-Topinambour-ErbapieI-Namara.

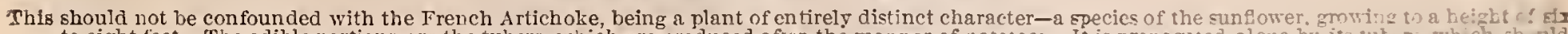
to eight feet. The edible portions are the tubers, which are produced after the manner of potatoes. It is propagated alone by it- tutber, wh ch sh ald be planted in rows of five fect, and one foot ipart in the row. It is perfectly hardy and very persistent irhen once Per bush. \$2.50.

\section{ASPRRAGUS.}

Asparagus officinalis-Asperge-Esparrago- Spargel $\rightarrow$ Asparges.

EIGHT OUNCES OF SEED TO 100 YARDS OF ROW. FIFTEEN POUNDS TO THE ACRE.

Tals plant succeeds best on sandy soil, though reclaimed marsh land, when freed from water, is admimbly adapted to its cultire: the lichere: the so il ibe

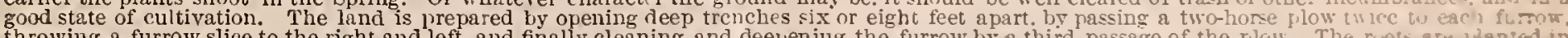
throwing a furrow slice to the right and left, and finally cleaning and deepeniug the furrow by a third passage of the flow. The ruols ase lianied is the bottom of the furrow, at eightcen inches apart, and cuvered by an incl of soil.

Stable manure may be applied in the furrow before the roots are placed, or onl top of roots after they are corered.

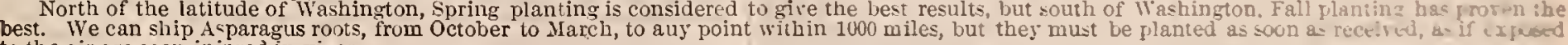
to the air are soon injured in vigor.

If the rows be six feet apart, about 6000 plants are required to plant an acre; if at eight feet apart, 4000 plants are required to the acre

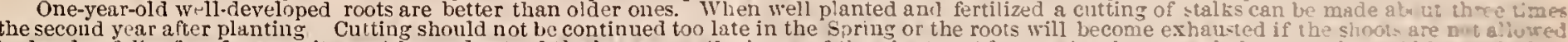
to develop fully, for of course it must be understood the leaves are the lings of the plants. After cutting has cea-ed the gromud should be wark. 7 by

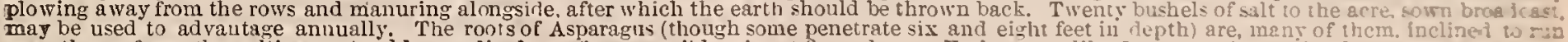

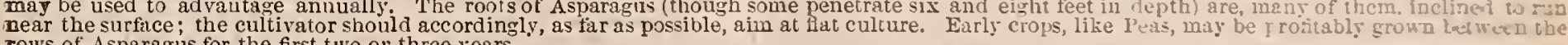
rows of Asparagus for the first two or thrce rears.

A season's cutting covers eight to tell weeks, and profitable cutting contiuues up to teu sears from planting, after which time the thods are oc asgered unprofitable by market gardeners.

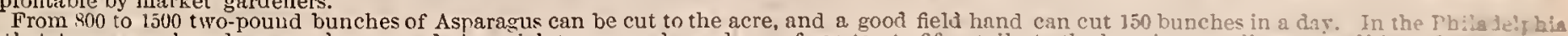
market Asparagus bunches are always made to weigh two pounds, and rary from tent to fifty stalks to the bunch, accoring in

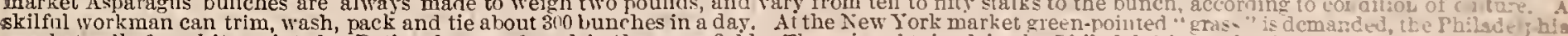
market calls for white-pointed. Both colors are found in the same field. The price obtained in the Philadelphia market by truckers from comm ision men is on an a verage ten cents per bunch, never lower than eight cents, though sometimes the price paid by commis

Asparagns is always in demand, such a thing as the market being seriously glutted with it

One pound of Asparagus seed will produce 2500 plants. The seed may be sown when the cherry is in bloom or ameng the earist Spring, aud is usually drilled iu rows of ten iuches. If the land be friable, fertile aud well culcivates, these seedings con

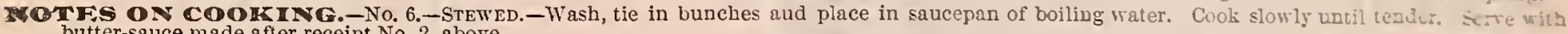
butter-sauce made after receipt No. 2, above.

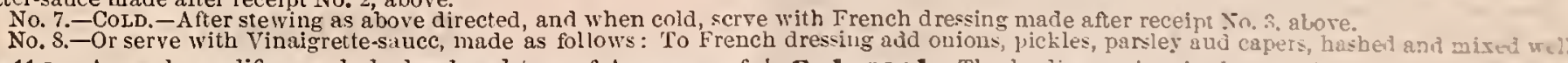

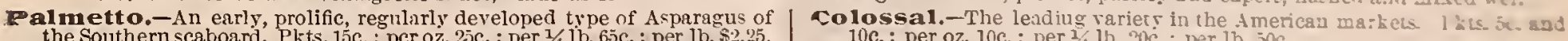

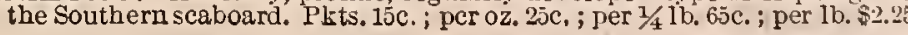

\section{ASPARACUS ROOTS.}

Palmetto. - Per 100, 90c.; per 1000, $\$ 5,50$

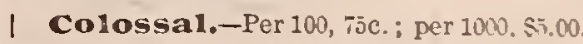

\section{CATTLE BeETS or MANGOLD-Wurzels.}

A family of Beets bred to a large size for cattle feeding. The roots are easily injured by A utumn frosts, and therefore minst be tak properly protected. When first harvested they are acrid aud scour cattle, but after a few months become palatable and saf produce massive roots which, well elevated above the surface, are harvested with the greatest ease and produce double the trei

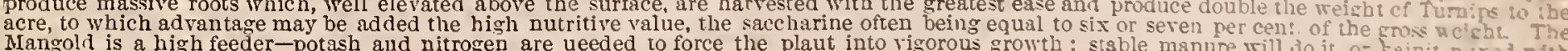
dried meat or fish.

Mangold. Wurzel Yellow Globe.-Similar to the Red Globe excrpt in color. Its single tap root alone enters the earth to auy depth, excrpt in color. Its single tap root alone enters the earth to auy depth,
the bulb so nearly setting on the surface as to render harvestiug simply a matter of liftiug. Pkts.5c. and 10c.; per oz. 10c.; per $1 / 41 \mathrm{lb} .15 \mathrm{c}$. ; per lb. $40 \mathrm{c}$.

sangold-Wurzel Red Globe.-More delicate than the Long Mammoth varieties; more easily hallded ; sEvenTy tons to the acre uot uncommon in England, Fine cattle-feeding roots. Pkts. 5c. aud 10c.;
per oz. 10c.; per $1 / 4$ lb. 15c.; per lb. 40c.

Mangold-Wurzel Yellow Oval-A rariation of the Yellow Globe ; somew hat more productive ; root oblong ; skin goldeu; flesh white. Pkts. 5c. and 10c.; per 0z. 10c.; per $1 / 4 \mathrm{lb}$. 15c.; ; per lb. $40 \mathrm{c}$.

Aolden Tankard Mangold.-A rapidly-maturing root adapted to shallow lands, though doing well on evely soil. This form of cattle-

feediug Beet, by reason of its small root and top. can the caitirated $L$ close rows and an enormous weight produced tw the acre. The -.w tas broad shoulders, smooth rich golden skin, solid st.gar Eesh, an i poltes
footstalk. It has such s slight hold upou footstalk. It has such s slight hold upou the ground ibat it wa the

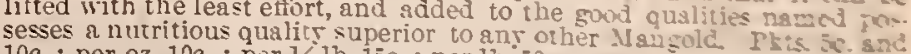
10c. ; per oz. 10c.; per $1 / 1 \mathrm{lb}$. $15 \mathrm{c} . ;$ per $1 \mathrm{~b}$. $50 \mathrm{c}$.

Mangold. Wurzel Mammoth Long Red.-A rer poriac tive variety used for cattle feeding. In Fugland Fomr: rox have tuea grown to

Torbiton Long Glant.-A rert choice and shomr coct of yem.

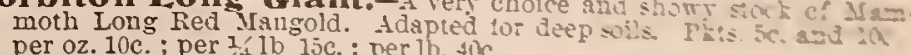

K KANSAS CITY. - "Landreths' First in Market" Bush Bean is a gem, the earliest and teudenst cf all. Also a sp?ens?d hean: 


\section{TABLE BEETS.}

Beta vulgaris-Betlerave-Remolacha-Nothe ober Nuniclrübe-Rödbede. FIVE OUNCES OF SEED TO 100 YARDS OF ROW.

Under a system of horse cultivation drill in rows at two and a half feet apart. If the culture is by hand the rows may be drawn eighteen inches apart. The seed may be drilled in the spring when the Apple is in bloom. Yield 300 to 500 bushcls.

NOTES ON COOKING.-No. 22.-BoILED.-Wash, and boil till quite tender; rub off the skin, quarter and put into a saucepan, with salt, pepper, butter aud a little broth. Let the butter No. 23.-PICKLED.-After boiling, peel and quarter, refresh with cold water, cut in slices and put in a jar half tull of vinegar; add salt, spices, slices of onion, whole pepper, a laurel leaf aud horse radish cut in small pieces. Keep covered.

Extra Early Eclipse.-This newer variety is to a great extent superseding the Egyptian, being two or three day's carlier in development, more attractive in appearance, and of superior quality for the table. The bulbs are perfect globes, blood colored, and develop with astonishing rapidity. The foliage is louger and more vigorous than that of the Egyptian. Pkts. 5c. and 10c.; per oz. $10 \mathrm{c}$.; per $1 / 4 \mathrm{lb}$. $15 \mathrm{c}$.; per $1 \mathrm{~b}$. $50 \mathrm{c}$.

Extra Early Egyptian Turnip.-Growing with the rapidity of a Summer Radish, and consequently maturing in an incredibly short time for a Beet, roots for table use developing in fifty days from germination. Bulbs half globular, or flattened at the poles; roots very slim, skin smooth, leaves red and green, flesh quite dark. This variety admits of close culture, is one of the leading sorts, and will be found very desirable in the family garden and profitable to the trucker. Pkts. $5 \mathrm{c}$. aud 10c.; per oz. garden and profitable to the truck

Bassano, or Extra Early Turnip.-This is, with the exception of the Eoyptian and Eclipse the earliest sort. It is the first in market of the large-rooted sorts; it is globular, sugary, first in market of the large-rooted sorts; it is globular, sugary, flavor and delicacy by any variety. Pkts. 5c. and 10c.; per oz. $10 \mathrm{c}$.; per $1 / 4 \mathrm{lb}$. $15 \mathrm{c}$; ; per $1 \mathrm{~b}$. $50 \mathrm{c}$.

Landreths' Very Early (FoR FoRCING).-We do not know of a better early Beet than this. It is nearly as EARLY as tbe Egyptian and HARDIER. It is not so dark in flesh, but is more firm when boiled or pickled; the LEAF-TOPS are remarkably SHORT and COMPACT, fitting tbe variety for FORCING ONDER GLASS or CLOSE PLANTING on the border. A remarkably fine sort, and distinct from others. We recommend it most highly. Pkts. $5 \mathrm{c}$. and 10c.; per oz 10c.; per $1 / 4$ lb. 20c. ; per 1b. $70 \mathrm{c}$.

Eariy Flood-Red Turmip. - Fere we have the old stand-by, the short-leaved eary millions of homesteads since its introduction over seventy years ago millions of homesteads since its introduction over seventy years ago. Root, broad and fat sile a Turnip, early in maturity and of unexcelled quality. It is the best Turnip-shaped Beet for family use, all things con-
sidered, and we recommend it to all gardeners. Pkts. oc. and 10c.; per Oz. 10c.; per $1 / 4 \mathrm{lb}$. $15 \mathrm{c}$. ; per lb. 50c.

Red Turnip (DewING's). -The New England form of Red Turnip Beet. Pkts. 5c. and 10c.; per 0z. 10c.; per $1 / 41 \mathrm{lb}$. 15c.; per lb. 000.

Improved Blood-Red Turnip (EDMUNDS), - A deep blood variety, slightly oval in form. Pkts. 5c. and 10c.; per oz. 10c.; per $1 / 4 \mathrm{lb}$. $15 \mathrm{c} . ;$ per Ib. 50c.

Philadelphia Early Turnip.-This variety, which we so named and introduced follows very closely after the Bassano; it is neither red nor white, but has alternate rings of lighter or darker pink. Plits. $5 c$. and 10c.; per oz. 10c.; per $1 / 4$ lb. $15 \mathrm{c}$.; per lb. $50 \mathrm{c}$.

Falf-Long Blood Red.-Very desirable. A handsome, wedgeshaped root, growing well under ground; fesh rery dark blood red, skin

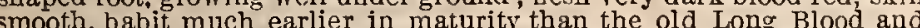
only half its len oth. Recommended highly to market gardeners as a succession to Turnip-shaped Beets. Valuable for Winter keeping or marizet supply, as it retains its solid, juicy character long iuto Spring. Pkts. 5c. and 10c.; per 0z. 10c.; per $1 / 41 \mathrm{lb} .15 \mathrm{c}$. ; per lb. $50 \mathrm{c}$.

Pliladelphia Perfection.-This is similar to the Half-Long Blood-Red. Pkts. 5 c. and 10c.; per oz. $10 \mathrm{c}$.; per $1 / 4 \mathrm{lb} .15 \mathrm{c}$.; per lb. $50 \mathrm{c}$.

Long Blood Red (VERY RICH). - An old standard variety used both for table and for cattle; RESTSTS DROUGHT BETTER than any of the other varieties of Beets : color deep red, flesh very sweet. Grows entirely under ground. Ten to twelve tons can be grown to the acre. Valuable

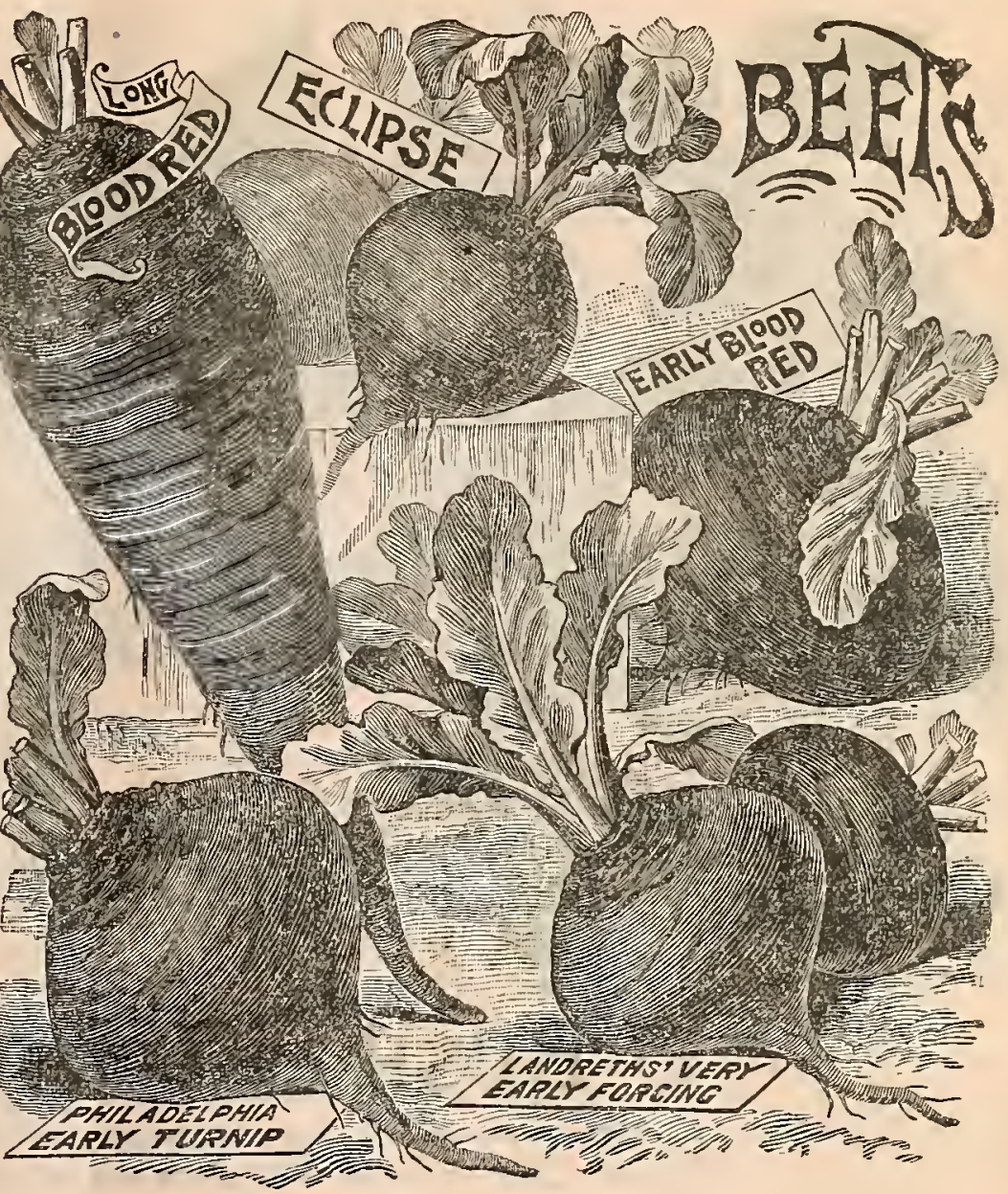

for cattle. Keeps well during Winter. Plits. 5c. and 10c. ; per oz. 10c. per $1 / 4$ lb. $15 \mathrm{c}$; ; per $1 \mathrm{~b} .50 \mathrm{c}$.

Silesian Sugar.-This form of Beet, of which sugar is made, is rapidi growing in favor in this country as a most valuable Winter food for stoc of all descriptions. Fifteen to twenty tons can be grown to the acre under favorable conditions. Pkts. $5 \mathrm{c}$. and 10c.: per oz. 10c.; per $1 / 4 \mathrm{lb}$ 15c.; per 1b. 40c.

Imperial Sugar.-A variety out of which much sugar has been made abroad. Used here for stock feed. Skin cream color, flesh white: \&n average of fifteen tons can be produced per acre. I s high perccntage 0 carbo-hydrates indicates it, as experience has proven it, to be one of the most valuable roots for cattle feeding. Pkts. óc. and 10c. ; per oz. 10c.; per $1 / 4$ lb. 15c.; per 1b. $40 \mathrm{c}$.

Red-Top Sugar.-A white-fleshed Sugar Beet with red crown; very early. Pkts. 5 c. aud $10 \mathrm{c}$; ; per oz. $10 \mathrm{c}$; ; per $1 / 4 \mathrm{lb}$. $15 \mathrm{c}$.; per lb. 40c.

KKlein Wanzleben.-This is the variety of Sugar Beet which the analytical chemists of the German Beet Sugar Factories have united in recommending as possessing the highest sugar-producing qualities, which scientific investigations have been fully sustained by the practical results of sugar making in the factories, as milch as eighteen tons of Pkits. 5c. and 10c.; per. Oz. 10c. ; per $1 / 4$ lb. 20c. ; per lb. $70 \mathrm{c}$.

Swiss Chard or silver Beet.-Greens for boiling are always acceptable. Spinach cannot always be had, and often is tough and stringy. The Silver Beet, on the other hand, is in season from early spring till Autumu frost, and is in finitely superior as a table vegetable to Spring till Autumu frost, and is infinitely superior as a table vegetable to Spinach, Turnip tops, or other greens. Its culture is precisely the same us for the ordinary table Beet. The very young, the entire leaf. We recommend every one who used, or, when verr young, the entire leaf. We recommend every one who Pkts. 5c. and 10c.; per oz. $10 \mathrm{c}$.; per $1 / 4 \mathrm{lb}$. 20c.; per lb. $60 \mathrm{c}$.

\section{THINNING OUT.}

TEXT to errors of too deep or too shallow sowing of Seeds are the errors of thick seeding without corresponding thinning-a neglect of properly thinning out the plants after germination. It is far better to thin out a row of Beets, Lettnce, Carrots or Parsnips, so as to obtaill good specinens at proper disthe plant ater getsing the advantage of thinning oil that we will not waste space dwelling upon it, other than to give the followiug table of suggestive distance to which vegetables the advantage of thinning out that we will
in the private garden should be thinned:
1 in ch-Radishes.
2 inches-Beans, Carrots, Peas, Salsify, Corn Salad.

4 inches-Beets, Kale, Onions, Parsnips, Spinach, Turnips.

3 inches-Beans,

inches-Endive, Parsley.

ROSSVILEE (Fayette Co.), TENN. - Your Cabbage Seed, especially Landreths' Earliest, beats unything ever before raised in this country. 


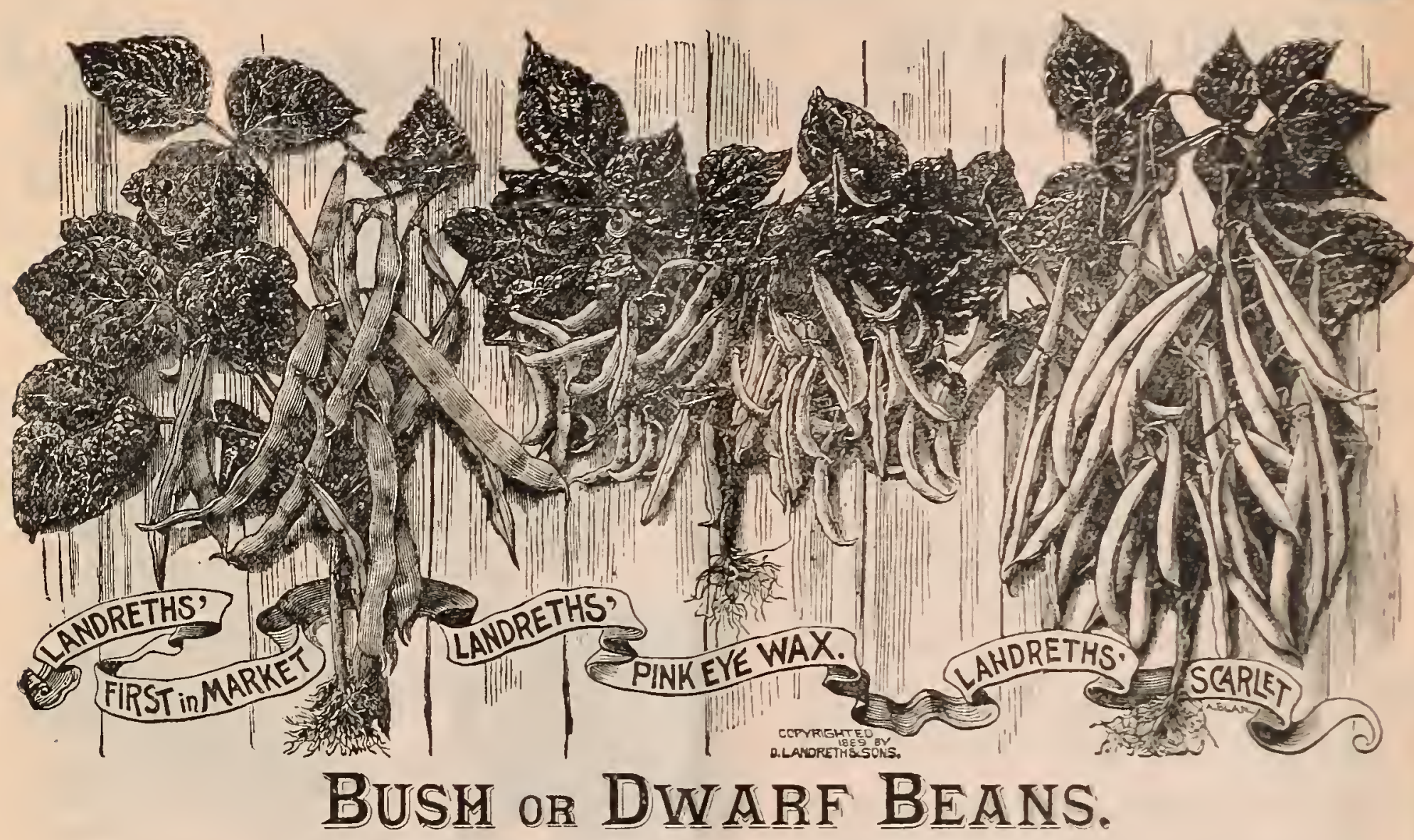

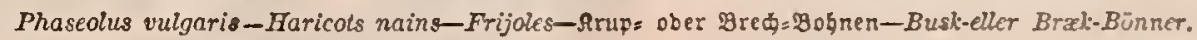

THREE QUARTS OF SEED TO 100 YARDS OF ROW. ONE AND ONE-HALF BUSHELS TO THE ACRE.

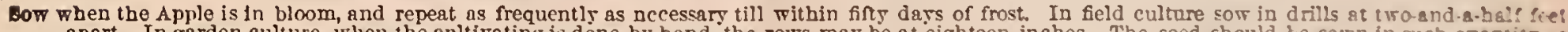
apart. In garden culture. when the cultivating is done by hand, the rows may be at eighteen inches. The seed should ise soira in euch qasari:

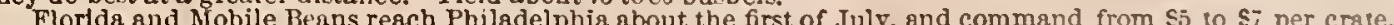
ry quickly, drain through a colander and refresh with cold wister to keep greell; put in a frring-phu, add butter, stilt, pepper and nutmes. DiED BEANS.-NO. 13.-STEWED.-

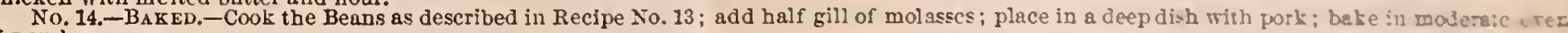
for an hour. bread crumbs.

2. andretis' First in Market.-This is well named, being the earliest Bean in existence, and therefore very protitable to the narket gardener, and desiruble to the private gardener as well. The pods are long, broad, green and very showy, reaching maturity in thirty dars from germinalion, aud the habit of vine productire. Nay be used in three forms-t.10 grcen pods when young and tender, the older pods Pkts. 5 c. and 10c. ; per qt. 40c.; pcr $1 / 4$ bush. \$2.25; per bush. $\$ \$ .00$.

Fxtra Early Red Valentine.-Pods derclop to an cdible condition in thirty-two class from germination. Color of pods, light green and prolifio and quite free from strines, continuing long in ediblc condition. The Vulentine is a variet standard in every gardening district, North, Sonth, East and West, and will always contiulue to be a rers favorite sort both with truckers and private gardeners. It is always salable. because always good. Pkis. 5c. and 10c.; per qt. 25c.; per $1 / 4$ bush. $\$ 1.25$; per bush. \$1.75.

Early Brown Six Weelks, or Mohawle.-Producing edible pods thirty dars after gcrmins

Loms Early yellow Six Weeks.-Phts. 5c. and 10.: per qt. 2 c. ; per $1 / 4$ busls. $\$ 1.25$; per bush. $\$ 1.75$

Clnina Red Eye.-Pkts. 5c. and 10c.; per qt. 25c, ; per $1 / 4$ bush. $\$ 1.20$; per bush. $\$ 4.50$.

Zandreths' Scarlet.-Seed large, kidncy formed, pods golden wax. A surt come to stay. Vine strong, foliage large, broad, hardy. This ralnable scarlet-sceded, ycllow-podded Bush Bean, in some particulars, might be compared witli the Golden Wax, but prodnces much longer,
broader and morc meais pods, is earlier (maturing for the table in thirtybroader and morc meaty pods, is earlier (maturing for the table in thirtyfive days from germination) and more productive, fify to sixty pods to the vine being quite general, and some rines fur exceeding that number.
The pous of this variety may almost be said to be rnst-proof, so free are

ther from the spotting 80 commom amone niber rarieties of fo! ?.en. podded Beans. It is entirely distinct in origin from the folden it $\mathrm{s}$ and entirely differeut in coln and form of the dry seeds fram all oibery the seeds being of tidner form, and of a color ranging from lifht io der scarlet, some almost porple. We could so select the color of the eeeds to breed them all light scarlet, but we find from experience thas sur Scarlet is superior to the whirc.sceded Dwarf Kidncy Wax, which :s Pkts. 5c. and $10 \mathrm{c}$; per qt. $30 \mathrm{c}$. por somewhat resemb.es the Lama

Best of A11. - Vert prodnctire, in shom mads, lons half roend. tor

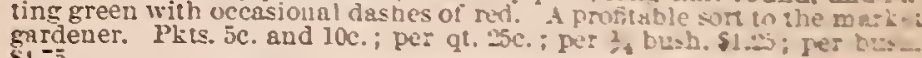
Extra Early Refugee.-Vine mone compact than the Importe

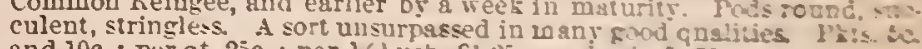
and 10c.; pur qt $25 \mathrm{c}$; per 1 í bush. $\$ 1.25$; ner bub. S1.

White Valentine.-The mols are green mnd, stinclese sncerlez: curred in form, aud of hichest excellence both fur marke: al fama.

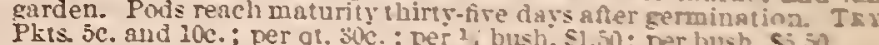
Korticultural I warf. - A busb Bean nsmed after the nsemtisare of the pod in form and color to the pole rarietr of same name.

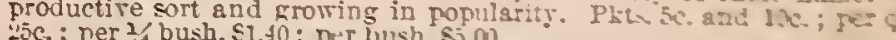

Dvarf Cerman Wax, Black Seed.-Knowa in zan Ina:

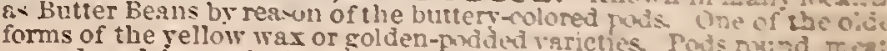
curved and borne in tranches, ready for the table in acuct fors de:

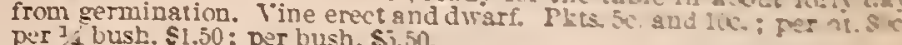


BUSH OR DW ARF BEANS-CONTINUED.

Golden Wax.-Maturing for tle table in about thirty-five days from germination. A flat-podded sort, but probubly tbe best knowil of the yellow wax pod varieties, having become everywhere popular because of its long showy pods, which are nearly twlce the lengtl of the old Blackseeded Wax. Pkts. 5c. and 10c. ; per qt. 30c.; per $1 / 4$ bus: $\$ 1.50$; per bush. $\$ 550$.

Dwarf Kidney Wax.-Seed smaller than Iandreth's Scarlet, kldney" formed, color white with iashes of light purple about a white eye. $\Lambda$ valuable golden-wax podded varicty. Very similar in cdible pod to the Landreths' Scarlet-Seeded Wax, maturing in about tlie same time. Pkts. Landreths' Scarlet-Seeded Wax, maturing in about tlie same
5 c. and $10 \mathrm{c} . ;$ per qt. $30 \mathrm{c}$.; per $1 / 4$ tush. $\$ 1.50 ;$ pcr bush. $\$ 5.50$.

rolnk Eye Wax.-1 new vellow-wax polded bush variety introduced by this firm in 1858 and most highly recommended by us and commended by all gardeners who have tried it. 'Illis Beall cun only be obtained from us. The Pink Eve Wax produces an ercet short vine bcaring fut goldenwax pods, resembling but, beyond coniparison, superior to the Golden Vax. The pods of the Pink Eye are borne in clusters of three or four on a branch, consequently the plunt is far more productive than any other Golden Wax variety. Porls large, round, meaty aud absolutely st ringless. This cannot he claimed for any other variety of Bean, and raises the Plnk Eye Wax to the very first rank. The pods arrive in condition for eating or for shippillg thirty-five days from germination. The dry seeds ale all white cxcepting a pink eye. A peculiar quality of this new Bean is the preservative or long-standing liabit of the pods; that is to sqy, a continpreservative or long-standing liabit of the pods; that is to sqy, a continover a period extending several days beyond that of any otber known variety, a habit of inestinable valle to the market gardenfr, who, with such a lollg-keeping variety under adverse conditions of rain or labor troubles, is liot liable to such serious loss as with a quick-hardening sort. Pkts. 5c. and 10c.; per qt. $35 \mathrm{c}$.; per $1 / 4$ bush. $\$ 1.80 ;$ per bush. $\$ 7,00$.

Detroit Wax.-Fine sort, foliage tinged yellow, vine strong, pods short, fat, broad, light yellow wax, somewhat stringy, quite free from rust. Pkts. 5c. and 10c. ; per qt. $30 \mathrm{c}$.; per $1 / 4$ bush. $\$ 1.55 ;$ per busb. $\$ 5.75$.

Blamarck.-Later than Landreths' Scarlet. A very good Bcan, pods golden wax, sickle or sabre shaped, thick, round, undulnting. somewhat atringy. Pkts. $5 \mathrm{c}$. and $10 \mathrm{c}$. ; per qt. 30c.; per $1 / 4$ bush. $\$ 150$; per bush. $\$ 5.50$.

Tosemite, New.-A golden wax variety, producing very large bold pods of remarkable delisity. Pkts, 5c. and 10c.; per qt. $60 \mathrm{c}$.

Cryatal wax.-Color of poris very light grcen and semitransparent, round, curved, succulent, prolitic, contiuuing long in edib!e condition. Pkts. 5 c. and 10c, ; per qt. $30 \mathrm{c}$; ; per $1 / 4$ bush. $\$ 1.60 ;$ per bush. $\$ 6.00$.

Landretlis' Saddleback Wax.-A new golden-podded wax variety introdu.ed for the first time in tbe Autumn of 1839 . We named it Saddleback by reason of the peculiar form of tbe pods, which on the back are unusually broad, fat and indented with a decided crease. So much flattened on back and front as to have the greatest thickuess or diameter from side to side, which pcculiar quality cannot be pointed out for any other Bean. A novelty of rare merit, produciug edible pods as early as Black Wax, larger, rounder, more pulpy and absolutely stringless; more prolific, hardier than Black Wax or Golden Wax, and unquestionably rust-proof. We are not afraid of praising thls Bean too highly. Pkts. 5 c. aud 10r. ; per qt. $40 \mathrm{c}$. ; per $1 / 4$ busl. $\$ 2.25$; per bush. $\$ 900$.
White Vax.-A desirable Snap-short. Pods broad, flat, yellow, semi transparent when boilcd, of delicate flavor, maturing for table thirty sevel day's from germination, continuing long in edible condlion.
l'kts. $5 \mathrm{c}$. and 10c.; per qt. $30 \mathrm{c}$.; per $1 / 4$ busb. 81.60 ; per busb. $\$ 6.00$.

colden Fyed Wax.-Yellow podded and showy-good sort. Pktt. 5c. und 10c. ; per qt. $30 \mathrm{c}$; per $1 / 4$ bush. $\$ 1.60$; per bush. 86.00 .

Refuxce.-Tlils Bean ln some sections is known as the Brown speckled Valentine, in other dlstricts as " 1000 to 1 ," by reason of lts prolific cbarac ter. It matures green pods for table use in forty days from germination. Pois round, light greeu, waxy, tender and of finc flavor. Of high repu tatiou in some districts, leading all other varietics in quautity planted. It is a favorite Bean for salting and canning. A strong growing ville, requiring fift per cent. more room than the Red Valentine, not so erect in habit of growth. Pkts. 5c. and 10c.; per qt. 25c.; per 1/4 bush. \$1.20; per bush. $\$ 1.50$.

Golden Pod Refugee.-A variety having a pod of the character of the Refugee, but golden wax instcad of green. Pkts. 5c. and 10c.; per qt. $30 \mathrm{c}$.; per $1 / 4$ bush. $\$ 1.60$; per bush. $\$ 6.00$.

Landreths' Paris Canner Bean.-Green pol-cmerald green. Iutroduced by us in 1886 and found to possess tbe followiny desirabio qualities for canning-factory use. 1st. Vigorous constitution of plant, the foliage being in color a deep green and resisting tbe hottest sun. 2d. Immense productiveness, the yleld in pods being more than double that of other Bush Beans, while tbeir small size adapts them for canning and pickling. 3d. Green seeds, the soft beans retaining their green color till they become fully ripe, and like Invicta Peas do not show age if delayed iu picking. 4tb. Tbe seed being so small and the habit of tbe plant so busby that one bushel of seed will cover as much ground as two bushels of ordinary beans. Valuable for foreing on account of surpass. ingly productive habit. The Bean used in France, put up in glass and tin. $A$ bush variety growing to a hcigbt of twelve to fourteen inches, weil branched. Foliage strong and dark, and resisting the most intense heat. Exceedingly early to produce marketable pods of accepted adapt. ability for canning and pickliug purposes, by reason of their great length, narrow breadtb, deep color and solidity. Marvelously productive of pods borne in pairs; so productive as to exceed anything in the Bear fine we have pars; The dry seeds are small and of ligbt green color. Pkts. $5 \mathrm{c}$, and 10c.; per que dry seeds are $80 \mathrm{c}$. ; per $1 / 4$ bush. $\$ 2.25$; per bush. $\$ 8.00$.

Dwarf Carolina.-Secds similar in shape to tbe Sewee. Some seed meu call this Dwarf Lima. Pkts. 10c.; per qt. $45 \mathrm{c}$.

Royal Dwarf.-A kidney-shaped white Bean for Winter consumption in the dry state. Pkts. $5 \mathrm{c}$. and $10 \mathrm{c}$; ; per qt. $25 \mathrm{c}$; per $1 / 4$ bush. $\$ 1.20$; pes bush. $\$ 1.50$.

White Cramberry.-A field Bcan, grown for commercial purpose. and Winter use. Color white. Form nearly round. Pkts. 5c. and 10c.; per qt. $25 \mathrm{c}$. ; per $1 / 4$ bush. $\$ 1.20$; per bush. $\$ 4.50$.

Navy-A grocery Bean used in Winter for bakiug. Pkts. 5c. and 10c.: per qt. 25 c.; per $1 / 4$ busb. $\$ 1.20$; per bush. $\$ 4.50$.

\section{BROCCOLI.}

ONE OUNCE OF SEED TO 100 YARDS OF ROW.

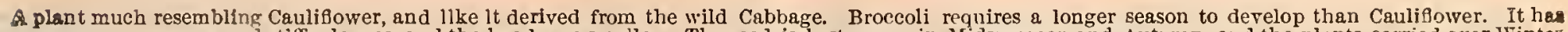

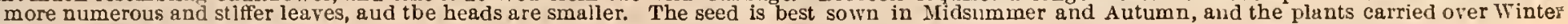
for cutting in the Spring.

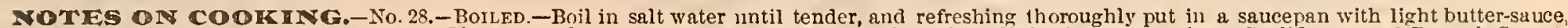

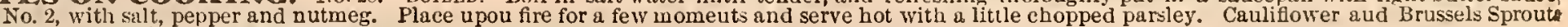
may be treated in the same mauner. 
P. $7+8$.

Battonn $1 / 4$ or uare of packe misaing alco $833 \% 34$

$$
\begin{aligned}
6 / 5 / 72 & \text { Di.C } \\
& \text { NAC }
\end{aligned}
$$




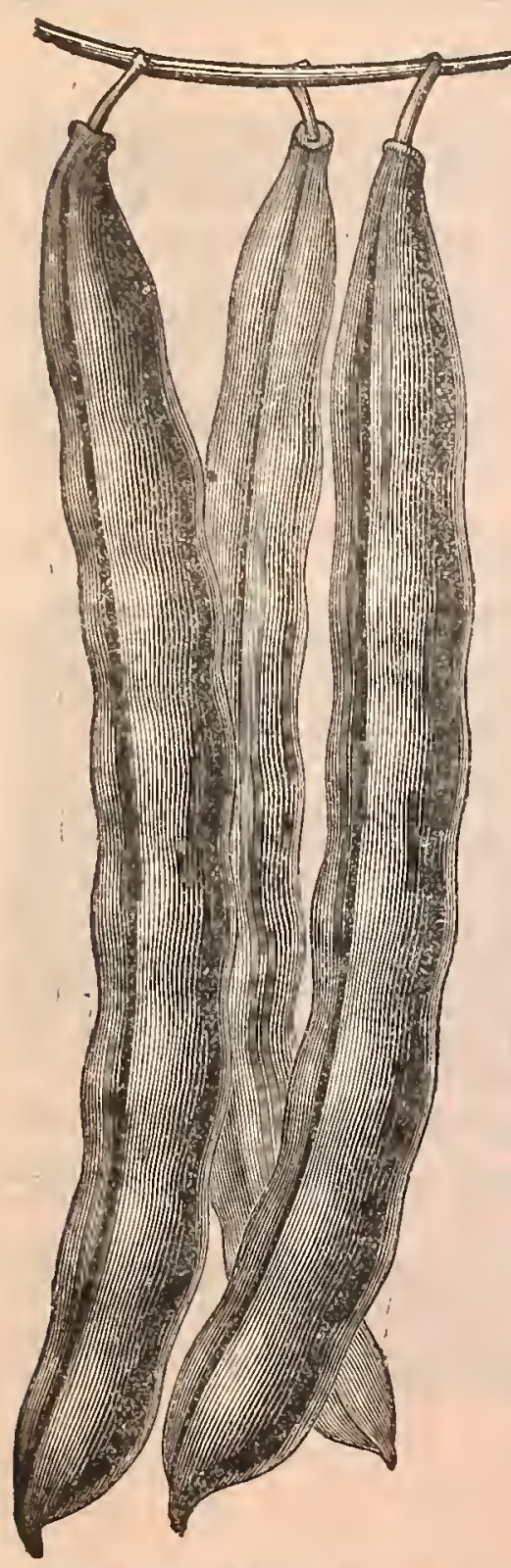

CREASEBACK OR FAT HORSE BEAN.

\title{
POLE oR RUNNING BEANS.
}

\author{
THREE PINTS OF SEED TO 100 YAROS OF ROW. FIFTEEN QUARTS TO THE ACRE.
}

Plant when the Apple is in bloom ; set poles four by four feet; tie up the tendrils as often as necessar. Io preten: Bean poles from blowing down unite them by strong cord; or better, dispense with poles and we wise nettizg

Creaseback or Fat Morse Bean.-Earliest Pole Bean in cultiration, ezceedingly productire and of fine quality. Pkts. 5c. and 10c. ; per qt. 30c.; per 1/4 bush. $₫ 1.80 ;$ per bush. $\$ 6.00$.

Southern Prolific (NEW YORK STOCK). - Matures in serenty dass from germination. Pearing till frowt,

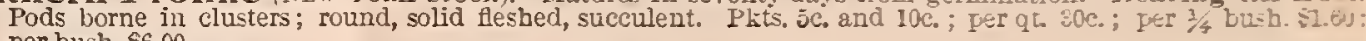
per bush. $\$ 6.00$.

IKentuchy Wonder.-A large, green-podded, early prolific sort. Tender, solid and stringless ushen rerg young. Plits. 10c, ; per qt. $70 \mathrm{c}$.

reed-Speckled Oval-Seeded Cut-Short Cornfield.-This is a climbing green-fndid Bean. used in the South for planting to Com, and bence known in some localities as a Cornfield Bean. of wh bich then are many rarieties, this being one of the best. It is rery productive, and for table purfoctes, lised $a=a$ snag, is of excellent quality; pods green, half round and succulent. Plis. כ̧c. and 10c. ; per qt. Guc.

New White-seeded Runner. A noreltr of high merit. The drs seeds are white, fat. liriner chavel The pods, when in edible condition, ranging from green to golden and bone-rbite: succeed nis teet on bears ground. They are absolutely stringless, brittle as pipestems, long and half round. Plits. 10c.; Jer qi. sice.

Golden Cluster Wax.-A splendid sort, exceedingly productive of large golden wax pods, Zorse in cluc:e:s and continuing in bearing until stopped by frost. $\mathrm{Pkts}$. 10c. ; per qt. $80 \mathrm{c}$.

Tall Cerman Wax, 181 lack Seed.-A good Enap-short. Pods flat, wax., maturing in serentr-fire days from germination. Pkts. 5c. and 10c.; per qt. 35c.; per $1 / 4$ busL. $\$ 1.70 ;$ per bush, so. 50 .

White Dutch or Case Inife. - An excellent Bean, used either as a Snap-shor when rer. roung. sbe". 60 as the Lima when more largely developed, or for soaking when dry in Winter. Pkis, $3 c$, and $1 \mathrm{r} ;$; por oL $30 \mathrm{c}$; per $1 / 4$ bush. $\$ 1.60 ;$ per bush. $\$ 6.00$.

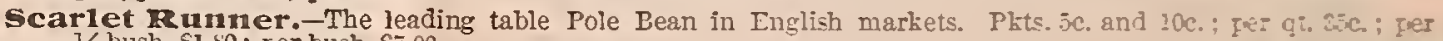
$1 / 4$ bush. $\$ 1.80$; per bush. $\$ 7.00$.

Morticultural. A showy Bean maturing in eighty days. Pods green, dashed with red. Phics. ic. azd loc. per qt. 30c.; per $1 / 4$ busl. $\$ 1.60$; per bush. $\$ 6.00$.

Giant Wax, Red Seed.-An acquisition among the Pole Beans. Pods lons, clear wary rel? w, succulech tender, fine flavor. Pkts. 10c.; per qt. $45 \mathrm{c}$. ; per $1 / 4$ bush. $\leqslant 2.50 ;$ per bush. $\$ 9.00$.

Ca rolina or Servee.-A small rariety of Lima, more easy of regetation, more rigorous in c.owth, earlier

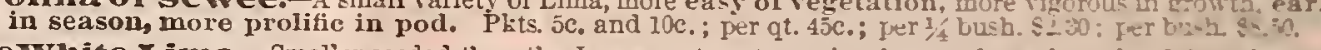

L' re WVinte Iima.-Smaller seeded than the Jersey, not so strong in vine nor large in rod. Otherwise excel. lent in quality. Pkis. $5 \mathrm{c}$. and $10 \mathrm{c}$; ; per qt. $35 \mathrm{c}$.; per $1 / 4$ bush. $\$ 1.70 ;$ per bush. $\$ 6.50$.

Large Jersey I.ima.-Natures ninety days from germination. Yield about eighty bushels green fouls re:

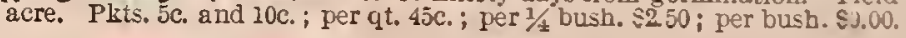

\section{ENCLISH BEANS.}

Early Mazagan, Long Pod.-Xatures in fifty days after germination. Plits. 5c. and 10c: pe: qi the; per $1 / 4$ bush. $\$ 2.25$; per bush. $\$ 5.00$.

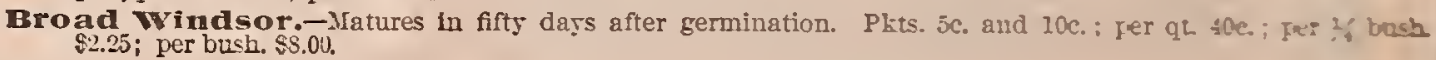

\section{BRUSSELS SPROUTS.}

Chou de Bruxelles.

ONE OUNCE OF SEED TO 100 YARDS OF ROW.

A variety of the Cabbage family, possessing the peculiarity of bearing upon its stem or stalk from fift to one hundred bucs resembling mirinari. Culbast beads. The leaves composing these heads resemble Savoy Cabbage in their crumbled texture and also in their color. The beads or bads. fal ane

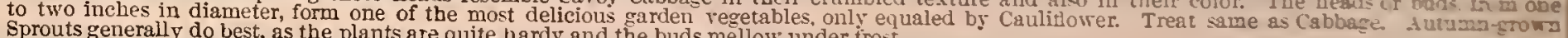
plants are quite bardy and the buds mellow under frost.

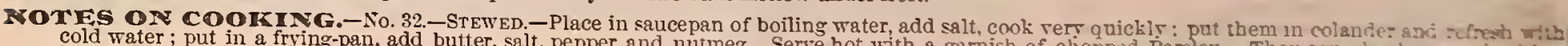

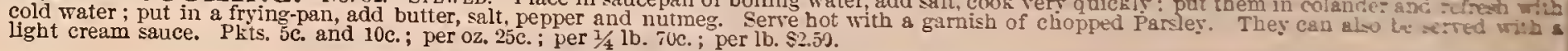




\section{CAULIFLOWER.}

Brassica oleracea bolrytis-Chou Fleur-Colifor-Blumenlohl-Blomkool. ONE-HALF OUNCE OF SEED TO 100 YARDS OF ROW.

This delicious plant, like Broccoll and French Artichoke, is distinguished from other table vegetables by producing edible flower heads. By long years of selection and culture of some accidental natural variation of this plant of the Cabbage family discovered in the Middle Ages, the flowers of the Caulifower have been, to a largc extent, rendered abortivc, and the to form a half globular compact crown or head which, when cooked, is tender as marrow, and the choicest of all esculent vegetables. Varying with cilmatic and soil conditions, the seed is sown at all seasons. In hot beds at close of Winter, out of doors when the Apple is in bloom, again when the Oak is in full leaf, again at Midsummer and again during W'inter under glass. The young plants are treated the same as Cabbage, and the larger plants require the same rich fertilization and culture-indeed the larger plants ru as only thosc Caulitiowers are good which are grown quickly. We offer only seed of the highest quality. The early varieties quickly. We offer only seed of the highest quality. The early varieties are most likely to succed in the bands of inexperienced growers. "Sow frame," protected by sash from severe frost during the winter, and transplant into deep and very rich ground as soon as frost ceases. Handglasse or boxes placed over them at night, when they are put out, are aserul. It should be observed, however, that success is very uncertain in dry localities. In Pennsylvania the Cauliflower seldom heads well unless under class, or in cold frames. But there is little dificulty in having fine cauli gowers when planted in rames under glass, at close of Winter, so as to in Autumn, and are sown at the same time, and managed similarly to Cabbage. They do best in localities where the atmosphere is damp and saline, bage. They do best in localities where the atmosphere is damp and saliue, well-tilled, well-watered soil, and that it can hardly be overfed.

TONES ON COOKING.-No. 59.-BorLED.-Wash, place in a ressel with cold water and boil, empty, refresh, and boil again; when nearly
done drain and add a small quantity of milk and butter, and cook until tender. Serve hot with cream aud butter sauce as described under Recipe No. 2 .

No. 59.-A U GRATIN.-Boil as directed in No. 22. Place tablespoonful of butter in frying pan, oughly and add one-half pint of milk; stir continually until it boils, when ad d one-half teaspoonful of salt and four tablcspoonsful of grated cheesc, Parmesan is best, pour this over the boiled Cauliflower, sprinkle with brea No. 60.-B.AKEn.-After cooking as described in No. 22, place the Ca
and a little grated Siriss or Parmesan cheese and small pieces of butter.

Mandreths' First.-In this variety is found the perfection of a combined early and large Cauliflower, not onl y equal to any in quality. but a bined early and large Caulifower, not onl equal to any in quality. but a certain cropper. Its exceedingly short stem designates it as the best adapted for forcing under glass, and it will be found the most profit-
able for the field. About 12,000 plants may be set to the acre. Leaves short and broad. Head large, compact and pure white. Pkt. 50c.; per oz. $\$ 6.00$.

Eariy Snow-IBa11.-A rariety of widest celebrity, by reason of its reliable qualities of productiveness, color flavor and keeping in condition. Early, good size, pure white, medium length of stalk. Leaves long and narrow. The variety of which most seed is sold. Pkt. 40c.; per ox. $\$ 3.50$.

Delect Early Dwarf Erfurt.-For some years past one of the standards. Of highest excellence, and for field culture not much surpassed by any type of newer name. Some so-called new varieties appear to be identical with Select Erfurt. Pkt, $40 \mathrm{c}$.; per oz. \$2.50.

Extra Ear1y Paris.-One of the earliest varieties in cultivation. Very dwarf large white compact heads, of finest quality. Highly recommended. Plit. 10c.; per oz. \$1.00.

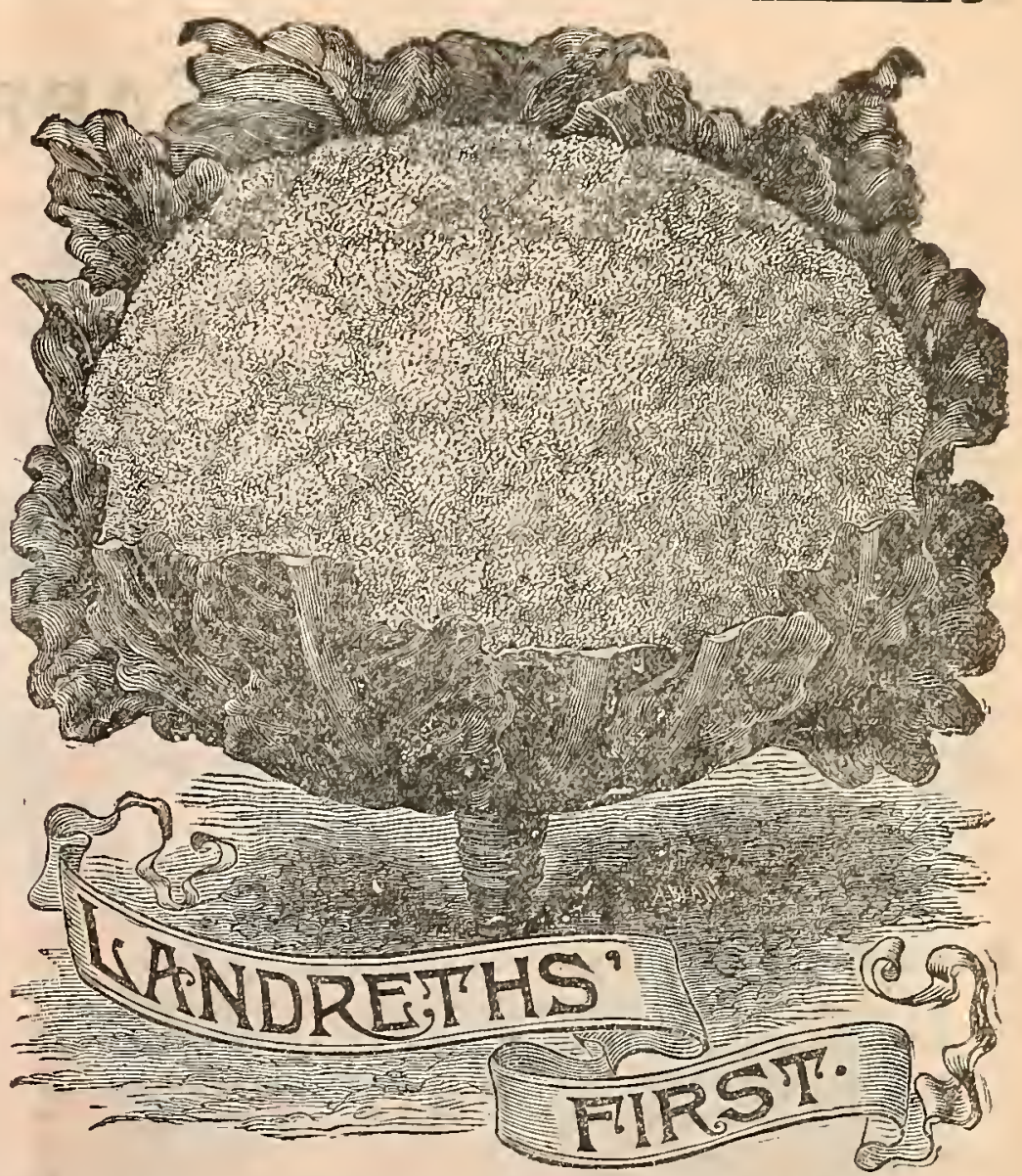

d crumbs and bake in a moderate oven until light bmown and serve hot.

lifower in a bakiug dish, add salt, pepper, nutmeg, cream sauce, bread crumbs

Ealf Early Paris.-A standard variety. Larly, divarf, reliable. Pkt. 10c.; per oz. 70c.

Kalf Eariy French.-A favorite early market variety; large compact heads of fine quality. A trusty variety, Pkt. 10c.; per oz. 70c.

Ordinaty Early Dwarf Erfurt,-An admirable sort, dwarf and early. Not so well selected as the Select Dwarf Erfurt. Ykt. 10c.; per oz. 900

Traperial.-A new and very desirable introduction, medium size, head compact, pure white, and very sliowy wheu well cultivated. Pkt. 20c.; per oz. $\$ 1.50$.

Early A siatic.-One of the early rarieties, aud a reliable sort. PLt. 10c.; per oz. $60 \mathrm{c}$.

Fenormands.-A large late variety,with well-formed heads of superior quality. Pkt. 10c.; per 0z. $75 \mathrm{c}$.

Algiers.-An admirable sort. A farorite with market gardeners. TRX IT. Plit. 10c.; per 0z. 90c.

Large Fate Dutch.-A standard late variety. Heads uniform in size, compact and of good quality. Plzt. 10c.; per 0z. 60c.

\section{ONE MOMENT.}

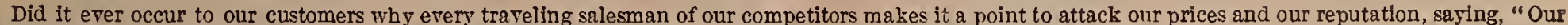
Seeds are as good as Landreths'," and "We will discount Landreths' prices?" Is not this proof that our Seeds are the

\section{American Standard for Purity and Value,}

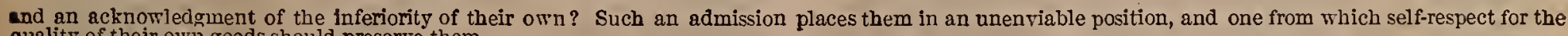
quality of their own goods should preserve them.

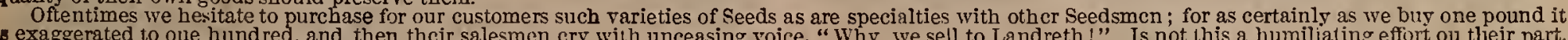
is exaggerated to one hundred, and then thcir salesmen cry

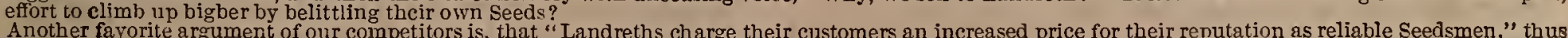

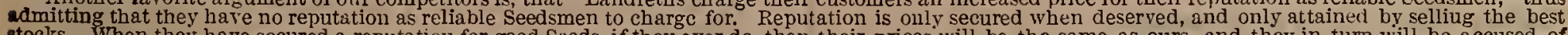

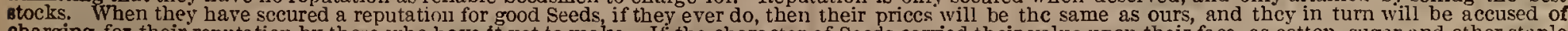

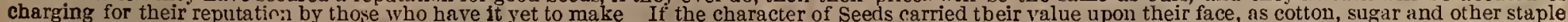

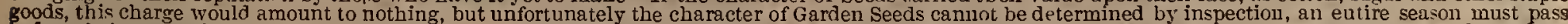

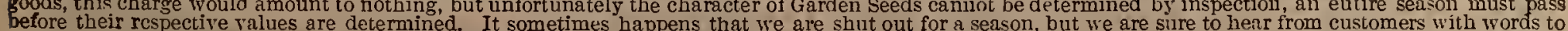

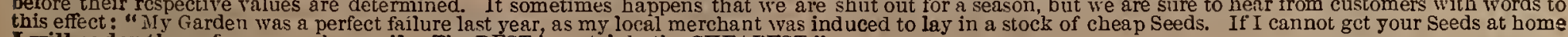
will order them from you by mail. "The BEST is certainly the CHEAPEST."

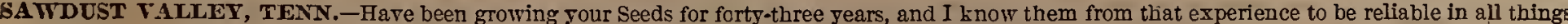
GORDONSVILLE, VA.-This is the forty-fifth year I have planted Landreths' Seeds. 


\section{CARROT.}

Daucus Carota-Carolte-Zanahoria-Möbr $\Re$ übe-Wortel.

THREE OUNCES OF SEED TO 100 YARDS OF ROW. FOUR POUNDS TO ACRE.

For domestic use sow when the Apple is in bloom. Drill in rows of fifteen inches for hand culture, or two and a half feet for field culture, and when two inches ligh thin to four inches apart.

NOTES ON COOKING.-No. 52.-STEWED.-Peel and slice, put in a saucepan with a little brotl, water, salt, pepper and nutmeg. Boil an hour. Thicken with butter kneaded witl flour, mix well and boil. Finish with butter, teaspoonful sugar and chopped parsley. Serve lot.

No. 53. - Is Cream. - Wasli and scrape the outside, cut in small pieces, boil until tender, refresh and boil again. Serve hot with cream sauce.

\section{Extra Early Forcing.}

We recommend this first early variety to market gardeners, as admirably adapted for FoRCING UNDER GLASS, or in the open ground. It is stump rooted, grows about two inches in lengtlı. Pkts. 5c. and 10c.; per oz. 15c.; per $1 / 4$ lb. 35c.; per lb. $\$ 1.25$.

\section{Farly Scarlet Morn, Blunt-rooted.}

Next in maturity after the Forcing. Length four to five inches. Pkts. 5c. and 10c. ; per oz. 10c. ; per 1/4 lb. 30c. ; per lb. $90 \mathrm{c}$.

\section{Early Scarlet Horn, Pointed.}

Sonetimes called "Half Long," being a Long Orange in miniature; quite desirable, growth rapid. Pkts. 5c. and $10 \mathrm{c}$; per oz. $10 \mathrm{c}$; ; per $1 / 4 \mathrm{lb}$. $30 \mathrm{c}$.; per lb. $90 \mathrm{c}$.

\section{Few IXalf Long, without Core.}

Smooth in skin, ricls in color and witlout a core. Pkts. 5c. and 10c.; per oz. 10c.; per $1 / 4$ lb. $30 \mathrm{c}$. ; per lb. $93 \mathrm{c}$

\section{Ox-Heart.}

Diameter of a piut measure, not so long, top shaped. Color, orange red, tender, flavor excellent. Pkts. 5c. and 10c.; per oz. $15 \mathrm{c}$. ; per $1 / 4 \mathrm{lb}$. $45 \mathrm{c}$. ; per lb. $\$ 1.50$.

\section{Chantenay Malforong Scarlet.}

Short, thick, stump rooted. Very productive. Pkts. 5c. and 10c. ; per oz. 10c.; per $1 / 4$ lb. 30c. ; per 1b. $\$ 1.00$.

\section{Nantes.}

(ThIRD EARLY).-This is a thick-rooted, half-long Carrot, unequaled by anything we have ever liad from abroad, slowing marks of the highest breeding, as indicated by its uniformity of shape, color and texture. Pkts. 5c. and 10c.; per oz. 10c. ; per $1 / 4$ lb. 30c. ; per lb. $90 \mathrm{c}$.

\section{Drange Danvers Malf-Long.}

Broad sliouldered, cylindrical, admirable in color, fixed in habit, a wonderful producer, valuable to the stock breeder and market gardener. Pkts. 5c. and 10c.; per oz. 10c. ; per $1 / 4$ lb. $30 \mathrm{c}$. ; per lb. $90 \mathrm{c}$.

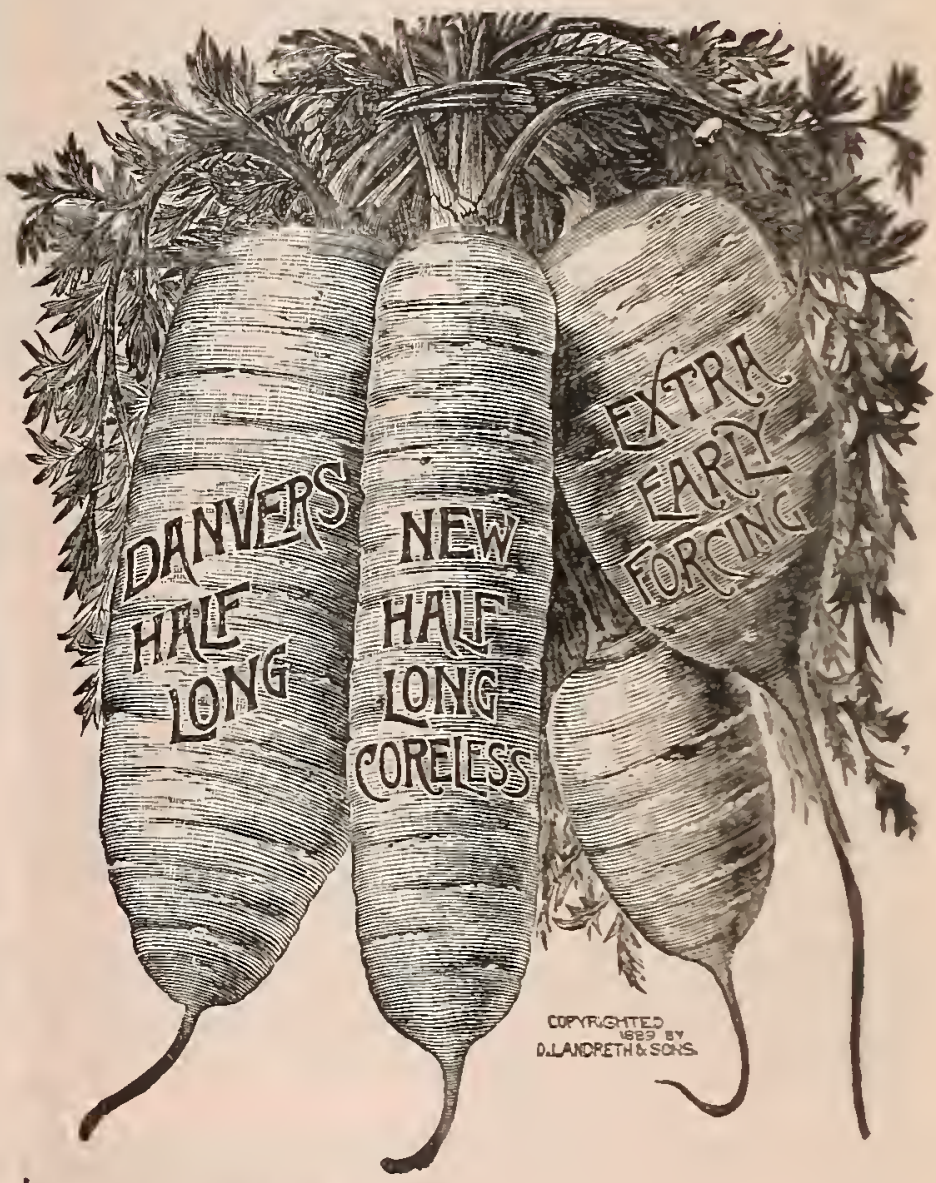

Long Orange.

Pkts. 5c. and 10c. ; per oz. 10c. ; per $1 / 4$ lb. 30c. : per 13.9 .

\section{Long Red Coreless.}

Similar in form to the New Half-Long Coreless, but res fleshed; a very tender and raluable sort for iab!e purposses Pkts. 5c. and 10c.; per 0z. 10c.; per 1: 1b. 3he : fo: th $\$ 1.00$.

\section{Alringham.}

Plits. 5c. and 10c.; per oz. 10c.; per 1; lb, आnc: $90 \mathrm{c}$.

\section{Large White Belgian.}

This variety yields a larger return than others To the milkman it is worth more than tle enst of culture poe moting a liberal secretion of milk of improred gualify ores that from dry food, aud may be fed aliernately mi:l foc: Bagas and Beets, with the best results. PLis. ic. and as. per oz. 10c. ; per $1 / 4$ lb. 20c, ; per lb. ioc.

\section{Large Yellow Belgian.}

Similar to the preceding in erery resmer pxce:tl: Plits. 5c. and 10c.; per 0z. 10c; per is 10 . Ib. $70 \mathrm{c}$. 


\section{CABBAGE.}

We have been engaged in growing Cabbage Seeds for One Hundred and Nine Years, or since 1784 , and should know some= thing about what we write,

Brassica oleracea capilata-Chou Pomme-Col repollo-Slopflobl-Kaal. ONE OUNCE OF SEED TO 100 YARDS OF ROW.

There is not a month in the year nor a day in the month when Cabbage is not being sown in some of the gardening sections of the That must be determined by the practice of each section. In a general way, however, it may be said that Cabbage seed should be sown in February for an early Summer crop, and April or May for an Autumn crop, and in September and October for an early Spring crop. The seed is sown in rows of a foot apart, and after the piants reach a height of three or four inches they are pulled up and transplanted to permanent locations, where they are set iu two feet in the row.

The question is of frequent occurrence: Why cannot private families have head Cabbage as early as market gardeners? Simply because of imperfect culture and insufficient manuring. To produce a successfui crop of Cabbage the soil must naturally or artificially contain potash. phosphate, nitrogen. These are all found in good barnyard manure and in some commercial fertilizers. If these resources are not available, the potash can be had In kainit, the phosphoric acid in bone, or better, in superphosphate; the nitrogen is dried blood, meat or fish.

The market gardener feeds his Cabbage crop wirHour striv' and with the rankest fond; frequently plows in the manure in the Autumn, turns it up in the Spring and thoroughly incorporates it with the soil : plants early, cultivates deeply, not simply tickling the surface with the hand-hoe, but uses the plow and horse-hoe; that cannot always be done in small family gardens, but the spade can be used, and that is the next best thing. Use it freely, dig can be used, and that is the next best thing. Use it freely, dig relied on the hoe alone.

Under good conditions and management about eighty per cent. of the plants in a Cabbage field should, on an averare, produce marketable heads, though sometimes ninety-fice per cent. have been marketed. Market gardeners in Philadelphia, on an average, realize a net profit of about one cent per head. The pickle houses pay about $\$ 8.00$ per ton delivered at their factories.

ETRA EARLY CABBAGES. With much pride we call the attention of Cabbage growers to Landreths' Earhest and Landreths' Early Summer Flathead. They are both super-excellent in every desirable quality. The first, an Extra Early Pointed Head, earlier than any strain of Wakefield. The second an Extra Farly Flat Head, weeks ahead of any other flat or round head. Notwithstanding both are so very remarkably early, they will reach heavy weights

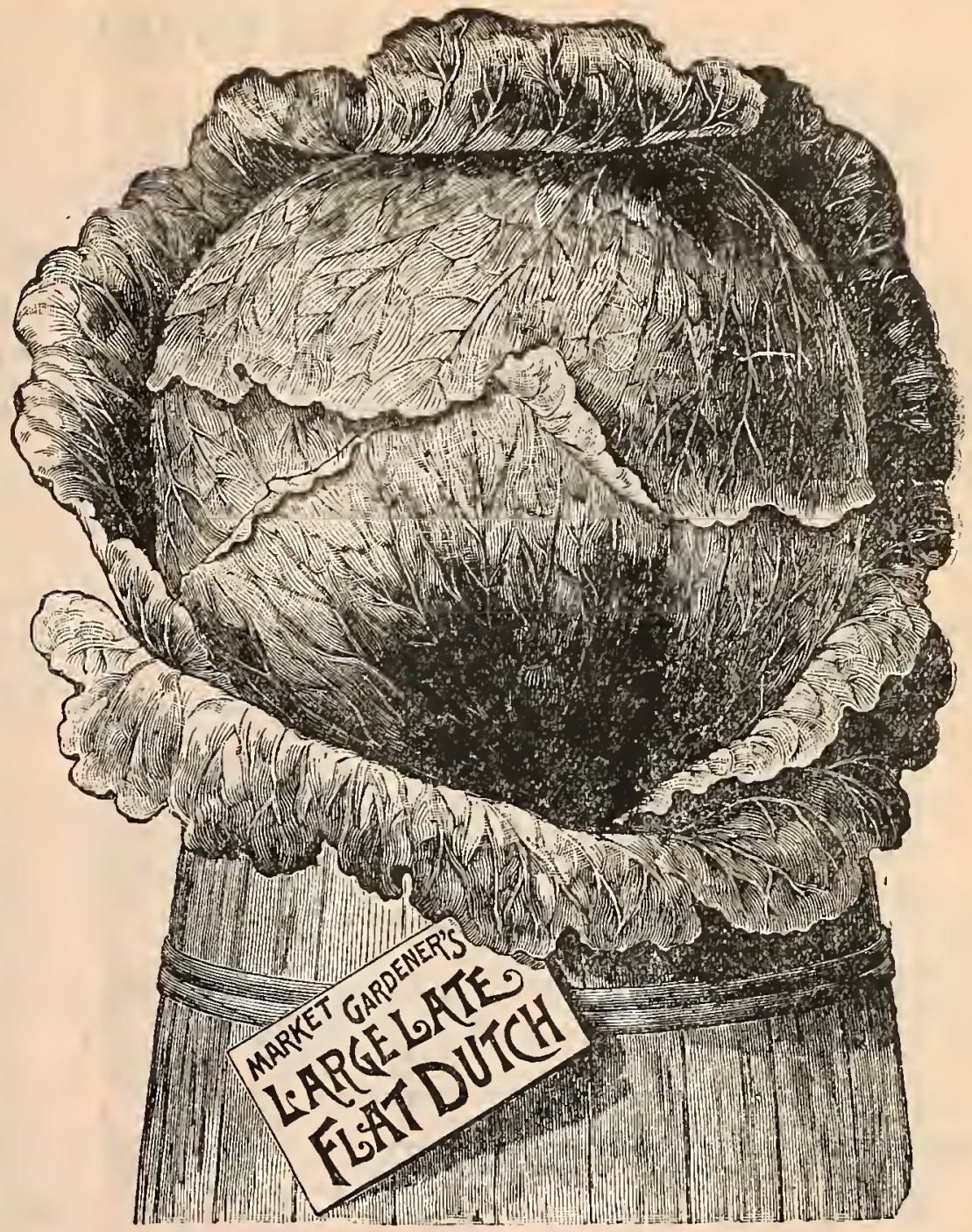

MARKET GARDENERS' LARGE LATE FLAT DUTCH. if given time.

NOTES ON COOKING.-No. 3э.-BoILED.-Carefully prepare and cut in quarters; put ou the fire with plenty of water, and boil, refresh and coo: either with ham corn beef or salt pork. Cook slowly until tender and serve with meat

No. 36. -FRIED. - Use only fresh Cabbage. Remove the outer green leaves, divide in quarters; cut out any hard core; wash carefully; parbotl twenty-five minutes, press the water out and cool. Cut in small pieces, place in saucenan and put in salt and pepper, and fry to a light brown. No. 37.-PICKL

No. 38.-CoLesLAw. - Cut Cabbage very fine, and serve with French dressing, as described under recipe No. 3

No. 39. - SAUER KRAUT. - Use only solid heads shred very finely; take a small water-tight keg and line with Cabbage leaves, sprinkle $1 / 8$ of an inch of salt on the bottom; upon this place three inches of shredded Cabbage, which cover with three tablespoonsful of salt well pressed down, then anothe layer of Cabbage and salt. until keg is full, when hammer down with force. Small portions of herbs, chopped Peppers, and Onions are often added. On top of the upper layer of Cabbage place a circular head of less diameter than the keg, on which fix a heavy weight. When fermentation begins skim of the scum, keeping the cover always in place. To serve Sauer Kraut wash it well in warm water and drain thoroughly. Garnish the edges of the dish with Carrots, Onions, a bouquet of herbs, some chicken or goose grease, and put the Sauer Krallt on top. adding salt pork, sausage. or plece of bacon in

\section{FIRST EARLY VARIETIES.}

Landreths' Earliest Cabbage.-The earliest of all good-sized Cabbages. Some very small sorts may be earlier, but no one can possibly be disappointed with it, as with its EXTREME EARLINESS it unites vIGOR oF GROWTH, WEIGHT OF HEAD and EXCELLENCE OF QUALITY. TEN DAYS EARLIER THAN ANY OTHER CABBAGE, it produces well-formed, conical heads, remarkably large for so early a ripener. Whoever plants it will be amazed at its early maturity, and, if he is a market gardener, will be able to place it in the market ahead of all competitors. We have reports of this variety reaching thirteen pounds in weight, with an average of seven pounds over the field. The color is emerald green, the leaves smooth on pounds over the field. The color is emerald green, the leaves smooth on edge, broad and round at ends. Habit vigorous, short on stem, and proof against sun. The heads are ovoid and hard-few outside leaves and short stem-thus admitting of such close culture as to be planted 1:,000 to the
acre. This Cabbage will do well on soil so light that success with late varieties is not possible. Pkts. 5c. and 10c.; per oz, 35c.; per $1 / 4$ lb. $95 \mathrm{c}$. per $1 \mathrm{~b} . \$ 3.50$.

Gelect Very Early Jersey Wakefield. - The most widely cultivated of the early Cabbages, of great celeurity in the Philadelphia and every other Northern market. It is very early, short stemmed; head. cone shaped, broad at the bot tom with blunt peak : leaves leathery, well folded over the top. A reliable header and most excellent in all good qualities. The strain we offer is unexcelled by any offered under other names, or at a higher price. Pkts. 5c. and 10c.; per oz, 25c.; per $1 / 41 \mathrm{lb}$. 70c. ; per 1b. $\$ 2.50$.
Early York (ENGLISI).-This is an early approved varicty, known in Englaud as Large York. Pkts. $5 \mathrm{c}$. and $10 \mathrm{c}$; ; per $0 \mathrm{z}$. 20c.; per $1 / 4 \mathrm{lb}$. $60 \mathrm{c}$. per lb. $\$ 2.00$.

Landreths' Large York.-The hardiest variety we sell, and generally proof against insects, which, we need not add, is an important quality. Pkts. $5 \mathrm{c}$. and 10c.; per oz. $25 \mathrm{c}$.; per $1 / 4 \mathrm{lb}$. 70c.; per $1 \mathrm{~b}$. $\$ 2.50$.

Reedland Early Drumhead.-To any one wanting an Early Flat-Headed Cabbage of reliability, be he a market gardener, private gar dener or an amateur, we recommend the Reedland Early Drumbead as uniting all the essentials. A variety bred upon our Reedland Farm. It is short stemmed, flat-headed, large and unusually early for a large, broadlocalitics where it has been tried it has becomc a favorite variety, and is

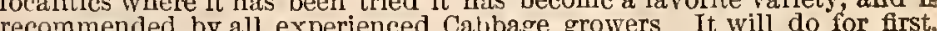
recommended by all experienced Cabbage growers It will do for frst, by us approaches it ill so many desirable qualities, indeed, it suits all seasous, all conditions and all wants; it is the perfection of a Cabbage as respects habit and quality, and one we tie to, as we consider the Reedland to be A No. 1, a gilt-edged sort. Market gardeners at Mlobile write us that, and $10 \mathrm{c}$.; per $02.40 \mathrm{c}$. ; per $1 / 4 \mathrm{lb}$. $\$ 1.10 ;$ per $1 \mathrm{~b}$. $\$ 1.00$.

Louisville Early Drum head.-A short stem, Early Drumhead, possessing every superior quality. Pkts. $5 \mathrm{c}$. and 10c.; per oz. 30c.; per $1 / 4 / 4$
lb. $75 \mathrm{c}$. ; per $1 \mathrm{~b}$. $\$ 2.75$. 


\section{CABBAGE-CONTINUED.}

D10omsdale Bullock.rieart.-This is a FIRST and BEST early ripening with the English Large rork, and a few dars in advance of ripening with the English Large York, and a few days in advance of Landreth' Large York. It is LARGE for a first early, UNIFOR.M, and INVA-
RIABLY PRODUCFS MIARKETABLE HEADS. Where the Winter is severe sow in RIABLY PRODUCES MIARKETABLE HEADS. Where the Winter is severe sow in glass to secure sturdy plants preparatory to setring out. We invite the attention of market gardeners to this variety, feeling assured it is destined to high pepularity. Pkts. $5 \mathrm{c}$. and $10 \mathrm{c}$.; per $0 \mathrm{z}^{4} 40 \mathrm{c}$.; per $1 / 41 \mathrm{~b}$. $\$ 1.10$; per
lb. $\$ .00$.

Landreths' Early Sumuer Flat-Fead.-This is the EARLIEST of the Summer sorts. Heads hard and flat, stem short, few outside leares, uniform in character. Average weight four pounds, sometimes six. Market gardeners praise it highly as just the thing wanted to all the demand for a flat bead. A rariety which may be planted close. UNQUESTIONABLY THE EARIIEST FLAT-HEADFD CABB IGE IN CULTIVATION. Only a day or two behind the earliest Wakefield. No other flat or round head approaches it nearer than a week, as this tollows immediatcly after the Select Early Jersey Wakefield-a large percentage of heads ripen with the Wakcfield. This is a great acquisition, as every markct gardener will immediately recognize. This is not the Early Summer of other catalogues. Ask for Landreths'. Pkts. $5 \mathrm{c}$, and $10 \mathrm{c}$. ; per 0z. 35c.; per $741 \mathrm{~b}$. $45 \mathrm{c}$.; per lb. $\$ 3.50$.

\section{SECOND EARLY VARIETIES.}

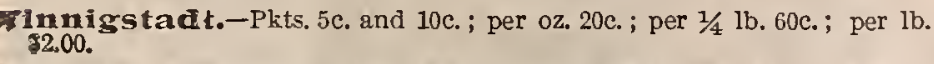

Dloomsdale Farly Market.-This is offered as a SECOND EAP.LY, gucceeding the Bloomsdale Bullock-Heart. It is of EXTRAORDINAPYY SIzE for an early ri pening variety-heads reaching twelve to fifteen pounds under good culture, which it must have to attain perfection. Were we to write a Dage in its praise, WE COULD NOT SAY TOO MUCH. In form it is Write 2 Dage in its praise, WE COULD NOT SAY TOO MUCH. In form it is and cold is comparatively disregarded. It is, however, a ranl feeder, and and cold is comparatively disregarded. It is, however, a ranl feeder, and
Is seen only in perfection on strong, highly manured and, deeply cultirated. It usually heads at Philadelphia the latter end of June, and may be cut successivaly thronghout July. THIS IS NOT OFFERED AS A FIRST

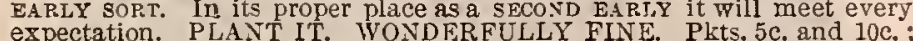
per oz. 30c.; per $1 / 4$ lb. 75 c.; per $1 \mathrm{~b} . \$ 2.75$.

2orge Jersey Wakefield. This is an admirable sort and fully sustains all we have heretofore said in its favor, as a variety suited to the family garden, aidd in some sections it is growing in favor as a market variety. Not so early by two weeks, but twice tne size aud weight of the Early Jersey Wakefield. Heads ox-heart formed and hard. Texture of leaves delicate and tender when cooked. We introducel this variety and 10c.; per 0z. 30c.; per $1 / 41$ b. 75 c. ; per $1 \mathrm{~b}$. $\$ 2.75$.

Few Yorla Farly Summer.-A favorite early sort in the New York market. Heads oval, color bluish green with lighter-colored veins, stem short and stocky. Pkts. $5 \mathrm{c}$. and 10c.; per 02. 30c.; per $1 / 4 \mathrm{lb}$. $75 \mathrm{c}$. ; per lb. $\$ 2.75$.

Bloomsdale Ear1y Drvarf Flat Dutch. -This variety produces thick leaf, very dark blue in color. It has succeeded admirably in the Southern States on account of its ability to resist heat. Its succulent leaves heads after tho early sorts have disappeared. We recommend it highly, not only for the South, but for the North as well. It is one of the very best Summer Cabbages-short in stem and reliable as a producer of fiat compact heads. In the South where Cabbage is usually sown in Autumn, to bo later planted out, to head in early Spring, we know from repeated testicoeding the Large Jersey. Wakefield when similarly treated, and thus forms an untroken succession. To the market gardener of the Northern and Middle States it will be found of especial value sown in cold frames in October and November to plant out in the Spring as a succession to the smaller earlier varieties. Every one should have the Bloomsdale Early Dwarf Flat Dutch. Pkts. 5c. and 10c.; per oz. 30c.; per $1 / 4$ lb. 85c.; per Ib. $\$ 3.00$

Tar1y Flat Dutch (IMPORTED).-An eariy flat head. Plsts. 5c. and 10c.; per oz. $25 \mathrm{c}$; ; per $1 / 41 \mathrm{~b} .65 \mathrm{c}$; ; per lb. $\$ 2.25$.

gioomsdale Early Drumhead.-Iu form, from RoUND to FLAT size large ; always SoLID, few extra leares; rather sHoRT IN STEI and WILI ST.AND WITHOUT BURSTING; such qualities the market gardencr can duly appreciate. For a family Cabbage, to succeed the earler sorts, we cow-

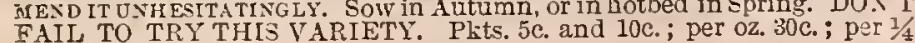
lb. $85 \mathrm{c}$.; per $1 \mathrm{~b} . \$ 3.00$.

Zong Island DKediuni Flat Dutch.- A variety for Autumn an l desirable for both market and family garden. Pkts. 5c. and 10c.; per oz. desirable for both market and fam
$30 \mathrm{c}$; p per $1 / 4 \mathrm{lb}$. $85 \mathrm{c}$; ; per $1 \mathrm{~b}$. $\$ 3.00$.

garly Drumkead (IMPORTED).-Flat head, early, large and of celebrity. Pkts. $5 \mathrm{c}$. and 10c.; per Oz. $25 \mathrm{c}$; ; per $1 / 4 \mathrm{lb}$. $65 \mathrm{c}$.; per $1 \mathrm{~b} . \$ 2.25$.

Randreths' all the rear 'Round.-Ten dars later than the Reedland Early Drumhead. No Cabbage offered as an All-Seasons Cabbage is superior to this, being admirably auapted for Spring, Summer. Autumn or Winter. Without respect to habit or quality, it is the hardiest of Cabbiges grown under the variable climatic conditions of Maine, joung or old, of resisting a greater a mount of frost thau any other, while under the leat and drought of Summer it stands theagring. I"s cinaracter is inclicated by its leares, which are dark blae, thick a.ad Isetisez. The sosd

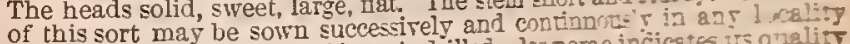
of this sort may be sown successirely and contm incices its praliry
duriug all periods when Cabbage is drilled. Its name incices

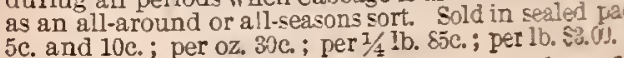

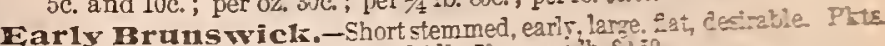

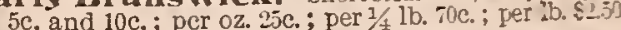

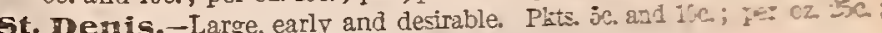
per $1 / 1 \mathrm{lb} .65 \mathrm{c}$; ; per $1 \mathrm{~b} . \$ 225$.

Succession. - Intermediate betreen the Ealr Fa: Durch and he Leie Flat Dutch, slightly later than the second early sors, and man farte than the late sorts. Stem short, sure hearder, heads at and cl Ee. leaved

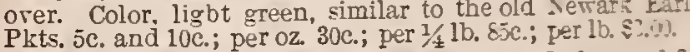

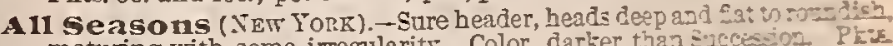

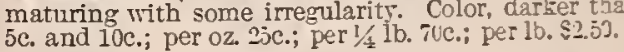

\section{F.ATE VARIETIES.}

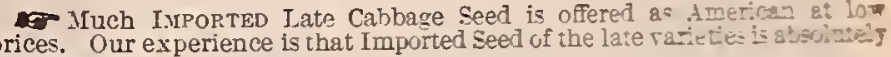
prices,

Market Gardeners' I,arge Late Flat Dutch.-F : a lare. heavy, hard smooth-leaved, late-ripening Cabbage, co sira: and few equal to this. The leares are featbered to the
fluted or twisted on the outer eiges. Color, a clear gneen with 8 s.ar os fluted or twisted on the outer eiges. Color, a clear often become dashed on the margin witb faint to often become dashed on the margin witb faint to
which color sometimes runs into the rein wort of does not affect those forming the head. The hear and sligbtly rounded on the top. though the ror:e fold down alternately. tightly forming a compe habit of the seedling plants is to derelop thick. this quality is affected by the srstem of grow: crowded in the bed or grown among weeds. or a fence or tree, they reach upward for gir and derelopment of long slim stalks, wbich bad for rected by any subsequent culture. The seed is daily orersight, and the strain carefully selected to mot.

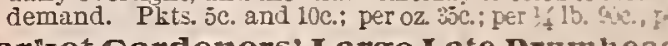
Late large hard\%, certain to head, and being of tear

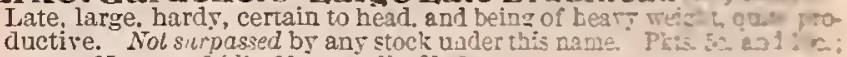

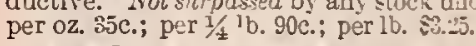

Bloomsdale I,arge I, ate Flat Dutch. variety both for family use and market-gardenes yn

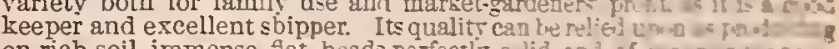
on rich soil immense flat heads perfectly s lid This variety has a short stem, is free from lose lesres \& l we te

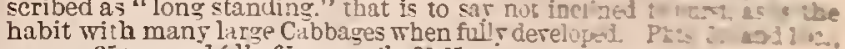
per oz. $25 \mathrm{c}$; per $1 / 41 \mathrm{~b}$. $65 \mathrm{c}$; per $\mathrm{lb} . \$ 205$.

B10omsdale Large Late Drumhead.

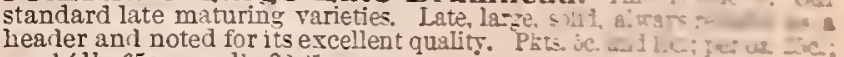
per $1 / 41 \mathrm{~b}$. $65 \mathrm{c}$., per lb. 52.5 .

Landreths' Large Eate Mountain ripening sort, of great constitutional rigot. Hes
to flat. This varietr resists heat and cold betre: as it is of heary weight, will be formd gardener. Color, deep blue. KELIABL per $1 / 4$ lb. Toc.; per $1 \mathrm{~b}$. $\$$ ?

Eergen mammoth. us. Plant hardy and a rant fecter. Pits ino 110 .

Zuncombe. -1 and 10c.; per oz. 25

pes green rarie

Southern States, resisting the attack of Eeas. bus
than others. Pkts. $5 \mathrm{c}$. and $10 \mathrm{c}$; per $\mathrm{oz} 3 \mathrm{w}$; pes

Red Dutch.-Leares red or purple.

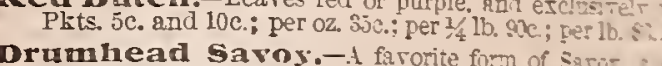
early and desirable in quality. Plts, $3 \mathrm{c}$, an 1 idc.

UIm Saros.-The hest among the foreim nit

Green Curled Savos.-This is ondon Winter Cabbage. After having been fr is not surpassed eren br the Caulitome in is is not to be confounded with LOT-PEICED I

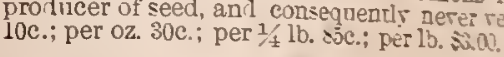

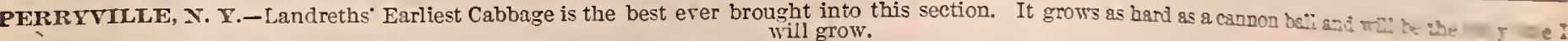

CENTRE POINT, IOWA.-The Department of Agriculture at Washington, D. C., sent me som 


\section{CELERY.}

Apium graveolens-Celeri-Apio-Eellerie-Selleri.

THREE OUNCES OF SEED TO 100 YARDS OF ROW.

How when the Apple is in bloom, on a finely raked surface, and cover scarcely at all, quite early in the Spring, in a moist place or convenient to water, which apply freely in dry weather. When the plants are fon $r$ inches, more or less, in height, transplant a portion into very shallow treuches formed in well-manured land, which plauting repeat at intervals of two or three weeks for a succession, until the necessary quantity is set ont.

NOTES ON COOKING.-No. 68.-STEWED,-Trim off all defective parts and wash thoroughly. Parboil five minutes or until tender and drain tbrough a cloth. Cut stems all the same length and put in a stew-pan, with salt, pepper, butter, and white broth to cover: let simmer for an hur. Drain the Celery through a sieve or cloth, saving the liquor, to which add Espagnole Sauce, see No. 69. Skim the fat so as to form a sauce, press thoroughly through a napkin; place the Celery on a dish and pour over the sauce.

No. 69.-ESPAGNOLE SAUCE.-Take half pound clarified butter, add one pound flour; roast very ligbt brown. Add onions, carrots, a bouquet of herbs, allspice, a knnckle of veal and a ham bone. Let simmer slowly iu saucepan, then moisten with three quarts of stock to a light thin sauce. Let cook for three hours slowly. Skim off the grease; then strain the sauce, and reduce with sberry or white wine, according to taste.

No. 70.-SALAD.-Use the hard roots as well as stems. After washing well cut the stems, both blanched and green, into small pieces. Serve with French dressing, No. 3 , or Mayonaise dressing.

W warf White.-More desirable for the private than the market garden. The dwarf character not inducing ready sale. Hearts white and crisp. Pkts. 5c. and 10c.; per oz. 25c.; per $1 / 4$ lb. $65 \mathrm{c}$; ; per lb. $\$ 2.25$.

Golden Dwarf.-A showy sort of excellent qualities. SolId, of FINE Flavor and a Good KEEPER, aud, as its name indicates, possessing, when blanched, a yellowish or golden tint, stamping it a DISTINCT type and a very desirable addition to the list of rare sorts. Pkts. 5c. and $10 \mathrm{c}$.; per $0 z$. $25 \mathrm{c}$.; per $1 / 4 \mathrm{lb}$. $65 \mathrm{c}$.; per $1 \mathrm{~b} . \$ 2.25$.

Golden Yeart. -Similar to Golden Dwarf. Pkts. 5 c. and 10c. ; per oz. 25c.; per 1/4 1b. 65c.; per $1 b . \$ 2.25$.

Talf Dwarf-A variety of celebrity among the market gardeners in the vicinity of New York, Pbiladelphia and Vashington. It possesses ALL THE QUA LITIEs cssential to mako a perfect Celery-soLIDITY, never being hollow; FLAVOR, a peculiar nutty quality, VIGOR OF GROWTH, dwarf, though producing a weighty bunch. Pkts. 5c. and 10c.; per oz. 25c.; per 1/4 1b. 65c.; per 1b. \$2.25.

Dogton Market.-A short, white rariety, much esteemed in the New England States. Unquestionably one of the best; the only sort sold in Boston markets. Pkts. 5c. and 10c.; per oz. 25c.; per $1 / 41 \mathrm{~b}$. 65c. ; per lb. $\$ 2.25$.

- arls Colden Yellow.-A large solid golden variety, superior to White Plume very showy and rich Very easily blanched consequently early. Ṕt. 10c.; per oz. 40c.; per $1 / 4$ lb. $\$ 1.00$; per $1 \mathrm{~b}$. $\$ 3.75$.

White Plume.-Self-blanching to a great extent. Consequently among the earliest ready for table. Desirable as an early sort. Pkts. $5 \mathrm{c}$. and 10c.; per 0z. 35c.; per $1 / 41 \mathrm{~b} .95 \mathrm{c}$. ; per $1 \mathrm{~b} . \$ 3.50$.

sed or Pink.-A rariety fancied by some by reason of its distinctive color and HARDINEss. Quality good, desirable in the private garden as one of the most reliable sorts, Pkts. $5 \mathrm{c}$. and $10 \mathrm{c}$.; per $0 z .25 \mathrm{c}$. ; per $1 / 4 \mathrm{lb}$. 65 c. ; per lb. $\$ 2.25$.

1,arge Vhite.-The most imposing of all rarieties though not as deucate as dwarfer sorts. Pkts. 5 c. and $10 \mathrm{c}$; ; per $0 z .25 \mathrm{c}$; ; per $1 / 4 \mathrm{lb} .65 \mathrm{c}$; ; par
lb. $\$ 2.25$.

Clant Pas cal.-A mammoth silver white stalked variety of French origin, rapidly growing in favor because of its weighty productiveness and consequent profitableness. Pkts. 5c. and 10c.; per oz. $25 \mathrm{c}$.; per $1 / 41 \mathrm{~b}$. 700 ;

Sandringham.-A celebrated English rariety. Pkts. 5c. and 10c. ; por oz. $25 \mathrm{c}$. ; per $1 / 4$ lb. $65 \mathrm{c}$. ; per lb. $\$ 2.25$.

Celeriac, or Turil ip-rooted (IMPORTED SEED).-A variety formine a large solid root of edible character. Pkts. $5 c$. and 10c.; per oz. 20c.; par $1 / 4 \mathrm{lb} .60 \mathrm{c}$; p per lb. $\$ 2.00$.

Flavoring for Soups.-This seed is not for sowing, but for flavoring purposes only. Pkts. $5 \mathrm{c}$. and $10 \mathrm{c}$; ; per oz. $10 \mathrm{c}$.; per $1 \mathrm{~b}$. $30 \mathrm{c}$.

HartweIl Perfection. - A desirable form of white sotid habit. Plts. 5c. and 10c. ; per oz. 25 c. ; pcr $1 / 4$ lb. 65 c. ; per $1 \mathrm{~b} . \$ 2.25$.

\section{COLLARDS.}

Brassica Oleracea Acephalo-Choux verts-\$inter fohl-Coles Sin Cogollo.

ONE OUNCE OF SEED TO 100 YARDS OF ROW.

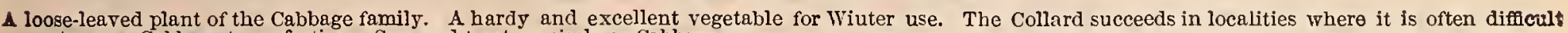
to grow Cabbage to perfection. Sow and treat precisely as Cabbage.

PInk Feart.-This has never been offered by any other Seedsmen The lower leaves are green with bone-white veins or ribs, the interior leaves are ivory-white, like finest bleached Cclery, the leaves about the hear are PINK and purple. It is very unique and worthy of culture in the best gardens by reason of its beauty as an ornamentul plant and by reason of its tender and delicious quality as a table vegetable, boiling as it does marrow-like as Cauliflower. Pkts. $5 \mathrm{c}$. alla $10 \mathrm{c}$.; per oz. $30 \mathrm{c}$; p per $1 / 1 \mathrm{lb}$. 85c.; per 1 b. $\$ 3.00$.

White I.eaved.- Very rare and very choice, the plant producing centre leaves generally nerfictly white, though sometimes dashed with pink. In quality it is much more delicate tban the ordinary Soutbern Collard, and is highly recommended both as a curiosity and a garden regetable of the first quality. Pkts. 5c. and 10c.; per $0 z$. 30c.; per $1 / 41 \mathrm{~b}$. $75 \mathrm{c}$.; per

Landretis' Mr arrow.-A plant of the Cabbage family, producing a strong growth of broad leaves, borne upon white marrow-like stalks or stems, which, with tbe broad waxy midribs stripped of leaf matter, afford a dish much resembling Caulifower. This plant can bo grown in any section and by any novice. Stems cooked like Canlifiower. We recommend it to all as superior to any form of Collard. Plits. 5c. and 10c.; per oz. 20c.; per $1 / 4$ lb. 60c.; per 1b. \$2.00.

Creole, or Southern.-Cabbage Greens. Its robust and vigorous character fits it to resist conditions unfavorable to tbe perfection of more highly dereloped types of the Cabbage family, and it is, therefore, st some sersons in the Southern States, the only available form of Cabbage. Pkts. 5c. and 10c.; per 0z. 15 c.; per $1 / 41 \mathrm{lb}$. 35c.; per $1 \mathrm{~b} . \$ 1.25$.

\section{CORN SALAD.}

Valeriancella olitoria-Mache Commune-2rderjalat ober Stewialat-Canonigos-Koornsalad.

EIGHT OUNCES OF SEED TO 100 YARDS OF ROW.

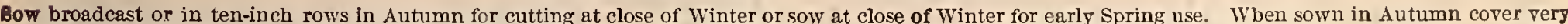
lightly with the lightest hay-the merest protection more will be injurious.

Broad Ieaved (LARGk, SEEDED).-Used as a small salad throughout the Winter and Spring. Sow thickly in drills, cover slightly first of Autumn, and sprinkle with straw on the approach of severe weather, or sow in

cold frame, covered in Winter as may be convenient-thus it is accessible even when deep snow prevails. Pkts. 5c. and 10c.; per oz. 10c.; per $1 / 4$ 1b. $25 \mathrm{c}$.; per $1 \mathrm{~b}$. $75 \mathrm{c}$.

Postage extra. On Peas and Beans, 16 cents per quart, and Corn, 15 cents per quart; other small Seeds, 8 cents per pound, Quarter pound and under, and 5 and 10 cent Flat Papers, Free of Postage. 


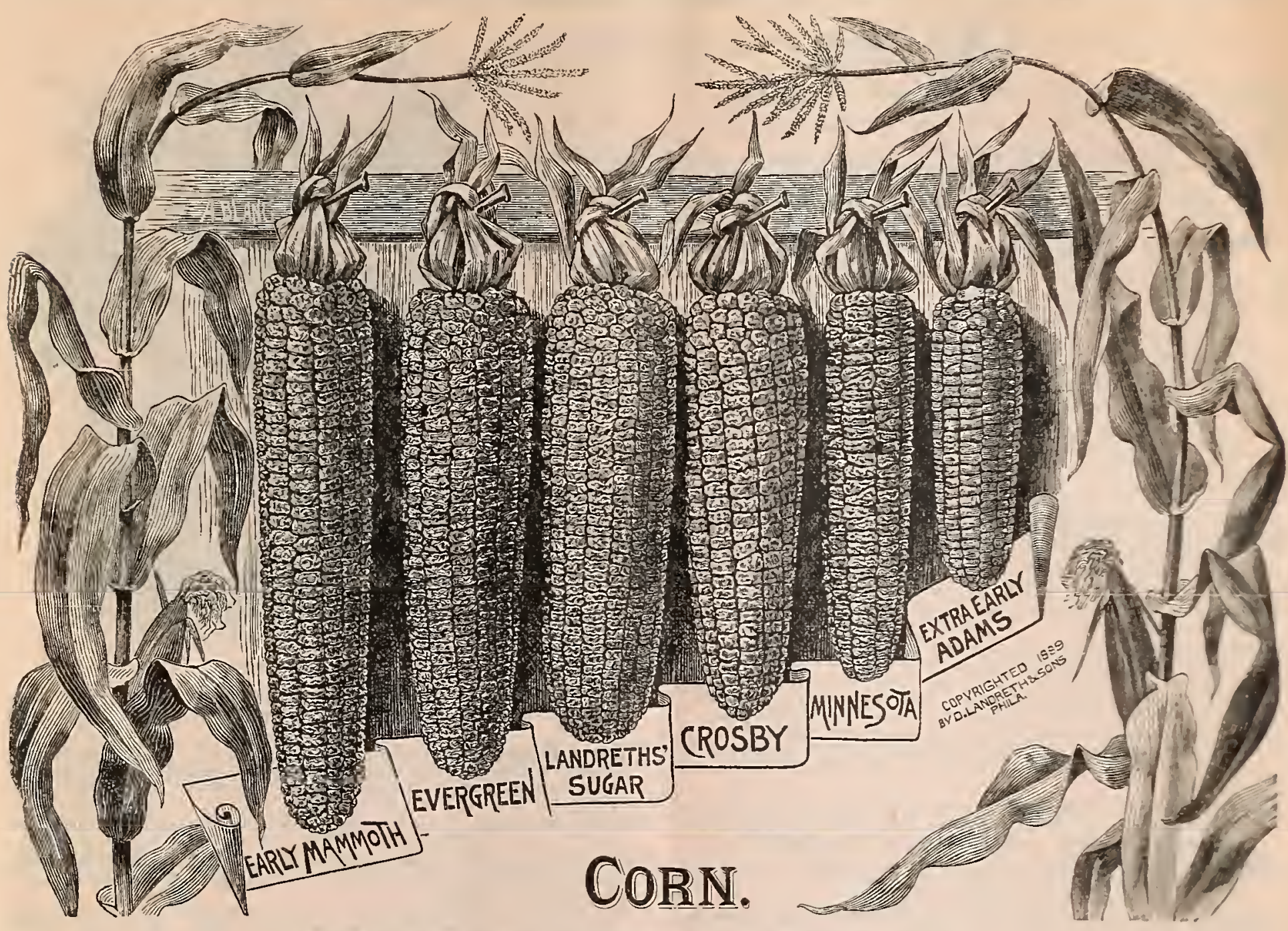

Zea-Mais-Haiz Para el uso de la mesa-Welf

ONE QUART OF SEED TO 100 YARDS OF ROW. EIGHT QUARTS TO THE ACRE.

Wais is a native of North and South America, having been found in cultivation by the first European royagers. Modern researches in Peru a.j $\mathrm{Yexico}$ Lare given evidence that its culture extends far beyond any listoric period.

There is no foundation whaterer for the statement that Indian Corn has been found in the wrappings of Egrptian mummies; sach tals teine fabrications. Seeds of Wheat, Sorghum and Millet hare been discovered, but it is douhtful if any sueth seed ever vegetated.

Indian Corn may be divided into six classes, viz.: Pop-Zea Everta; Flint-Zea Indurata; Dent-Zea Indenata; Sof-Zar Anyisna. Sweei-Zera Saccharatum; Pod or Husk-Zea Vaginata; and each of these are subdivided according to shape of the ear, number of roirs upon each eas, eis
Table Corn cannot-be planted successfully at an earlier date than the ordinary field varieties, indeed it is more likely to decar conditions than the hardier field varieties. As a rule, Sugar Corn is not as vital as the field sorts, and therefore it is wise to dlane under unferas "e son? of grains iu the hill as compared with Field Corn.

When the cherry is in bloom, hills for the short varieties of three and fonr feel in height mav be made three by three feet apart; sor the is re-metia.e varieties three by four feet; and for the tall varieties, four hy four feet apart. In all cases allowing three stalks to stand to the hill

Repetitions of Corn planting should be made erery two weeks, and for the quick-ripening varieties the planting mar be continued unet? days of frost. Seed should be provided at the rate of ten quarts to the acre. We always provide that much, though often or!s quarts. The plants thinned out to three inches apart.

Of the medium and large varieties of Sugar Corn serenty-five to eighty kushels, or $80 n$ to $90 n 0$ roasting ears. can he had to the ars

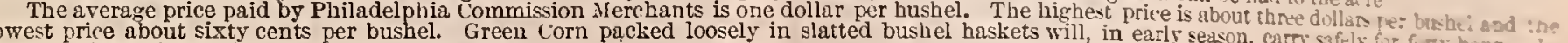
lowest price about sixty cents per bushel. Green corn packed loosely in slatted bushel haskets will, in early season, carry safely fo: ff:y buca. CAUTION. - Seed Corn in bulk should be taken out of the bags as soon as received and spread out in a dry place.

FOTES ON COOKKNG.-No. 81.-BoIIED - Wash and boil in plenty of water with a small quantily of milk: cook for twentr minutei

No. 85.- FrITTERs. - G rate Corn raw or cooked. For dressing take one pint of milk, four eggs. two teaspoonsful of baking porder, hilf Ealt, pepper, sugar; heat into light batter. Fry on both sides in pan with liot lard, one tahlespoonful of hatter to each fritter.

a Green Corn should never bc allowed to heat, hut soon as receired spread out upou a cool foor.

\section{FIELD CORN.}

ONE PINT OF SEED TO 100 YARDS OF ROW. EIGHT QUARTS TO THE ACRE.

Landreths, Fxtra Farly Vellow Summer gint.-This rum producing a slim ear of zellow flint grain, is a sort of exceeding productiveness on elevated lands in th. Middle States and in the firr Northern States, where it frequently produces sixty to eighty hushels per acre. Pkts. 5e. and 10c.; per qt. 15c.; per $1 / 4$ bush. 85 c.; per reaming (EARLY) - An earl selecto

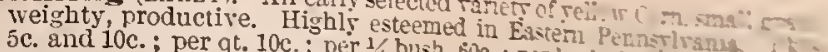
Golden Dent (sHowr). - Named from the bright colvo of the is

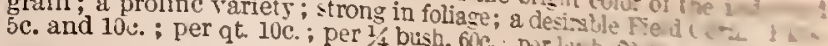




\section{FIELD CORN-CONTINUED.}

Pennsylvania Loing Early Yellow Flint,-Long, narrow ears; gram reddish yællow and flinty; a productive Field Corn, quite

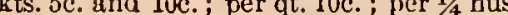
Stalks sHORT, ranging from six to eight feet. Ears set low, large aud well filled, fifty-six to sixty shelling a bushel of corll. So productive as to be
relied upon for a return of ten bushels per acre over any other corn in relied upon for a return of ten bushels per acre over any other Corn in
Pennsylvania. Pkts. 5c. and 10c.; per qt. 10c ; per $1 / 4$ bush. 60c.; per bush. $\$ 2.00$

Landreths' Laroe White F1int.-Long slim ears, covered with pure white flinty grains. The best sort for hominy. This variety is superior to that usually sold. Pkts. 5c. and 10c.; per qt. 15c. ; per $1 / 4$ bush. 70c.; per bush. \$2.50.

Tuscarora.- "Flour Corn," so called by reason of the snow-white ehazacter of interior of grain; grain full, soft. Pkts. $5 \mathrm{c}$. and 10c. ; per qt. $15 \mathrm{c}$. per $1 / 4$ bush. $85 \mathrm{c}$; ; per hush. $\$ 300$

Southern White Gourd Seed.-A very sluwy variety; large grain and snowy white. Admirable for meal. Only offered for Southern eulture. Pkts. $5 \mathrm{c}$. and 10c.; per qt. $15 \mathrm{c}$.; per $1 / 4$ bush. $85 \mathrm{c}$. ; per bush. $\$ 3.00$.

O1d Cabin Fome (REMARKABLE).-A thickeared Southern type of white Corn with enormously deep and broad grain and extraordinary slim cob. Remarkably fine for meal. Pkts. 5 c. and 10c.; per qt. 15c.; per $1 / 4$ bush. $85 \mathrm{c}$; per bush. $\$ 3.0$ J.

\section{SWEET GARDEN CORN.}

\section{NOT TRUE SUGAR.}

Eectra Early Adams (SIXTY DAYS). -The earliest white Corn, ready for table sixty days after germination. Height of stalk three to four feet ears set within six inches of the ground. Not a Sugar Corn, but a decided acquisition so very early in the season. Requires good culture and LAND acquiGH FERTIrY ers. Pkts. 5 c. and 10c. ; per qt. 20c.; per $1 / 4$ bush. $95 \mathrm{c}$. ; per bush. $\$ 3.50$.

Adams Early, - A white Corn, next among white Corns in order of maturity after the Extra Early Adams. Pkts. 5c. and 10c.; per qt. 15c. per $1 / 4$ bush. $85 \mathrm{c}$. ; per bush. $\$ 3.00$.

Farly Land reth Market.-Not a true Sugar Corn, but a hybrid or mixture between a Sugar Corn and the Adams Early, and cultivated on large areas and almost exclusively by the market gardeners of Burlington county, New Jersey, experience proving the sort to be more reliahle than any other variety. The ear when in proper coudition for the table resemhles a good variety of Sugar Corn, and has the peculiarit of hearing a small leaf on the ear, simillar to those of the stalk, which appendage sets it off to advantage. The edible grain is white and swest. The dry grain is a mixture of Sugar, Adams Early is white and sveet. The dry grain is a mixture of Sugar, Adams Early and White Flint, and presents all the a ppearance of a very much mixed sort, but it is far better
than it looks. This variety will mature ears for market in about eirht than it looks. This variety will mature ears for market in about eighty
days from germination. The stalk is quite leafy and grows to a height of six feet. A very profitable sort as a money-maker. Pkts. 5c. and 100.; per qt. $20 \mathrm{c}$.; per $1 / 4$ bush. $95 \mathrm{c}$.; per bush. $\$ 3.50$.

\section{SUGAR CORN.}

Dolly Dutton Sugar.-Exceedingly early and $d$ warf, valnable before others come in. Pkts. 5 c. and 10c.; per qt. 20c.; per $1 / 4$ bush. $95 \mathrm{c}$.; per bush. $\$ 3.50$

Corey.-A valuable sort, earlier than the Narragausett aud more robust. Graiu half amber. Pkts. 5c. and 10c.; per qt. $20 \mathrm{c}$. ; per $1 / 4$ bush. $95 \mathrm{c}$. ; per bush. $\$ 3.50$

Extra Early Narragansett Gugar.-Among the Extra Early faring for table in 60 days from germination. height of stalk four and a half feet. Grain rerl when dry. Pkts. 5c. and 10c. ; per qt. 20c.; per $1 / 4$ bush. $95 \mathrm{c}$. ; per bush. $\$ 3.50$.

Extra Early Minnesota Sugar.-Among the Extra Early Sugar Corns, coming into condition two or three days subsequent to the Narmgansett. Ears well made out. Desirable in the fanily garden and profitable to the shipper. Pkts. $5 \mathrm{c}$. and $10 \mathrm{c}$; per qt. 20c.; per $1 / 4$ bush. $95 \mathrm{c}$. per bush. $\$ 3.50$.

Farly Marblehead.-Similar to the Narragansett, but not such red grain. Pkts. 5c. and 10c.; per qt. 20c. ; per $1 / 4$ bush. 95c. ; per bush. $\$ 3.50$.

Extra Early Crosby Sugar.-This variety will produce edible ears in seventy days from germination. It is stronger than any of the prece.
ing. Pkts. $5 \mathrm{c}$. and 10c.; per qt. $20 \mathrm{c}$; ; per $1 / 4$ bush. $95 \mathrm{c}$; ; per bush. $\$ 3.50$.

Darling's Sugar.-An old standard varicty of high merit. Pkts. 5c. and 10c.; per qt, 20c. ; per $1 / 4$ bush. $95 \mathrm{c}$.; per bush. $\$ 3.50$.

Farly Concord Sugar. - An excellent early variety, succeeding the Crosby. Height of stalk about five feet. Pkts. 5c. and 10c.; per qt. 20c. per $1 / 4$ bush. $95 \mathrm{c}$. ; per bush. $\$ 3.50$.

Rickox Sugar. -An excellent sort succeeding the Concord. Pkts. 5c. and $10 \mathrm{c}$.; per qt. $20 \mathrm{c}$; ; per $1 / 4$ bush. $95 \mathrm{c}$. ; per bush. $\$ 3.50$.

Asylum Sugar.-More vigorous than Crosby. Stalk six feet, ears long -quite desirable. Pkts. 5c. and 10c. ; per qt. 20c.; per 1/4 bush. 95c. ; per bush. $\$ 3.50$.

T,andret hs' Sugar.-A remarkabl y satisfactory and productive variety, two ears on every stalk, often three, sometimes four. Stalk two feet shorter than the Evergreen, and very close jointed. The ears set low, large and well filled. The grain is narrow and very long, or deep, somewhat similar in shape to Evergreen, but smaller. The ear remains long in milky condition for the table, the edihle grain being pure white and exceeding sugary. The Landreth Sugar Corn is a very showy variety, exceeding sugary. The Landreth sugar Corn is a very showy variety, both in stalk and ear, and will mature for marketing in eighty-two days, eight days earlier than the Evergreen. The Landreths' Sugar Corn will afford market gardeners more baskcts of marketalble ears to the acre than any other variety of Sugar Corn in cultivation, and is valuable to the eanner as having almost as long a grain and ripening earlier than the Evergreen, while pnssessing all the merits of the Evergreen under processing. We reeommend it, without qualification, as being undoubtedly 10e. ; per qt. $20 \mathrm{c}$. ; per $1 / 4$ bush. $95 \mathrm{c}$. ; per bush. $\$ 3.50$.

squantum Sugar.-A rariety of celebrity in the Nerw York markew Pkts. 5c. and 10c.; per qt. 20c. ; per $1 / 4$ bush. $\$ 1.00$; per bush. $\$ 3.75$.
Amber Cream Sugar.-Very rich in flavor firains amher whes hard. Pkts. 5c. and 10c ; per qt. 20c.; per $1 / 4$ hush. $95 \mathrm{c}$.; per hush. $\$ 3.59$.

Golden Sugar.-A medium stalk, producing an arerage ear of des? yellow grain, very sugary. Pkts. $5 \mathrm{c}$. and $10 \mathrm{c}$.; per qt. $20 \mathrm{c}$.; per $1 / 2$ busk.
y5c.; per hush. $\$ 3.50$.

Large Coh Sugar (PERRY's). - An early variety, producing a large eur set with large grains. Pkts. $5 \mathrm{c}$. and 10c.; per qt. $20 \mathrm{c}$.; per 1/4 buslı. $95 \mathrm{c}$. per bush. $\$ 3.50$.

Triumph Sugar. -A variety following the Asylum in maturity. Sweet productive and of good appearalice. Pkts. 5c. and 10c.; per qt. 20c., pes $1 / 4$ bush. $95 \mathrm{c}$. ; per bush. $\$ 3.50$.

Early Mammoth Sugar (RARE). - An early variety bearing exceet. ingly long ears. Stulk short and slender. Early in maturity for so large an ear, showy and highly recommended. TRY IT. Pkts. 5c. and 10c. per qt. 20 c. ; per $1 / 4$ bush. $95 \mathrm{c}$. ; per bush. $\$ 3.50$.

Eight Rowed Sugar.-Maturing for table about seventy-five dayl from germination. Fars long and named from number of rows. Pkte. 5c. and 10c.; per qt. $20 \mathrm{c}$. ; per $1 / 4$ bush. $95 \mathrm{c}$. ; per bush. $\$ 3.50$.

Red Cob Sugar.-A standard variety in many markets. Pkts. 5c. and $10 \mathrm{c}$; ; per qt. $20 \mathrm{c}$, ; per $1 / 4$ bush. $95 \mathrm{c}$; ; per bush. $\$ 3.50$.

Black Niexican Sugar.-The Black Sugar Corn is especially rich in saccharine or sugary qualities. The grain, though black when dry, is simply of a smoky liue when ju eáihle couditiou. Pkts. $5 \mathrm{c}$. end 10c.; per qt. 20c.; per $1 / 4$ bush. $95 \mathrm{c}$.; per bush. $\$ 3.50$.

Evergreen Sugar (STOWELL'S). A favorite rasiety among the late Sugar Corlis. Mrutures for table about eigity days from germination. Pkts. $5 \mathrm{c}$. and $10 \mathrm{c}$.; per qt. $20 \mathrm{c}$; ; per $1 / 4$ bush. $95 \mathrm{c}$.; per bush. $\$ 3.50$.

Late Mammoth Sngar.-The late Mrammoth is the strnngest grow. ing of all Surar Corns It requires about eighty-five days to reach maturity for tahle. The ears a re very large and showy. Pkts. 5c. and 10c. ; per qt. $20 \mathrm{c}$.; per $1 / 1$ bush. $95 \mathrm{c}$. ; per hush. $\$ 3.50$. Egyptian Sugar.-Sweet and large in ear, vigorous in stalk, hahit
late. Plts. 5c. and 10c.; per qt. 200 . ; per $1 / 4$ kush. $95 \mathrm{c}$; ; per bush. $\$ 3.50$.

Ensilage Sugar Cor11.-By broadenst sowing, or drilling in close rows, a luxuriant growth of sugary forage may be obtained from this
Corn. Cut when just showing the flower spike, as in that condition it is Corn. Cut when just showing the flower spike, as in that condi
most nutritious. Per qt. $15 \mathrm{c}$; ; per $1 / 4$ bush. $70 \mathrm{c}$; per bush. $\$ 2.50$.

Ruby.-Red all over-stalk, leaves, husk, cob and grain, when dry. A novelty possessing admirable flavor aud unexcelled in sweetuess. Worthy of cultivation by c very one. Pkts, $5 \mathrm{c}$. aud $10 \mathrm{c}$; per at. $20 \mathrm{c}$; per $1 / 4$ bush. $95 \mathrm{c}$; ; per bush. $\$ 3.50$.

Country Gentrenaun. A short-stalked productive sort, frequently producing threc ears to the plant. Ear large for so small a stalk; grain. I’kts. 5 c. aud 10c. ; per qt. $20 \mathrm{c}$; ; per $1 / 4$ bush. $95 \mathrm{c}$. ; per bush. $\$ 3.50$.

FADKINVILLE, N. C.-I have been an aunual customer of Landreths' Seeds for fifteen ycars, and my parents forty years earlier. My neighbors als depend on me to get your seeds for them. 


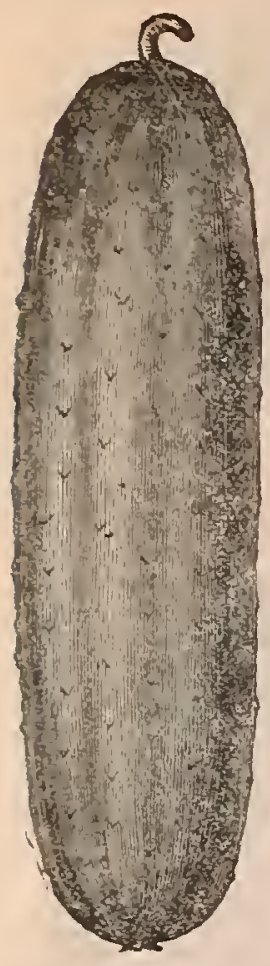

\section{CUCUMBER.}

Cucumis sativus-Concombre-Burle-Agurker-Eomkommer.

FOUR OUNCES OF SEED TO 100 YARD'S OF ROW. THREE QJARTS TO THE ACRE.

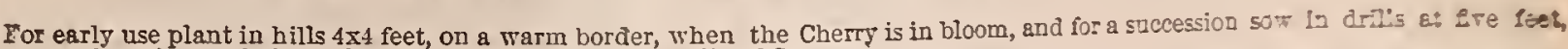
When the Apple is in bloom. For pickles plaut middle of Summer

In Floridd and other Southern States, a fair arertae production per acre of Slicing Cucumbers is two hrad:ed crate $8 \times 14 \times 20$ inches Some growers claim ayerage crops of 400 and 500 -eren 800 crates hare teen recuded, but these large yield are unls occasionally heard of.

Fresh Southern Cucumhers appear in Philadelphia the last of Norémber, and command sI to :2 per dozen. Iowards Ch-ismas the price rises to $\$ 2.50$ per dozen, after which ihe price declines to $\$ 4$ or $\$ 5$ per box of eightr. May the price goes down to $s 1$ per dozen, after which shipments are unprofitable. As a'the Orieans bring better prices thau those from. Florida, being vetter sorted and better packed.

A good crop of Cucumbers, when gathered of pickling size, produces from 100 to 15 bushels to the ene. A tus ei conialas

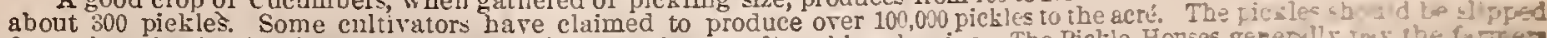

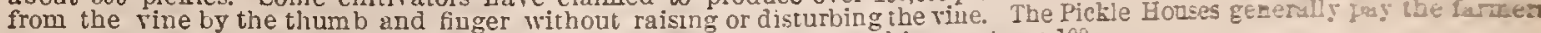
forty to fifty cents per bushel, they in turu sell them at from tweuty to thirity cents per 100.

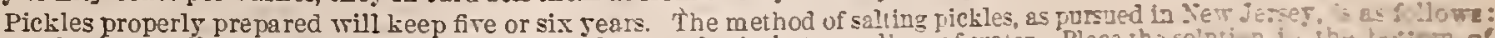

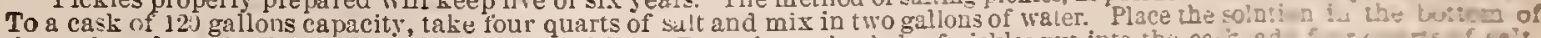

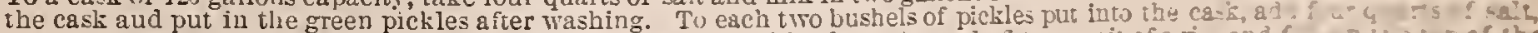

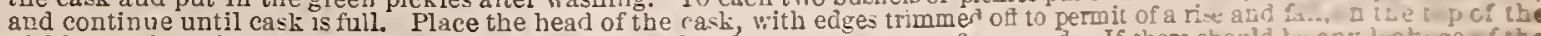
pickles, and on the top of the head or lid place a weight of twentr or twentr-five pound. If there should be acy l-atuse o tue

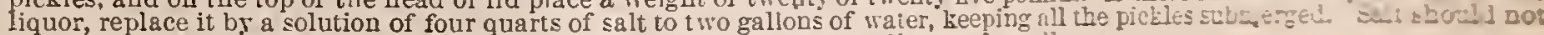
he stinted. Pickle Packers make three sizes before pickliug-large, medium and smait.

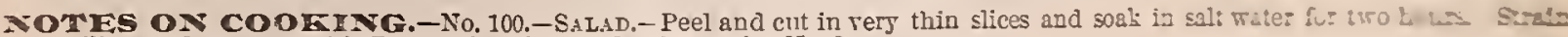
till rery dry, serve with French dressing made after recipe 10.3.

No. 101.-Slicrd. Pickled.-Peel and slice fresh Cucumbers and put in a pan anõ let siand with fleavy of ca?: to draw tho water. Press dry and put them in a jar, pour over cold boiled vinegar. Add salt, pepper and a fer elict uf on:0-

\section{FIELD VARIETIES.}

Candreths' Furst.-The earliest long field Cucumber in cultivation dark green and desirable. Very rare. Vers pnor seeder, therefore high priced. Plts. 5c. and 10c.; per oz. 20c.; per $1 / 4$ lb. 50c. ; per lb. $\$ 1.75$.

I, andretis, Cboice (EXTRA EARIY).-The choicest sort we hare ever offered, green, long slim, srmmetrical, unexampled in heauty of form, very productive, fine for pickling. Pkt. 20c. ; per oz. 60c.

Short Prolific Pickle. - A variety of the "Frame" type, but for pickling in fifty day's from plant ing. An abundant bearer, highly commended for pickles, for which
it is used by many of the most it is used by mans of the most Vines rery short, admitting of planting in rows as close as two and 8 half feet. In seediug this variety we do not drop the seed in hills but Grill in continuous rows as ve would Beans, about one seed to the inch, and when the plants are irell estaband when the plants are trell estab-
lished, cut them out to about three lished, cut them out to about three
inches apart. We hare a very large demand for this variety. Plits. 5c. and 10c. per oz. 10c.; per $1 / 4 \mathrm{lb}$. $25 \mathrm{c}$; ; per ib. $80 \mathrm{c}$.

Improved Early White spine.-The leading sort grown by truckers for slipment to market. by truckers for shipment to market. Used almost entirely for slicing. The vine in habit is sery rigorous
and vers prolific. The fruit is of good size, in quality solid, and possesses the habit of retaining its IMPROVED EARLY WHITE SPINE. green color for a long period, that is to sar it dees nat tars reilow

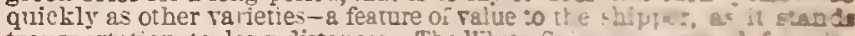

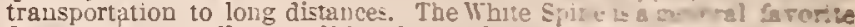

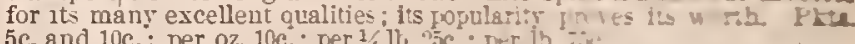

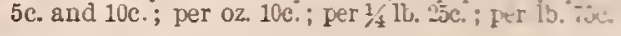

Early Frame.-Pkts. sc. and 10c.; per $02: 0 c$; per ${ }^{3}, 1 \mathrm{~b}$. asc. : fre: $1 \mathrm{~b}$.

Ear1s Cluster.-Plts. 5c. and 10c.; per oz. 10c.; pe: 1; 1b. 25e. : per ib. 750.

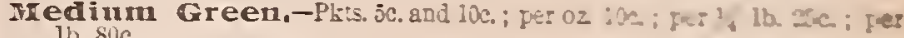

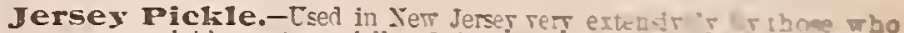

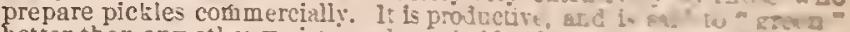

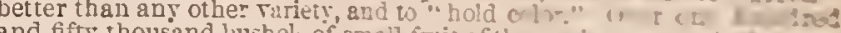

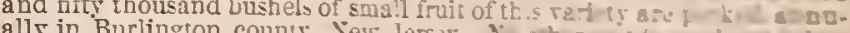

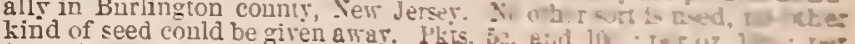

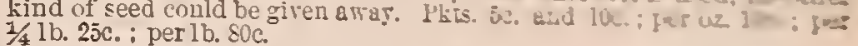

Boston Pickling, or Boston srarket. $-[-d$,

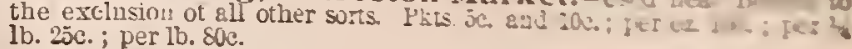

Turkey I.ong Green.-.Tot so abandant a han as tha ... cent-a

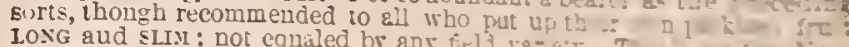

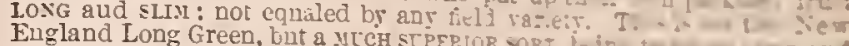

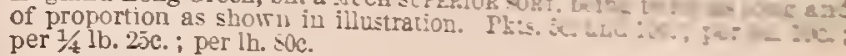

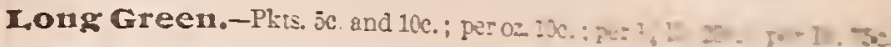

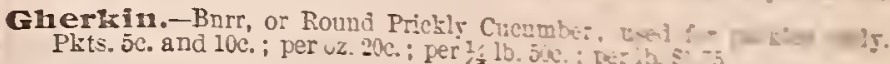

\section{HOTHOUSE VARIETIES.}

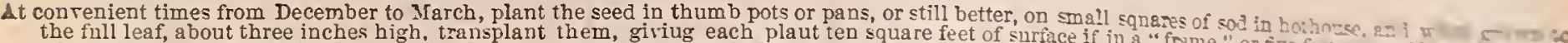

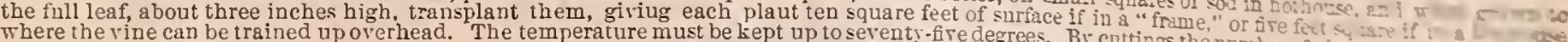

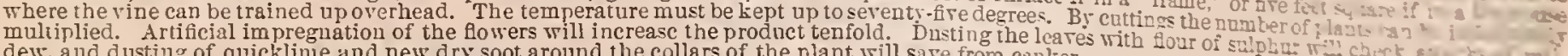
dew, and dusting of quickline and new dry soot around the collars of the plant will save from canter.

Telegraph.-A leading English hothonse rariety, quick in growth weighing up to four pouuds. White spined, haidsome and prolific. $\mathrm{P}^{-}$t. $20 \mathrm{c}$.

Tender and True. - A free-bearing, long-fruited greenhouse sort. Sometimes thirry incbes iu length, small neck, very showy in color and form. Thiu skin and firm flesh. Pkt. 20c.

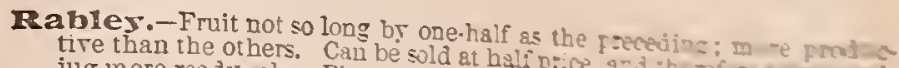
iug more ready sale. Pht. 2uc.

Biu

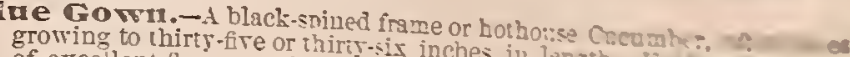

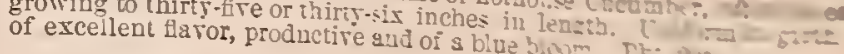

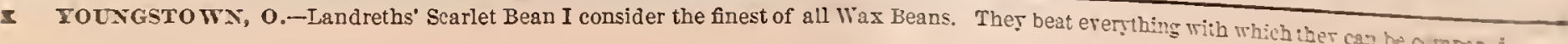




\section{CHERVIL.}

Scandix cerefolium-Cerfeuil-Perifollo-sierbel sittere-Kjorvel.

THREE. OUNCES OF SEED TO 100 YARDS OF ROW. TWENTY-FIVE POUNDS TO THE ACRE.

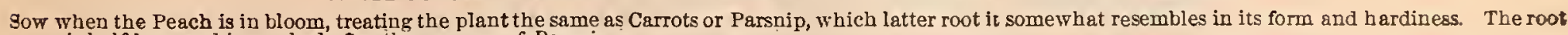
is half-Jong and is crooked after the manner of Parsuip.

Curled.-Sow and cultivate like Parsley. Used for soups and salads. Pkts. 5c. and 10c. ; per oz. 25 c. ; per $1 / 4$ lb. 70 c. ; per lb. $\$ 2.50$.

\section{CMIVES.}

Allium schonoprasum-Ciboulette-Sdnittlaum-Cibolino.

The leaves of this plaint are used for seasoning, but as a rule onl? by Euhopeans, who have brought their old country tastes with them to this country. It is similar in habit to the Onion, and it is propagated by divisions of the root tufts, which should be set out in April or May in rows of twelve inches, the sets heing placed at four iuches in the row. Yer lb. market price.

\section{CRESS.}

Lipidium Sativum-Cresson alénois-Barten=Sreffe-Mastuerzo-Tuinkers.

This is used as a Salad. It should be sown at close of Winter broadcast, or in rows at ten inches, and the sowing repeated every two weeks.

Curled.-Used for flavoring and as a Salad. Pkts. 5c. and 10c.; per oz. Water. $\mathrm{A}$ favorite dressing for dishes and a desirable form of greena 10c. : per $1 / 4 \mathrm{lb} .15 \mathrm{c}$.; per $1 \mathrm{~b} .50 \mathrm{c}$.

Broad-r,eaved. $-A$ form of Salid much used abroad. Plst. 5c. and 10c.; per $0 z .10 \mathrm{c}$; ; per $1 / 4$ lb. $20 \mathrm{c}$. ; per lh. $70 \mathrm{c}$. Pkts. ioc.; per oz. $45 \mathrm{c}$.

\section{DANDELION.}

\section{Taraxacum-Pissenlit.}

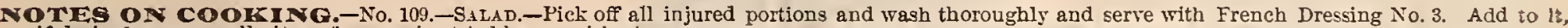
if desired, some small piece of very crisp tried bacon with vinegar.

Cabbagirg.-An improved type of an odd.fashioned plant rapidly growing into favor as an early Salad. Sow aud cultivate same as Lettuce. Tie

up the same as Cos Lettuce, or shelter from light by inrerted pots or board covering. Plt. 10c.; per oz. 80c.

\section{$E G G=P L \underline{1} \underline{N}$.}

Solanum melongtna-Aiubergine-Eierpflang-Berengena-Eierplant.

ONE OUNCE OF SEED TO 100 YARDS OF ROW.

This seed is generally sown under giass and transplanted to the field two or three weeks after Corn-planting season. The plants are set in rows of five feet and at tbree feet in the row. 'The land cannot be too highly fertilized for this crop-very short, thoroughly rotted stable manure or similar preparation is best; stroug manure or hot, rank manure is unsuitable.

Sow in hotbeds or otber protected place early in the Spring; when up two or three inches transplant into kmall pots (which plunge in earth) so as to get stocky, well-rooted plants, and late in the Spring, or not till the commencement of Summer, unless the weather be warm, tralisplant into thoroughly worked, rich and the commencement of Summer, unless the weather be warm, traisplant into thoroughly worked, rich and recently well-manured ground. A good plan is to open a deep, wide trencli, filling it nearly with mauure;
restore the earth and plaut therein. placing tae plauts three feet apart each way. The seed does not vegetate freely, repeated sowings are sometimes uecessary. It is almost useless to attcmpt the culture of Egg-Plant unless the proper attention be given. In growing the Egg-Plant in the Summer and Autumn months in Florida, great trouble is sometimes experienced 111 getting a staud of plants owing to the excessive heat and beating rains. This difficulty can be largely overcome by shading the ground where the seed is sown. If sown in heds, the shading may be accomplished by means of frames covered with seed-bed cloth, or by blinds of slats or common boards properly supported over the beds to cut off the direct rays of the sun. If the seed is sown where the plants are to remain (a had pracices the shading may be dune by using Palmetto fans or leaves. placing them one each on the liorth and soutl sides of the hill, the tops meeting over the seed.

This plan is uscd hy some of the most successul growers in the Gulf States.
About 3000 plants are required to plant an acre. These plants should produce an arerage of three to four fruits, welghing two to three pounds each. Our selected seeds are always taken from fruit weighing eight to ten pounds each; we have had them of thirteen pounds in wejght. Commissiou Alerchants iu Philarelphia pay the market gardener about, on an arerage, one-and-a-half cents per fruit. The highest prices are eight and ten cents per fruit.

Florida fruit arri ves in Philadelphia the latter part of Norember, and commands $\$ 6$ to $\$ \$$ per barrel crate.

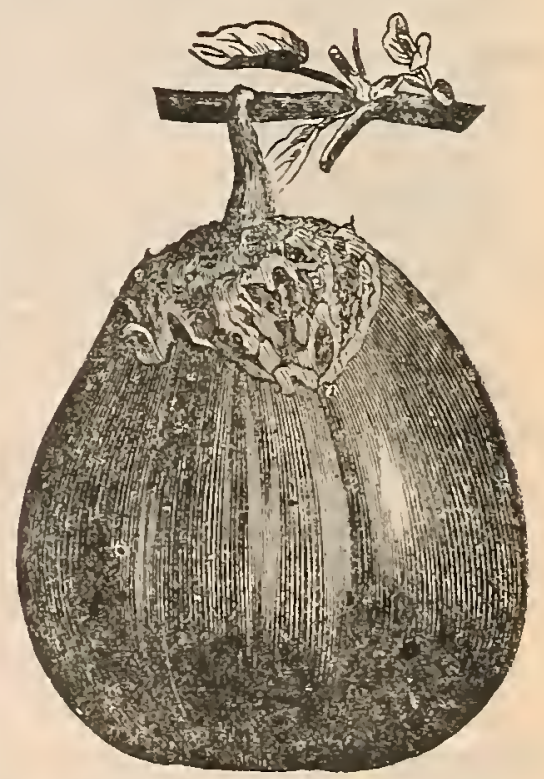

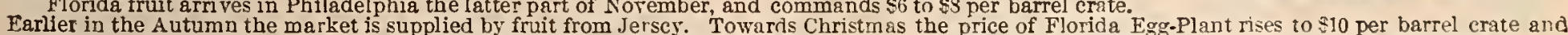

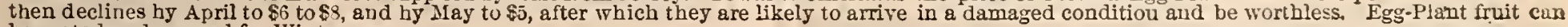
be grated and cauned for Winter use.

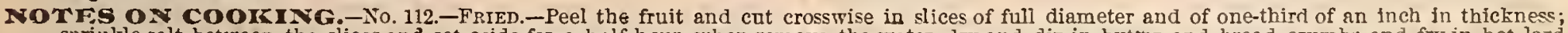

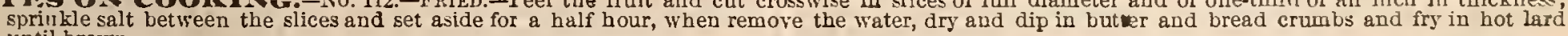
until brown.

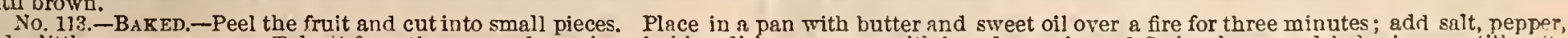

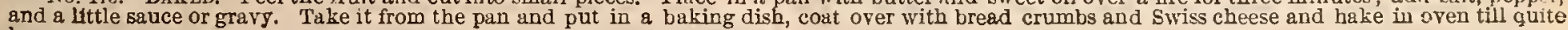
brown

Landreths * Thormless I,arge Round Purple.-Almost thornless, and theretore a sort more valuable to the tructicr than the spiny sort so often sold as the New York Improved, which, by reason of its thorns on leat and stein offer serious impediments to quick gathering The Landreth is decidedly the best selection of Egg-Plant, being productive and vigorous, oftell reaching a weight of twelve pounds. The fruit may be described as short egching a weight of lwelte pounds. The fruit often nearly equal to the length. Color (when grown ou soil of proper qualits) a deep purple, running in places almost to a black purple. Single plants of this variety often reach a span of three feet and produce severs or eight large fruits. Pkts. 5c. and 10c.; per oz. $60 \mathrm{c}$.; per $1 / 4 \mathrm{lb}$. $\$ 1.60$; per $1 \mathrm{~b} . \$ 6.00$.

New York Improved.-This is a form of the old Large Round Purnle ; large, solid, weighty and showy. Pkts. 5c. and 10e. ; per oz. b0c.: ner $1 / 4$ lb. $\$ 1.60$; per $1 b$. $\$ 6.00$.

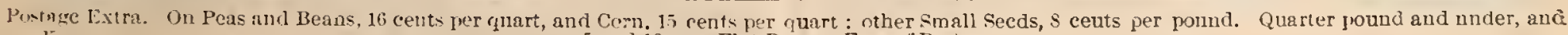




\section{ENDIVE.}

Chicorium endivia-Chicorte Endive-Enbinien=Ealat-Escarola ó Endivia-Andijvie.

TWO OUNCES OF SEED TO 100 YARDS OF ROW. THREE POUNDS TO THE ACRE.

Sow in the Spring as soon as the earth is free from frost, and repeat up till within sixty days of Autumn frost. Drill in rows of two feet and thin the flants $w$ eight inclies upart. Tie up the loose leaves or cover with pot to hlinch for Salad. Valuable for Saiads and highly decorative as a garnish to table regetabie.

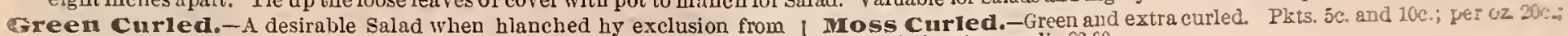
tho sun. Pkts. 5c. and 10c.; per oz. $20 \mathrm{c}$.; per $1 / 4 \mathrm{lh}$. 50c.; per $1 \mathrm{~b}$. $\$ 1.75$.

White curled. $-\Lambda$ variety of white tint, more delicate than the Green per $1 / 41 \mathrm{~b} .60 \mathrm{c}$; per $1 \mathrm{~b} . \$ 2.00$

Curled. Plzts. 5c. and 10c.; per oz. 20c.; per $1 / 4$ lb. 50c.; per $1 \mathrm{~b}$. $\$ 1.75$.

Broad Leaved.-More productire than the other rarieties: to: 60

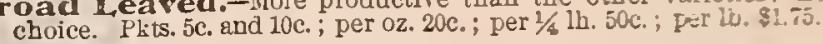

\section{GARLIC.}

Allium Sativum-Ail Ordinaire-Bemöbntider Snoblaü-Ajo Vulgar-Enoflook.

Fed in cooking for seasoning purposes. Its flavor is somewhat similar to that of the Onion, though much more pingent. It ig bulbour and is propegate 1 ty detuehing the cloves or sets and planting them iu rows oue foot apart and six inches asunder. Per $1 \mathrm{~b}$. ${ }^{25} \mathrm{c}$.

\section{MORSE-RADISH.}

Cochlearia armoracia-Raifort Sauvage-Deersteltig-Taramago.

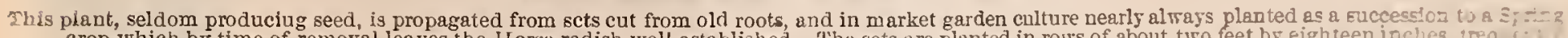
crop which by time of removal leaves the Horse-radish well established. The sets are planted in rors of about two feet by eighteen iarlies, 2 reg . among Spring Cabbage. Holes are made with a long plantiug stick into which are aropped the Horse-radish sets to a de pa

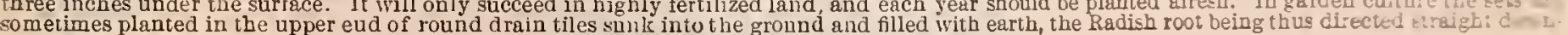
5 ards. Yield about 150 busbels to the acre. Sets, per doz. $15 \mathrm{c}$. ; per $10050 \mathrm{c}$; ; per $1000 \$ 1.00$.

\section{MERBS.}

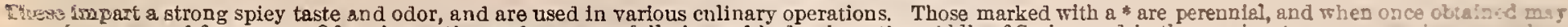

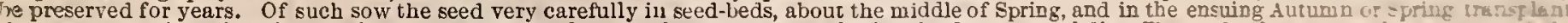

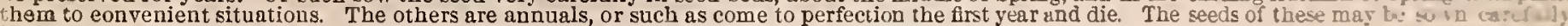

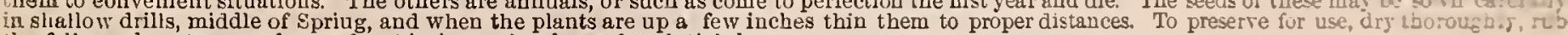
the foliuge almost to powder, and put in jars or hottles aud cork tightly.

Anise.-Pimpinella Anisum-Anis-Brüner 2[niz-Matalahuga. A Persian lant, the seeds of which are used as a condiment and in the mau ufacture biant, the seeds of which are used as a condiment and in the mauufacture of liquors and eonfectioncry. The plant itself is used as a garuish and - the manufacture of cordials. It is one of the oldest medicinal
spees. Sow the seed in eariy Spring, when the Cherry is in bloom, or mmediately after, in rows at tell inches apart, and thin to six inches. it is a delicate plant, growing to a height of a foot-and-a-half, and reach$12 \mathrm{~g}$ maturity at $\mathrm{Midsummer}$. Pkts. $5 \mathrm{c}$. and $10 \mathrm{c}$; ; per $0 \mathrm{z} .15 \mathrm{c}$.

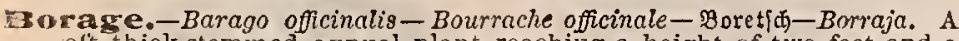
solt thiek-stemmed annual plant, reachiug a height of two feet and a read th of equal area. Leaves light green and of fuzzy character. A prorn ue bloomer. Flowers star-shaped, light hlue and quite ornamental. 'the plant is used in the manufacture of cordinls. Pkts. 5c. and 10c.; vec oz. $15 \mathrm{c}$.

Cardoon.-Cynara cardunculus-Cardeon-Aarbon-Cardo. Foliage slmllar ill appearance to the French Artichoke. The leaf stalks, as those of the Artichoke, are blanched, and are used stewed in soup and as a salad. The seed should be sown in the early Spring, and in rows of three feet apar, and the plauts thinned to one foot. In Auturn the stalks should a blanched the same as Celery. Pkts. 5 c. aud 10c. ; per 0z. $40 \mathrm{c}$.

Notes on Cooking Cardoon.-No, 47.-STEwED.-Remove the soft malks and prickly edges, cut four inches in length and parboil for twent uidutes, cool, peel sud put in a saucepan, cover with light hroth whitmiautes, cool, peel sud put in a saucepal, cover with light hroth whitboil until soft, drain through a llapkin, range in a deep dish and add butter. Serve with Espagnole sauce. See No. 69.

GHraway.-Carum carui-Carvi-Felb=ภïmel-Karvij. The seeds are used iu flavoring bread, pastry and sauce, and sometimes in cheese making. Sow in drills, when the Cherry is ill hloom, at three feet, and thin to six inches. The foliage of this plant resembles that of a Carrot. It has a height of about one foot and continues iu growth until stopped hy srost. Pkts. $5 \mathrm{c}$ and 10c.; per $0 \mathrm{z} .15 \mathrm{c}$.

exizervil.-Scandix cerfolium-Cerfeuil-Perifnllo-Serbel-Kjorvel. When the Peach is in bloom sow, treating the plant the same as Carrots or ParThe root is half-long, and is crooked after the manner of Parsnip. Used for soups and salads. Pkts. $5 \mathrm{c}$. and $10 \mathrm{c}$. ; per oz. $25 \mathrm{c}$, ; per $1 / 4 \mathrm{lb}$. $70 \mathrm{c}$.; per ib. $\$ 2.50$.

Coriand er.-Corianirum sativum-Cariandre-corianber-Culantro. The seeds are used in the manufacture of liquors, and in culinary operations. seeds are used in the manufacture of liquors, and in culinary operations. cen inches, thin to six inclies. An carly maturing plant, reaching a ielght of two feet, and prolific in very palatable seeds. Pkts. 5e. and 10c.; jer oz. 15c.

Dill.-Ancthum graveolens-Aneth-Dill-Ensldo. The seeds of this plant are ased in the fuvoring of preserves and rickles, alon as a conitiment. It has a lavor similar to that of mint. Sow the seed when the Cherrs is in loum, in rows of eighteen inches and thin to five inches. Pkts. 5c. and

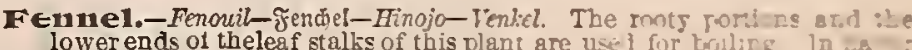
it resemble Celery, and is used in the mallufacture of lic $12 \mathrm{x}$. seed when the Cherry is in bloom, in drills of cightery webes a.d in to six inches. Pkts $5 \mathrm{c}$. and $10 \mathrm{c}$; ; per $0 \mathrm{z}$. $15 \mathrm{c}$

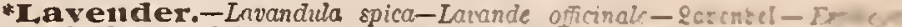
The leaves of this plant are used for seasoluing, and the $z$ ucr: i a t fumery. The plant is propagated principally by is from cald $I$ - is is a slips are placed in rows bree feet apart and onc font in the $I \mathrm{~N}$. If $\mathrm{L}$ seed is sown it should be planced when the Apple is iu tound Plate is and $10 \mathrm{c}$; per oz $20 \mathrm{c}$

* I osemary.-Posmartnus officinalis-Romarin-Moi-cosio- $\delta$

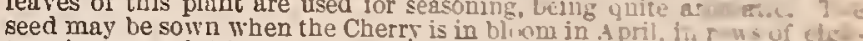

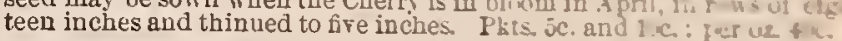

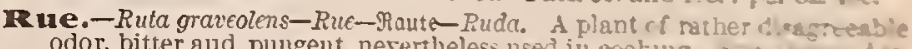
odor, bitter aud puugent, nerertheless nsed in cooking. y th yed ig April, in rows at two feet and thin to sis iuches Plis aco aic lw: : :

* Sage.-Salvia officinalis-Sauge offinale-Ealkci-Sairia, njeof the cidest cultivated garden herbs used for seasoning and dis bi s:u the Cherry is in bluom in one-foot rows, and whell sile st wisto thin to six inches between the planis. The flaut rea ta b o i t

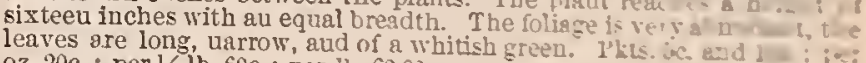
oz. $20 \mathrm{c}$; ; per $1 / 4$ ib. $60 \mathrm{c}$; ; per lb. $\$ 2.0 \mathrm{x}$

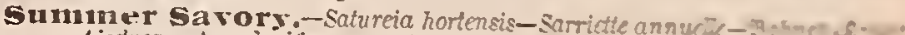
- Ajediea. An odoriferons garden herb used in seasonit

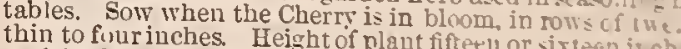
multitnde of straight stems, foliat fiftetll or sixfect it $\mathrm{ch}$. . is a PLts. 5c. and 10c.; per 0z. $15 \mathrm{c}$.

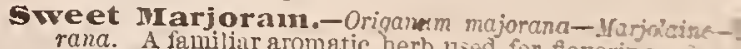
rana. A familiar aromatic herb used for fiaroring. Sor the Cherry is iu bloom, un one foot rows in early sirin per oz. $20 \mathrm{c} ., ;$ per $1 / 41 \mathrm{~b}$. $60 \mathrm{c}$.; per $1 \mathrm{~b}$. $\$ 2.00$. Au aromatic herb used for farlicum-Easilic Grand- plaut growing to a height of two feet and of equal in is a . ing in growth until killed by frost. When the cber

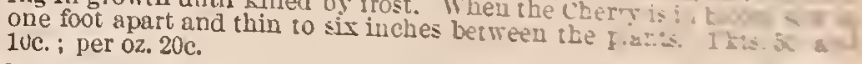

*Thyme.-Thymus Vulgaris-Thum ordinairs- If--.. leaves and young shoots are used in seasouing and in fifteen iuches for boe culture, and when the Cherr is it b This piant reaches a height and wo feer and a lis of $f$ This piant reaches a height of eight inches to che foor a

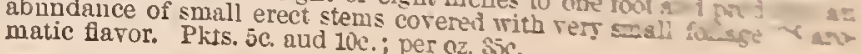




\section{LETTUCE.}

Lactuca capilato-Laitues pommées-Sopffalat, Sattí-Lechuga acogollada-Krop salad

TWO OUNGES OF SEED TO 100 YARDS OF ROW. FOUR POUNDS TO THE ACRE.

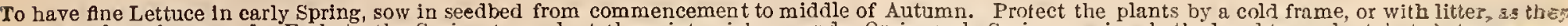

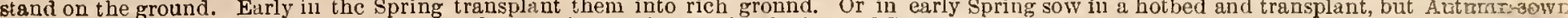

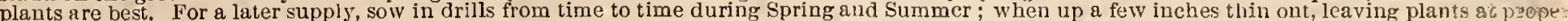

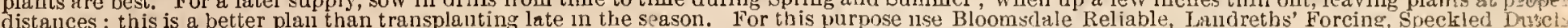

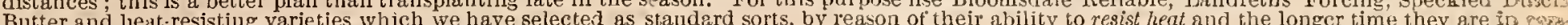
dition for the table than some other kinds which shoot to seed as soum as the head is formed.

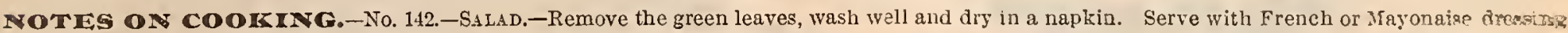

I,andreting' Earliest Cutting.-The earliest cutting variety in market. Nlay be plunted very close. It does not liead, but affords curled, crisp, good-flavored to head Pkts. 5c. and 10c.; per oz. $20 \mathrm{c}$; per $1 / 4$ lb. $50 \mathrm{c}$.; per 1b. $\$ 1.75$.

C,and ret11s' Forcing (RARE). - Valuable for smal gardens. This is something very choice, and while most trusty for open garden culture, it is uuapproached for forcing in hotueds or frames; exceedingly early, compact habit, adınitting of close culture; heads small, but very pretty and saluble. Very compact and round like a ball suitable for sonding to the table in entive form on the root. Loung stunding betorc shooting. Pkts. 5c. and $10 \mathrm{c}$. per oz. $25 \mathrm{c}$.; per $1 / 4$ 1b. $70 \mathrm{c}$.; per 1b. $\$ 2.50$.

Black Seected Simpson.-A cutting variety of inusual merit-not so golden as silesian, but by some prcferred. Pkts. 5 c. and $10 \mathrm{c}$; ; per oz. 15c.; per $1 / 4 \mathrm{lb}$. 35e.; per $1 \mathrm{~b} . \$ 1.25$.

Curled Simpson.-A cutting variety similar to and immediacly following the Silesian. Pkts. 5c. and 10c.; per oz. 15 c. ; per $1 / 4$ lb. 35c. ; pcr lb. $\$ 1.25$.

Early Curled Silesian.-A cutting variety; the second to prodnce coible leaves. It does not head. Pkts. 5c. and 10c.; per oz 10c.; per $1 / 41 \mathrm{~b}$. 30c. ; per $1 \mathrm{~b} . \$ 1.00$.

Boston Car1ed-Pkts. 5c. and 10c.; per oz. 15c.; per $1 / 41 \mathrm{~b} .35 \mathrm{c}$; ; per $1 \mathrm{~b}, \$ 1.25$.

Tennisbail (BIACK SEEDED). - An early heading sor of reputation. Pkts. 5 c. and 10c.; per oz. $15 \mathrm{c}$. ; per $1 / 4 \mathrm{lb}$. 35 c. ; per lb. $\$ 125$.

Tennisba11 (WHITE-SEFDED)-Pkts $5 \mathrm{c}$ and $10 \mathrm{c}$; per oz. $15 \mathrm{c}$.; per $1 / 4$ lb. $35 \mathrm{c}$.; per lb. $\$ 1.25$.

Bak-I,eaved. - Named because of its resemblance. Excellent for hot countries, as it resists almost any heat. Pkts. 5c. and 10c.; per oz. $15 \mathrm{c}$.; per $1 / 4$ lb. $45 \mathrm{c}$.; per $1 \mathrm{~b}$. $\$ 1.50$.

Bogton NIarket.-Pkts. 5c. and 10c.; per oz. 15c.; per $1 / 4$ lb. $45 \mathrm{c}$; per lb. $\$ 1.50$

VIrginia Solld Yeader. $-A$ white Lettnce of cabbage form. cultivated by us on our Virginia plantation for shipment to marlet, and of remarkably good quality. Last April and May we seut quantities to Baltimore market realizing hand April and Iay we sent quantities to Baltimore market, realizing handsome prices, and next year will put in a
wide breadth for truck. We recommend it by using it ourselves. Pkts. wc. and 10c. ; per oz. $25 \mathrm{c}$.; per $1 / 4 \mathrm{lb}, 65 \mathrm{c}$.; per $1 \mathrm{~b} . \$ 2.25$.

Bloomsciale R eliable.-A medinm-sized Cabbage rariety, never failing to head, slow to shoot to seed, and in all respects one of the best sorts ever introduced. Thin leaf, close folded head, few outside leaves, quick in growth. Recommended to market gardener: for forcing

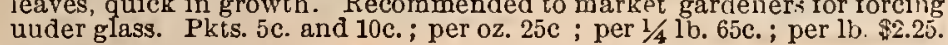

Dalamander.-Pkts. 5 c. and $10 \mathrm{c}$; per oz. $15 \mathrm{c}$. ; per $1 / 4$ lb. $35 \mathrm{c}$; per $1 \mathrm{~b}$. $\$ 1.25$.

American Gathering.-A curlr-leaved, bronze-edged sort. Pkts. 5c. and 10c.; per oz. $15 \mathrm{c}$.; per $1 / 4$ lb. $35 \mathrm{c}$. ; per lb. $\$ 1.25$

Prize Yead, or Satisfaction.-A cutting variety of curly leaves. Pkts. 5c. and 10c.; per oz. $15 \mathrm{c}$.; per $1 / 41 \mathrm{~b}$. $35 \mathrm{c}$.; per $1 \mathrm{~b} . \$ 1.25$

Golden Curled. - New sort. A golden-leaved sort producing a hal head of rare excellence; leaves much fluted on the edges; very showy and a m.st admirable cutting sort. Pkts. 5c. alld 10c.; per oz. 20c.; per $1 / 4$ lb. 50 c. ; per 1 b. $\$ 1.75$.

Bronzed Curled.-New sort. A half-cabbaging variety of bronzeedged leaves, and superior to either Prize Head or American Gathering. Pkts. 5c. and 10c. ; per 0z. $20 \mathrm{c}$. ; per $1 / 4 \mathrm{lb}$. $50 \mathrm{c}$. ; per 1b. $\$ 1.75$.

Tarison.-Pkts. 5c. and 10c. ; per oz. 10c. ; per $1 / 4$ lb. $30 \mathrm{c} ;$ per lb. $\$ 1.00$.

Curled India.-A valuable variety, making a close-folded head. Stands the sun and is crisp and tender. Pkts. $5 \mathrm{c}$. and 10c.; per oz. 15c.; per $1 / 4$ 1b. 35 c. ; per 1 b. $\$ 1.25$.

Bpecikied Dutch Butterhead (SECOND EARLY).-A long-standing white Cabhagevariety, forming quite compact heads, the leaves possersing the peculiarity of being irregularly dotted with spots resembling iron
rust. This is the favorite variety with market gardeners in the neighborhood of Philadelphia. Pkts. $5 \mathrm{c}$. and $10 \mathrm{c}$; ; per $0 \mathrm{z}$. $15 \mathrm{c}$.; per $1 / 4 \mathrm{lb}$. $45 \mathrm{c}$. per Ib. $\$ 1.50$.

Imperial Cabbage.-A showy white cabbaging variety of very choice quality, uniform in character, and in every particular very

superior to the stock usmally sold as Imperial or White Cabbage. Pkts. $5 \mathrm{c}$. and 10c.; per Oz. $15 \mathrm{c}$. ; per $1 / 4 \mathrm{lb} .45 \mathrm{c}$. ; per $1 \mathrm{~b} . \$ 1.50$

Early White Cabbage (SECOND EAPLY).-A broad-leaved, vigorousheading sort. White. showy and desirable. Pkts. 5c. and 10c.; per oz. $15 \mathrm{c}$; per $1 / 4$ lb. $35 \mathrm{c}$.; per $1 \mathrm{~b} . \$ 1.25$.

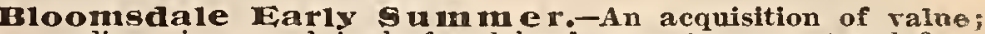
medium tize round in leaf and head; smooth, compact oud firm: alway heading and slow to shoot to seed; qualities which com mend themselves to all who aim to raise Lettuce either for family use market. Second early in maturity. We cannot recommend it too highly. Known in the vicinity of New Orleens as the Creole. DON'T FAIL TO TRY II. Pkts. 5c. and $10 \mathrm{c}$. ; per oz. $20 \mathrm{c}$. ; pcr $1 / 4 \mathrm{lb}$. $50 \mathrm{c}$. ; per $1 \mathrm{~b} . \$ 1.75$

Royal Cabbage.-Large heads, compact, crisp, desirable. Plts. $5 c$ and $10 \mathrm{c}$; ; per oz. $15 \mathrm{c}$.; pci $1 / 41 \mathrm{~b}$. $35 \mathrm{c}$. ; per $1 \mathrm{~b} . \$ 1.25$.

Largest of A11.-Wrgnificent heads, coveted by all who see them. A very large green cabbaging variety, very bold, altogether desirable, both for family use and market garden. Truckers can adopt it with conf dence, as it is surc to scll. Pkts. $5 \mathrm{c}$. and $10 \mathrm{c}$. ; per oz. $30 \mathrm{c}$. ; per $1 / 4 \mathrm{lb}$. $85 \mathrm{c}$. per lb. $\$ 300$.

H10omsdale Ifutter (BLACK SEED).-A dark grecn-leaved variety o* remarkable vigor, resisting the most severe heat, aud highly prized by all
who have tried it. Userl largeiy by market gardeners. Pkts. $5 \mathrm{c}$. and loc. per oz. $20 \mathrm{c}$.; per $1 / 4$ lb. $50 \mathrm{c}$. ; per $1 \mathrm{~b}$. $\$ 1.75$.

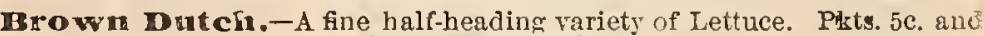
10c. ; per 0z. 15c. ; per $1 / 4$ lb. 35c. ; per $1 \mathrm{~b} . \$ 1.25$.

New York l.etruce.-A large, late variety of peculiar green colo Pkts. 5c. and 10c. ; per oz. $15 \mathrm{c}$. ; per $1 / 4 \mathrm{lb} 35 \mathrm{c}$; per $1 \mathrm{~b} . \$ 1.25$.

Handretlis' Heat-ISesisting Cos.-Vigorous, always herdins erisp, never wilting uuder the sercrest sun. Remarkably fine. It shouls be in every garden. Pkts. 5c. and 10c.; per oz. $20 \mathrm{c}$; per $1 / 4$ lb. $50 \mathrm{c}$.; pes

Greell Cos.-Pkts. 5c. and 10c. ; per 0z. 15c. ; per 1/4 lb. 35c. ; per $1 \mathrm{~b} . \$ 1.25$

White Cos.-An old variety, highly esteemed. Habit of growth upright The leaves require tring up to insure blanching. Pkts. 5c. and 10c.; pes oz. $15 \mathrm{c}$. ; per $1 / 4$ lb. $45 \mathrm{c}$. ; per lb. $\$ 1.50$. 


\section{KALE}

Brassica Oleracea-Acephala-Choulx verts-Minter=Roghl-Coles Sin Cogollo.

ONE OUNCE OF SEED TO 100 YARDS OF ROW. FOUR POUNDS TO THE AURE.

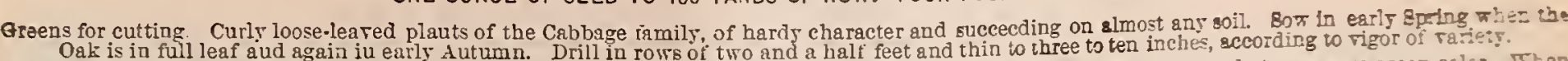
nearly cooked tender, be cooked same as Cabbage. with pork, ham and corn beef-the hale to remain natural-that is, entire.

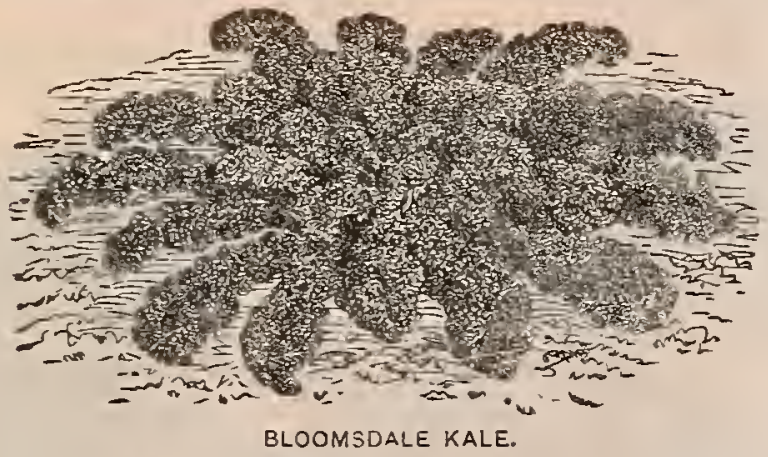

QLOOMSDALE KALE.Leaves, moss curled ; color, emerald green; height ten inches when full grown; appearance at a distance like Curled Parsley. Pkts. 5c. and 10c.; per oz. 25c.; per 1-4 lb. 65c.; per Ib. $\$ 2.25$.

Rosette. - The most densely foliaged Kale in cuittration, forming a loose head or rosette, most ornamentai and most profitable to the market gardener. Leaves, strong, wide, ercet, recurved, cxquisitely curled and twisted, so much fluted on the edges as when unfolded to astonish by cope of the leaf four times the usual span. color, light green, veins and ribs marrow like, stems short, plant rising to a height of elgt: 1sctes Ficeedingly slow to shoot to seed; a raluable quality wo the rarise: $8 \mathrm{~s}$ :

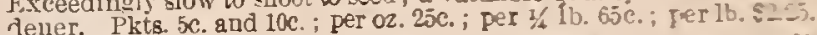

Dwarf Extra carled German Greens. $-A$ rariers of $1300^{\circ}=$ ? war forman Greens, and much cu-led. Plos 50 gnd 10c.; per oz. 15c.; per $1 / 4$ lb. $35 \mathrm{c}$; ; per $15 . \$ 1.25$.

Toshach.-In height between the Drarf Scotch and the Extra I wr

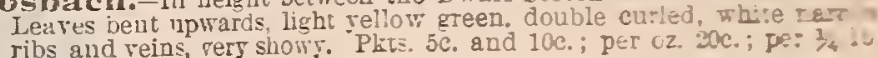
50c.; per lb. $\$ 1.75$.

Wor folk. -Color, rerr light green, leares much caried. Pkts, 5c. ex? 10c.; per oz. 15c.; per $1 / 4$ 1b. 4 je.; per lb. S

Purole Dwarf German.-Height four to of lo loches 80 w t] $p$ manent position. Plts. 5c. and 10c.; per 0z. 15c; peris ib. 4 ic. ; jer 1 $\$ 1.50$.

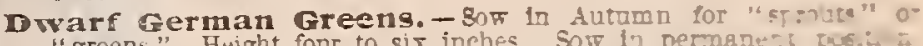
"greens." Height fonr to six inches. Sow 37 permeneris gues. PEts. 5c. and 10c.; per oz. 10c.; per $1 / 41 \mathrm{~b}$. 25c.; per $1 \mathrm{~b}$.

Gew orleans Broad Leaf.-Ennrmous!y port intre in brod aes lenve, dark green in color. rert thick in testure. pon ti a le so ibo shipper. Plts. $5 c$. and 10c., per oz. 10c.; per $2 / 41 \mathrm{~b}$. 2uc if ilb. .

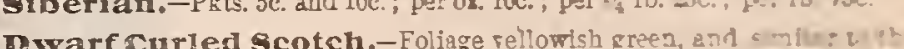

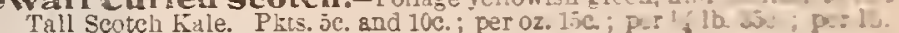
\$1.25.

'all Curled gcotch.-Manage ag Winter Cabbaze. Tedrable :دs Wiuter nse. Height tro to four teet. Sow in beis a i transpiund Pred 5c. and 1uc.; per $0 z .15 c$., per $2 / 41 b$. 35c.; per lb. \$1:as.

\section{$\mathrm{KOML}=\mathrm{R} \mathbb{A} \mathrm{B}$.}

Brassica Caulo-rapa-Choux-raves-Sinollerlob[-Cavolo-rapa.

ONE OUNCE OF SEED TO 100 YARDS OF ROW.

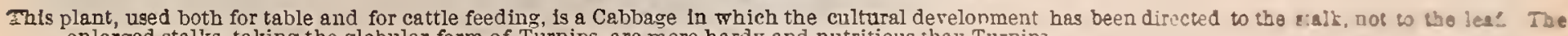
enlarged stalks, taking the globular form of Turnips, are more hardy and nutritions than Turnip

Ally good soil will produce a crop, the plants for which may be grown like Cabbage iu seed beds for transplanting, or eown !a re $m a z e=i$, al: on In three-feet rows.

Si) w the seed for table use at anT period when Cabbage may be sown. Drill in rows at two feet and thin to six inches.

For cactle feeding drill the seed iu Ifidsummer for Autumn dcrelopment. Yield 300 to 400 bushels to the acre

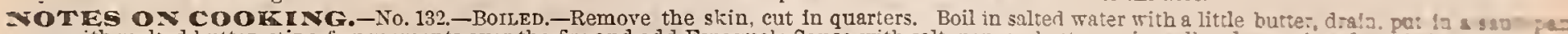
with melted butter, stir a few moments over the fire and add Espaguole Sauce with salt, pepper, butter; mix well and serve in a dep di. $h$.

White Vlemma.-Short leaved, bulb light green, very rapid in growth,

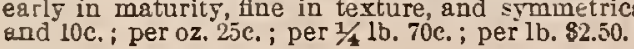

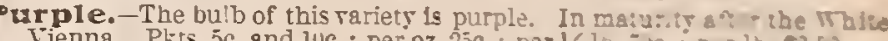

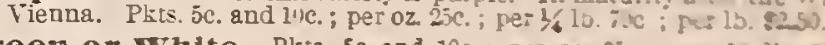

Green or White.-Plits. Sc. and $10 \mathrm{c}$; pe: $02.2 \mathrm{c}$; per 2 is ic. per lb. $\$ 2.50$

\section{LEEK.}

\section{Lium porrum-Poireau-Eaud ober Porre-Puerro-Pret.}

TWO OUNCES OF SEED TO 100 YARDS OF ROW. FOUR POUNDS TO THE ACRE.

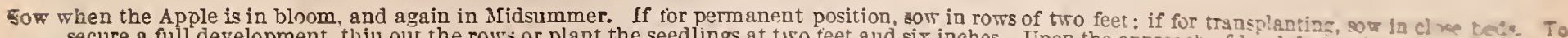

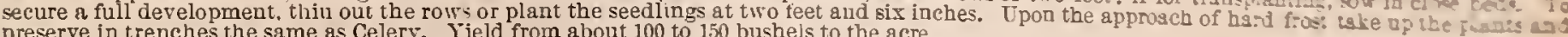

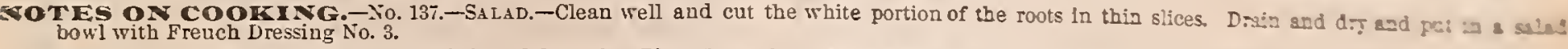

Carentan.-Very superior, large rooted, broad leared. Plts. 5c. and ;uc. ; per 0z. 20c.; per $1 / 4$ lb. $60 \mathrm{c}$. ; per lb. $\$ 2.00$.

ao uen.-Thick short stem with numerous fan-shaped leaves. Pts. $5 \mathrm{c}$.

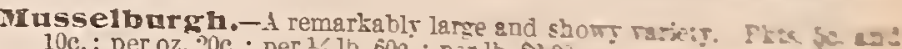
10c.; per oz. $20 \mathrm{c}$; ; per $1 / 1$ b. 60c. : per lb. $\$ 2.0$.

and 10c. ; per 0z. 20 c. ; per $1 / 4$ lb. 60 c. ; per lb. $\$ 2.00$.

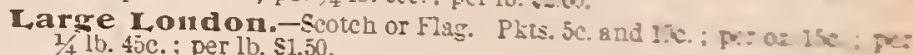

\section{BORDEAUX MIXTURE.}

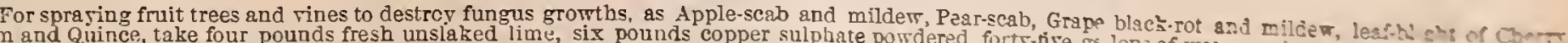

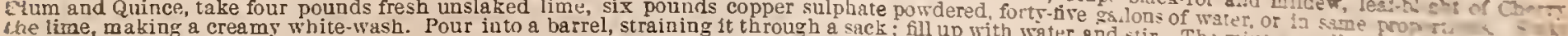

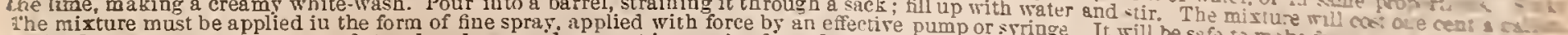

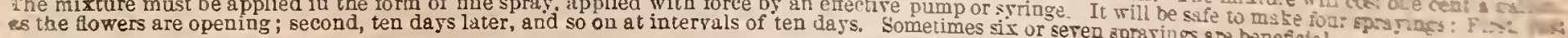




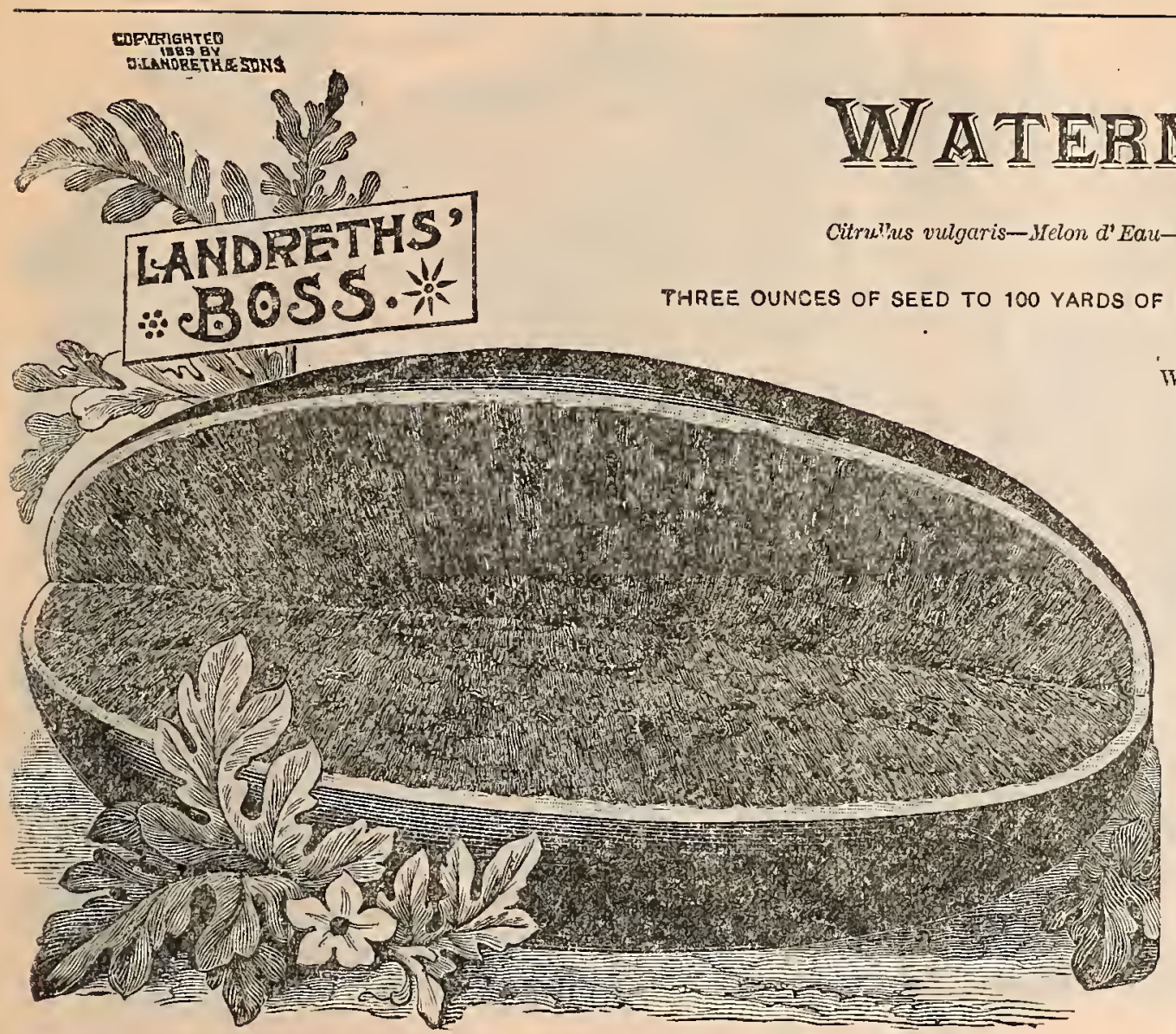

Watermelons do well upon sod ground or upon land prcpared for their reception by plowing down a crop of Winter wheat or Winter rye, the sod or grain aerating or kceping loose the soil. When the Apple is in broom the seed is planted in hills at ten feet apart in each dircction. Two large shovclsful of well-rotted stable manure dug and tram

The cultivator should be prepared with quite four pounds of seed to the acre that lie may have a reserve for replanting iu case of destruction of his plants by insect depredations or beating rains.

One vine alone to the hill should be allowed to attaiu perfection. with four hundred and fifty hills to the acre, there should be niue hundred first-class Melons.

Philadelphia Commission Mcrchants pay for prime Melons, as a highest price, forty dollars (\$40.00) per hundred. As an average price, ten dollars per hundred. They cease to be profitable to the trucker when oringing less than four dollars per hundred. First-class ilelons are always in demand, but the market is frequently overstocked with small fruit

Nuch of the Melon seed offered throughout the country is the product of immature and deformed Melons remaining in the field after all the choice fruit has been selected.

Extra Early,-Quite desirable as the first Watermelon to ripen. Form oblong. Weight from eighteen to tweuty pounds. Color green dashed witl white. Quality very good. Psts: 5c. and 10c.; per oz. 15c.; per $1 / 4$ lb. $45 \mathrm{c}$. ; per $1 \mathrm{~b} . \$ 1.50$.

Scaly Iark. $-A$ mottled Melon of early maturity. Pkts. 5c. and 10c.; per oz. 10c. ; per $3 / 4$ lb. $25 \mathrm{c}$; per $1 \mathrm{~b} .75 \mathrm{c}$.

I, ight Green $\mathbb{R}$ ind Icing.-One of the BEST OF ALL Melons; always of good flavor, rind very thin. UNEXCELLED IN ALL GOOD QUALITIES. Pkts. $5 \mathrm{c}$. and 10c.; per oz. 10c. ; per $1 / 4$ lb. $25 \mathrm{c}$; ; per $1 \mathrm{~b}$. $75 \mathrm{c}$.

park Green Rind Icing.-Shape, size and flavor same as Light Icing, but dark skinned. Pkts. 5c. and 10c.; per oz. 10c.; per $1 / 41 \mathrm{lb} .25 \mathrm{c}$. ; per $1 \mathrm{~b} .75 \mathrm{c}$.

Ice Cream.-Form oblong, skin light in color, seeds white, flesh solid aud red. Pkts. 5c. and 10c.; per 0z. 10c.; per $1 / 4$ lb. $25 \mathrm{c}$.; per lb. $75 \mathrm{c}$.

Peerless.-Good, but not equal to the Ice Cream. Rind thin, light green; flesh solid, bright in color, sugary. Pkts. 5c. and 10c.; per oz.10c.; per $1 / 41 \mathrm{~b} .25 \mathrm{c}$; p per $1 \mathrm{~b} .75 \mathrm{c}$.

Land reths' Eong Iight Eciug.-A good cropper, heavy, attrac. tive, and very desirable in quality. Pkts. $5 \mathrm{c}$. and $10 \mathrm{c}$; ; per $02.15 \mathrm{c}$.; per $1 / 4$ 1b. 3 äc. ; per $1 \mathrm{~b} . \$ 1.25$.

Gray Thomarch (Jordan's).-Long, large, heary, flesh solid, deep red and of good flavor. Pkts. $5 \mathrm{c}$. and $10 \mathrm{c}$; ; per $02.10 \mathrm{c}$; ; per $1 / 4 \mathrm{lb} .25 \mathrm{c}$; per
lb. $75 \mathrm{c}$.

Seminole.-This Melon resembles the Landreths' Long Light Icing. Pkts. 5c. and 10c.; per oz. 10c.; per $1 / 4$ lb. $25 \mathrm{c}$.; per $1 \mathrm{~b} .75 \mathrm{c}$.

Mountain Sprout.-An old variety, early and productive. Pkts. 5c. and 10c.; per oz. 10c.; per $1 / 4$ lb. $25 \mathrm{c}$; ; per $1 \mathrm{~b}$. $75 \mathrm{c}$.

Arlkansas Traveler (SPECIALTY).-A large, long, weighty Melon. Rind dark green, wilh waving stripes of black; interior always solid, the edible portion extending to within half an inch of the skin, flesh brilliant red, sweet, tender, crystalline, very juicy and altogether quite superior. Secds very small and distinct. Ripening as an intermediate. A very hard rind aud therefore a good shipper. No better Melon, except the Boss, has ever been offered to lovers of choice Watermelons, in size it is not a mammoth-no large Melons are first-class in quality. In color of tlesh it is deepest red, in texture crystalline, in flavor sugary. The flesh is solid thronghout, without any sign of either core or cavity, and the edible portion extends to within a half inch of the skin. We cannot say enough in praise of the Arkansas Traveler. Pkts. 5c. and 10c.; per oz. 1 c. ; per $1 / 4$ lb. $45 \mathrm{c}$. ; per lb. $\$ 1.50$.

Gem (KolB).-Pkts. 5 c. and 10c. ; per oz. 10c.; per $1 / 4$ lb. 20c. ; per 1b. $60 \mathrm{c}$.

Jackson, Gypsy, Rattlesnake.-A famous Melon in the Southeru States. Plats. 5c. aud 10c.; per oz. 10c.; per $1 / 41 \mathrm{~b}$. 20c.; per lb. $60 \mathrm{c}$.
Foumtain Sweet.-Pkts. 5c. and 10c.; per oz. 10c.; per $1 / 41$ lb. 25c.; per lb. $75 \mathrm{c}$.

Jameg Fiver.-A long dark-rind Melon of second size, similar to the Jones Melon. Pkts. 5c. and 10c. ; per 0z. 10c.; per $1 / 41$ b. $25 \mathrm{c}$; ; per $1 \mathrm{~b} .80 \mathrm{c}$.

Georgia.-Pkts. $5 \mathrm{c}$. and 10c. ; per oz. 10c. ; per $1 / 4$ lb. 20c. ; per 1b. $60 \mathrm{c}$

Dixie.-Grown largely during the Summers of 1891, 1892 and 1893 as a market Nelon and with unexampled satisfaction. It will supersede the Kolb Gem, compared with which it is infinitely better, viue vigorous, equally early, quite as productive, weighs as much, darker in rind, in form long to half long, flesh deep rcd without core or cavity, more melting and of very superior flavor. For shipment to long distances it will be found equal to the Kolh Gem its riud fully as strong and in appearance more showy, placing it in the first rank as a market Melon. Pkts. 5c. and 10c.; per 02. 10c.; per $1 / 4$ lb. $20 \mathrm{c}$; ; per $1 \mathrm{~b} .60 \mathrm{c}$.

Green and Gold.-So named by reason of its green rind and vellow flesh. Pkts. 5c. and 10c. ; per 0z. 10c.; per $1 / 41 \mathrm{lb}$. $30 \mathrm{c}$; ; per 1h. $\$ 1.00$.

Iron Clad.-Pkts. 5c. and 10c.; per 0z. 10c.; per $1 / 4 \mathrm{lb} .25 \mathrm{c}$. ; per $1 \mathrm{~b} .75 \mathrm{c}$.

Excelsior.-A large, showy Melon, similar to the Cuban Queen. Pkts. 5c. and 10c.; per oz. 10c.; per $1 / 4 \mathrm{lb} .25 \mathrm{c}$. ; per lh. $80 \mathrm{c}$.

Florida Favorite.-A popular Melon in the South. Pkts. $5 \mathrm{c}$. and 10c.; per. oz. $10 \mathrm{c}$. ; per $1 / 4$ lb. $25 \mathrm{c}$.; per $1 \mathrm{~b} .80 \mathrm{c}$.

Cuban Queen.-A Melon of mammoth size, reaching very often over sixty pounds in weight. Pkts. 5c. and 10c. ; per oz. 10c. ; per $1 / 4 \mathrm{lb} .25 \mathrm{c}$. per $1 \mathrm{~h} .75 \mathrm{c}$.

Pride of Georgia.-Pkts. 5c. and 10c. ; per 0z. 10c.; per $1 / 41 \mathrm{~b} .25 \mathrm{c}$. ; per $1 \mathrm{~b} .75 \mathrm{c}$.

Lavndreth's Boss. - We still adhere to our claim that no Melon has ever been introduced which can be compared with the Boss in delicgey of favor, dazaling brilliancy of color of fesh, solidity of fiesh, depth of flesh, melting quality and everything roing to male a perfect Melon. hesh, melting quality, and everything going to make a perfect Melon. inch of the pkin, and thet the rigd is so hard that no Melon in existence is so good a shipper. Perfectly ripe Melons will support the weight of a heavy man without any injurs to the interior. Success with the Boss, however, is only met with when the soil is strong and rich, botb natur. ally and artificially, and it requires a space of nine by nine or nine by ten feet to the hill. Under good conditions 4 elons weigh from thirty to forty pounds. and we have had frequent icports of them reaching a weight of sixty and seventy pounds to the Melon. True stock can only we had direct from us. Pkts. $5 \mathrm{c}$. and $10 \mathrm{c}$; per $0 \mathrm{z}$. 10c.; per $1 / 1 \mathrm{~b}$. 30c. per lh. $\$ 1.10$.

Black Ifalian.-Pkts. 5c. and 10c.; per oz. 10c.; per $1 / 4$ lb. 30c.; per lb. $\$ 1.00$.

Preserving citron,-A round, light and dark striped Watermelon, used for preserving only. Pkts. jc. aud 10c. ; per $0 z$. 100 ; per $1 / 41 \mathrm{~b} .25 \mathrm{c}$.; per 1b. 75c. 


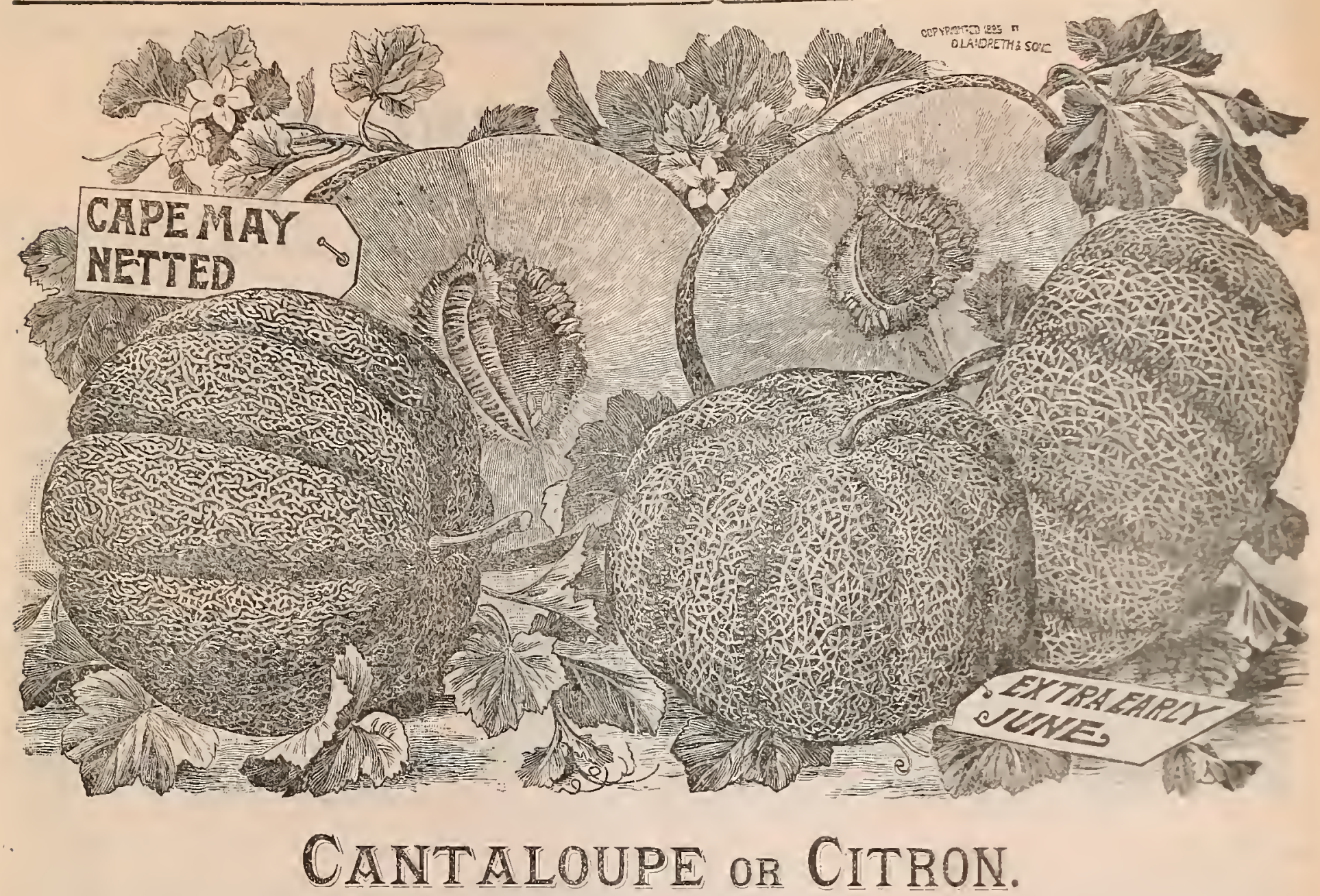

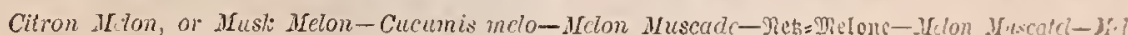

TWO OUNCES OF SEED TO 100 YARDS OF ROW. FOUR POUNDS TO THE ACRE.

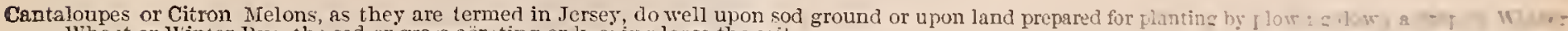
Wheat or W'inter Rye, the sod or grass aerating or leeping loose the soil.

The seed is planted at about Corn-seeding rime or when the Apple is in blonm, in lills about four-an:i-

vell-rotted stable manure being tramped in to each hill and covered with earth. The large long Nelons,

Philadelplia Commission Mlerchants pay as a highest price $\$ 1.50$ to $\$ 2.00 \mathrm{per}$ bushel

Mclons arc frequently a drug in the murket.

Extra Early Citron (FINST IN MARKET).-The laigest $o$ the very carly antaloupes; furm half flat. fairly webbed, flesb greell. The merit of this sort consists in its extra enrl bubit. A variety which, for its early maturity, will be found profitable by all market gardeners. A cnstomer writes: "I was once poor, now l am rieh - have a fine house and a laigc family. all from your Extra Early Citron." Pkts, c. and c.; per oz. c.; yer all from your Extra Ear
1/4 1 b. c.; per 1 b. $\$$.

Jenny Lind.-A very small, early variety, flattened at the poles, of surpassing good quality, recommended for family galden, rather small for market. Pkts. 5c. aud 10c.; per 0z. 10c.; per 1/4 lb. 30c.; per $1 \mathrm{~b} .90 \mathrm{c}$.

Extra Early June.-A large, flat, early Nelon following the Extra Early. Fruit more flat than the Jenny Lind, decply ribbed, heavily netted ; Hesh green, of a most exquisite quality. Thi Mielon will probably take its place as a standard cxtra early. It does best on liort soils : wil eren develop perfectly on whitc sand. It is the earliest Melon of its size aud valuable to the shipper. Twice as long as Jenuy Lind. Pists. c. and c.; per oz. c.; per $1 / \frac{1}{4}$ lb. c.; per lb. $\$$.

Extra Early Cape Bray.-A very carly and large ronnd Cantaloupe or Musk Melon of mutmeg form; quality most excelleut and exceedingly productivc: 1ruit deeply ribbed and hwavily netıed. Hesh deep green, tender, juicy. very sweet ; foliage very small and distinct and proof against sunshine. produring well on ligh test snils, and a most prolifie sort for the warket gardener, as thirty will often fill a barrel. Plits. 5c. and 10c, per oz. $15 c . ; p \in r^{1 / 4}$ lb. 45 c.; per 1 b. $\$ 1.50$.

Emerasd Cem. - A small very carly Mclon, form globnlar, flattencd at the pore; riblerl, smonth, deer enserald greeu skill. I'kts. 5c. and 10c per $0 z$ 15c. per $1 / 4$ lb, 35c.: per lb. $\$ 1.2 .5$.

Netted Gem.-About five inches long and slightly pointed at blossom end: dev'ply ribberl and heavily ncted, fesh green and thick; cavity smull, with golren lining next secd. Pkts. 5c. and 10c.; per 0\%. 10c.; per $\frac{1}{4}$ lb 00 ; jer lb. 90c.

Acme Camtaloune - 1 Telo:

Baltimore. Known in Mar

pointed at both ends. strongly

under averno

The best selling Nelou jim the lhing

per $1 / 41 \mathrm{lb}$. 30c.; per $1 \mathrm{~b}, 90 \mathrm{c}$.

Atlantic City - A bo!d pinesple

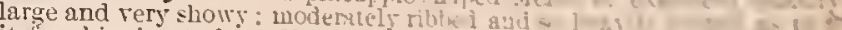

it for shipping to ling di-?

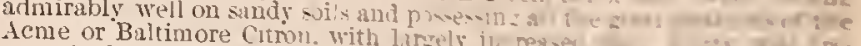

quently fill a barrel and their apreanice res ve

per oz. $15 c_{*}$; per $1 / 4 \mathrm{lb}$. $4 \mathrm{c}$.; ; per $1 \mathrm{~b}$. $: 1.50$

Golden Jenny,-Small. lut hichl

ib. $\$ 1.25$.

Extra Early Mackensack.

olu II ackousgek. Small foliswe Protita

in New Yoris and Easteru murkets. Pk

Galmon and Green.-

silightly oral and regulinly rounded

poltion extending to be vers sind

hardy; internedinte in rimenim wo wat

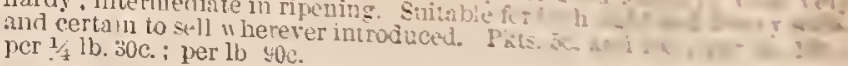




\section{- CANTALOUPE OR CITRON-CONTINUED.}

- erred Nutmers Cantaloupe.-Pkts. 5c. and 10c.; per oz. 10c.; per $1 / 4 \mathrm{lb}$ lb 30c. ; per lb. 90c.

Large Acme.-Grown by truckers on the eastern shore of Maryland and along the borders of the Chesapeakc. Twice the size of tbe old Acme and coming rapidly into demand. Pkts. 5c. and 10c.; per oz. 20c. ; per $1 / 4$ lb. $60 \mathrm{c}$; per lb. $\$ 2.00$.

Green Citron Cantalounze.-Pkts. 5c. and 10c.; per oz. 10c.; per $1 / 4$ lb. 30c.; per lb. $90 \mathrm{c}$.

Pineapple.-Of first quality. Form oblong. A standard sort. Pkts. 5c. and 10c. ; per oz. 10c. ; per $1 / 4$ lb. 30c. ; per lb. 90c.

Missouri. - A new sort of rare good quality. Form globular, flattened at each end; wonderfully ribbed, with dark greeu cavities, ribs covered with strong netting, fitting it for shipment; lesh green, flavor excellent, foliage small and hardy. Pkts. 5c. and 10c.; per 0z. 15c.; per $1 / 1 \mathrm{lb} .45 \mathrm{c}$. ; per $1 \mathrm{~b} . \$ 1.50$.

Irilier's Crearm.-Plsts. 5c. and 10c.; per oz. 10c.; per $1 / 41 \mathrm{lb} .30 \mathrm{c} . ;$ per lb. $90 \mathrm{c}$.

Osage.-A new salmon-fleshed variety favorably thought of in the Chicago and other Western markets. Pkts. 5c. and 10c. ; per oz. 10c. ; per $1 / 4 \mathrm{lb} .30 \mathrm{c}$. per lb $20 \mathrm{c}$.

Califormia citron.- - Mesh deep orange, attractive in appearance. Weight up to twelve pounds. Eighteen to twenty will fill a barrel. Suitable for heary soil. FVell netted. Pkts. 5c. and 10c.; per oz, 15c. ; per $1 / 4$ lb. $35 \mathrm{c}$. ; per lb. $\$ 1.25$.

Surprise.-A Citron of cream-colored rind, with thick salmon-colored tesh : large and early. An excellent sort. Suitable for heavy soil. Pkts. 5c. and 10c.; per oz. 10c.; per $1 / 4$ lb. 30c. ; per lb. $90 \mathrm{c}$.

Mackensack or Turk's Cap.-Flesh green; a favorite with market gardeners. One of the best Melons for shipping, will carry ten days. Twenty will generally fill a barrel. Five hundred Melons selected for our own seed weighed 2500 pounds. Suitable for heavy scil. Pkts. 5c, and 10c.; per oz, 10c.; per $1 / 4$ lb. 30c.; per lb, 90c.
Montreal.-A showy Citron, average weight ten pounds, though going up to twenty. Well ribbed and netted. Flesh deep, sugary, and green io color. Flavor fine. Suitable for heary soil. Pkts. 5c. and 10c.; per oz 10c. ; per $1 / 4$ lb. 30c.; per $1 \mathrm{~b}$. $\$ 1.00$.

Casaba (Persian).-A very showy Cantaloupe, flesh orange in color. This sort sometimes produces fruit twice as large as an ordinary Canta loupe, often the size of an ordinary Watermelon. Form oblong. Suitar ble for heavy soil. Pkts. 5c. and 10c.; per oz. 10c.; per $1 / 4 \mathrm{lb}$. $30 \mathrm{c}$. ; pez lb. $90 \mathrm{c}$.

Delmonico.-A golien-fleshed Cantaloupe of New York origin. PEts. 5c. and 10c. ; per 0z. $10 \mathrm{c}$. ; per $1 / 4 \mathrm{lb} .30 \mathrm{c}$. ; per lb. $90 \mathrm{c}$

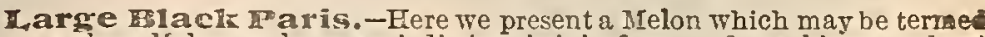
a show Melon, so large and distinet is it in form and markings, and yet it possesses qnalities of the first order. Described, it is a very large, oblong, square-ended Cantaloupe Melon, weighing from ten to fifteeu pounds. Rind black; ribs broad, massive and prominent, with deep cavities between; skin somewhat netterl; flesh deep orange, rery thick and excellent in fn vor. Foliage small, and resisting heat. Very showy and and 10c. ; per oz. $15 \mathrm{c}$.; per $1 / 4$ lb. $45 \mathrm{c}$. ; per lb. $\$ 1.50$

Reedland Giant.-A showy Cantaloupe of manumoth size, often reaching twenty-five pounds, and as large as en average-sized Watcrmelon. Flesh greeu, melting, sugary. Not suitable for light land. Pkts 5c. and 10c.; per oz. 10c. ; per $1 / 4 \mathrm{lb}$. 30e. ; per $1 \mathrm{~b} . \$ 1.00$.

Harge White French.-It is a chunkr, oblong Cantaloupe Nelon of large diameter, fruit weighillg on an average about teu pounds. The character of this Melon fits it as a show Melon, and yet it is so delicious in flavor as to make it desirable on any table. Rind whitish green, turning to yellow; ribs protruding to such an unusual degree as frequently to make the fruit prismatic; skin slightly netted; flesh yellow and orange, when ripe the edible portion extending almost to the skin. Only suitable for black or heavy soil. Plkts. c. and c.; per oz. c.; per $\%$ lb. c.; per lb, 8 .

\section{A CHOICE WATERMELON,

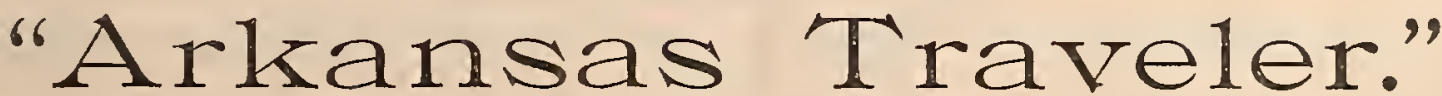

A LARGE, LONG, WEIGHTY MELON. RIND DARK GREEN, WITH WAVING STRIPES OF BLACK; INTERIOR ALWAYS SOLID, THE EDIBLE PORTION EXTENDING TO WITHIN HALF AN INCH OF THE SKIN. FLESH BRILLIANT RED, SWEET, TENDER, CRYSTALLINE, VERY JUICY AND ALTOGETHER QUITE SUPERIOR. SEEDS VERY SMALL AND DISTINCT. RIPENING AS AN INTERMEDIATE, A VERY HARD RIND, AND THEREFORE A GOOD SHIPPER.

$\rightarrow$

Lovers of good Watermelons will find in the Arkansas Traveler a most delicious and refreshing morsel, and the Southern planter who sends the firt shipment to a Northern market will be well repaid for his labor, as every Northern market for several years past has been overflooded with the Kolb Gem, the quality of which is so miserable that the desire for Watermelons has almost been destroyed, and in sections where hundreds of thousands were sold years ago the demand for chunky NIelons has fallen off to such an extent that Kolb Gems barely bring the freight, sometimes not that.

The Kolb Gem has earliness, produetiveness, and good shipping qualities, but these do not count at the Watermelon pile with the consumer; he is the one that has the Melon to eat, and there lies the proof-if the Melon is not good he will have no more of that variety, and so critieal is he that he will not even select one of the same chunky shape. There are several varieties of Long Watermelons in addition to the Arkansas Traveler which are infinitely snperior to the Kolb Gem, such as Landreths' Boss, Long Dixie, Florida Favorite, Landretns' Long Light Icing, and Ice Cream. 'The successful planter is he who studies the taste of the consumer. There is no such thing as fashion in Watermelons.

\section{INSECTICIDES.}

THE discovery of an article which, while not injuring the Cucumber plant, will restroy the bug which infests it from the time of its germination until it has attained a growth of three or four rough leaves, is a subject of the greatest iuterest to all cultivators of this fruit.

So much has been written of a eontrudictory nature upon this subject that it is next to impossible to determine what remedies to adnot. We wrould suggest that each cultivator experiment for himself with several compounds, for instance, one part of hellebore mixed with fonr parts of gromd land plaster ; one part of sing shnt mixed with six parts of land plaster; one part Paris green mixell with twelve parts of land plaster, and one pint of kerosene oil mixed

Gond results in the destruction of squash bugs have been obtained by the application, under ground swout the roots of the plants, of the liquid of carber bisulphide, the fnmes of which are quickly deadly to insect life. 


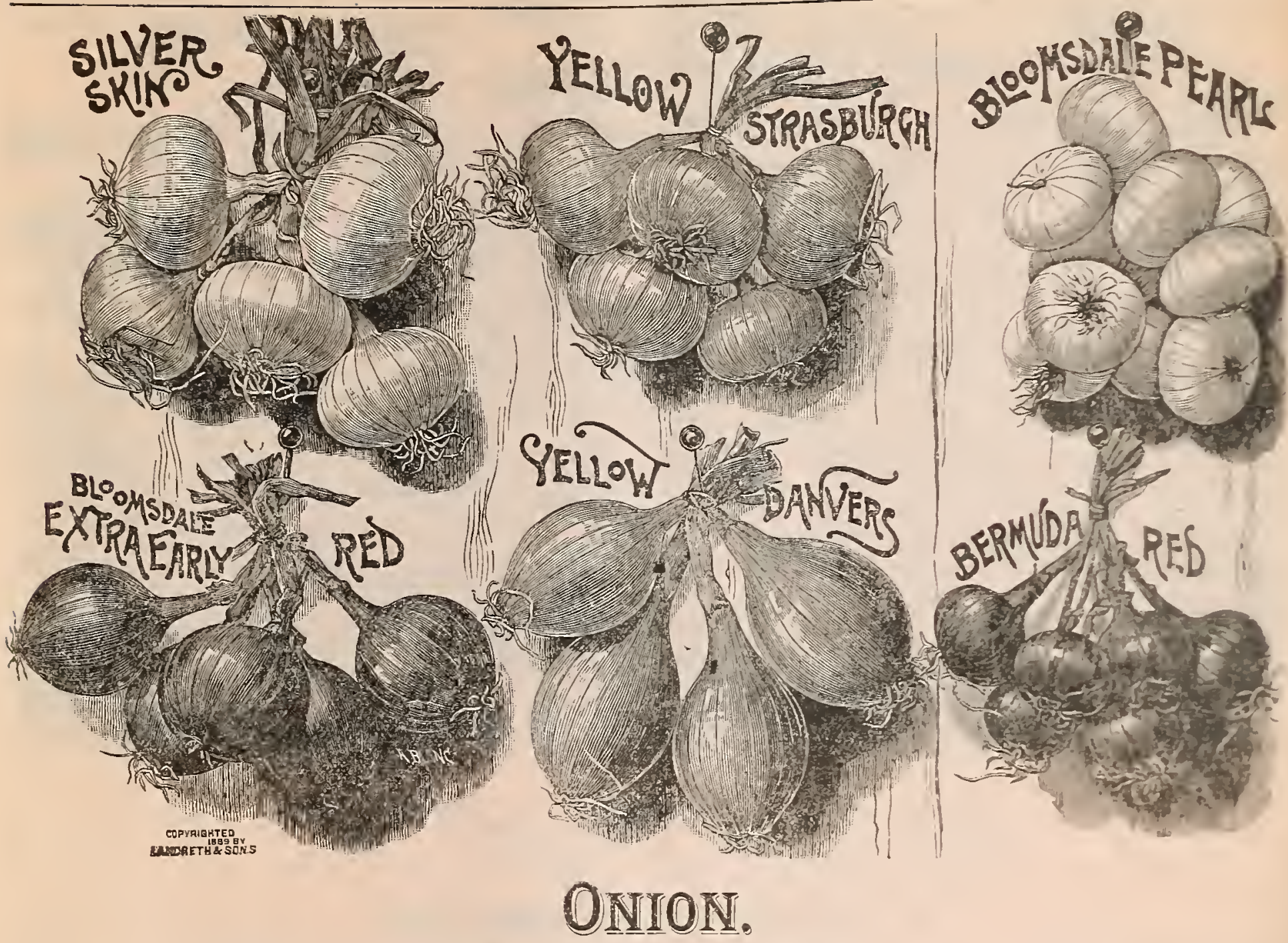

Alium cepa-Ognon-3ritebel-Cebolla-Rodlog.

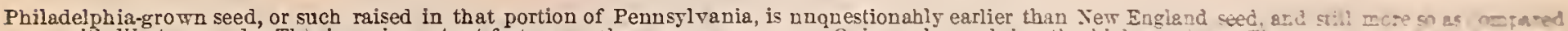

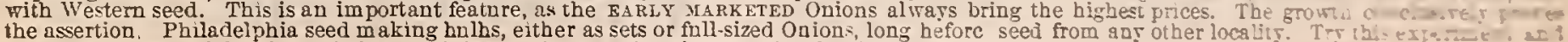
be satisfied. The yield of seed heing mnch less to the acre than in any other locality, Philadelphia stock commands a higher 1.

\section{LARGE ONIONS FPOY SEED.}

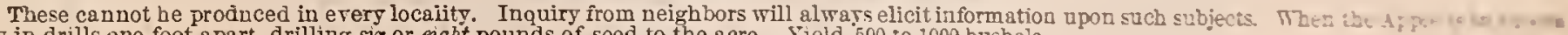
sow in drills one foot apart, drilling six or eight pounds of seed to the acre. Yield 500 to 1000 hushels.

\section{SETS FBOH SEED.}

Drill, when the Apple is in hloom, sixty to seventy-fire pounds of seed to the acre. At Midsummer, or whenerer the tope ile. anom we at bulhs, buttons or sets, as they are indifferently called, prodnced hy this process, to a dry place. In the Autumn, or ear

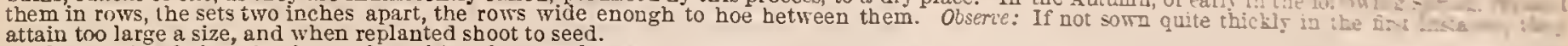

In growing Onions for the market, either from secd or sets, an unusually large size is not to be desired, two to thace inches in fiam ... the most desirahle size for shipping. A vigorously growing Onion crop frequently can he hastened to early ripeang at neg- the

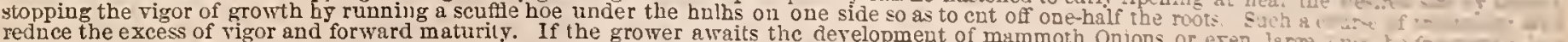
pass opportunities for paying sales, far more profitahle than afterwards realized.

NOTES ON COOKING.-No. 175.-STEWED.-Remove the coarse skin, cut in slices and put in saucepan with fresh burte- an $3:$ : light brown, add some Espagnole and a little Worcestershire sauce, salt and pepper. Cover and cook for tirentr miaute-

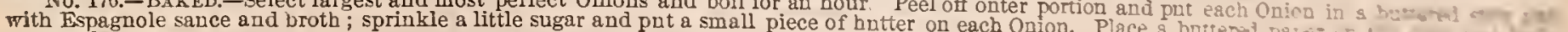
in a moderate ovell.

No, 177,-FRIED, -Wash, cnt in thin slices, dip in cream, add salt, pepper and roll in flour, fry in hot lar till crisn.

\section{CHOICE ONION SEED TO GROW LARGE BULBS.}

BIo Jmadale Autumn White Wax.-Form, more flat than the Philadelphia Silver Skin, and of ahout the same size. Color a waxy White, quite distinct from the Philadelphia Silver Skin. Maturity, ten days earlier than the Philadelphia Silver Skin. Flavor very mild. A sort which may be considered as combining the qualities of the Bloomsdale Pearl and the Philadelphia Silver Skin, and therefore a desirahle acquisition. Pkts. 5c. and 10c. ; per oz. $35 \mathrm{c}$. ; per $1 / 4 \mathrm{lh}$. 95c.; per lh. $\$ 3.50$.

\section{Extra Early Bloomsdale Pearl}

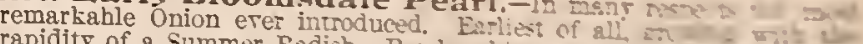
rapidity of a Summer kadish. Pearly whi:e, waxt ras

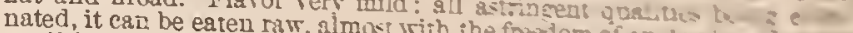

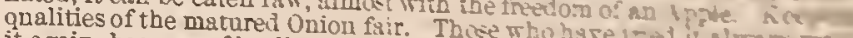

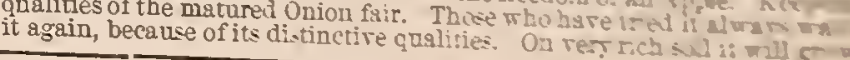




\section{CHOICE OIION SEED TO GROW LARGE BULBS.-CONTINUED.}

almost ton lalge for market, sometimes five and six inches across. Pkts. 5c. aud 10c. ; per oz. 40 c.; per $1 / 4$ lb. $\$ 1.00$; per lb. $\$ 3.75$.

Sermina Island White (TRUE STOCK).-Several days earlier in maturity than the Bermuda Island Red, and more flat, and though shipped and known as a white Onion, has an outer skin of a straw colored tone; the interior is, however, pcarly white. This seed and that of the Bermuda Island Red, we import from the Canary Islands, the source from which the Bermuda growers obtain their choice stocks. Pkts. 5c. and 10c. ; per oz. 30c.; per $1 / 4$ 1b. 75 c. ; per 1b. $\$ 2.75$.

Betrumda Island White (ITALIaN stock).-Pkts. 5c. and 10c.; per oz. $25 \mathrm{c}$.; per $2 / 4 \mathrm{lb}$. 7uc.; per lb. $\$ 2.50$.

Bermida Islawd Red (TRUE sTOCK). -Well known as among the carliest Onions appeariug in the Spring markets. Shipped from Bermuda in immense quantities. In Florida the seed is sown in October and November to very great profit for early shipment. The Sets planted in Scptember and October produce marketable Onions in early Spring. Pkts. 5 c. and 10c.; per oz. 30c.; per $1 / 4$ lb. 75 c. ; per lb. $\$ 2.75$.

Extra Early Yellow-A new and valuable sort. This onion ripens immediately after the Bloomsdale Extra Early Pearl and the Bermudas, and before the Bloomsdale Extra Early Red, aud two or three weeks before any other yellow variety. The mature onions are flat and very thin, their shape at once indicating their early maturity. Plts. 5c. and thin, their shape at once indicating their ear
$10 \mathrm{c}$.; per $0 z$. $35 \mathrm{c}$.; per $1 / 4$ lb. $95 \mathrm{c}$; per $1 \mathrm{~b}$. $\$ 3.50$.

Itallaw Queen.-An extra-early small Silver Skin. Pkts. 5c. and 10c.; per 02. 30c. ; per $1 / 4$ lb. $85 \mathrm{c}$. ; per $1 \mathrm{~b}$. $\$ 3.00$.

Ploomsdale Extra Early dorle Red.-A variety of unusually early maturity for a large red. Medium size, broad, flat, deep red in color and an excellent keeper. Several weeks earlier than the Wethersfield Red. This is a special strain difficult to obtain elsewhere. Some selections of Onion seen sold as Extra Early Red are two weeks behind the Bloomsdale in period of maturity. Plts. $5 \mathrm{c}$. and $10 \mathrm{c}$; ; per oz. $35 \mathrm{c}$.; per $1 / 41 \mathrm{~b} .95 \mathrm{c}$. ; per $1 \mathrm{~b} . \$ 3.50$.

Bloomsrale Biver Skin or White.-A mild, pleasant-fiavored variety admirable for family use, not so good a keeper as the dark-skinned varieties but better flavored and always salable. Crop very short. Pkts. $5 \mathrm{c}$. and 10c.; per $02.45 \mathrm{c}$.; per $1 / 4$ lb. $\$ 1.20$; ; per $1 \mathrm{~b}$. $\$ 4.50$.

Silver Skin.-An early white, flat Philadelphia variety. Pkts. 5c. and 10c. ; per 0z. 40 c. ; per $1 / 4 \mathrm{lb}$. $\$ 1.10$; per $1 \mathrm{~b}$. $\$ 4.0 \mathrm{v}$.

White Portugal. -Pkts. 5c. and 10c. ; per oz. 40c. ; per $1 / 4 \mathrm{lb} . \$ 1.10$; per lb. $\$ 4.00$.

Cross and Plackwell's Silver pickling.-While of the highest reputation as a rare, waxy pickle Onion, it is very desirable as an early garden sort. Pkts. $5 \mathrm{c}$. and $10 \mathrm{c}$. ; per $02.35 \mathrm{c}$. ; per $1 / 4 \mathrm{lb}$. $95 \mathrm{c}$. ; per 1b. $\$ 3.50$.

B100msdale Iarge Yellow Stragburg.-A reliable widely cultivated variety, not so strong in flavor as the Red. (rop short. Pkts. $5 \mathrm{c}$. and $10 \mathrm{c}$; ; per oz, $30 \mathrm{c}$; per $1 / 4$ lb. $85 \mathrm{c}$.; per 1b. $\$ 3.00$.
Yel10w Dutch. -A flat yellow variety. Pkts. 5c. and $10 \mathrm{c} . ;$ per oz. $25 \mathrm{c}$. ; per $1 / 4$ lb. $65 \mathrm{c}$.; per lb. $\$ 2.25$.

Giant Hed Gargautus. - A monstrous red-skinned, globular Italian Onion, known in some scctions as Poma peir. Pkts. $5 \mathrm{c}$ and $10 \mathrm{c}$.; per oz. 30c.; per $1 / 4$ lb. T5e.; per 1b. $\$ 2.75$.

Giant Erite Garganus.-Also known as Silver iring; a giant Italian variety. Hkts. 5c. and 10c.; per 0z. $30 \mathrm{c}$. ; per $1 / 4$ lb. $85 \mathrm{c}$.; per lb. $\$ 3.00$.

B 100 Ins a le Danvers Onion.-Maturing in 84 days. This seed is grown in a location removed from other Union crops and from selected bulbs the product of XXX seed stock. This strain will produce narketalle buibs in twelve weeks from date of sowing Growers of Onions for the market will at once appreciate the im portance of securing Onions for the market will at once appreciate the importance of securing seed on hand is limited, and in order to secure seed, orders should be seed on hand is limited, and in order to secure seed, orders should bo
placed early. None genuine exrept in our sealed packages. Pkts. 5c. and 10c. ; per oz. 35c. ; per $1 / 4$ lb. $90 \mathrm{c}$; ; per $1 \mathrm{~b}$. $\$ 3.25$.

Iarge Yellow G1obe Danvers.-An oval-shaped, straw-colored long-keeping variety. Superior to the Flat Yellow Dutch, the seed of which latter, a cheap variety, is often deceptively sold for it. Pkts. 5c. and 10c.; per oz. $25 \mathrm{c}$.; per $1 / 4$ lb. $65 \mathrm{c}$.; per $1 \mathrm{~b}$. $\$ 2.25$.

Yellow Flat Daryers,-A flat form of good keeping. Pkts. 5c. and $10 \mathrm{c}$; per oz. 25c.; per $1 / 4 \mathrm{lb}$. $65 \mathrm{c}$.; per lb. $\$ 2.25$.

White Kocca.-A white-skinned variety producing large balbs, round to oval in shape. Pkts. 5c. and 10c.; per oz. $30 \mathrm{c}$.; per $1 / 4 \mathrm{lb}$. $85 \mathrm{c}$.; per $1 \mathrm{~b}$. $\$ 3.00$.

Red IR occa.-On congcnial soils producing a large solid oval bulb of red skin. Pkts. 5c. and 10c.; per oz. 30c.; per $1 / 4$ lb. $85 \mathrm{c}$.; per lb. $\$ 3.00$.

Yellow Strasiburg.-A flat yellow Onion of early habit Pkts. $5 c$. and $10 \mathrm{c}$.; per oz. $25 \mathrm{c}$.; per $1 / 4$ lb. $65 \mathrm{c}$.; per lb. $\$ 2.25$.

Wethersfield I,arge red.-Be not deceived in Wethersfleld, there are many types; some selections ripen in August, others in September,
others as late as October. We need not say the variation in time makes a difference in price of product. That which we offer is the early form, twice the value of the later. Pkts. 5c. and 10c.; per oz. 25c.; per $1 / 4 \mathrm{lb}$. $65 \mathrm{c}$.; per lb. $\$ 225$.

E1 Paso (MExicaN).-A silvery white, flat sort, growing to a weight of two pounds under irrigation. Pkts. 5c. and 10c. ; per oz. $65 \mathrm{c}$; per $1 / 4$ 1b. 81.70 ; per $1 \mathrm{~b} . \$ 6.50$.

Southport IRed Globe.-A very desirable round red variety, heavy. a large producer, and a good shipper. Very salable in market. Pkts. $5 c$ and 10c.; per oz. $25 \mathrm{c}$; per $1 / 4$ lb. $70 \mathrm{c}$; p per lb. $\$ 2.50$.

Southport Yellow Globe. - A favorite yellow globe variety in the markets of New York and Boston. Solid and a good keeper. Pkts. 5c. and $10 \mathrm{c}$; per 02. $25 \mathrm{c}$.; per $1 / 4 \mathrm{lb}$. 70c.; per lb. $\$ 2.50$.

Sonthport White GIobe.-A showy large white variety. Plst. $5 \mathrm{c}$ and 10c.; per oz. $35 \mathrm{c}$; per $1 / 4 \mathrm{lb}$. 95c.; per lb. $\$ 3.50$.

\section{SEED FOR SETS.}

\section{Producing best SETS if sown thickly, also largest bulbs if sown thinly.}

B10ornsdale Silver Skin or White.-A mild pleasant-fiavored variety, admirable for family use, not so good a keeper as the darkskinned varieties, but better flavored and always salable. Very superior to the White Portugal, which is sometimes sold for Silver Skin Pkts. $5 \mathrm{c}$ and 10c.; per 02. $45 \mathrm{c}$.; per $1 / 4$ lb. $\$ 1.20$; per lb. $\$ 4.50$.
F100msdale Taro Yellow Stragburo. - A reliable and widely cultivated variety, not so strong in flavor as the Red; \& good
keeper, valuable for shipping. Pkts. 5c. and 10c.; per, oz. 30c.; per $1 / 4$ Ib. 85 c.; per lb. $\$ 3.00$.

\section{DIRECTIONS FOR SOWING SEEDS.}

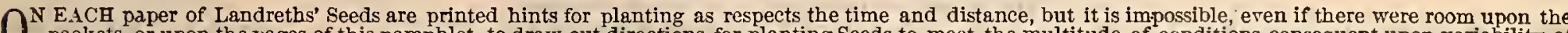

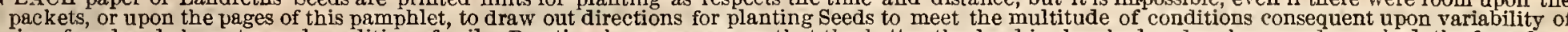

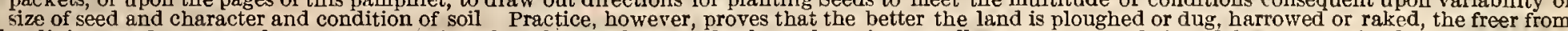

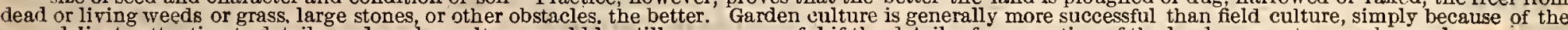
more delicate attention to details, and garden culture would be still more successful if the details of preparation of the land were yet more observed.

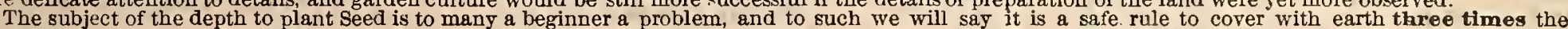

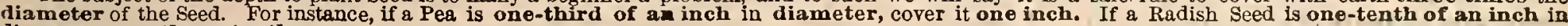
diameter, cover three-tenths. 


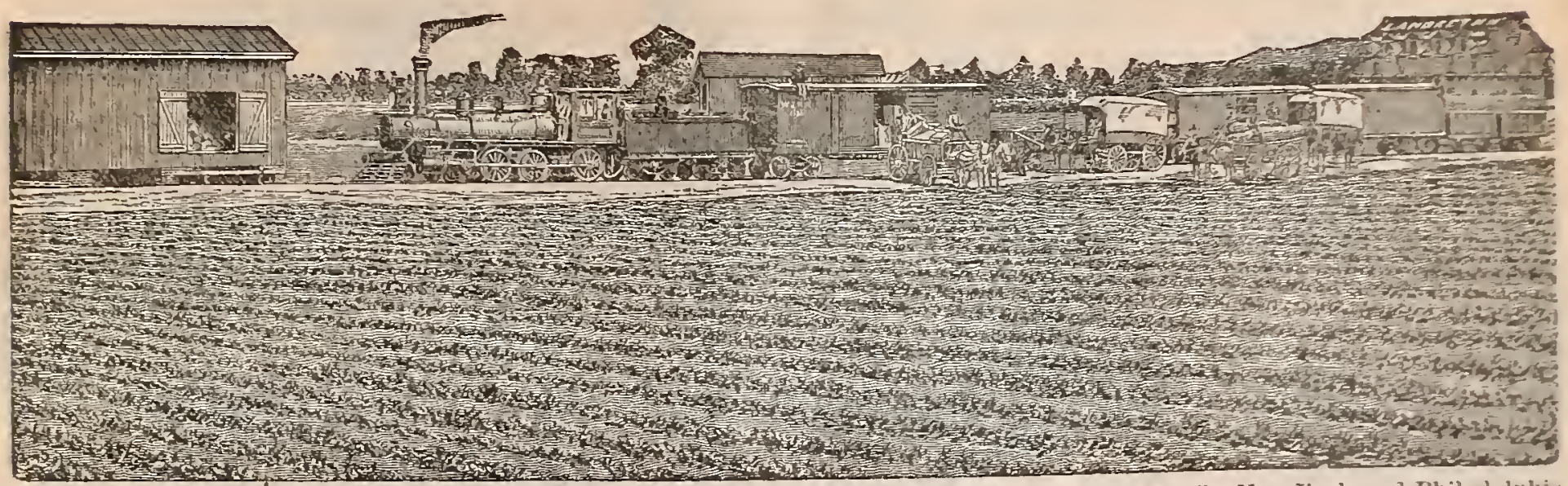

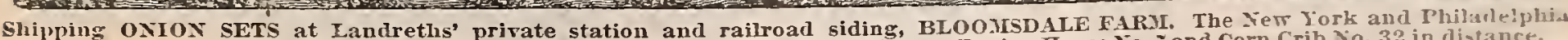

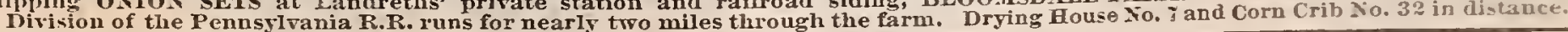

PRICEs, aay of publieation

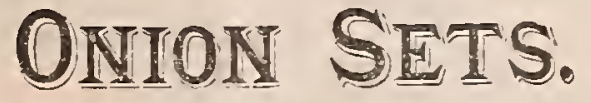

Purchasers desiring Onion me in mn-
siderable quantily, are recommonded to
write for frewh prices, which way be
lower or higher than these. of this Catalogue.

THREE QUARTS OF SEED TO 100 YARDS OF ROW. TEN BUSHELS TO THE ACRE.

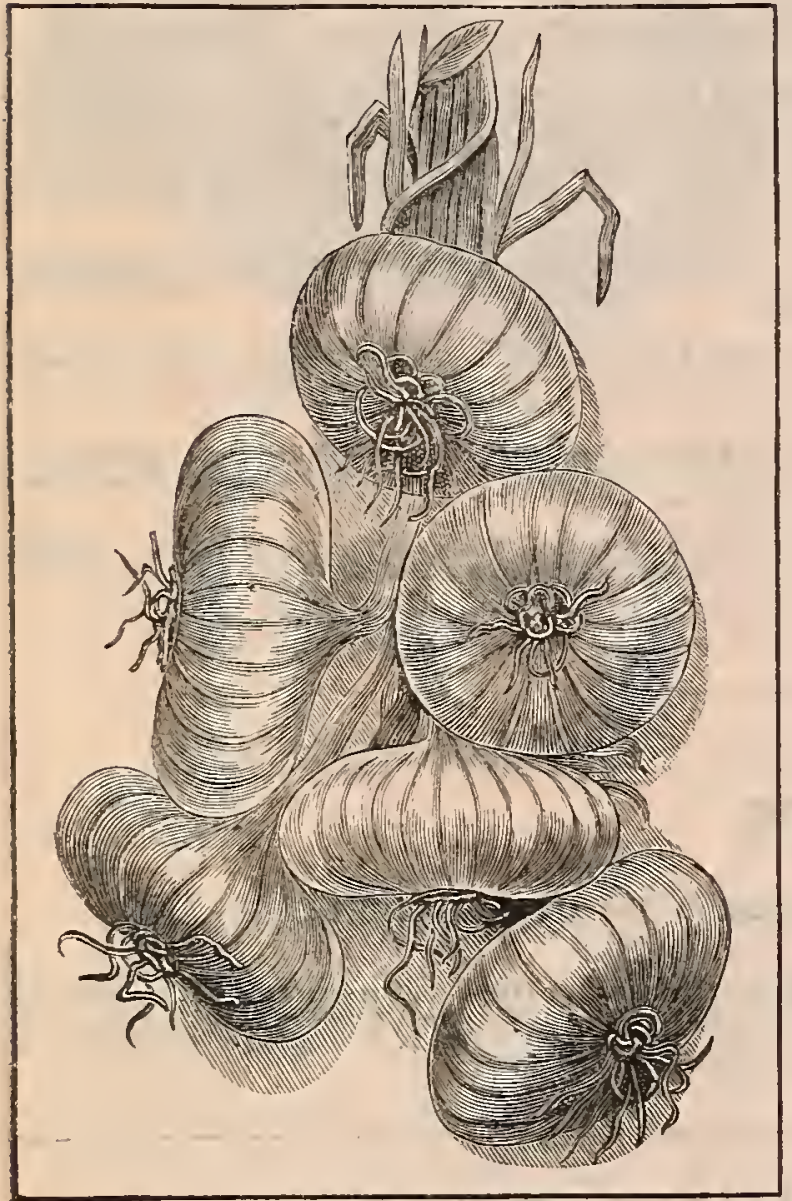

BLOOMSDALE AUTUMN WHITE WAX.

The growth of Orion Sets has for nearly a century been with us a sfeciait. Ph . sets are everywhere recognized as the best in form and in keeting quslitie i . . brighter, and in every respect better ripened than those etorn elvellow

LARGIE ONIOKS FROM SETS.-In all locatitie suth if the $\cdots:$ d of $\mathrm{Ce}$ tral Virginia or Central Kentucky we recommend that Opion sets $f$ bs ise th a

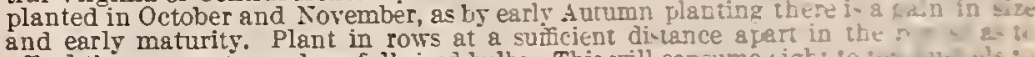
afford them room to produce full-sized bulbs. This will consume tighi to it us als : the acre. Omions produced br this system can be placed in market l to to to the

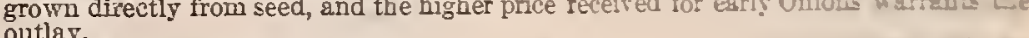
outlay. shipment from August 15th:

\section{LENDRETHS' SPECIALTIES.}

Extra Early Bloomsdale Pearl Sets.-The mast remarka introduced. Earticst of all Pearly while, iranswecht and waxt. En wase wh the

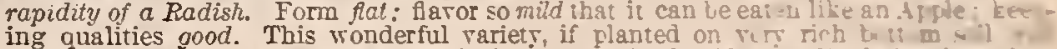
grow too large for market-five to six inches atoss. It should s coordingly be plauted or thin soil.

Note-Bloomsdale Pearl Sets, as rell as Bermuda Sets, io fully derel p thei- we wa

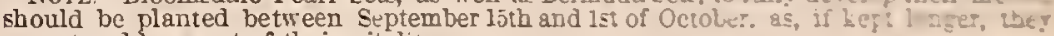
sprout and lose part of their ritality.

We only gruw Pearl Sets on contract made before 15th of March of each sea and fo: shipment Ist of September. We are readr to register orders for crop of 1 ". of one bushe? or more at any time from the present until 15th of March, 14.3. Conaract frice 5 w pe:

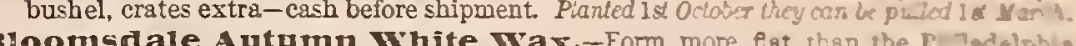

Bloomsdale Autumn White Wax.-Form more elat than the $\mathrm{P}$. Iadelyh a Silver skin, and of about the same size color a wasy $\pi$ hite quile distinct st sa lbe Flavor ver mild. A sort which may be considend as combining the oum in of ibe Bloomsdale Pearl and the Philadelphia Silver Skin, and therefore a desiab.e acomara Per qt. 30c. ; per bush. $\$ 6.00$.

White Bermuda (ExTrA EARLY).-Earlier in maturit than the Be-won fied and more flat. Per qt. $30 \mathrm{c}$; ; per bush. $\$ 6.00$.

Rea Bermuda.-Nore red than the strain sold br os last year. Lese: san more showy. Per qt. 30c.; per bush. $\$ 6.00$.

R10omsdale Fxtra Early Iellow,-Taluable sor. This rer choice $n$. ripens immediately after the Pearl and Bermudo, and before the Erisa Eats Reat and

Bloomsdale Extra Early Dark Blood Red (speculn)-i rar ot unusually early maturity , flat, medium size, deep red in color and as excel is texps.

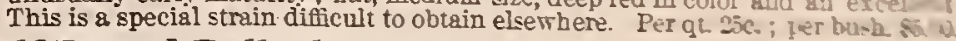

Half Round Bullock Blood.-A hand, solid, crisp, long.zeeping sor $F$

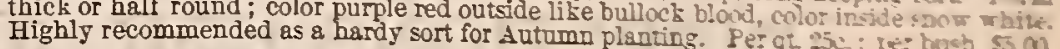
WELL-KNOWN VARIETIES.

PRICES, day of publication of this Catalogue.

Dark Red Wetherstield (SPECIALTY) . per qt. 25c.; per busb. $\$ 5.00$

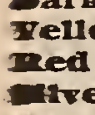

Ter

trer Skin . . . . . . . .

Banters Yellots (SPECIALTY) .....

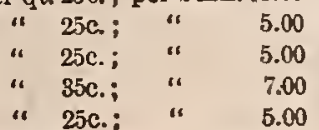

Yellow Strasburg.

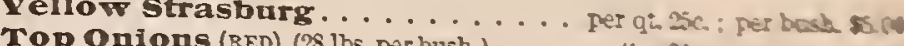

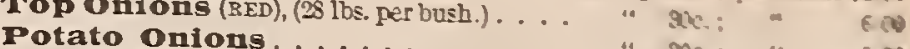

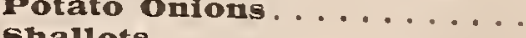
5.00

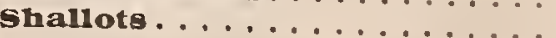

sk: : -
sce:
Sc. 


\section{MUSHROOM SPAWN (ІмтовтEр).}

Agaricus Campertris-Champignon comestible-Champignonbxut-Seta-Kampernoelic.

The culture of Mushrooms to the initiated is very easy, but it is a subject of much difficulty to the novice. We cannot attempt here to give at length the necessary directions, but refer the inquirer to some of the various publications upon the subject.

quirer to some of the various publications upon the subject.
Plant one pound of spawn to the square foot. Kept on sale in the form of Bricks. The spawn is planted in dark pits, caves, in outdoor hotbeds, or on banks of compost. Per $1 \mathrm{~b}$. 10c.

NO'TES ON COOIKING.-No. 151.-STEWED.-Wash thoroughly, peel and cut off injured parts. Ilace in porcelain stewing pan with salt, pepper and butter, and two teaspoonsful of salt water, stew for eight minutes. Serve on toast.

No. 152,-BAKED.-Clean thoronghly, remove the stems and fill the eavities with. stuffing composed of onion, tomato, parsley, chopped very fine. Add salt and pepper, put in a sauce pan with butter, stew for twenty minutes. Add crumbs of oread and thicken, fill the patties and spread crumbs upon the top. Bake in a moderato sven of few minutes and serve with brown sauce.

\section{IUSTARD.}

Sinapis alba and S. nigre-Moutardi-Sent-Mootaro-Mostads?

FIVE OUNCES OP BEED TO 100 YARDS OF ROW. FOUR POUNDS TO THE ACRE.

Sicw early in the 9pring in rows one foot apert. To heve a successlon the sowings should be made every two or three weeks till October. Cut young; when old the flevor is strong. Once sopn in the garden it is pretty certain to perpetuate itself.

Floomgdale Iarge-I,eaved (EARLY).-So named by reason of producing leaves when fully developed as long and brosd as the largest Tobacco. The leaves when small are very tender, and admirable ss \& salad. Pkts. 5c. and 10c.; per 0z. 10c.; per 1/4 lb. 30a.; per 1b. 31.00 .

Creole ( $A A R Y$ ). - A fine curled sort. It is quite ornamental in sppearsnco. Płts. 5c. and 10c.; per 0z. 10c.; per $1 / 4$ lb. $30 \mathrm{c}$; ; per $1 \mathrm{~b} .81 .00$.

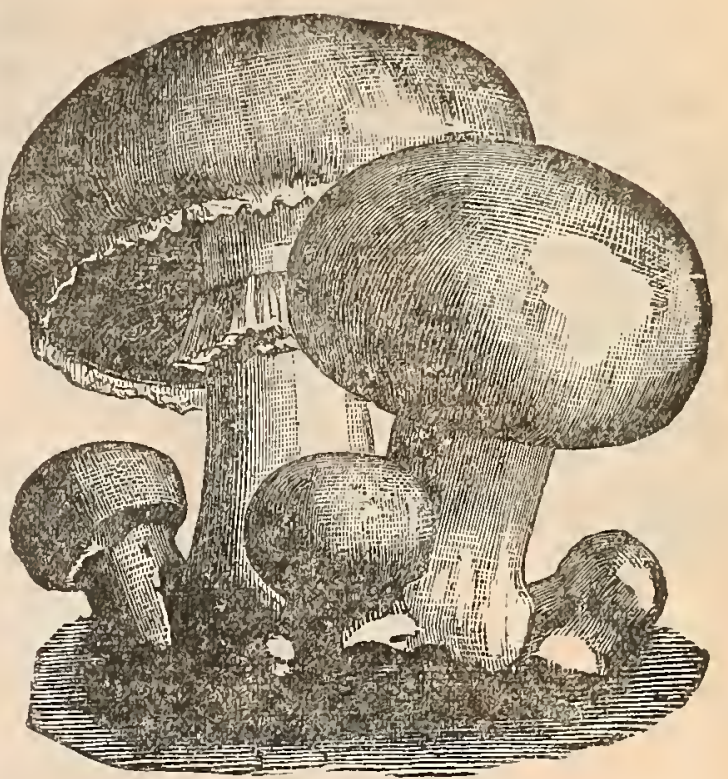

Finde.-Plts. 5c. and 10c.; per oz, 10c; per 1/1 lb, 10c.; per Ib. 30c.

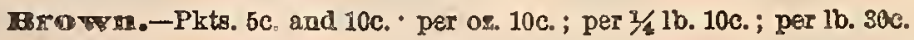

Giant southern Curled.-Plts. 5c. and 10c.; per os. 100.; per y the 30c.; per lb. 90c.

\section{NASTURTIUM, OR INDIÂN CRESS.}

Tropsolum majus-Capucine grande-Capuchina grande-Sapuzıner ober İnbifdes-Areffe-Capucine-Kere.

FOUR OUNCES OF SEED TO 100 YAFIS OF ROW.

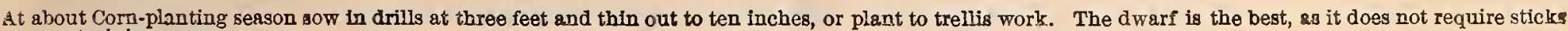
nor training.

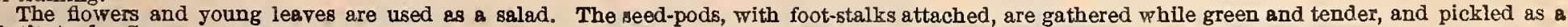
substitute for Capers.

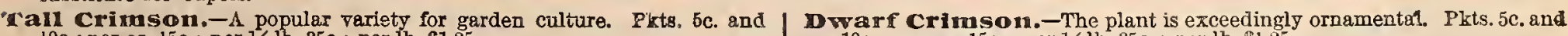
$10 \mathrm{c}$; per oz. 15c.; per $1 \frac{1}{4} 1 \mathrm{~b}$. $35 \mathrm{c}$; per lb. $\$ 1.25$. 10c. ; per oz. 15 c. ; per $1 / 4$ lb. 35 c. ; per $1 b . \$ 1.25$.

\section{AN ESTIMATE OF SEED AND NUMBER OF PLANTS REQUUISITE TO GROP AN ACRE IN ANY ONE VARIETY.}

It will be noticed that these quantities are in some instances in excess of what will be actually required, but are given to insure a full stand; it is poor economy to stint the quantity of seed.

Asparagus in 12.inch drills . . . . . 16 quarts.

Barley plants@4x1/2 ft . .

Beans, Bush, in drilis @2 $21 / 2 \mathrm{ft} . \therefore \therefore 11 / 2$ bushels

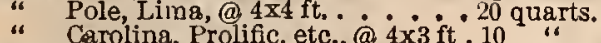

Beets and Mangolds in drills @ $2 \frac{1}{2} \mathrm{ft} . .12$ pounds.

Broom Corn in drills
Cabbage sown in outdoor beds for trans-

planting . ...... 10 ounces.

Cabbage sown in frames... .24

Carrot, in drills@21/2 ft. . . . ....3 pounds

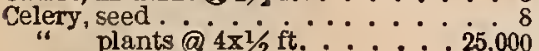

Clover, white Duîch. . . . 25,000

" Luccrne. . . . . . . . 12 pound

. Alsike . . . . .

“ Large Red with Timothy ... 12 "

Corn, sugar............. . 9 quarts.

Corn Salad, in drilis $@ 10$ inches, large

geed. ..... ...25 pounds.
Cucumber, in hills @ $3 \times 4 \mathrm{ft} . . . . .2$ quarts.

Egg Plant, plants $3 \times 2$ ft. . $\ldots \ldots \ldots 3$ ounces.

Endive in drills @ $21 / 2 \mathrm{ft} . . . \ldots \ldots 3$ pounds

Flax, broadcast.

Grass, Timothy with clover . . . . 6 quarts

" Orchard without " $\ldots \ldots .10$ "

" Orchard. .

" Red Top, or Herds. ......20 "

" Rye...........

Hemp hroadcrst $\ldots \ldots \ldots . . .32$ quarts.

Kale, German Greens. $\ldots \ldots$ sounds.

Lettuce, in rows $@ 2{ }^{\prime} \mathrm{ft} . \ldots \ldots . .3$

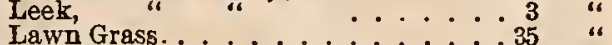

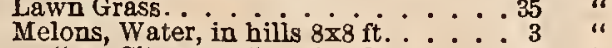

" Citron, " $4 \mathrm{x}+\mathrm{ft} \ldots \ldots \ldots 2$ ".

Oats. id drills, $21 / 2 \times 1 / 4$ ft $\ldots \ldots \ldots 20$ pounds

Onion, in beds for sets $\ldots . . .60$ " in rows to make large bulbs. $: 60$
Parsnip, in drills @21/2 ft . . . . . 5 pounds.

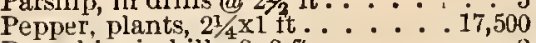

Punpkin in hills, $8 \times 8 \mathrm{ft} . \ldots \ldots 2$ quarts.

Peas, in drills, short varieties. . . "i " tall ". .1 to $1 / 2$ "

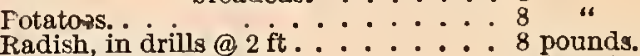
Radish, in drills @2 ft........8 8 pounds.

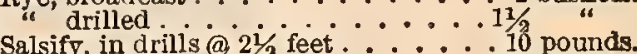
Spinach, broadcast . Squash, Bush, in hills, $4 \times 4 \mathrm{ft} . . . .3$ Sorghum ming, " $8 \times 8 \mathrm{ft} \ldots \ldots .2$ quarts.

Turnips, in drills $@ 2$ ft. . . . Turnips, in drills ${ }_{\text {broad cast. }} \mathrm{ft} . \ldots \ldots \ldots 2^{1} \mathrm{y} / 2$ pound

Tomatoes, in frame $\ldots \ldots \ldots$ ounces. " seed in hilis $3 \times 3 . \ldots 3800$

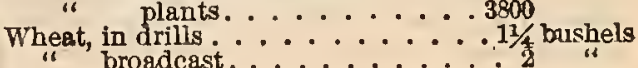




\section{OK蛋瓜。}

Hïiscus esculentus-Gombaud-Dder ober Bombo-Gombo-Quimbombo.

TWELVE OUNCES OF SEED TO 100 YARDS OF ROW. TWENTY POUNDS TO THE ACRE.

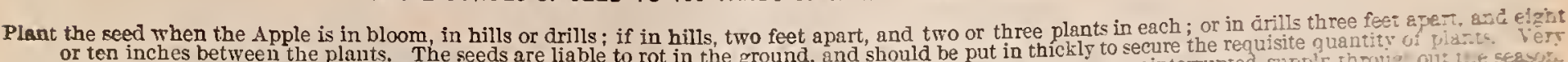

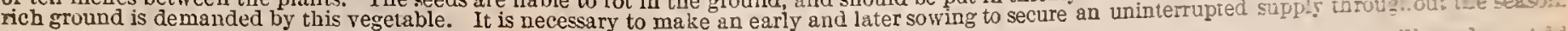

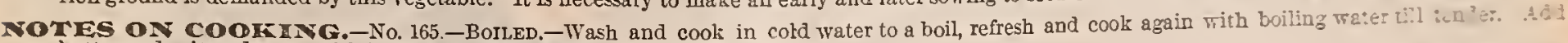

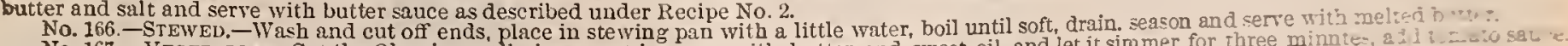

No. 167. - VEG ET - - Cut the okra in small pin salt, pepper and small pieces of butter. Or $\rightarrow$.

No. 168. - Soup. - The Olira for soup must be tender, which condition can only be found when the pods are small. To jreyare ntaras

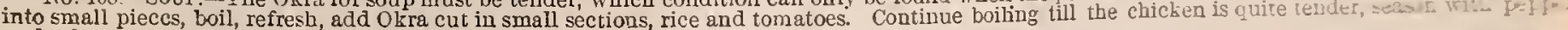
and salt.

New South.-A new dwarf variety, an acquisition. Pods long, very slim, cylindrical, green, smooth, rery choice. Pkts. 5c. and 10c.; per oz $10 c$; per $1 / 4$ lb. 30c.; per $1 \mathrm{~b}$. $\$ 1.00$.

Dwarf.-Feight three feet. Plts. 5c. and 10c.; per oz. 10c.; per $1 / 1 \mathrm{lb}$. 25c. ; per 1b. $75 \mathrm{c}$.

Prolific.-Height four feet. Very prolific in long, smooth and sim pods. Pkts. 5c. and 10c.; per oz. 10c.; jer $1 / 4$ lb. $25 \mathrm{c}$. ; per 1 b. 75 c.

Landreths' I,ong Green Pod.unusual length, often ten inches lop, when math intensely green color. The best of all green sorts art ras : if I $W_{i+}$ : use in large quantities. No other sort can compre wi 1 :..... P\&L. and 10c.; per 02. 10c, ; per $1 / 41 \mathrm{~b} .25 \mathrm{c}$. : per $1 \mathrm{~b} .75 \mathrm{c}$.

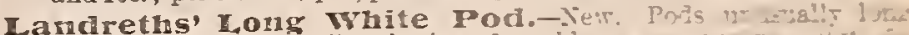

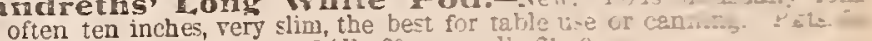

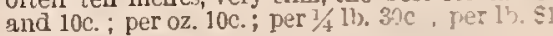

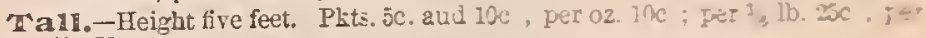
1b. $75 \mathrm{c}$.

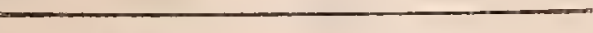 \\ PARSLEY. \\ Apium peiroselinum-Persih-\$peterfilti-Perejü-Petersije.}

TWO OUNCES OF SEED TO 100 YARDS OF ROW. EIGHT POUNDS TO THE ACKE.

The drilling should take place when the Cherry is in bloom, and may be continued until eariy Autumn.

If for horse culture, the rows should be three feet apart; if for hand culture, the rows should be eighteen inches apartw

Bingle.-Pkts. 5c. and10c.; per oz. 10c.; per $1 / 41 \mathrm{~b}$. 20c.; per 1b. $60 \mathrm{c}$.

Fine curled.-Plsts, 5c. and 10c.; per oz. 10c.; per 1/41b. 25c.; per lb. 75c.

Moss Curled. - Extra fine in appearance. A shy seeder and therefore high in price. Pkts. 5c. and 10c.; per oz. 10c.; per $1 / 4$ lb. 30c.; per lb. $90 \mathrm{c}$.

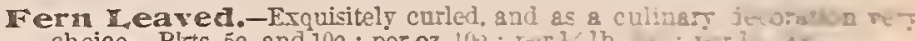

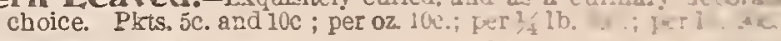

Eu erald,-Very superior, Tery fine curled an color. A well-bred rerr choice strain, short jointel mifiod cemst

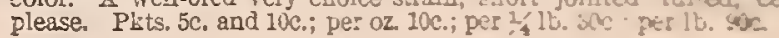

\section{PARSNIP.}

Pastinaca sativa-Panais-Chinivia-Baptinale-Pastinas.

THREE CUNCES OF SEED TO 100 YARDS OF ROW. EIGHT POUNDS TO THE ACRE.

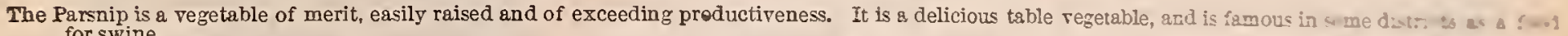
for swine.

When the Peach is in blossom, sow in shallow drills in good groun
inches, thin them to stand four inches asunder. Yield 300 to 700 bushels.

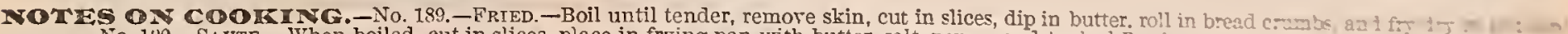
No. 190.-SAUTE. - When boiled, cut in slices, place in frying pan with butter, salt, pepper and hashed Parsler.

Thrmip-Rooted.-This variety has a root the form of a flat or round Turnip. Earlier than the long forms, and therefore desirable for early use. Especially adapted to shallow soils, hard clays or gravels, by reason of its surface development. Pkts. 5c. and 10c.; per oz. 10c.; per $1 / 4 \mathrm{lb}$. $25 \mathrm{c}$.; per 1 b. $75 \mathrm{c}$.

Bloomsdale.-The Bloomsdale is the best bred and handsomest Parsnip to be found-it is a new form, half long, wedge shaped, hollow crowned and rery broad at the shonlder, essily isten ca? : the 5.
ducing more tons to the acre than the lonser an i

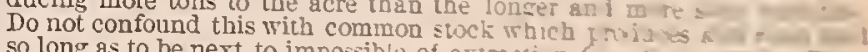

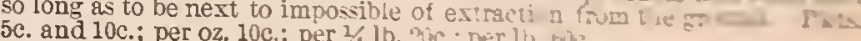

Surar crover

and loc.; per oz $10 \mathrm{c}$.

\section{A FAMOUS WINTER CABBAGE. Bloomsdale Late Flat Dutch.}

THE STOCK OF THIS FAMOUS CABBAGE WAS ORIGINALLY OBTAINED FROM THE GERMAN AND SWEDISH MARKET GARDENERS WHO HAD SETTLED IN PHILADELPHIA ANTERIOR TO THE REVOLUTION.....

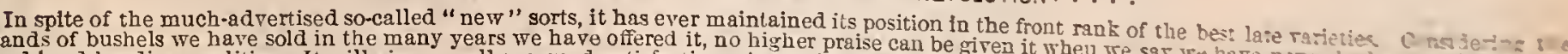
true and hard-heading qualities. It will give equally as good satisfaction when sold under the gimes of " sure sar we hsve nerer bild a comple.

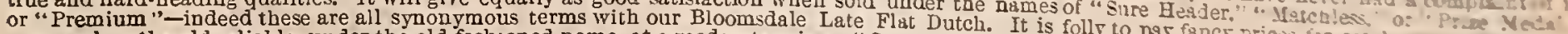
you can buy the old reliable, under the old-fashoned name, at a moderate price "Grown on our own farms" pas fancr prices to: casch-peanr 2 ites whe 


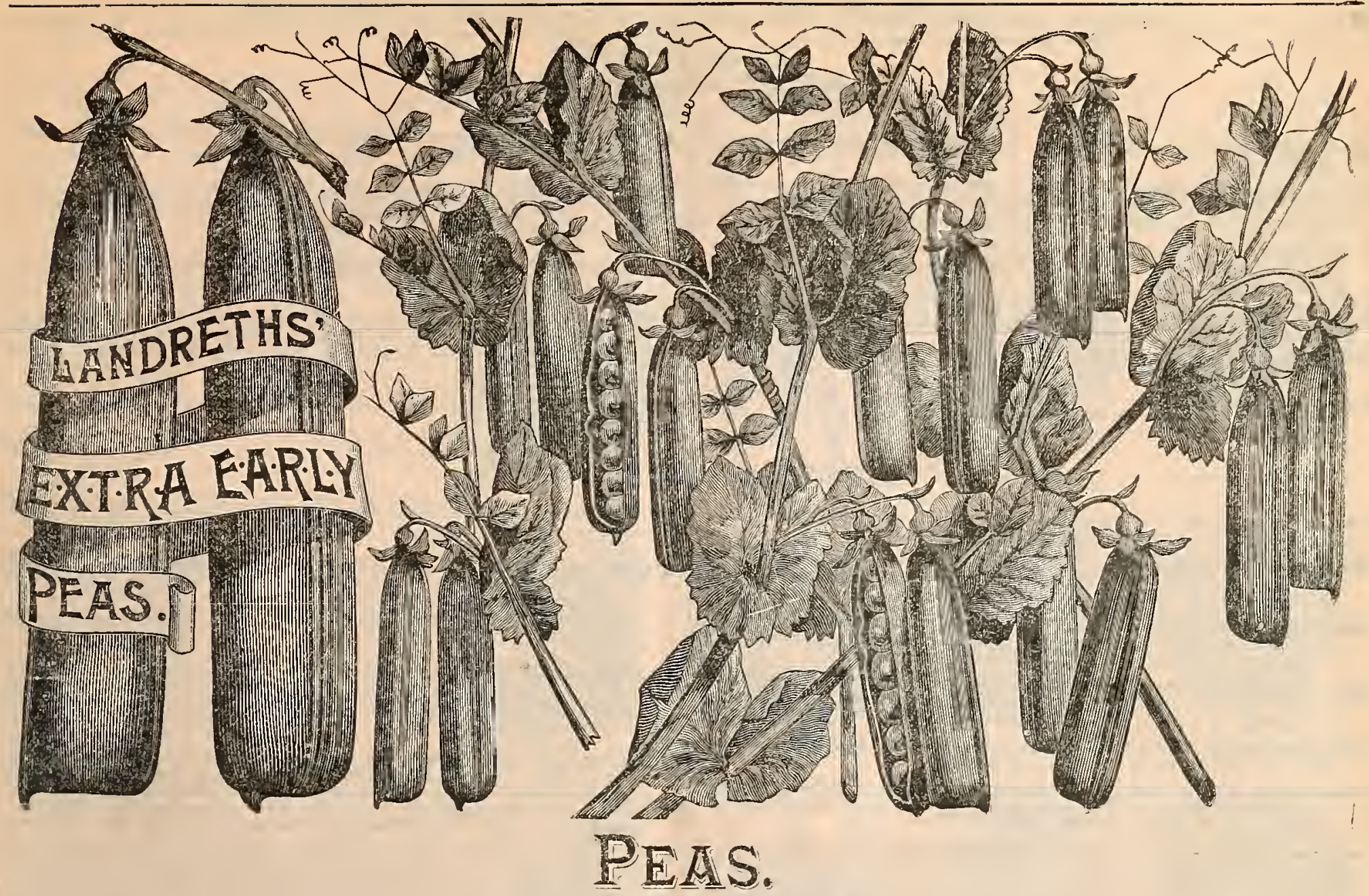

Fisum sativum-Pois-Guisante-Cribjert-Havezrl.

THREE QUARTS OF SEED TO 100 YARDS OF ROW. TWO BUSHELS TO THE ACRE.

Peas are among the first seeds that may be sown at close of Winter, frequently being planted before sharp frosts are fully over. The drilling of Peas may be safely coinuenced when the Peach is in bloom and contiuned at intervals up to within sixty days of frost for the early kinds or seventy days for the inter commenced subject to mildew. Landreths' Exira Early will be found to be the best for Angust and September sowings because of its early ripening habit and its ability to resist mildew. The dwarf varieties mas be drilled at two feet if cultivated by horse power, or fifteen inches if to be hoed by hand. The varieties of medium leugth should be drilled not closer than three feet and the tall-growing sorts at five feet apart. The number of Peas in a row may vary from ten to the foot in the case of the very dwarf kinds, to eight to the foot of the medium tall varieties, and six to the foot of the very tall kinds. Yield 100 to 300 bushels. At Philadelphia the highest average price paid by commission merchants for Early Peas is from $\$ 3.00$ to $\$ 1.00$ per bushel, and the highest price paid for late varieties is $\$ 1.50$ to $\$ 2.00$ per bushel, while the price sometimes is as low as 50 to 80 cents per bushel. Early Peas are not grown profitably at less than 80 cents per bushel, nor late Peas at less thau 60 cents per bushel. The Pea thriwes best in light, loamy soil ; the early and dwarf sorts demaud rich ground.

\section{Landreths' Gelebrated Extra Early Peas,}

Introduced by us in 1823, are put up in Red Cloth Bags (wired and lead-sealed) with our Bell Trade-mark, of one bushel, balves, quarters and eighths-no extra charge for bags-and in Sealed Cardboard Packages of one pints and one-third pints, and in Flat Packets. We will sel them in this form alone, introduced by us in the Autumn of 1878 , to check the enormous frauds practiced by irresponsihle parties, who alike injured the conscientious merchant the consumer, and ourselves by knowledge and of doubtful quality at best. Purchasers of Landreths' Sealed Red Bags can plant the contents with confdedce, and rest satisfied to knowledge and of doubtful quality at best. Purchasers of Landreths' Sealed Red Bags can
abide the result.

\section{EARLIEST SORTS.}

Landreths' Extra Early Pea (REgISTERED).-Every seedsman | ] 'o. 4284. has what he claims to be the best Extra Early Pea in existence. Now it cannot be possible for every dealer to have the best, as the Pea-growing fields are scattered over a thousand distinct soils and the crops developed under a wide range of climatic influeuces from Pennsylvania to Vermont and from New Jersey to Ninnesota. Certainly, Peas grown under such and from New Jersey to Minnesota. Certainly, Peas grown under such varying conditions must change in height, maturity and productiveness as much as does wheat, barley, or oats grown over such an extended range
of country. Landreths' Extra Early Peas are of the origiual stock named and introduced seventy years ago-the same always, the gilt-edge No. 1 grade to which all other seedsmen strive to attain. Sometimes they do, but far oftener fail. It is safe not to make any experiments in sorving a Pea which requires seven weeks of culture to prove its merits; better stick to a certainty. Pkts. 5c. and 10c. ; per qt. 30c. ; per 1/4 bush. $\$ 1.60$; per bush. $\$ 6.00$.

A1pha.-Ripens with Extra Early. Pkts. 5c. and 10c.; per qt. 25c.; per 1/4 bush. $\$ 1.20$; per bush. $\$ 4.50$.

Sitka.-Identical with Alaska, a green-seeded Extra Early Pea. Pkts. 5c. and 10c.; per qt. $25 \mathrm{c}$; ; per $1 / 4$ bush. $\$ 1.40$; per bush. $\$ 5.00$.

UNITED STATES OF AMERICA. PATENT OFFICE.

To wIT: Be it Remembered, That on the seventh day of November Anmo Domini 1881, Oliver Landreth, of Philadelphia, Pennsylyania, deposited in this office for registration a Label, of which the following is the title:

\section{" LANDRETHS' EXTRA EARLY PEAS."}

The right whereof he claims as sole proprietor in conformity with the lave The right whereof he claims as sole proprietor, in conformity with the law Trade-marks and Copyrights," approved June 18.1874.

Trade-marks and Copyrights," approred June 18. 1874 . I.S. of Patents to be hereunto affixed this ninth day of December, 1884 . ninth.

Given under my hand at Washington, D. C. The foregoing is a copy of the record, and attached hereto is a copv of said Label.

BENJ. BLTTERWORTE 


\section{PEAS-CONTINUED.}

axentis Invicta.-Pkts. 5c. and 10c.; per qt. 25c.; per $1 / 4$ bush. $\$ 1.20$ : yer busk. \&..50.

Q Gruerican Wonder.-Vine six to eight inches high and very prolific in pals of strikiug form and size. In maturity it is among the first earlies. Phts 5e. ard 10e; pcr qt. $35 \mathrm{c}$.; per $1 / 4$ bush. $\$ 1.10$; per bush. $\$ 6.50$.

Tom Tinumb.-This productive rariety was introduced and named by us in 1850 ; vine busly, growing to a height of five to eight inches. Pkts. $5 \mathrm{c}-2 n \varepsilon 10 \mathrm{c}$; ; per qt. $25 \mathrm{c}$; p per $1 / 4$ bush. $\$ 1.40$; per bush. $\$ \overline{5} 00$.

Bluse 3 eter. A second early variety growing about ten inches high pkts. se. and 10c.; per qt. 30c.; per $1 / 4$ bush. $\$ 1.50$; per bush. $\$ 5.50$.

Trarming Star.-An Extra Early. Pkts. 5c. and 10c.; per qt. 20c.; per $1 / 6$ bush. $\$ 1.10$; per bush. $\$ 4.00$.

Xeirst and Best.-One of the types of Philadelphia Extra Early of which there are variable selections. Plsts. 5c. and 10c.; per qt. 20c.; per $2 / 4$ bush. $\$ 1.10$; per busl. $\$ 4.00$.
Ear1y Izent.-This comes in after Landreths' Extra Eariy. Pkiz. 5\%. and 10c.; per qt. 20c.; per $1 / 4$ bush. $\$ 1.10$; per bush. $\$ 1.00$

Phiaciphia Extra Early.-Form of Extra Eary. The t5Te usually sold throughout the country as the first early. Plats ac. and 300 per q t. 20c.; per $1 / 4$ bush. $\$ 1.10$; per bush. \$100.

Improved Daniel O'Rourke.-Pkts. 5c. snd 10c; jer q. 250 per $1 / 4$ bush. $\$ 1.20$; per bush. $\$ 1.50$.

Early Frame (EARLY WASHINGTON, EAPLIY YAT DASIEL O'ROEZE D ETC.). - A second early sort, maturing of vine thre
bush. $\$ 4.00$.

Early Iray,-Pkts, 5c. and 10c.; per qt. 20c. ; per 1/4 basb. 8120 ; I $=8$ bush. $\$ 4.00$.

\section{INTERMEDIATE SORTS.}

Feming Gem.-An improvement upon the Little Gem. Pkts. 5c. and 10 c.; per gt. 25c.; per $1 / 4$ bush. $\$ 1.25$; per bush. $\$ 1.75$.

ICHean's I Ittre Gem.-An admirable second early, maturing for table fiftp-four days from germination. Pkts. $5 \mathrm{c}$. and 10c.; per qt. $25 \mathrm{c}$.; per $1 / 4$ brish. $\$ 1.25$; per bush. $\$ 4.75$.

SHcL.ean's Advancer.-A green wrinkled variety, maturing in flftyfive days after sprouting; vine eighteen inches high. Pkts. bc. and 10c.; per qt. $26 \mathrm{c}$; ; per $1 / 4$ bush. $\$ 1.10$; per busl. $\$ 4.00$.

rarsford's Market Garden, -A prolific and continuous producer of nods of over average size. Desirable for private garden. Plts. 5c. and 100 ; por $\$$ t. $25 \mathrm{c}$.; per $1 / 4$ bush. $\$ 1.25$; per bush. $\$ 4.75$.

an rerbearing.-Somewhat similar to Abundance. Plts. ác. and 10c.; per ot. 25c.; per $1 / 4$ bush. $\$ 1.20$; per bush. $\$ 4.50$.

Eugenie.-This is among the most luscious of all Peas; ripens sixty-three days \&fter germination. Height thirty inches. Pkts. 5c. and 10c.; per qt. aec.; per $1 / 4$ bush. $\$ 1.60$; per bush. $\$ 6.00$.

15 loomsdale. $-A$ white-seeded Pea of phenomenal productiveness of exceedingly long pods, each containing from eight to ten seeds. Most profitable to the market gardener, as produciug to the acre more than Gorale the number of barrels than any other Pea in cultivation. It produces marketable pods about two weeks after the Extra Early, and about teu days ahead of the Marrowfats. Vines deep green in color and growing to a height of thirty-six inches. It should be drilled in rows growing to a height of thirty-six inches. It should be drilled in rows
.hree feet apart. Pkts, 5 c. and 10 c.; per qt. 25 .; per $1 / 4$ bush. $\$ 1.25$; per isush.

\section{LATE SORTS.}

Meroine, - A new variety producing large recurved showy pods containing seven to eight Peas; something after the style of Pride of the Market, but deeper green both in pod and vine. The plant very stocky. Plts. $5 c$. and 10c.; per qt. $30 \mathrm{c}$.; per $1 / 4$ bush. $\$ 1.60 ;$ per bush. $\$ 6.00$.

Yorkshire Mero.-A showy wrinkled variety, maturing after the Little Gem. It is hardy, productive, and better than Champion. Pkts. 5c. asd 20c.; per qt. 20c.; per $1 / 4$ bush. $\$ 1.15$; per bush $\$ 4.25$.

Shampion of England.-Wrinkled and very sugary; requires stieleng; ripens for table in seventy days from germination. Pkts. 5c. alld 10c.; per qt. 20c.; per $1 / 4$ bush. $\$ 1.15$; per bush. $\$ 4.25$.

3 orty-fold (IMPROVEMENT ON CHAMPION). - A third early variety. Pods large, Pea wrinkled and sugary. Pkts. 5c. and 10c.; per qt. 20c.; per $1 / 4$ bush. $\$ 1.15$; per bush. $\$ 4.25$.

Telephone.-Large wrinkled seeds. Height of vine three feet. The most showy tall Pea in existence, producing from seven to ten showy .straight pods containing nine to ten Peas in a pod. Pkts. $5 \mathrm{c}$. and 10c. ser qt. 25c.; per $1 / 4$ bush. $\$ 1.25$; per bush. $\$ 4.75$.
Abundance,-A productive wrinlled rariets, maturing after the Gem Pkts. 5c. and 10c.; per qt. $25 \mathrm{c}$.; per $1 / 4$ bush. $\$ 120$; yer bush $\$ 1.5 \mathrm{u}$.

Iride of the Market.-A round blne Per. Cerraisly one of the ters of the lato introductions. Height of vine fifteen to eightwen inches. PColy of enormous size, borne nine to ten on \& rine, and containing \& mo. m5 Peas in each

Stratagem.-A blue, wrinkled, marrow, English dwart Pes of rase ex cellence. Vines twenty to twenty-four inches, bearing six so sered im-
mense pods of ten Peas each. Plkts. $5 \mathrm{c}$. and 10c.; per as. $30 \mathrm{c}$; ; bush. $\$ 1.60$; per bush. $\$ 6.00$.

Landreths' French Canner.-Sixty dass from ge:mi-asig? pod picking. Introduced by us in 1336 and privately usel s:nce by zasay canning establishments, which have made upon them a high repuia: for the quality of their goods; thes claim it possesses the rery im portant quality of not blackening under procensing. ners purchase from us from 300 to j00 bushels a rear. it is an acr it a: ant form of the French Pea used by the best establishments in Eur Fo It 10

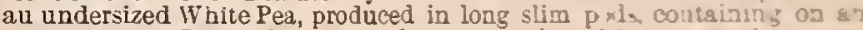
average seven Peas, often ten, and consequently, without a s. anle excep tion, the moit productire of all the Peas on our list. The rines c? : 2.4 variety grow about forty inches long, consequently the rJw: shoule be

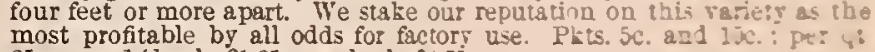
$25 \mathrm{c}$.; per $1 / 4$ bush. $\$ 1.25$; per bush. $\$ 1.15$.

Dvarf Blue Imperial.-Ripens sixty-tive ders afę fertuda. Pkts. 5c. and 10c.; per qt. $20 \mathrm{c}$; per $1 / \mathrm{s}$ bush. $\$ 110$; pur bus $\$$ i. us.

Bishop's Early Dwarf Long Pod - Ripens about serea:- dar. from germination. Pkts. 5c. and 10c.; per qt. $3 \mathrm{c}$.; per ${ }^{2}$ bush 51 is. jo: bush. $\$ 1.50$.

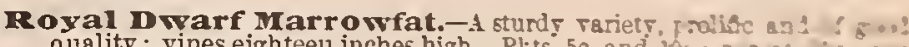

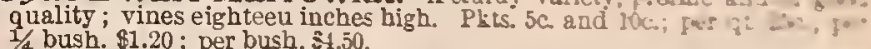

Main Crop Long Island Marrowfat. market gardeners in New Jerser in place of the old whie $\mathrm{Yan}$ being productive, more showy in the basket and far beliet in fia pods having somewhut the appearance of Telephones, but are ea?

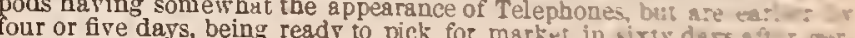
mination. Pkts. 5c. and 10c.; per qt. 30c.; per 2, bush ofl(a): $\$ 6.00$.

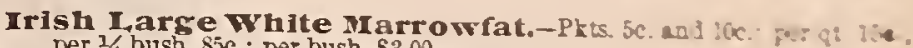
per $1 / 4$ bush. 85c.; per bush. $\$ 300$.

Peruvian Black-Eyed Marrowfat.-Plang on the s. sit. Pha 5c. and 10c.; per qt. $15 \mathrm{c}$.; per $1 / 4$ bush. S5c.; per bush $\$ 0$.

\section{EDIBLE SUGAR PODS.}

\section{Pods used same as Snap Beans.}

Dwarf Purple Blossom Sugar.-Matures in seventy dags from germination. Pkts. 10c.; per qt. $35 \mathrm{c}$.; per $1 / 4$ bush. $\$ 1.80$; per bush. $\$ 7.00$.

W warf White Blossom Sugar.-Height of vine twenty inches : pods small but crowded with Peas. We are now able to meet a frequent demand for a small-seeded Dwarf White Blosso:a Sugar. Pkts. 10c.; per at. 35 c.; per $1 / 4$ bush. $\$ 1.80$; per bush. $\$ 7.00$.
Dwarf Purple Blossom but Sugar.-Same general chances an ibe $\$ 1.80$; per bush. ST 00 , but taller. Plts. 10c.; per qt ssic : per 1 is ist

Tall White Blossom Sugar.-Eeight thirt aix loctar large. We are at last in a position to till on thirt six lockar pas

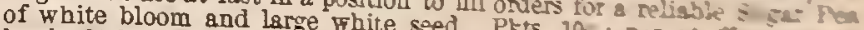
bush. $\$ 1.80$; per bush. $\$ 1.00$.

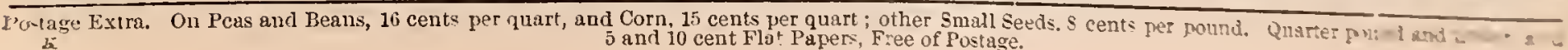




\section{PEPPER.}

Capsicum Annuum-Piment-Płeffer-Pimiento.

ONE OUNCE OF SEED TO 100 YARDS OF ROW.

Start the plants under glass in early Spring, or outside when the Apple is in bloom, against the shelter of a board fence or garilen wail. Transplant ariet Corn-planting time, setting in rows at three feet and two feet in the row. Under good cultivation 200 to 350 bushels showd be grown to the acre. The hest prices for Peppers are obtained after frost. Commission merchants pay the truckers 40 to 50 cents per bushel for first picking but later on the rome increases.

Small Chili Red.-Fruit red, small, ovoid very hot. Pkts. $5 \mathrm{c}$. and 10c, i per $0 z .35 \mathrm{c}$; ; per $1_{4} 1 \mathrm{~b} .95 \mathrm{c}$. ; per lb. $\$ 3.50$.

Very Small Casrenne.-Very superior to the old Cayenne. Exceedingly productive bearing fruit all over the plant, as plentiful as foliage. Fruit one inch in length and very hot. Pkts. 5c. and 10c.; per oz. 35c.; per $1 / 41 \mathrm{lb}$. $95 \mathrm{c}$; ; per lb. $\$ 3.50$

Cayenme.-Fruit three inches in length and slender, very hot. Pkts. 5c. and 10c.; per oz. 30 c; per $1 / 41$ lb. 85 c.; per lb. $\$ 3.00$.

Red cherry. - Ornamental round pickles. Plits. 5c. and 10c.; per oz. 35c.; per $1 / 4 \mathrm{Ib}$. 95c.; per 1b. $\$ 3.50$.

Golden Bel1. - Similar in form to Sweet Spanish. Pkts. 5c. and 10c.; per 0z. 30c.; per $1 / 4 \mathrm{lb}$. 85c.; per lb. $\$ 3.00$.

Tomato, or Squash Shaped, or Bonnet.-Used for pickles. Fruit red and flat, like a Tomato. Pkts. 5c. and 10c.; per oz. $30 \mathrm{c}$; per $1 / 4 \mathrm{lb}$. $85 \mathrm{c}$.; per lb. $\$ 3.00$.

Large Sweet Spanish.-The large red variety generally used for pickles. Pkts. $5 \mathrm{c}$ and 10c.; per oz. 30c.; per $1 / 4$ lb. $85 \mathrm{c}$.; per $1 \mathrm{~b}$. $\$ 3.00$.

Hullmose. A variety producing larger fruit than the Sweet Spanish, but in other respects similar in appearance, very hot. Pkts. 5c. and 10c.; per 0z. "30c.; per 1/4 1b. 85c.; per lb. $\$ 3.00$.

Celestial.-Vers productive, some plants producing as many as one luundred and fifty fruit, corrical in shape. fruit from one to two inches long. Fruit green from the blossom, turning alternately to lemon, golden and scarlet. Pkt. 10c.; per oz. 50c.

Reuby Iring.-A French variety producing dark-red fruit, mammoth in size ; foliage very large and showy; habit late. P.kts. 5c. and

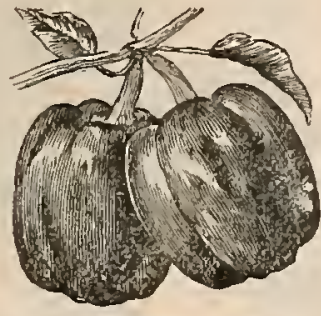

Sweet Sparlsh Pepper.

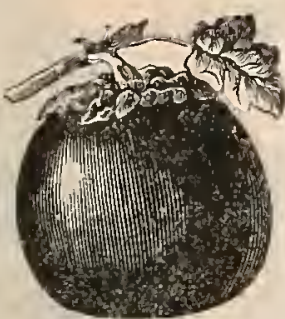

Large Purplo Egg-Plant。

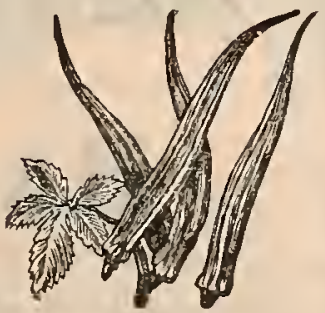

New South Okra,

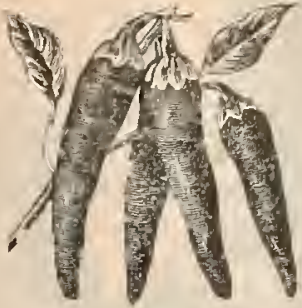

Cayenno Pepper.

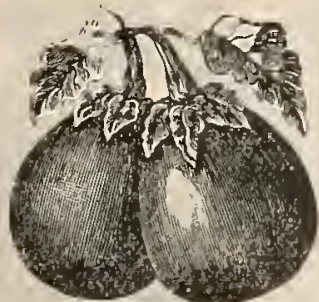

Large White Egg-Plant.

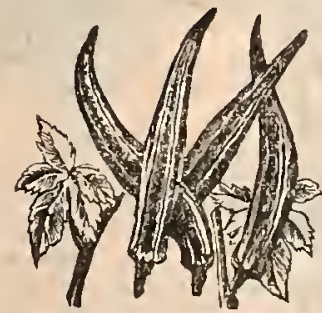

Long Green Pod Okra.

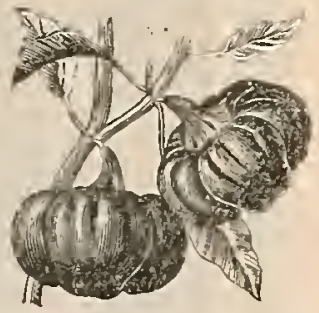

Tomato-shaped Pepres

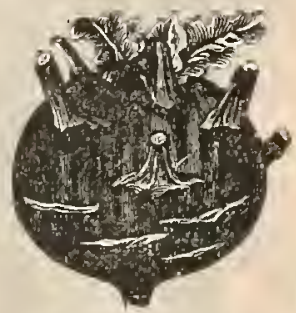

Purple Kohl-Rabie

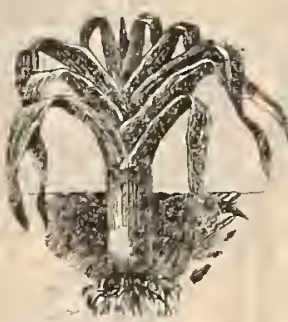

Carentan Leek,

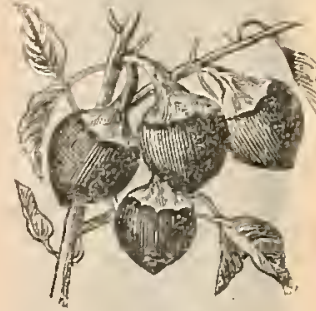

Cherry Peppe?,

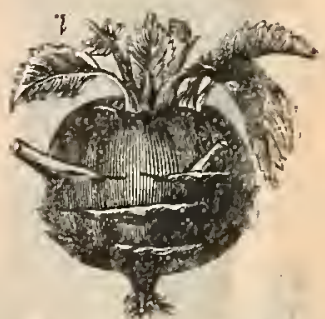

White Vienna Kohl-Falis

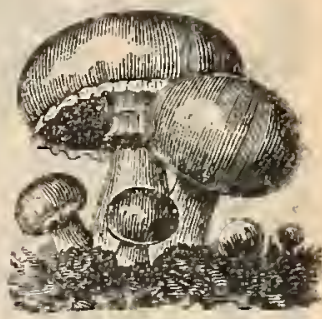

Mushroams:

\section{PUMPKIN.}

Oucurbita-Potiron-Calabaza-Sïrbis für Torten unb ßies-Centner Aræakar.

TWO QUARTS TO THE ACRE. HILLS EIGHT BY EIGHT FEET.

The time for planting this seed varies from the first Corn planting until probably a month subsequently. Later than that $\varepsilon$ successful crop cannot be expecie as this plant requires a long season of growth. When grown with Corn every fourth hill of every fourth row may be planted in Pumpkin seed. During the working of the Corn the Pumpkin plants will stand unbarmed, and after the Corn culture ceases the Pumpkin vines will extend over the field, cover ing it entirely if the soil be rich.

NOTES ON COOKING.-No. 223.-PIE.-Peel, cut in pieces and remove seeds, put over fire with water and cook until tender, mash or pass through a sieve, add powdered sugar, cream, allspice, nutmeg, six eggs, small quantity of brandy, teaspoonful cooking ginger, mix well, bake in moderate oven with one layer of dough.

Vellow Cashaw. - The best among the Pumpkins; weight, as high as 60 to 100 pounds. Pkts. 5c. and 10c.; per oz. 10c.; per 1/4 lb. 20c.; per lb. $70 \mathrm{c}$.

Cheese.-A very good table variety. Shape fiat like a cheese box; a goet keeper. Pkts. 5 c. and 10c.; per oz. 10c.; per $1 / 4$ lb. 20c.; per 1b. 60 c.

Common Field.-Pkts. $5 \mathrm{c}$. and 10c.; per $0 z .10 \mathrm{c} . ;$ per $1 \mathrm{~b} .30 \mathrm{c}$

\section{RHUBARB.}

Rheum hybridum-Rhubarbe-Mbabarber-Ruibarbo-Rhabarber.

FOUR OUNCES OF SEED WILL SOW 100 YARDS. TEN POUNDS TO THE ACRE,

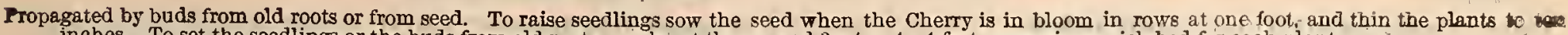
inches. To set the seedlings or the buds from old roots, mark out the ground $3 \times 4$ or $4 \times 4$ feet, preparimg a rich bed for ench plant.

Sucess can only be attained on well-manured ground. The fertilizing cannot be overdone.

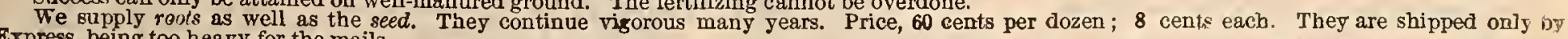
Sow beed in the heavy for the mails.

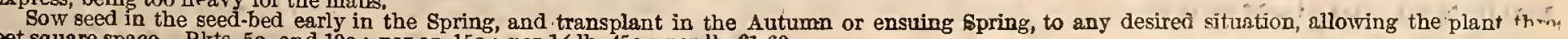
Sow seed in the seed-bed early in the Spring, and transplant in the Autumer
feet square space. Pkts. 5c. and 10c.; per 0z. 15c.; per 1/4 lb. 45c.; per lb. $\$ 1.60$.

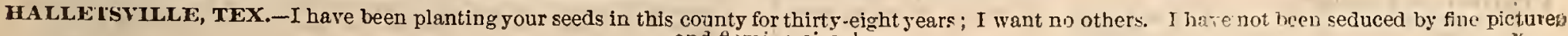
and flamiug circulars. 


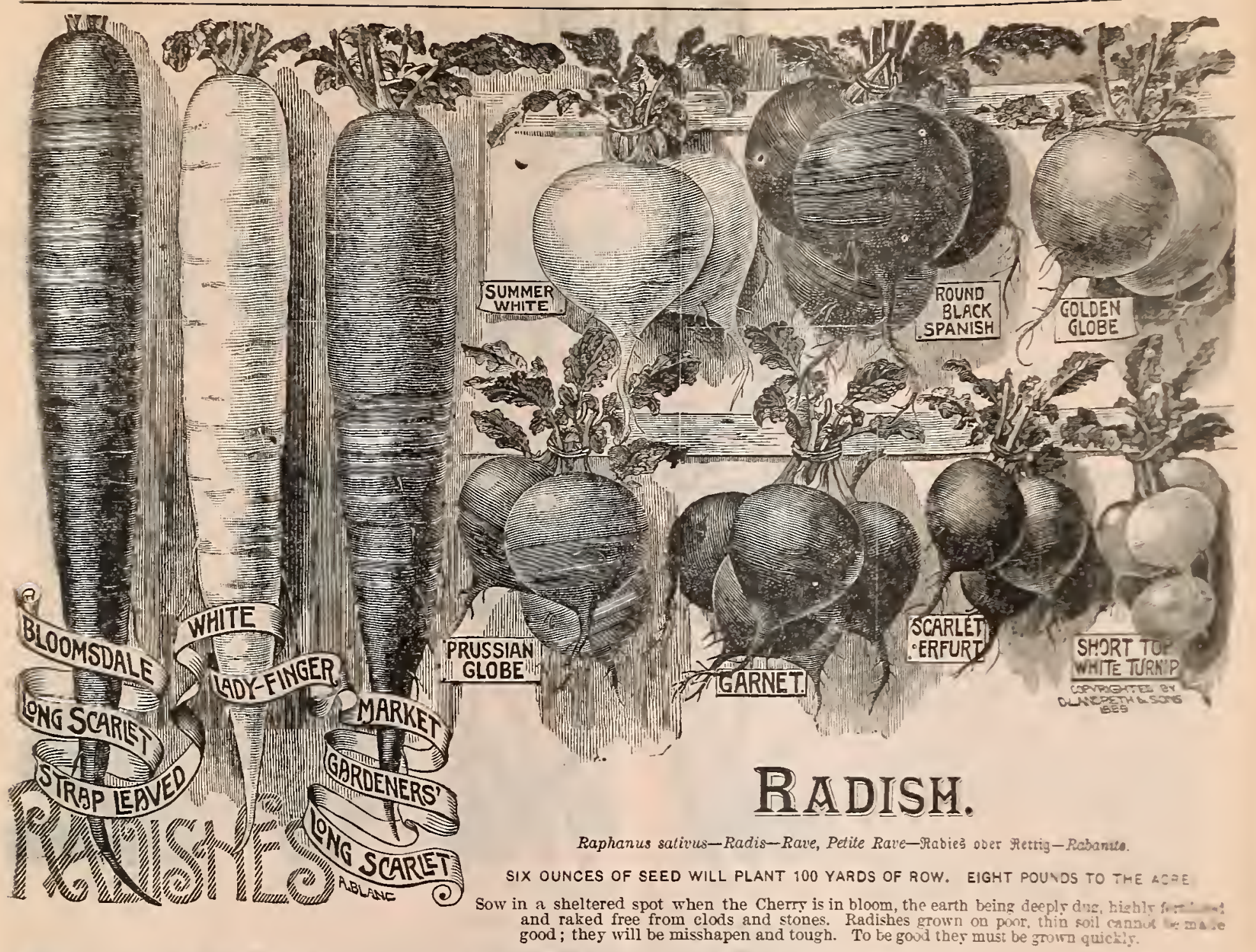

Bhort-Top Earliest White Turnip.-Serenteen days to maturity. The earliest white-rooted Radish, the best white for forcing, leares being very few, short and closely set, bulbs very choice in form and delicate in texture and

- arly Carnet.-Eighteen days to maturity, The earliest red-rooted Radish. It unites two marked qualities: First, an earliness in maturity for table, surpassing any other red sort: secondly, a ripe depth of garnet ar ruby color unapproached by any other variety. Iu form it is Turnipshaped in size and form similar to the Early scarlet. The leaves, very short and small, fit it for forcing in glass house or frame, while its early maturity will astonish the cultivator. Pkts. 5c. and 10c.; per oz. 10c.; per $1 / 4$ lb. 30c.; per lb. $\$ 1.00$.

Early Scarlet Prussian Globe.-Fighteen days to maturity. A sma?l-1eaved variety well adapted for forcing under glass : root round and carmine eolored, early, very attractive and desirable, fine for forcing. A and 10c. ; per oz. 10c.; per $3 / 4$ lb. $30 c$.; per lb. $\$ 1.00$.

Earliest Scarlet Erfurt Turnip.-Among quickest maturing of the red Turnip Radishes. Small root and small top; an excellent forcing toriety. Plits. 5 c. and 10c.; per oz. 10c.; per $1 / 4 \mathrm{lb}$. 30c.; per lb. $\$ 1.00$.

White-Tipped Early Scarlet Turnip. - A fancy French rariety; scarlet bulb with white bottom. Very showy and delicate. A 8100.

Farly Deep Scarlet Turnip-Rooted.-An improvement on the old Red Turnip; richer in color; smoother in skin. Pkts. 5c, and ICe. ; per oz. 10c.; per $1 / 4$ lb. $20 \mathrm{c}$; ; per lb. 60c.

Ear"y Red Turnip-RRooted.-Pkts. 5c. and 10c.; per oz. 10c. ; per $1 / 4$ Ib. $20 \mathrm{c}$. : per lb. $60 \mathrm{c}$.

French Breakfast (wHITE TIP).-An olive-shaped variety, the upper part of the bulb scarlet, the bottom tipped with white. Pkts. 5e. and 10c. ; per oz. 10c. ; per $1 / 4$ lb. 20c.; per lb. $70 \mathrm{c}$.
Deep Scarlet olive-Shaped.-A showy, half-long ra-er. F to

White olive.Shaped. -1 desirable sor. phis 10c.; per $1 / 4$ lb. 20c.; per lh. 70 c.

Long White Red-Crowned

and showy. with the raluable qualit of neming dition. Not offered by ally other seedsnen. Ples. $5 c$. and lic. for :

Early White Turnip.Rooted.-

,andreths' White Lady Finger.-Twentr-Lhree dar : rity. A large white crisp variety, about half as long as Long sca" is at ever introdnced. An admirable marker decided the tast of s it 1 of merit phts and 10c. per oz 130 .

Wonderful Iatf I,ong Red.-Te belies

Radish of some other firms, so rapid in growrh

as to de relop profers shoulder to a sharp point, rer srmmetricas. contrscting : a tand per $1 / 4 \mathrm{lb}$. 30c. ; ver lb s1.00.

FaIf I,onc Deep Scarlet. A rariets hsif let and of same form. Matures in tweaty dars Plis is ad in.

Market Gardeners' Early Long Scarlet Scarlet Olive and shorter than Cong Scarlet. - Lose: : in variety for forcing: fully ten days earlier this the Long suma e

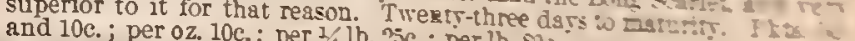
Broomsdale Tous and introduced by $11 \mathrm{~s}$. An improrement on eaved $(\mathrm{FL}-\mathrm{NL}$ value. Pkts. 5c. and 100 ther in skin, brilliant in coloz. 


\section{RADisH.-CONTINUED.}

Gong scarlet short-Top (AMERICAN).-Tbe root is long, straigbt rich and nuiform in color. American raised seed is surer to vegetate than the imported. Pkts. 5c. and 10c.; per oz, 10c., per $1 / 4 \mathrm{lb}$. 25c.; per lb. $80 \mathrm{c}$.

Wood's Early Frame.-Pkts. 5c. and 10c.; per oz. 10c.; per $1 / 4 \mathrm{lb}$. $25 \mathrm{c}$; per $1 \mathrm{~b} .80 \mathrm{c}$.

Long Scarlet short-Top (IMPORTED). - The well-known market rariety. Plsts. 5c. and 10c.; per oz. 10c. ; per $1 / 4$ lb. 20c. ; per lb. $60 \mathrm{c}$.

Early Long White Vienua. - An early long white variety of good quality. Pkts. 5c. aud 10c.; per oz. 15c.; per $1 / 4 \mathrm{lb}$. $35 \mathrm{c}$; ; per $1 \mathrm{~b} . \$ 1.25$.

Summer White (THIRD EARLY).-Tbis is a choice top-sbaped variety, resisting tbe heat of Summer aud maturing after other varieties have passed away. It is cone-shaped, tbe under portion of the bulb beiug somewbat pointed. The bulb retains its erible quality longer than most other Radisbes. Pkts. 5c. and 10c.; per 0z. 10c.; per $1 / 4$ lb. 20c. ; per lb. $70 \mathrm{c}$.

Plilladelphia White Box. - White, sbort leaved and Turnip formed. Early to develop, named "Box" by reason of its adaptability for growing in boxes, bot or cold frames. Pkts. $5 c$. and 10c. ; per oz. 10c. per $1 / 41 \mathrm{lb}$. 20c. : per lb. $70 \mathrm{c}$.

Qolden Globe (FINR FOR sUMMER). -Tbe best Snmmer Radish. Shape Tlobular; color amber; flavor mild; keeping long in eating condition. $20 \mathrm{c}$; ; per lb. $70 \mathrm{c}$.

stuttgart Round White 'Turnip (THIRD EARLY). - A very superior early white Summer and Autumn Radish, growing to large size and long standing in character; form top-shaped. Pkts. 5c. and 10c. ; per 0z. $10 \mathrm{c}$. ; per $1 / 4 \mathrm{lb}$. 20c.; per $1 \mathrm{~b}$. $70 \mathrm{c}$.
Chartier, or I, Ong Fose (SECOND EARLY).-In color the greater length of the root is scarlet and pink, while the point and bottom portion are white. Pkts. 5c. and 10c. ; per oz. 10c.; per $1 / 41$ lb. 20c. ; per lb. $70 \mathrm{c}$.

White Strasburg, or Fospital.-Lnng in form, wbite, early to develop to edible size, and keeping iu edible condition for five or six weeks. Pkts. 5c. and 10c.; per 0z. 10c.; per $1 / 4$ lb. 25 c. ; per 1b. $80 \mathrm{c}$.

California White Winter.-A long, thick root, skin wrinkled, grayisb white. Should be uved young; of good keepiug quality. Pkts. 5c. and 10c.; per $0 z$. 10c.; per $1 / 4$ Ib. 20c.; per $1 \mathrm{~b}$. $70 \mathrm{c}$.

Scarlet China Winter.-A fine Winter sort, smaller tban Spanish; root a half long stump of from two to three inches; scarlet and pink in color, tipped with white; quite salable in market during Winter. Keeps perfectly. Pkts. 5c. and 10c.; per 0z. 10c.; per $1 / 4 \mathrm{lb}$. 30c. ; per $1 \mathrm{lb} \$ 1.00$.

China Rose Winter.-Smaller than tbe Scarlet China Pkts. $5 \mathrm{c}$. and 10c. ; ver Dz. 10c. ; per $1 / 41 \mathrm{lb}$. 30c. ; per lb. $\$ 1.00$.

Ronud Rlack Spanish (THRD EARLY). - Forty days to maturity. A Winter Radish, cultivated in Autnmu and keeping like a Potato, in goor condition for months after harvesting. Tbough the outside skin is black tbe $f$ lesh is white as snow, very crisp and of good flavor. Pkts. 5c. anil

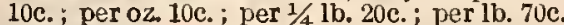

IRussian I,ong White Winter.-A Winter Radish, sometimes reacbing a weight of three pounds, and keeping long in edible condition. Pkts. 5c. and 10c.; per 0z. 10c. ; per $1 / 4$ lb. 20c.; per lb. $70 \mathrm{c}$.

I,ong White Spanish.-Valuable for Winter use. Should be better known. Pkts. 5c. and 10c.; per oz. 10c.; per $1 / 4$ lb. 20c.; per 1b. $70 \mathrm{c}$

I, Ong Black Spanish.-Difiering from tbe White Spanish only in polor. Plsts. 5c. and 10c.; per 0z. 10c.; per $1 / 41 \mathrm{~b}$. 20c.; per 1b. 70c.

\section{SALSIFY (OB OYSTER PLART).}

Tragopogon porrifolius-Salsifls-\$afermurgel ober Bodgabart-Salsif Blanca-Havrerod.

This plant prodicces an edible root, long and slim, white fleshed and smooth white skin. Leaves gray green, long, straigbt and narrow. It is a native of tine South of Europe, but only witbin the present century used as a culinary vegetable. Sow wben tbe Cherry is in bloom, in drills, in deeply-dug and wellmanured ground; the drills sbould be eighteen inches apart. When tbe plants are up a few inches weed and thin them so as to stand four or five incbes from each other. Preservo in pits, same as Carrots or Beets. Cultivate in all respects as directed for Carrot. Requires deep, rich land. Yield 100 to 150 busbels.

NOTES ON COOKING.-No. 241.-IN CrEaM. - Boil until tender, cut into thin slices, add cream or butter sauce as described under Recipo No. 2, page 4. Season to taste and garnish witb cbopped Parsley. fry crisp in very hot lard ; drain, salt, and serve hot.

No 2+3 - P ATTIEs - Trim and scrape the roots and boil in salted water wbitened with flour; drain and let cool; cut in small squares or dice and put the pieces in a good cream sauce, witb salt, pepper and a little nutmeg. Let cook for two minutes. Next fill the patties, bake brown, and serve bot,

garnisbed witb Parsley.
No. 244. - IMITATION OYsTER. - Trim and scrape the roots and boil until tender in salted water whitened witb flour; drain, and when cold mash, removing all fibres; add masbed potatoes and put in a stew-pan witb butter. Stir tbem over the fire until very dry. Add a little salt, pepper and one ol two yolks of eggs. When cold, form in cakes shape of oysters, roll tbem in cracker dust or bread crumbs, tben in a batter of eggs and bread crumbs. Fry in hot lard until brown on both sides, but not greasy. Berve bot.

Ordinary French. - This variety produces a tapering straight root of from ten to fifteen inc
$1 / 4$ lb. $35 \mathrm{c}$.; per' $1 \mathrm{~b} .81 .25$.

Sand wich Island.-A variet? superior to the French sort, producing smo ther, larger and more vigorous roots, foliage stronger and altogether a sort destined to supersede tbe old form. Pkts. $5 \mathrm{c}$. and 10c.; per oz. 15c.; per $1 / 4$ lb. $45 \mathrm{c}$.; per $1 \mathrm{~b}$. $\$ 1.50$.

\section{SCORZONER A (OR BLACK SALSITPY).}

Scorzonera hispanica-Scorsonere-Escorzonera-Sđroarzmurzel-Schorsenerred.

FOUR OUNCES OF SEED WILL SOW 100 YARDS.

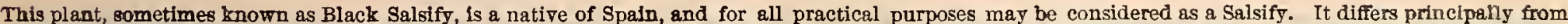

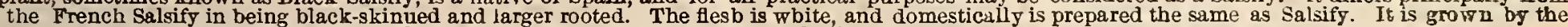
same methods of culture. Pkts. $5 \mathrm{c}$. and 10c.; per 0z. $20 \mathrm{c}$.; per $1 / 41 \mathrm{~b}$. $60 \mathrm{c}$.; per $1 \mathrm{~b}$. $\$ 2.00$.

\section{SORREL.}

Rumex scutatus-Oseille ronde-Sauerampfex-Acedera-Zuring.

$T^{*}-a t ?$ as a salad and sown in mws at twelve incbes apart and thinned to four incbes.

French.-Pkts. 5c. and 10c.; per oz. 20c.; per $1 / 4$ lb. 50c.; per 1b. 81.75 .

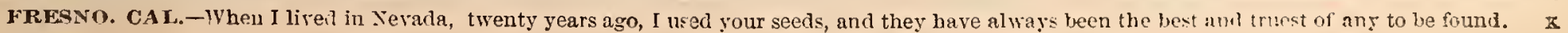




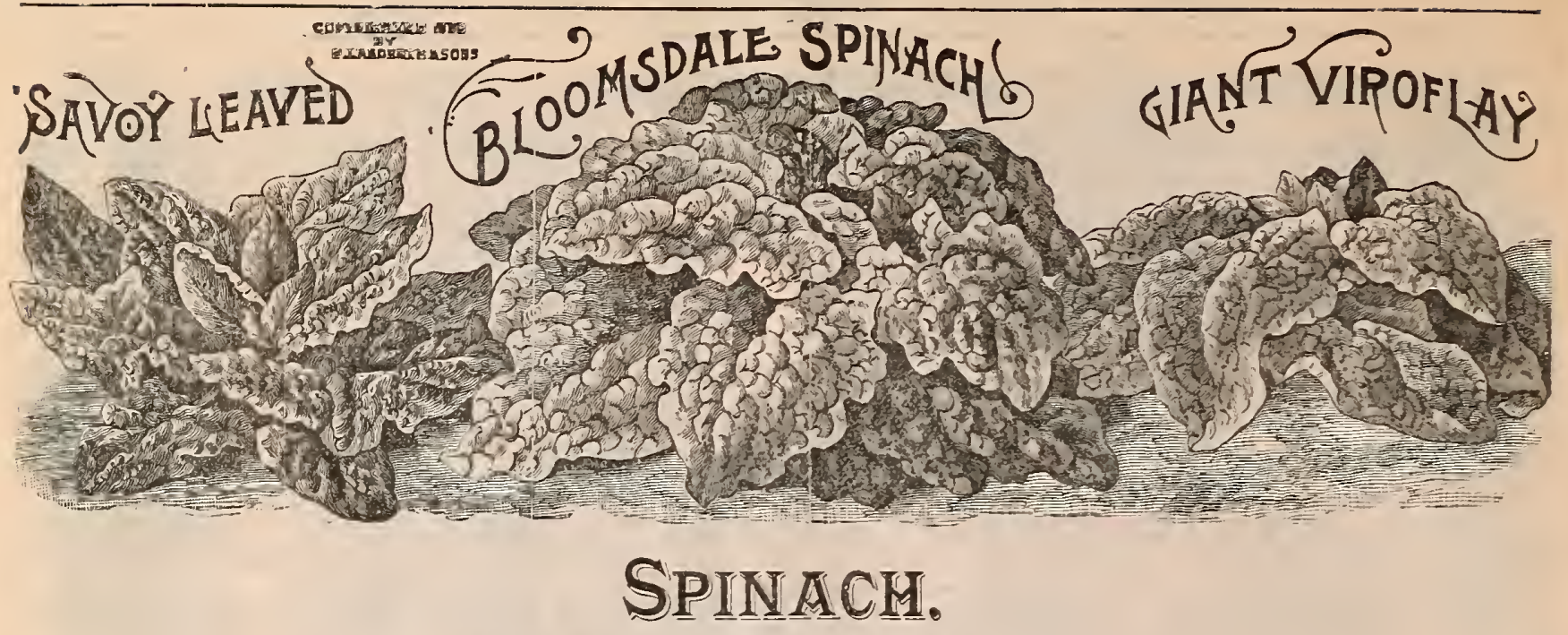

Spinacia oleracea-Epinard-Epinat-Espinaca-Spinat-Spinazie.

SIX OUNCES OF SEEO TO 100 YARDS OF ROW. THIRTY POUNDS TO THE ACRE.

rhis seed may be sown at any time excepting during the severity of Winter or the extreme drouth of Summer. When it can be grown It is alwars acceptsible. It mag be sown when the Peach is in bloom, in drills at one, two or threc feet, or broadeast, which is the nsual srstem. If sown in drills, siz ounce of seed will sow one huudred yards of row, or a square equal to teu by ten yards if sown broadcast. Yield 200 barrels.

NOTES ON COOKING.-No. 264.-STEWED.-Pick over and wash thoroughly, place on a fire in a small quantity of bolling water, add baking scri. to retain the green color, boil quickly until done, refresh. Hash rery fine and place it in a saucepan witb bntter, tablespoonful of flour, salt, peppes nutmeg and cream; cook ten minutes and serve very hot. Spinach can be cooked with pork, pig's jowls and ham.

\section{Bloomsdale Spinach. (Registered.,}

This is a form of Spinach superior to other sorts because of its leares being cur?er, twisted and bloated to an unusual degree, this curied qualits giring the leaves an elasticity especially fitting them for shipment to long distances, while at the same time giving the crop large measuring qualities, many more barrels of the Bloomsdale Spinach being cut to the scre than any other variety, and thns adding an increased profit to the shipper. It is especiall recommended for Antumn sowing, as when sown ia Springtime it shoots to seed earlier than any other sort of Spinach.

The Bloomsdale Spinach is put up in blue muslin bags of five, ten, twenty, thirty and forty pounds, fastened witb copper wire and lead-sealed with orir "Bell" trademark to distiuguish it from imitation and spurious stock. No charge for bags and sealing. We can sell at a lower price same seed as is sold by some seed merchants as Bloomsdalc, which chcaper seed is grown in Europe and is alwars of uncertain age and ritalits, to sas nothing of uncertain quality. On goor soil sixty barrels of Bloomsdale Spinsch should be cut to the acre. We have records of 125 and 150 barrels to the 8 cre Pkts. 5c. and 10c.; per oz 10c.; per $1 / 41 \mathrm{lb}$. 15c.; per $1 \mathrm{~b} .50 \mathrm{c}$.

Found Savoy Leaved.-Sold by other houses as Bloomsdale. We bere offer seed of Spinach of that variety which is sold by otber seeds. men as Bloomsdale Spinach at a low price. Bloomsdale Spinach cannot be sold at a low price, but to those who are looking for a cheaper article we recommend this, and we offer it as low as the lowest. Pkts. $5 \mathrm{c}$. and 10c.; per oz. 10c.; per $3 / 4$ lb. 10c.; per $1 \mathrm{~b}$. 30c.

IPriclis Seeded (VERY FINE).-The strain we offer is oniy inferior to the Bloomsdale. The past seasou it proved superior in a remarkable degree to a large number of sanples of Round Duteh, procured for experimental purposes. We do not hesitate to recommend it either to the family or msiket gardener. Pkts. $5 \mathrm{c}$. and 10c.; per $0 z .10 \mathrm{c}$; ; per $1 / 4 \mathrm{lb}$. 10c.; per lb. $35 \mathrm{c}$.

Common Round Dutch (IMPORTED), -To meet the low prices of other seedsmen, dealing in cheap seeds, we are forced to import and here

offer a foreign stock. Imported Spinsch is not suitable for Antumn jlanting, being of necessity one year old, perbaps more-who can tell? Pkts. 5e. and 10c.; per $02.10 \mathrm{c}$; per $1 / 4 \mathrm{lb}$. 10c.; per $1 \mathrm{~b} .30 \mathrm{c}$

L.oug Standing. - A prostrate rariety of dark color and slow to shoot to seed. Pkts. 5c. \&nd 10c.; per oz. 10c.; per $1 / 4 \mathrm{lb}$. 10c.; per $1 \mathrm{~b}$. 30c.

Large Leaved Flanders.-Preferred br some br resson of its erec? h8bit of growth. Leares halbend-shsped. Seed rerg large. Plis. je. and 10c.; per 0z, 10c.; per $1 / 4$ lb. 15c.; per $1 \mathrm{~b} .40 \mathrm{c}$.

Viroflay (xosstrous LEATED). -A mammoth sort of fair qualitr eser largely in Europe. Plits. $5 \mathrm{c}$. and 10c.; per oz 10c.; per $1 / 4 \mathrm{lb}$. $15 \mathrm{c}$.; $\mathrm{p} \in \mathrm{r}$
lb. $40 \mathrm{c}$.

\section{SEA KALE.}

Crambe maritima-Crambe-IReer ober see Rob!-Soldanela maritima-Zeekool.

Propagated both by seeds and root cuttings. When grown from seed sow when the Cherry is in bloom in three feet rows, and thin the plants to one foot apart. Stable manure and salt are its best fertilizers. As the plants only reach maturity the second season, they have to be protected from frost by covering dur ing the Winter with light litter or leaves. In Spring remove the litter and cover each plant with an inverted flower pot ar with a foot of leaf mould or dried leaves, that the young edible shoots may be forced to grow in darkness and thus become blanched.

WOTES ON COOKING.-No. 257. STEWED-Pare the stalks, wash well snd tie in bunches of eren size. Ster for trsentr minntes, or until tender.

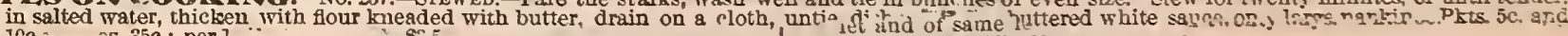
thi.

Early Deep scarlet Turnip-Rooted.-An improrement on the old Red Turnip; richer in color; smoother in skiu. Pkts. 5c. and IOc.; per oz. 10c.; per $1 / 4$ lb. $20 \mathrm{c}$; ; per lb. 60c.

Early Red Turuip-reooted.--Plits. 5 c. and 10c.; per oz. 10c. ; per $1 / 4 \mathrm{lb}$. 20c. : per $1 \mathrm{~b} .60 \mathrm{c}$.

French Breakfast (wHrTe TIP). - An olive-shaped variety, the upper part of the bulb scarlet, the bottom tipped
$10 \mathrm{c}$; per $0 z$. 10c.; per $1 / 4$ lb. $20 \mathrm{c}$; ; per lb. $70 \mathrm{c}$. oz. 10c.; per 3 ; $1 \mathrm{lb}$. 20c.; pes su. is

Market Gardeners' Early Long Scarlet. - Longer than Scarlet olire gud shorter than the old Long Scarlet. An admirable long Scarlet Olive aud shorter than the ordier than the Long Bcarlet, and very variety for forcing; fully ten days earlier than the Long searlet, 8nd rery. and 10c.; per 0z. 10c.; per 1/ lib. 25c; per lb. S0c.

ploomsdale Long Scarlet Strap-Leaved (FIS).-Namet and introduced by us. more symmetrical. smoother in skin, brilliant in color. An scquisition of malue. Pkts.5c. and 10c.; per oz. 10c.; per $\frac{1}{4} / \mathrm{lb}$. soc.; per lb. $\$ 1.00$.

-1 bave becn using your seads for thirty rears, and nerer knew them to fail. Ther are the optimates in the was of seeds 


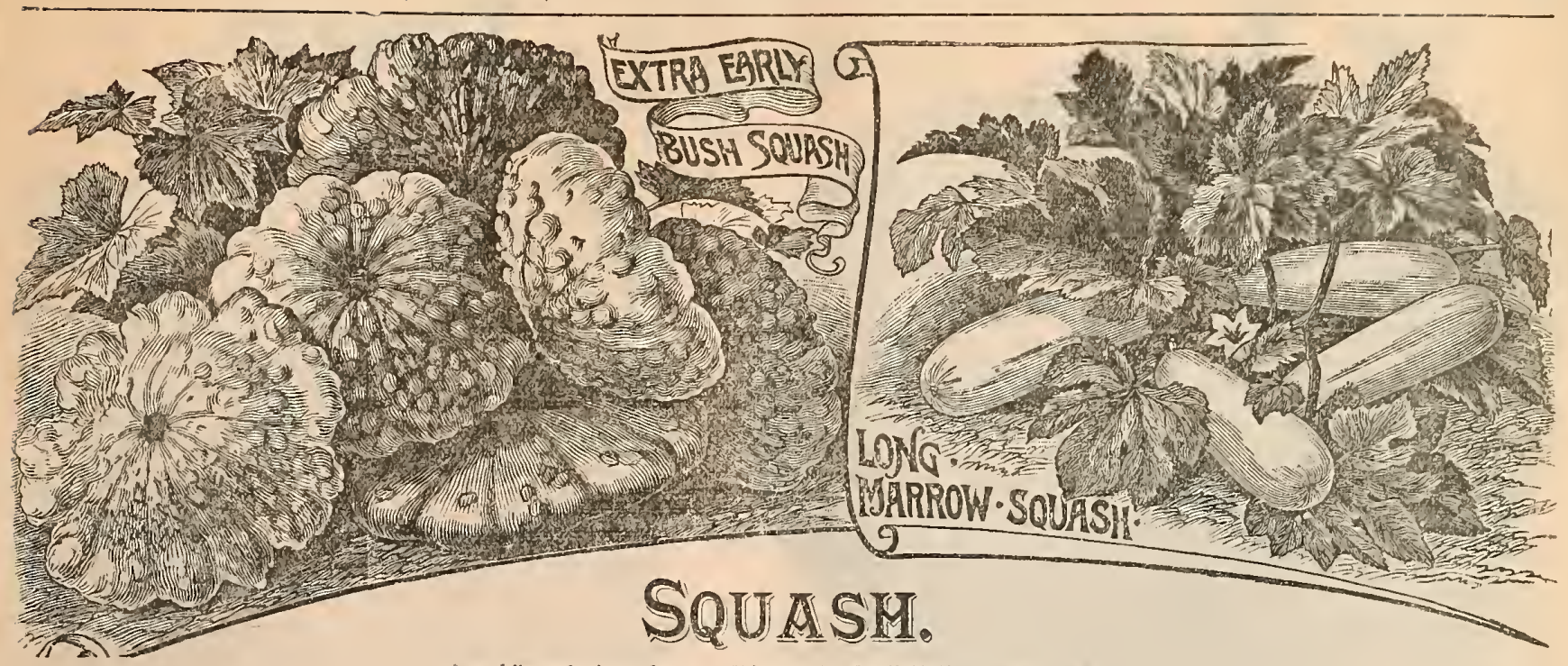

incurbita melopepo-Courge-Cidracayote-Speifeturbis-Jielon orzord:

THREE OUNCES OF SEED WILL. SOW 100 VARDS. THREE FOUNDS TO THE ACK:

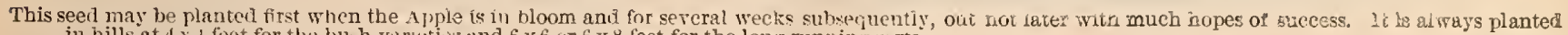
in hills at $4 x+$ feet for the bush varieties and $6 \times 6$ or $6 \times 8$ feet for the long running surts.

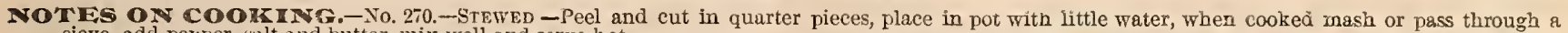
sieve, add pepper, salt and butter, mix well and serve hot.

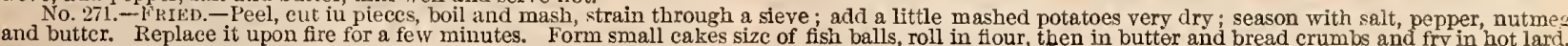

Extra Earily Busli,-Earlier by a week than the ordinary White Bush or Cymling, maturing fruit for table use in torty days from germinaBush or Cymling, maturing fruit for table use in torty days from germination, excecdiugly productive and profitable to the market gardener. The fruit when young and waxy is white, the same as the old White Bush, but
when it becomes hard it turns yellow. The plant is not in the ordinary sense a vine, as it dues not run, being in habit what is known as a bush. It will cover a space two or three feet in diameter, according to the soil and fertilizer. It will do well on light thin soils. Pkts. $5 \mathrm{c}$. and $10 \mathrm{c}$; ; per oz. 10c.; per $1 / 4$ lb. 30c.; per lb. $\$ 1.00$.

Early White Bush.-The "Cymling" of the Southern States, maturing fruit for table fifty days from germination. Pkts. 5c. and 10c.; per oz. $10 \mathrm{c}$; per $1 / 4$ lb. $25 \mathrm{c}$.; per $1 \mathrm{~b} .80 \mathrm{c}$.

Colden Summer Crook-Neck.-Among the best of the Summer Squashes, golden in color, Pkts. 5c. and 10c.; per oz. 10c.; per $1 / 41 \mathrm{~b} .25 \mathrm{c}$; per $1 \mathrm{~b} .80 \mathrm{c}$.

Perfect Gem.-Pkts. Bc. and 10c; per 0z. 10c; per $1 / 41 \mathrm{~b} .25 \mathrm{c}$; per 1b. 75c.

Barbadoes cluster.-Fruic egg-shaped and about eight inches long; exceedingly productive, bearing fruit clustered like eggs in a nest. Pkts. 5c. and 10c.; per oz. $40 \mathrm{c}$.

I.andreths" White Turban.-A variety ready for use in Midsummer, and yet is a most desirable sort for Winter purposes. So good keeper that we have had the fruit of one season keep in perfection till the fruit of the following season was in-a full twelve months. Shape a thiek conical form of the Early Bush or Patty Pall, and three times its weight. Vinc a runner. Pkts, 5c. and 10c.; per oz. 10c.; per $1 / 4$ 1b. 25c.; per lb. $80 \mathrm{c}$.
Long Green Summiner Crook-Neclk (SECOND EARLY).-The best of the Squash family, but being a very shy producer, an expensive seed. Pkts. 5c. and 10c.; per oz. $10 \mathrm{c}$.; per $1 / 4 \mathrm{lb}$. $20 \mathrm{c}$.; per $1 \mathrm{~b}$. $70 \mathrm{c}$.

Z,ong Marrov.-One of the varieties of Vegetable Marrow Squash adapted for cooking like Egg Plant, from which it can hardly be distin guished. Pkts. 5c. and 10c.; per 0z. $30 \mathrm{c}$.

Mammoth Chill.-This variety sometimes reaches a size larger than a washtub and a weight of 200 pounds. Try it. Pkts. 5c. and 10c; per oz. $20 \mathrm{c}$; per $1 / 4$ lb. 50c.; per $1 \mathrm{lb} . \$ 1.75$.

Winter Crook-Neck.-A good ireeper, shaped like a small Cashaw Pumpkin. Pkts. 5c. and 10c.; per oz. 10c.; per $1 / 4$ lb. 25c.; per 1b. 75 c.

Bogton irarrow.-Pkts. $5 \mathrm{c}$. and 10c.; per oz. 10c.; per $1 / 4$ lb. $30 \mathrm{c} . ;$ per lb. $\$ 1.00$.

I.arge Boston ATariow (EXTRA LARGE FOR CANNERS).-A meaty selection intended to count in the factory. Pkts. 5c. and 10c.; per $0 z$. $10 \mathrm{c}$ per $1 / 4$ lb. $25 \mathrm{c}$.; per $1 \mathrm{~b} .75 \mathrm{c}$.

IMubloard.-Pkts. 5c. and 10c.; per oz. 10c.; per $1 / 41 \mathrm{lb} .25 \mathrm{c}$; per 1b. $75 \mathrm{c}$.

Marblehead. - Pkts. 5c. and 10c.; per oz. 10c.; per $1 / 4$ lb. $25 \mathrm{c}$.; per lb. $85 \mathrm{c}$

\section{SHALIOTS.}

Allium Ascalonicum-Echalote-Sdjalotten-Chalote-Sjalot.

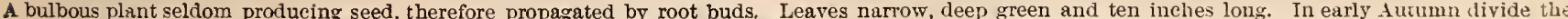

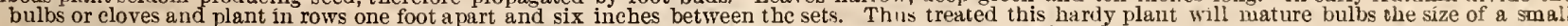
walnut three or four weeks earlier than Spring Onions. The sets planted in early Spring will mature in July.

Pear Shaped.-Per qt. 25c.; per bush. $\$ 1.50$.

| Jergey.-Per qt. 25 c.

\section{SORREL.}

Rumex sculatus-Oseille ronde-Salierampfer-Acedera-Zuring.

Toer? as a salad and sown in mws at twelve inches apart and thinned to tour inches.

Fremch.-Pkts. 5c. and 10c.; per oz. 20c.; per $1 / 4$ lb. 50c.; per lb. $\$ 1.75$.

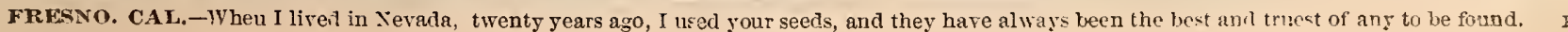




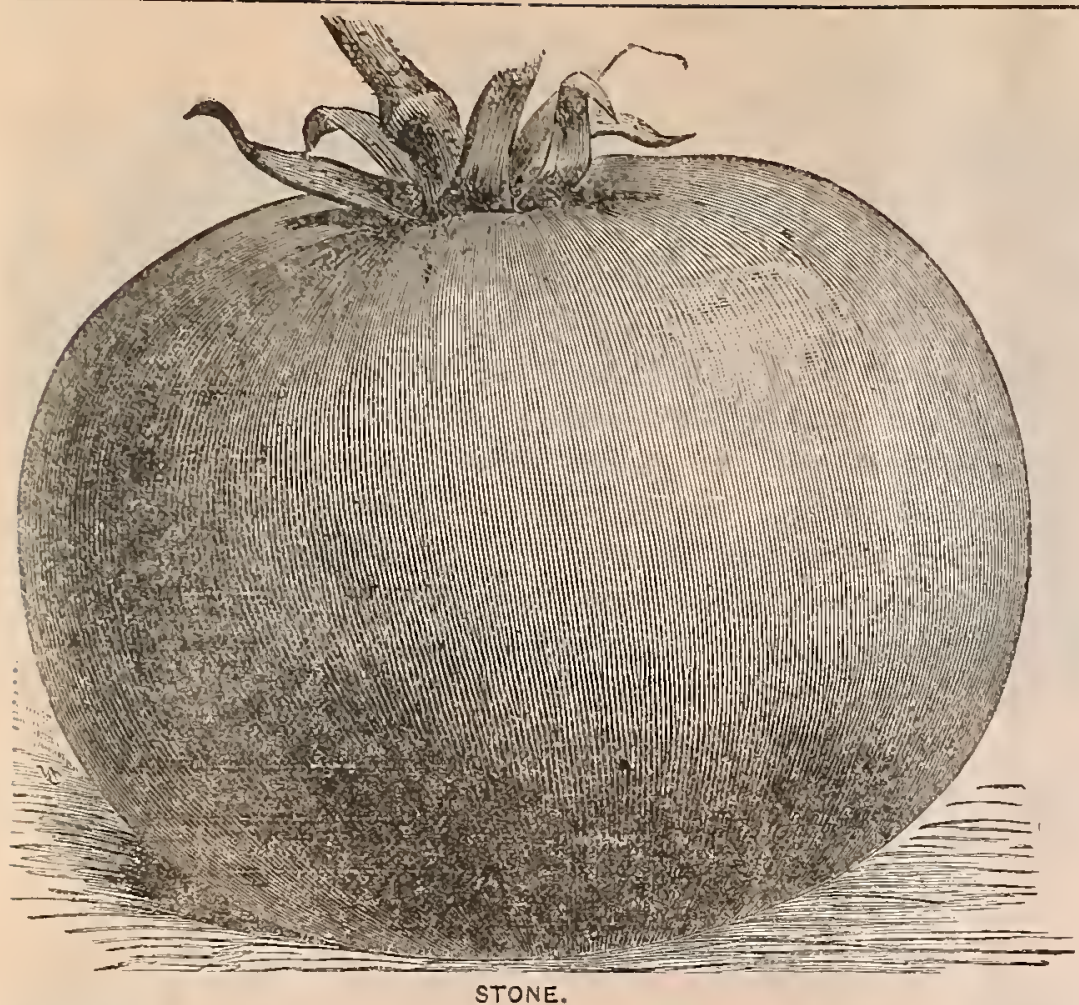

\section{TOKATO.}

Solanum Lycopersicum-Tomate-2iebeacrfei-Tomate-Tomsc?

ONE OUNCE OF SEED WILL SOW 100 YAPDS.

When the Apple is in bloom sow in hills three feet a a a on $\&$. border, early iu the spriug. For a later supply. sow a shor. um border. early in the sping situation. As the planis arvence afterwards iu more open sishwood. To bare the Tomaio t? growth support them by brush wants in 2 hotbed. or tber zas t= enrly it is necessary to start the plants in 2 hot vedsequer 213 . reared is plauted.

Plants for an early cropshould be raised unde: g'sss. ternediate erop ther mat be raised on outside bets. crops the seed may be planted in permaner: Jxs.t.02 A pple is in bloom. The arerage production of Apple is in bloom. The arerage production of
cultivated and fertilized land is about 14.000 pound,
bushels per acre, though 18,000 or 20,000 powas bare bet

Southern Florida Tomatces reach Phila "elphia in Fe? and command $\$ t$ th $\$ i$ per bushel. BP. Apre the rate de to meet the cost of transiortation. Forty to meet the cost of tras arice, twentr-fire to thit: bushel is an average lirice, twencesses to the bushel for late crops. This crop ceases to te often arug in the market. Tomaio cannirs h

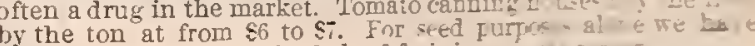
washed out over 40,000 bushels of fruit in a sing.e s.2.

\section{NOTES OF COOKJMG.-}

place iu stewing pyin

pinutes, thickel puth corn starch or breg crumb

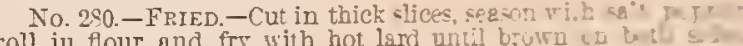
Serve hot.

Extra Farly Richmond (NINETY-DAYTOMATO).-The earliest of Tomatoes. Fair size but not smooth. A profitable variety for shipment before more aporoved varieties come in to bearing, and consequently a favorite in trucking districts in New Jersey. We have never seen an earlier l'omato in trucking cistricts in New Jersey. Richmoud It carries better than the more solid, smoother and showy sorts which, by their very perfection, are dificult to transport withont bursting, if ripe. The fruit of this variety is not smooth like an appleno extra early sorts ever are. It is, however, smooth enongh when better is not offer.d in competition, and under such circumstances it has made "big unoney" for th " truckers of New Jersey. Plits. 5c. aud 1uc.; per oz. 30 c.; per $1 / 4$ lb. 85 c.; per lb. $\$ 3.00$.

Extra Ifarly Clusteq.-Very early sorts are always irregular in ontline, or rongh irnited. This sort is no exception, but is exceedingly early aud desirable. Plis. 5c. and 10c.; per oz. 30c.; per $1 / 41 \mathrm{~b}$. $85 \mathrm{c}$. per $1 \mathrm{~b}$. $\$ 3.00$.

Early Jarsey (ONE HUNDRED-DAY TOMATn).-One of the best among the extra early sorts. Fruit good size, flattened, solid and fairly smooth color red, vines very close-jointed aud compact and admitting of close color red, sixty to a rine. Very desirable as a first early, doing well on light soils. l'kts. $5 \mathrm{c}$. and $10 \mathrm{c}$; ; per oz. $30 \mathrm{c}$.; per $1 / 4 \mathrm{lb}$. $85 \mathrm{c}$.; per $1 \mathrm{~b}$. $\$ 3.00$.

Early Eermuda (ExTRA EARLY).-This is a variety shipped from Bermuda in the early -pring to Boston. New York and Philadelphia. It is red. early, and, thongh not by ally means a first-class Tomato, has been found the most profitable of all varietics by reasou of its tough rind fitting it for long shipment. Recommended to truckers. Plts, $5 \mathrm{c}$. and 10c.; pcr oz. $30 \mathrm{c}$.; per $1 / 4$ lb. $85 \mathrm{c}$.; per $1 \mathrm{~b} . \$ 3.00$.

The nIorey Iraker.-No other Tomato so quick to ripen and more mouey making for early shipment to distant markets. Foliage silvery and large. Frnit borne in bunches, red, flattened. slightly irregular in form. An elasticity of character of fruit fitting it for long shipments. Will do well on light sandy soil. Pkts. 5e, aud 10c.; per oz. 30c.; per 1/4 1b. $85 \mathrm{c}$.; per lb. $\$ 3.00$.

Atladutic Erize.-An early smooth red sort, rery productive. Plits. 5c. and $10 \mathrm{c} . ;$ per oz. $25 \mathrm{c} . ;$ per $1 / 4$ lb. $65 \mathrm{c}$; p per $1 \mathrm{~b}$. \$2.25.

A crme.-An early ripener, size medinm. Shape slightly oval and smooth. Color maroon or red with a slight tinge of purple : flesh deep scarlet and solid. A popular sort everywhere. Plts. 5c. und 10c.; per oz. 30c.; per $1 / 4$ lb. $85 e . ;$ per lb. $\$ 3.00$

Baltimore Prize Talzer.-A large apple-shaped Tomato, smooth, solid, ripening all over, without core; color red with slight purple tint; very productive and commanding quick sale

T T T or Ter Ton Tomato.-Profitable to the grower, profitable to the canner. profitable to the shipper. This seed was grown on a twentyacre patch on one of our farms in a location twenty miles removed from any other Tomato field. Frnit deep red, large, rouud, half flat, smooth as an Apple, free from green core or other imperfections; 20,000 pounds or ten tons to the acre can readily be grown on any good Tomato soil. T T T stands for Ten Ton Tomato, the name being intended to imply ten tons to the acre. Even this may be rery much exceeded, as we have ourselves the fruit on an acre. The fruit in form is large. grown 600 bushels of the fruit on an acre. The fruit in form is large, slightly fiattened at both stem and blossom ends. Exterior smooth as an Apple. Color blood red. The fruit sut across or transversely shows a
solid meaty interior, free from air spaces or hard core. No other sort is more solid, and it takes fewer baskets to weigh a ton. It is a profitable rariety both to the farmer and the canner. Pkts. 5c. and 10c.; per oz. $30 \mathrm{c}$.; per $1 / 4 \mathrm{ib}$. $85 \mathrm{c}$.; per $1 \mathrm{~b} .83 .00$.
Beauty.-Well named Frit largeand shom: tone of purple; growing on the rines in and 10c.; per oz. 25c.; per $1 / 41 \mathrm{~b}$. $65 \mathrm{c}$; per $1 \mathrm{~b}$. 2.

Stone.-A very superior sort, producingertronitirer.

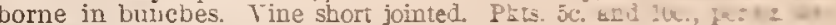
per $1 / 41 \mathrm{lb} .85 \mathrm{c}$; ; per $1 \mathrm{~b} . \$ 3.00$.

Dvarf Champion.-Stems short. thick, s: Leaves very dark in color, much curled ard d twisted.

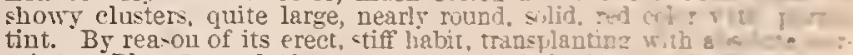

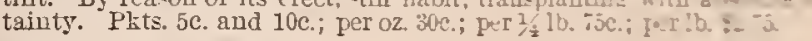

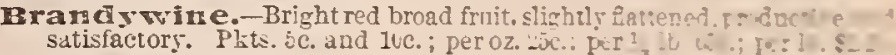

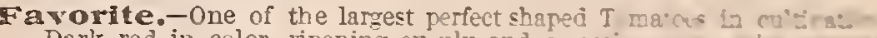

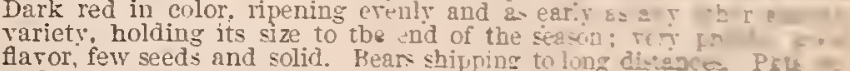

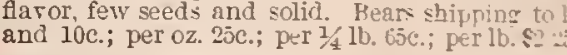

Ygrotum.-For some rears pact a farovite raries in re-ain large

Chemin or Apple.-Producing a ret fruit of medium $s^{\circ} z$

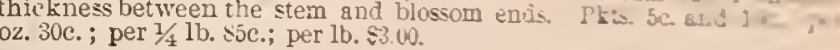

Few Golden Queen.-Plsts. 5c. and 20c; peraz ncic.: pr: - it per lb. $\$ .50$.

Peach (sEcoND EARIY), - Trmed and introduced

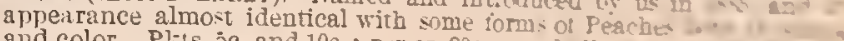
and color. Plis. 5c. and $10 \mathrm{c}$; ; per oz.

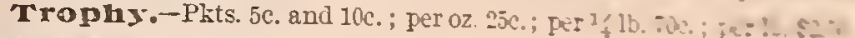

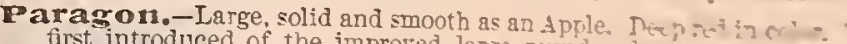
selected not yet surpassed. The Tarietr adrutived is a w e s.

Perfection.-A superb Tomato. but so nog- the charde

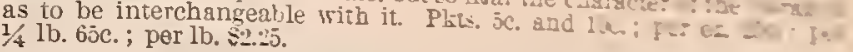

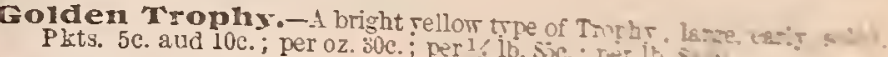

Fejee Improved ("BEEFTLAK") - Colo" marang a per $1 / 4$ lb. 70c. ; per lb. $\$ 2.50$.

Grape. Cheriy or Currant. -5 for pickles or preserves. Omsmental. Pbts. jc. ind lice: ret des z ce

Pear-shaped Fellow.-Phts, $5 \mathrm{c}$, gnd $10 \mathrm{c}$ 75c.; per lb. $\$ 2.75$.

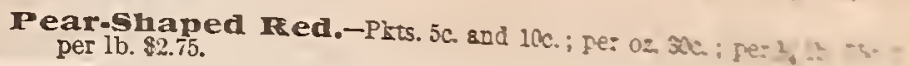




\section{TABLE TURNIP.}

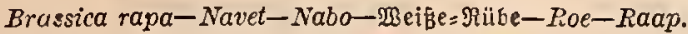

THREE OUNCES OF SEED WILL SOW 100 YARDS. FOUR PUUNDS TO THE ACRE.

Turnip seed may be sown when the Peach is in bloom or among the first seeds in early Spring; indeed, the only hope of a successfil Spring crop is in au early start, as otberwise the period of maturity extends into hot weather, when the bulb becomes fibrous and pungent. Nidsummer and carly Autumn are the seasons for successful Turnil drilling, though frequently the conditions of the soil then are not favorable to satisfactory vegetation.

The seed of Cattle Tumips is al ways drilled in rows, while the early-maturing and surface-rooted Table Turnip is generally sown broadcast. We advise the sowing, either in drills or broadcust, of not less than three pounds to the acre to insure a satisfictory stand.

The Bloomsulale Swede, like other Ruta Bagas, is slower in growth than rough-leaved Turnips, but prorluces roots more solid and more nutritious - less laxative and more fattening. Tlie Ruta Baga is a gross feeder and will
do best with twenty to twenty-five tons of stable manure to the acre; when it cannot be obtained apply 500 pounds super-phosphate.

pounds super-phosphate. liable in every respect, can be furnished, and we invite all gardeners and growers of Turnips and other roots for stock-feeding to forward us their orders early.

See our prmphlet on "THE VALTE ANंN CULTURE OF ROOTS FOR STOCK-FEEDING," now in its SIXTH EDIrIoN, price twenty-five cents, bul mailed Free to all customers of Landreths' Seeds. Its pages, hesiries giving
detailed descriptionsand illustrations of the best varieties of Turnips for the table and stock-feeding, Beet 1 landetailed descriptionsand illustrations of the best varieties of Turnips for the table and stock-feeding, Beet. 11 an-
gold Wurzel, Carrots, Kohl-Rabi, Parsnip, etc., treat also of the soils best adapted to root-culture, munner of preparing the land. time of sowing, cultivation, method of saving for Winter, and give other raluable informa. tion. No grower of root crops should be without a copy.

NOTES ON COOSEMG -No. 291.-BorleD.-Pcel and cut in small pieces, boil until tender, makh, add salt, pepper and butter, or serve in light cream sauce without being mashed.

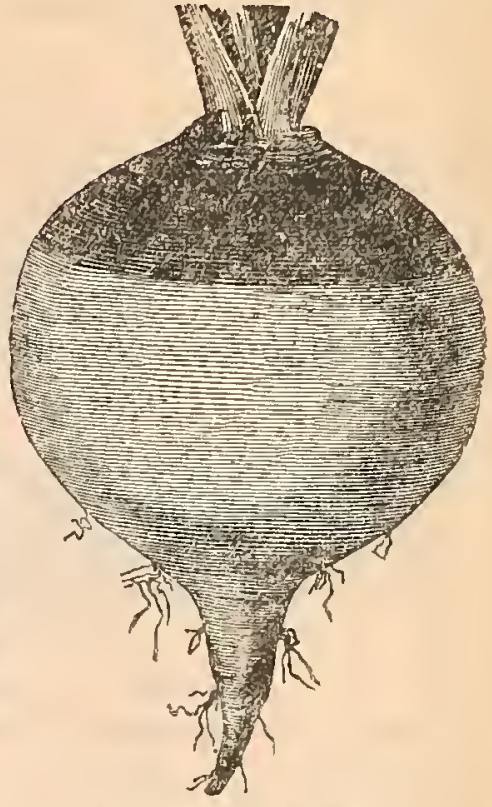

BLOOMSDALE SWEDE.
Earliest Bloomsdale Ifed-TOP (EXTKA EARIY).-This is the earliest Turnip, of any form or color, that it has ever been our fortune to earliest Turnip, of any form or color, that it has ever been our fortune to so much earlier as certainly to be considered a distinct and choice variety, and as such we recommend it. Plst. $5 \mathrm{c}$. and $10 \mathrm{c}$.; per oz. 10c.; per ety, and as such we reco
$1 / 4 \mathrm{lb}, 20 \mathrm{c}$.; per $1 \mathrm{~b}$. $60 \mathrm{c}$.

EarIy Flat Red, or Horple-TOR (STRAP-LEAVED).-Pkts. 5c. and 10c. ; per oz. 10c. ; per $1 / 4$ 1b. $15 \mathrm{c}$; ; per $1 \mathrm{~b} .40 \mathrm{c}$.

Early Flat Dutch (STRAP-LEAVED).-PLts. 5c. and 10c.; per oz. 10c.; per $1 / 4 \mathrm{lb} .15 \mathrm{c}$.; per $1 \mathrm{~b} .40 \mathrm{c}$.

Iarge Early Ked-'TOp G10be.-Large size, rapid growth, unusually attructive, aucl admired by all. A very much heavier producer thals either of the precering. We confidently recommend it as an acquisition. Pkts. 5c. and 10c.; per oz. 10c.; per $1 / 41 \mathrm{~b}$. 15c. ; per $1 \mathrm{~b} .40 \mathrm{c}$.

Early Snoveball (EXTRA EARLY).-This is a small white globe, very quick, eurliest in maturity of its form and character. We highly recommend it for trble purposes. Pkts. 5c. and 10c.; per oz. 10c.; per $1 / 4 \mathrm{lb}$. 15c. ; per $1 \mathrm{~b} .5 \mathrm{cc}$.

Jersey Li1y.-Early, globular in form, rery showy and desirable; all white. Recommelled for prirate and market garden. Pkts, $5 \mathrm{c}$. and 10c. per oz. $10 \mathrm{c}$; per $1 / 4$ lb. $15 \mathrm{c}$. ; per $1 \mathrm{~b}$. $50 \mathrm{c}$.

Early White rgs.-Esg-shaped and white, as its name indicates. Plis. 5c. and 10c.; per oz. $10 \mathrm{c}$; ; per $1 / 4$ lh. $15 \mathrm{c}$.; per $1 \mathrm{~b} .50 \mathrm{c}$.

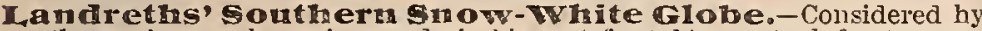
those who hest know it, as a desirable sort for tuble or stock for Autumi and early Winter use. Color, pure white : shape round, size large, solid, and early Winter use. Color, pure white : shape round, size large, solid, quick in growth for a large Turnip. Producing a great weight to the rapidly growing in popular favor, more especially as a late Winter and Spring variety. In the Autum n and early Winter it is apt to be hard, hut mellows like an Apple by keering. We recommend this to stock-breeders for early feeding, also for sowing at seasons too late to secure a crop of Ruta Bagas. It is productive, hardy, and eclipses the Norfolk, the Stone or the Pomeranean. Pkts. 5c. and 10c.; per 0z. 10c. ; per $1 / 41 \mathrm{~b}$. 15c. ; per 1b. $50 \mathrm{c}$.

Yellow Stone.-A round yellow, green-topped variety, resembling the Amber (ilobe, but not reaching so large a size. Pkts. 5c. and 10c. ; per oz. 10c. ; per $1 / 4$ lb. 15̄e. ; per lb. $50 \mathrm{c}$.

Colden Ball.-A small Yellow Turnip of second size, early and a good keeper. Hkts. 5c. and 10c.; per oz. 10c.; per 1/4 1b. 15c.; per lb. 50c.

Poneranean White Globe.-This is a free-growing, rough-leaved sort useful for hoth table and stock, and may bc highly commended for both purposes. Pkts. 5c. and 10c. ; per oz. 10c.; per $1 / 4$ lb. $15 \mathrm{c}$; ; per lb. $40 \mathrm{c}$. COW-M Or1 (LARGE CROPPER).-This variety is pure white, excepting a
dash ot green at the crown, and in shape is long like a Carrot. Plits. $5 \mathrm{c}$. and $10 \mathrm{c}$. ; per oz. 10c.; per $1 / 4 \mathrm{lb}$ l. $20 \mathrm{c}$. ; per lb. $60 \mathrm{c}$.

Crarge Norfolk.-Recommendicd especially for stock-fecding. Pkts. $5 \mathrm{c}$. and $10 \mathrm{c}$; per oz. $10 \mathrm{c}$. : per $1 / 4$ lb. $15 \mathrm{c}$.; per lb. $40 \mathrm{c}$

White Stone.-Pkts. 5c. and 10c. ; per oz. 10c. ; per $1 / 41 \mathrm{~b} .15 \mathrm{c}$; ; per lh. $40 \mathrm{c}$.

White GIobe.-Valuable for cattle food. Pkts. 5c. and 10c.; per oz. $10 \mathrm{c}$; per $1 / 4$ lb. $15 \mathrm{c}$.; pcr $1 \mathrm{~b}$. $40 \mathrm{c}$.

Amber Globe, Green Crowned.-This, which we introduced in 1863 , is ulmost indispensable in every rural household. It is a vigorous free grower, valuable for hoth table and cattle feeding. Productive and good keeper. Having less top than Aherdeen, often sold for it, it may be allowed to stand closer in the row. Pkts. 5c. and 10c.; per oz. 10c. mer $1 / 4 \mathrm{lb} .15 \mathrm{c}$; ; per lb. $50 \mathrm{c}$
Antber GIobe, IRed Crowned.-A selection from the older green. crowned Amber Globe. The same in all valuable particulars, hut more ornamental by reason of the coutrast in colors of yellow and red. This variety is more nutritious than the Trhite Globe. Pkts. 5c. and 10c. ; per oz. $10 \mathrm{c}$. ; per $1 / 4 \mathrm{lb}$. $25 \mathrm{c}$.; per $1 \mathrm{~b}$. $80 \mathrm{c}$.

Yellow Aberdeen, or Scoleh rellow.-This is a highy an proved CATTLE TURNIP attaining a large size. Pkts. 5c. and 10c, we oz. $10 \mathrm{c}$.; per $1 / 41 \mathrm{~b}$. $15 \mathrm{c}$.; per $1 \mathrm{~b} .50 \mathrm{c}$.

Prussian, Ixanower, Lomg French, Sweet German, Cho on Na vet.-Under all these names is to be recognized one and the
same variety of Turnip, cultivated exclusively for the table. Pkts. 5c. und same variety of Turnip, cultivated exclusively

Bloorasdale Swede, or IRuta Baga.-Thero aro probably fify so-called forms orvarieties of Purple-Top Ruta Baca, some quite similer: others widely differing. Tho BLOOMSDALE Is quite wonderful its its fine breeding. In nothing that vie offer ars the effects in selection and in careful breeding so apparent as in this Ruta Baga. It appears almost as a careful breoding so apparent as in this Ruta Baga. It appears almost as a plant of a distinct family, so far removed is is from the necky or tap-rootod English forms. The BLOOMSDALE is delicate in texturo, purple crowned, golden skinned, almost perfectly globular in form and eariier to mature of a rounded crown, the small rat.lail root terminating a symmetrical base. Nothimg like it can be seen among the English varieties. We havo had them over and over again. It cornpares with other Swedes as a wellbred short-horn cow compares with a scrub cow. The Bloomsdale Swede will be found for table uso during Winter, being of fine lexture and of fine favor. Pkts. $5 \mathrm{c}$. and $10 \mathrm{c}$; ; per oz. 10c.; per $\$-4$ !b. 20c.; per lb. $60 \mathrm{c}$.

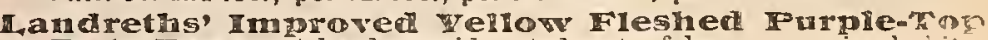

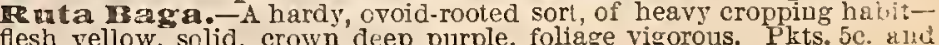
$10 \mathrm{c}$. ; per 0z. $10 \mathrm{c}$; ; per $1 / 1$ lb. $15 \mathrm{c}$.; per $1 \mathrm{~b} .40 \mathrm{c}$.

White Flesthed IPugple-T'op Ruta Baga.-This mainly differs from the Yellow Swede in interior color. For table use sume
families prefer it to the yellow, as milder, others prefer it because it is white, as contradistinguished from yellow. It possesses all the fond qualities of the jellow, and, when there is a preference for color, can be
recommended. The variety is hardier than the yellow. Pkts. $5 \mathrm{c}$. aud $10 \mathrm{c}$; per oz. $10 \mathrm{c}$.; per $1 / 4$ lb. $15 \mathrm{c}$.; per $1 \mathrm{~b} .50 \mathrm{c}$.

Chammion Svecie, or Yellow Ifuta Raga (IMPORTED).-A superior English-grown Ruta Baga, but not equal to the Bloomsdale Swede. Pkts. 5c. and 10c.; per 0z. 10c. ; per $1 / 41 \mathrm{lb} .15 \mathrm{c}$; ; per 1b. $40 \mathrm{c}$.

Dixie I,and.-A new form of Turnip for Winter Greens and also an ex. cellent root for table use. No variety producing tops so entirely proof
against frost. The foliage a deepblue greel, the root oval, smooth, white and tender; destined to supersede the Seven Top, being more hardy as productive of leaf for Winter Greens, with additional advantage of producper $1 \mathrm{~b} .60 \mathrm{c}$.

Bud10ng or Bread Stome. - A long-keep "lg Winter variety, remaining in perfect condition until late in the Spring. Flesh white, and in some respects similar to a White Ruta Baga, but having 2 T

Southeril Prize.-True strain of the favorite Turnip for Greens in Virginia and the Carolinas. Valued also for its bulb. Our stock is from seed obtained from the originator. Pkts. $5 \mathrm{c}$. and $10 \mathrm{c}$. ; per $0 \mathrm{z} .10 \mathrm{c}$; per $1 / 41 \mathrm{~b}$. $15 \mathrm{c}$. ; per $1 \mathrm{~b} .40 \mathrm{c}$.

SeverA-Top (FOR GREENS on SALADS).-This, the hardiest of all sorts, may be left standina in the open ground during Winter as far north as may be left standing in the open ground during winter as far north as
Philadclphia. In the Southern States it yields, in the Spring, ahundant foliage for bolling with cured meats, and is in much demand. Pkts. $5 \mathrm{c}$. and 10c. ; per oz. 10c.; per $1 / 4 \mathrm{lb}$. 15c.; per $1 \mathrm{~b}$. $40 \mathrm{c}$. 


\title{
POTATO.
}

PIRTES, day of nublication of this catalogue.

Solanum tuberosum-Pomme de Terrc-Sartofiel-Patatas Papa.

We here record our protest against the expression "Irish Potatoes" as applied to any of the many forms of round or Kiduey Po:atoes, the $T$ : : $"$ ? : $z$ \&

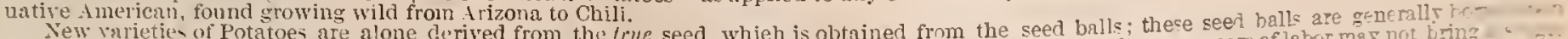
late varictice The development of truly valuable sort. It is, however, a matter of ehance, and the first experiment may develop a novelty of the highest merit.

\section{POTATO SEED.}

The Potato, as ordinarily propagated, is not grown from the seed, but from the tuber, a cutting of which resembles a graft or bud from a ates the good or bad qualities of the parent. The true seed which is borne in a seed-pod following the blossom, is very seldom tetn, is very di. eu, gather. and consequently is very expensive. In appearance resembles a Tomato seed of ahout one-tenth derelopment; the potaio te.urs.

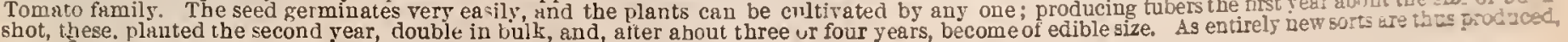
shot, these. planted the second year, double in bulk, and, after about
the cultivation is rery interesting and often profitable. Per plit. 30c.

TUBES. (Prices this day only, subject to fluctuation.)

ONE-AND-A-HALF BUSHELS OF EYES WILL PLANT 100 YARDS. OR AN ACRE WILL YIELD FROM :00 TO 400 BUSHELS.

Our stock of Potatoes, which we send out, has gained us much celebrity, for purity and good measure.

\section{BARIREIS.}

The harrels we ship in are round-hooped, full diameter and standard measure. Potatoes are cenerally sold in fat-hooped, straight-s.ded, under zkd are.s.

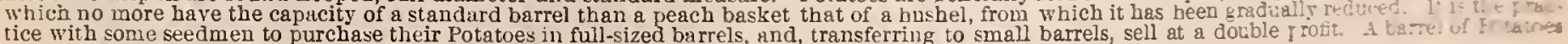
that does not weigh, wheu put up, 160 pounds net, is a traud, unless sold as a small barrel.

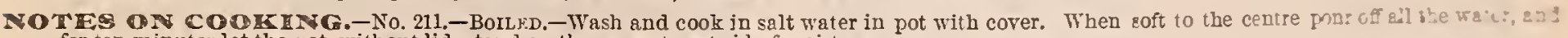
for ten minntes let the pot, without lid, stand ou the range to get rid of moisture.

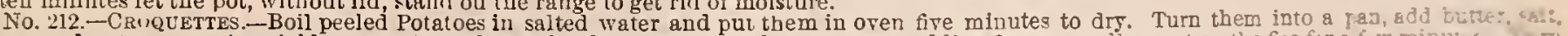

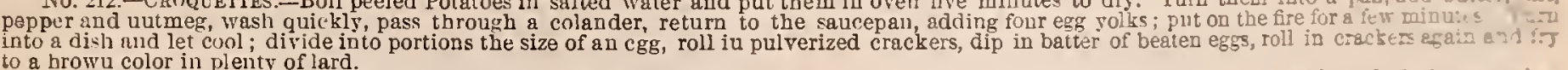
to a hrowu color in plenty of lard.

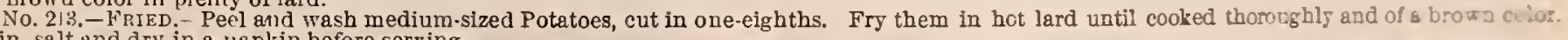
Drain, salt and dry in a

No. 214.-IN CREAM.-Tuke cold hoiled Potatoes, cut in small pieces, put in stewing pan with cream sauce, salt, pepper, antmeg and bure?, cars being taken not to make the sauce too thick.

No 215. - LYoNAISE-Cut cold boiled Potatoes in thin slices, put in frying pan, add butter, thin sliced onions, salt and pepres. Fr. Eerve with chopped Parsley.

No. 216.-STEWED.-Peel and slice cold bolled Potatoes, put in a saucepan with milk, butter, salt, pepper and nutmer and let boil. $\Delta$ dd Parslej ard butter, and mingle all well by tossing the saucepan until the sauce is creamy. Serve hot.

\section{THE ALLIANCE IS ONE OF OUR NEW POTATOES. Landreths', Farmers' Alliance.}

\begin{abstract}
our recommendations of the potatoes "garfield" and "STAte OF MAINE" WERE FULLY SUSTAINED BY PUBLIC VERDICT, AND THE DEMAND FOR THE TWO VARIETIES STILL CONTINUES. LAST YEAR WE INTRODUCED A NEW VARIETY, "LA N DRETHS' FARMERS' ALLIANCE," THE PRODUCER OF WHICH DESCRIBES IT AS FOLLOWS:
\end{abstract}

"This valuable new early Potato is from a hybridization of Landreths' State of Maine and the Early Vermont, and sfter four jean of tr.al rrores wo be one of the very earliest and most productive." "

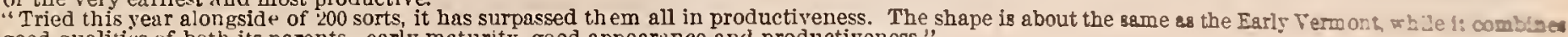
the good qualities of both its parents-early maturity, good appearunce and productiveness."

"The lesh is white anil fille grained ; it cooks dry and mealy and is of superior flavor."

"These admirable quaiities it has when frst dug, and retains them till late in the Spriag."

"The foliage is deep green in color, very vigorous."

"The tuber are borne in a compact buneh."

Per ?b. postpqid 25c.; per $1 / 4$ bush. $\$ 1.00$; per bush. $\$ 3.00$; yer bbl. $\$ 6.00$.

PRICES, day of publication of this Catalogue.

Early Ohlo. - This sort has a reputation as being very valuable because of its astonishing productiveness as a first early. In demand by market gardeners. Per bush. $\$ 1.75$; per barrel $\$ 4.50$.

Prince Edward Island Rose.-Very early and productive. Precerving the original character and quality of the Rose. Per bush. $\$ 1.75 ;$ per bbl. $\$ 1.50$.

Extra Early Vermont.-Same character as the Early Rose. Said to be somewhat earlier. Pcr bush. $\$ 1.75$; per bbl. $\$ 1.50$.

Mar1y reose.-A well known variety. Early, remarkably good flavor, solid, very productive, blush skin, white flesh; a very good keeper. Per bush. $\$ 1.75$; per bbl. $\$ 4.50$.

L, andreth', Farmers' Alliance.-Reports received from a host of plunters of this new Potato are to the effeet that. in vine it is of such healthy; in tuber it is a wonderful bearer of large, smooth, oblong, white- fleshed, sound Potatoes, resisting rot; in gualiy it is angly and bet flavored; in production it has prodaced serents to one. In the sout States fine seeond crops have been produced frum ins cor sed. pe: 1b. pestpaid, 25c.; per $1 / 4$ bush. $\$ 1.00$; per bush $\$ 3,0$; per

Peach Blow, Jr.-Absolutels norel; a hrtwid berween the fam old Peach Blow and Irish Kopp. Exceedingly earty ; esth pure of th (SOLD OUT.)

Golden Harvest. - A new hybrid between the fose add lich snow white. Unexeelled for table either when halr of sin gllteg. fectly mature. A good keeper. Perlb. postpais, dic. pern when th-

Charles Downing. - A new seedling of saperior oualirs sol exomet ingly early. Strong in vine, large producer, croint gasteced iolex new rarjety in the market. Per hush of rare cooking gualitr. The buse

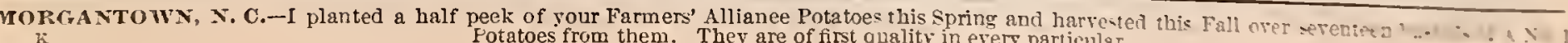




\section{POT ATO-CONTINUED.}

PRICI:S, day of publication of this catalogue.

I.and retiss, Garfield (NEw).-A sechling of Farly Vermont hybridizal with Excelsior. In form flattened, resembling the first, and in quality and crisur the second. Later than the Vermont, larger and more productive. Vines stocky, tubers produced clusely about the root and muiformly large. Tubers, when raw, without excess of moisture, iudicating frecdom from a soggy character. Starcliy qualitics strongly developed Tuber. when cooked, pure white, fine grained, mealy and extraordinarily finc. As a market variety it is very showy, supcrior to extraordinarily finc. As a narket varicty it is very showy, supcrior to weighiug from one and a half to two pounds. Per bush. 82.00 ; per bbl. $\$ 5.00$.

Daildreting' State of Braine (NEW).-Resulting from the impregnation of the early Vermont by pollen from the Peerless, the cross combining the desirable features of medium size forn cylindrical, slightly elongated; the flesil snow white and crystaliine or mealy; the flavor nutty aud unsurpassed. The vine erect in growth, with glossy leaf, not attractive to bugs. Tubers spread out in the hill like those of the Farly Vermont; medium early. Per bush. $\$ 2.00$; per bbl. $\$ 5.00$.
Green MIoullain.-Ninety-four fold have been produced, or 235 bushels from two aud a half bushels planted. 'This Potato possesses many good qualities, among which may be specially noted its power of resistance to drought, its productiveness of tubers of uniform size and appearance, its thrift on poor soil without much fertilization, its freedon from disease before digging and freedom from rot in the cellar, its admir. able keeping qualities till new crop Potatoes succeed it. I'er bush. $\$ 2.00 ;$ per bbl. $\$ 5.00$.

Dalsol Redi.-Large, long and wedge shaped. Thrives well on eithex sandy or clay soils. Tastes much like the Peach Blow; solia, mealy and fine graiued. Enormous yields are reported of this variety. Per bush $\$ 1.75$ : per bbl. $\$ 4.50$.

Burbank's Seedilng.-Per bush. \$1.75; per bbl. \$4.50.

Peerless. - An excelient Potato for general crop. Large size, very pro ductive, good quality. white skin and flesh. Pcr bush. \$1.75; per bbi. $\$ 1.50$

Snowflalke.-Medium early, very productive, pure white flesh, mos. and goud flavor. Per bush. $\$ 1.75$; per bul. $\$ 4.50$.

IVIannoth Pear1.-Per bush. $\$ 1.75$; per bbl. $\$ 4.54$

\section{SWEET POTATOES.}

Convolvulus Batatis.

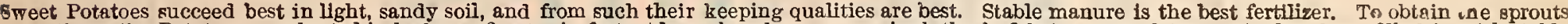

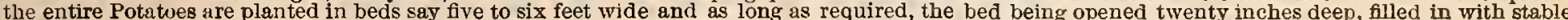

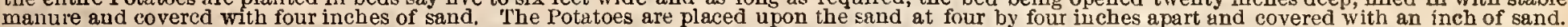

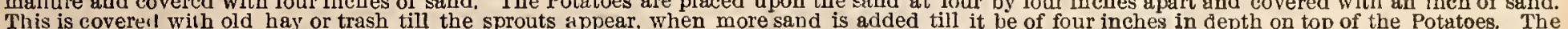

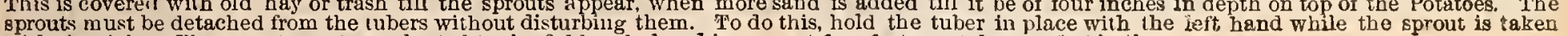
with the right. The sprouts are transplanted to the field and placed in rows at four feet apart, by two feet in the rozs.

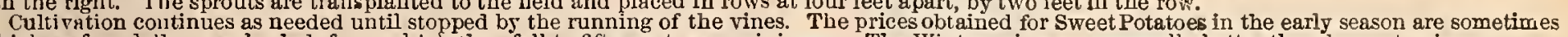
as high as four dollars per bushel, from which they fall to fifty cents as a minimum. The Winter prices are generally better than harvest prices.

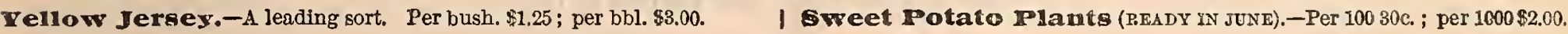

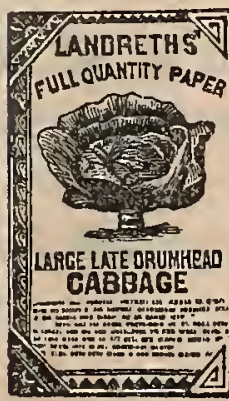

\section{Trial Packets for Gardeners.}

It is the function of the seedsman to keep up the standard of old, well-tried varieties of vegetable seeds, and establish on a firm basis any improvements, or new sorts, before offering them to his patrons. Yet from the endless list of varieties offered in seed catalogues, and through the resulting disappointment where seedsmen have ignored the importance of the matter above referred to, gar deners, as a rule, are not prone to make experimeuts, but prefer adhering to the sorts they customarily plant. This, however, should not be so; and in order, therefore. that the experienced and progressive gardener may acquaint himself with THE BEST AND MOST YROFITABLE THAT IS PRODUCED, we give him the benefit of our own experience in culling, and leave for him the simple task of deciding practically on the merits of our selection. We have concluded to offer Fon TRIAL oNLY, at the nominal price of two cents per packet (postage free), small sample packets of the choicest vegetable seeds, by groups. These groups will not be brokeu. For example, gardener wishing to test the comparative merits of First Early Cabbage, would purchase group No. 8 , consisting of ten distinct packets of varieties after our catalogue, and costing twenty cents for the entire group. We suggest that a small patch of the garden be set aside as varieties after our catalogue, and costing twenty cents for the entire group. We suggest that a small patch of the garden be set aside as
a trial ground, where the varieties can be grown side by side, or in the same rows and compared. To the gardcner nothing could be a trial ground, where the varieties can be grown

Gardeners, Truckers and Private Families having their own gardens should not fail to avail themselves of this opportanity.

\section{LIST OF GROUPS.}

CAN BE ORDERED BY SIMPLY NAMING THE NUMBER OPPOSITE EACH.

\begin{tabular}{|c|c|c|c|c|c|c|c|c|c|c|c|}
\hline Group. & r & $\begin{array}{l}\text { No. of } \\
\text { Varie- } \\
\text { ties. }\end{array}$ & $\begin{array}{l}\text { Price } \\
\text { of } \\
\text { Group. }\end{array}$ & Group. & & $\begin{array}{l}\text { No. of } \\
\text { Varie- } \\
\text { ties. }\end{array}$ & $\begin{array}{l}\text { Price } \\
\text { of } \\
\text { Group. }\end{array}$ & Group. & & $\begin{array}{l}\text { No. of } \\
\text { Varie- } \\
\text { ties. }\end{array}$ & $\begin{array}{l}\text { Price } \\
\text { of } \\
\text { Group }\end{array}$ \\
\hline \multirow{14}{*}{ 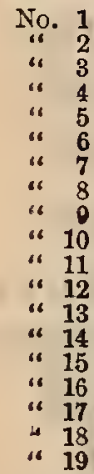 } & \multirow{14}{*}{ 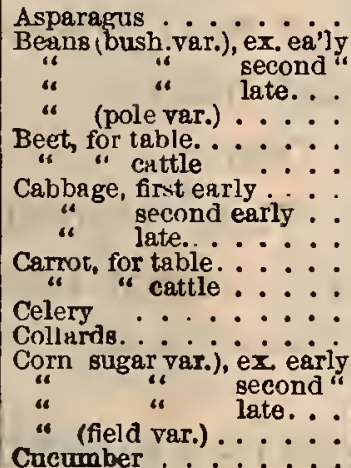 } & \multirow{14}{*}{$\begin{array}{r}2 \\
4 \\
6 \\
4 \\
8 \\
10 \\
6 \\
10 \\
10 \\
8 \\
6 \\
3 \\
6 \\
3 \\
4 \\
4 \\
3 \\
6 \\
6\end{array}$} & \multirow{14}{*}{$\begin{array}{l}.04 \\
.08 \\
.12 \\
.08 \\
.16 \\
.20 \\
.12 \\
.20 \\
.20 \\
.16 \\
.12 \\
.06 \\
.12 \\
.06 \\
.08 \\
.08 \\
.06 \\
.12 \\
.12\end{array}$} & \multirow{14}{*}{$\begin{array}{ll}\text { No. } 20 \\
\text { “ } 21 \\
\text { “ } 22 \\
\text { “ } 23 \\
\text { “ } 24 \\
\text { “ } 25 \\
\text { “ } 27 \\
\text { “ } 28 \\
\text { “ } 29 \\
\text { “ } 30 \\
\text { “ } 31 \\
\text { “ } 33 \\
\text { “ } & 34 \\
\text { “ } & 35 \\
\text { “ } & 36 \\
\text { “ } & 38\end{array}$} & \multirow{14}{*}{ 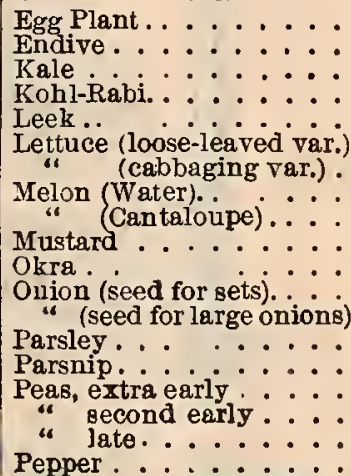 } & \multirow{14}{*}{$\begin{array}{r}2 \\
3 \\
3 \\
5 \\
2 \\
2 \\
6 \\
15 \\
10 \\
15 \\
3 \\
3 \\
8 \\
8 \\
2 \\
2 \\
3 \\
6 \\
6 \\
4\end{array}$} & \multirow{14}{*}{$\begin{array}{l}.04 \\
.06 \\
.10 \\
.04 \\
.04 \\
.12 \\
.30 \\
.20 \\
.30 \\
.06 \\
.06 \\
.16 \\
.16 \\
.04 \\
.04 \\
.06 \\
.12 \\
.12 \\
.08\end{array}$} & \multirow{14}{*}{$\begin{array}{ll}\text { No. } & 39 \\
\text { “ } & 40 \\
& \mathbf{4 1} \\
\text { “ } & 42 \\
\text { “ } & 43 \\
\text { “ } & 44 \\
\text { “ } & 45 \\
\text { "6 } & 47 \\
\text { " } & 48 \\
\text { “ } & 49 \\
\text { “ } & 50 \\
\text { “ }\end{array}$} & \multirow{14}{*}{ 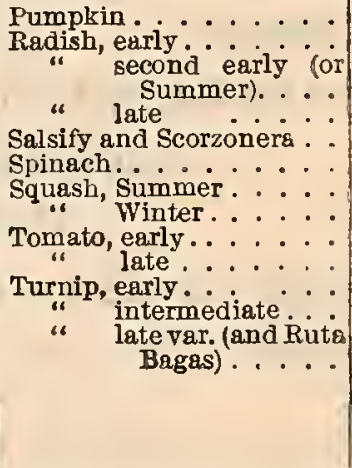 } & 3 & .06 \\
\hline & & & & & & & & & & 10 & .20 \\
\hline & & & & & & & & & & 4 & .08 \\
\hline & & & & & & & & & & & \\
\hline & & & & & & & & & & 3 & \\
\hline & & & & & & & & & & $\begin{array}{l}4 \\
6\end{array}$ & \\
\hline & & & & & & & & & & 6 & \\
\hline & & & & & & & & & & & \\
\hline & & & & & & & & & & $\begin{array}{l}6 \\
6\end{array}$ & \\
\hline & & & & & & & & & & & \\
\hline & & & & & & & & & & 4 & .06 \\
\hline & & & & & & & & & & & 55.64 \\
\hline & & & & & & & & & & & \\
\hline & & & & & & & & & & & \\
\hline
\end{tabular}

OR WE WILL SUPPLY THE ENTIRE LIST OF 282 PACKETS (VALUED AT \$5.64) FOR FIVE DOLLARS, POSTPAID.

NASSAU, WEST INDIES.-Your seed gives universal satisfaction. My customers are loud in their praise. Being mysclf a gardener, I can also gir personal testimony. 


\section{The "A B C of GARdening,"}

Arnounced for publication lası year, was unavoidably delayed. The scope of the work has been enlarged and the title changed to
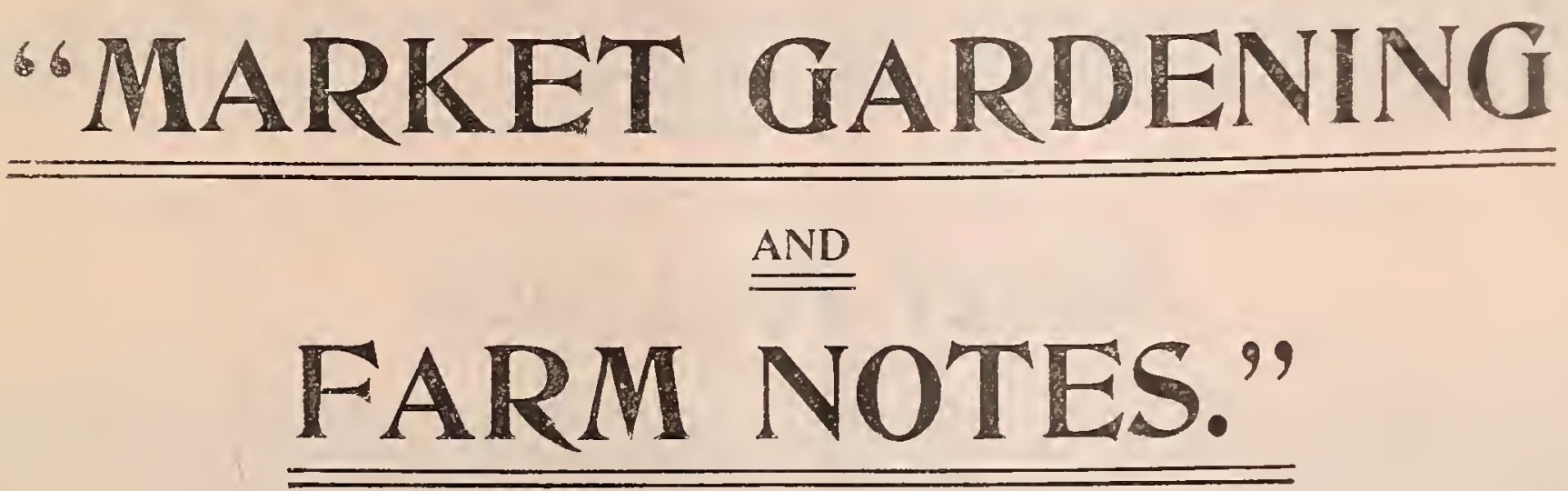

BY BURNET LANDRETH.

This book will be ready for distribution about ist of January, I893. Its price will be $\$ 1.00$ per copy, postpaid. It will contain about thirty chapters on the following and other subjects:

Market Gardening.

Location and Soils.

Science of Gardening.

Chemistry of the Garden.

Stable Manure, Compost and Com-

mercial Fertilizers.

Sowing Seeds, Germination.

Transplantation.

Succession or Rotation.

Garden Insects.

Diseases of Garden Vegetables.

ORDERS FOR THE BOOK ARE NOW BEING REGISTERED.

\section{DO YOU NOT WANT ONE?}

Heredity in Plants.

Saving Seeds.

Seedsmen's Novelties.

Seedsmen's Responsibilities. Hotbeds and Cold Boxes.

Market Gardening under Glass.

Packing and Shipping.

Vegetable Garden Calendars.

Vegetable Diet.

Notes and Queries. Plant Nutrition.

Rural Traditions. Root Culture. 


\section{SUCCESTIVE PRICES FOR}

\section{Grass, Field and Agricultural Seeds, and Sundries.}

THESE PRICES CONSTANTLY SUBJECT TO FLUCTUATIONS-THEREFORE, MERELY SUGGESTIVE.

[ख If you do not see what you want, ask your merchant to write to us about it, or you drop us a postal card.

\section{LATEST QUOT'ATIONS PROMPTLY GIVEN UPON APPIICATICD.}

BARLEY.

Two-rowed ............................. per bush. $\$ 150$ BELLOWS AND ATOMIZERS.

Allen's, $\$ 2.25$. Hammond's, large, $\$ 2.00$; small, $\$ 1.25$. Woodason's, double cone, $\$ 3.50$; single cone, $\$ 1.00$. Houchin, nickel-plated, No. 19,80 cts.; No. 16,65 cts.; No. 14,60 cts.; No. 11,55 cts.; No. 9 50 cts. Inseet Powder Gun, large, 20 cts.; small, 12 cts.; Paris Green Sifter, 20 cts. Paris Green'Sifter, Peck's, 60 cts. Water Bellows, $\$ 2.00$.

\section{BIRD SEED, \&C.}

Canary Bird Seed Mixed . . . . . . . . . . per bush. \$4.50; per lb. 10 We offer ORIGINAL SEALED PACKAGES OF MIXED BIRD SEED at 10 cents per pound. Postage 8 cents extra, if sent by mail.

The packages contain a mixture of Canary. Hemp, Nillet and Rape Seed. The combillation of these feeding substances will be found to be in correct proportion and to comprise everything necessary to the sustenance of Cage Birds. Bird seeds in thrse packages have proved to be acceptable to owners of valuable Birds, many of which are injured by the fceding of foul, fermented or dusty seeds.

Canary Seed Unmixed . . . . . . . per bush. $\$ 1.50 ;$ per $1 \mathrm{~b} .10$ Bird Millet. . . . . . . . . . . . . . . pel bush. $\$ 1.60$; per pt. 05 Bird Tonic . . . . . . . . . . . . . . . . . per bottle, 25 Cuttle-fish Bone. . . . . . . . . . . . . . . . . . per lb. 40 German Summer Rape. . . . . . . . . . per bush. $\$ 1.50$; per pt. 10 Hemp Seed . . . . . . . . . . . per bush. $\$ 2.25$; per pt. 08 Lettuce Seed. . . . . . . . . . . . . . . . per 1h. 25

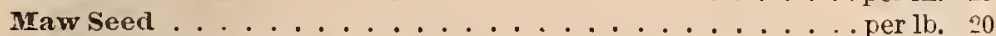
Mocking-Bird Food (screw-top bottle) . . . . . . . . per bottle, 20 Song Restorer . . . . . . . . . . . . . . per bottle, 20 Unhulled Rice for Java Sparrows . . . . . per bush. $\$ 3.00$; per pt. 10 BROOM CORN.

Erergreen . . . . . . . . . . . per bush. $\$ 2.50$ : per qt. 20 BUCKWHEAT.

Silver Hull, Pure . . . . . . . . . . . . per bush. \$1.30; per qt. 10 Common. . . . . . . . . . . . . . . . per bush. \$1.:5; per qt. 10 Japanese. . . . . . . . . . . . . . . per bush. $\$ 1.25$; per qt. 10 Ornamental.

\section{CASTOR BEANS.}

\section{CLOVERS.}

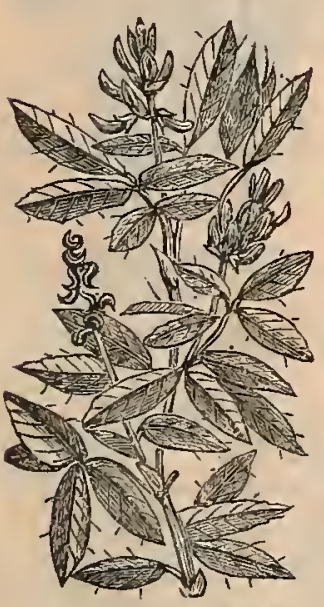

LUCERNE OR ALFALFA.

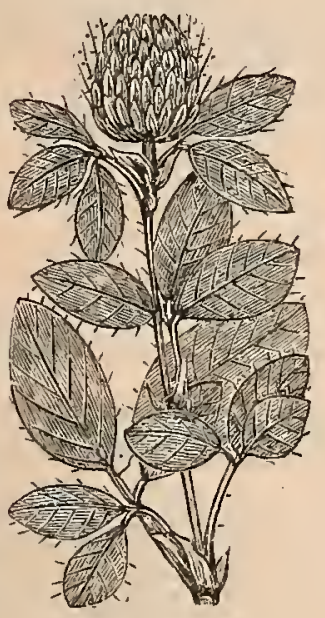

RED CLOVER.

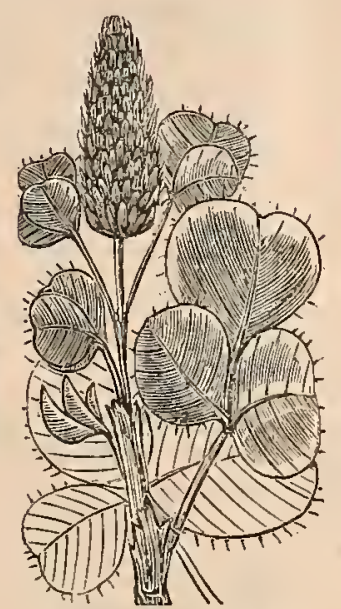

SCARLET CLOVER.

\section{CLOVERS.}

Alsike Clover (TRIFolium HYBRIDUM).-The earliest large Cloyer. Pussibly a liybrid between the Red and White, possessing qualities comnon to both; productive, sweet, permancnt, extrem ely valuable boti
for pasturage or soiling. Clover-sick latuls will sometimes produce fine crops of Alwill sometimes produce fine crops of A!-
sike, which lands, after three rears in Alsike, and an intermediate graill crop, Aill again produce Red Clover. The flowwill again produce Red Clover. The flow-
ers are a distinct light pink, and aftord fine pasturage for bees. This clover seeds itself freely the first year. Sow $12 \mathrm{lbs}$ to the acre............. per lb. 25

Giant Sain Foin (ONOBRychIS SATIVA).This (not a clover), in some sections, is an importaut forage plant, producing an immense quantity of green food, and, unde favorable conditious, large crops of llay. It requires a calcareous soil aud will not succeed worth of the Potomac or Olio.
The seeds are of high value as food for

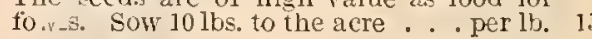

ALSIKE CLOVER.

Japan Clover (LESPEDEZA STRIATA). per ll

Lucerne or Alfalfa (MEdicago SATIVA).-One of the most valuable among the Clo rers. Staudiug for years, shooting its roots downward till they are ten to fiftcen feet below the surface, it resists the dricst weather, and, when every blade of grass droops for want of moisture, it holds up fresh and green as in genial Spring. It does not succeer on compact clay nor on land with impermeable subsoil. Far from exhausting land, it increases fertility, as has beeu fully establisbed Sow $10 \mathrm{lbs}$, to the acre.

Red Clover (Trifolium PRAtense).-This is the most widely cultivater of all the pasturage plants: loosening the soil and admitting the air and drawing up and storing away near the surface the valuable principles scattered in the earth beueath, it is regarded as one of the best of vegetable fertilizers, as well as a cattle food of highest merit. Its luxuriaut foliage, by shade, increases the fertility of the earth and smothers noxious weeds. It is a lime plant aud does best on stift loams. Its habit of growth is rapid, and, though naturally a bienniai, loams. Its habit of growth is rapid, and, though naturally a bienniai, may, by close pasturage, be made to last three or more years. Sow,
in Autumn, south of the Potonac or Ohio, and in Spring in Northern States. Sow 16 pounds to the acre. . . per hush. $\left(60 \mathrm{lbs}\right.$.) ws. $^{25}$; per gt. 40

Red Clorer, Mammoth.

..... per bush. $(60$ lhs.) $\$ 9.00$; per qt. 45

Scarlet Clover (TRIFOLIUM INCARNATUM) The most beautiful of all clovers, readily distinguished by the bright crimsou color of its flowers. Exceedingly productive and very palatable to cattle. it is the latest of all the clover family, and thus affords a desirable succession of green food. At present in much demand in the South, where it has proved valuable. Sow $10 \mathrm{lbs}$. to the acre.

White Dutch Clover (TrIFolida RePENS). Not a heavy producer of hay, but iuvaluable in permanent pastures. Will grow on any soil, but luxuriates in damp location and in damp seavolls. It is very persistent in growth on rich soils, affording rare feed, but on thin soils will not suceecd. Sow 12 lbs. to the acrc.

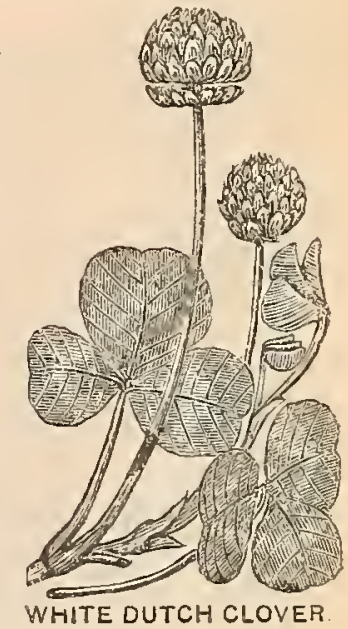

Postage extra. On Peas and Beaus 16 cents per quart, and Corn 15 cents per quart; other Small Seeds 8 ceuts per lb. Quarter pouud and under, anr $t 5$ and 10 cent Flat Papers, Free of Postage. 


\section{COTTON.}

We will not altempt a description of the Cotton plant or its varieties, but be satisfed to simply announce that wc have for sale the foliowing varieties, which we oficr at attached prices:

Extra Early Caroliua . . . . . . . . . per bush. $\$ 4.25$; per $1 \mathrm{~b}$. $\$ 035$ sea Island. . . . . . . . . . . . . . per bush. $\$ 1.50 ;$ per lb. 20

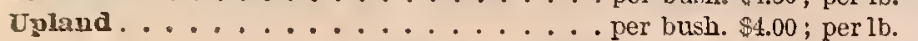

\section{FERTILIZERS.}

Button Bone Mreal, finc, per ton, $\$ 42.00$; per $100 \mathrm{lbs}$. $\$ 2.25$; per 5 -1b. bas Bazugh's \$25.00 P'hospliate ..... per ton, \$15.00; per bag, 200 lbs, 275 Boker's Food for lowers . . . . per pkge. small 1zc.; per pkge. large Cotton Seediseal ......... . per ton, $\$ 35.00$; per 100 lbs. 200

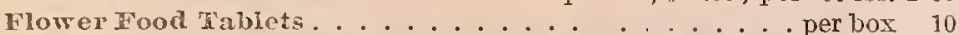
Ground Rone per tou, $\$ 32.00$; per bag, 200 lbs. $\$ 3.50$; per bag, 50 lbs. 1 is Guano, Ammoniated. . perton, $\$ 50.00$; per bag, 100 lbs. $\$ 3.25 ; 1-1 \mathrm{~b}$. box 10 Landreths' Lawn Fertilizer.

Nito . per ton, $\$ 50.00$; per bag, 100 lbs. $\$ 3.00$; per bag, 5 lbs Peat, Jersey $\ldots \ldots \ldots \ldots$. . . . . . per bbl. $\$ 1.25$; per bush. Sulphate of Potas . . . . . . . . . . . . . per 1b. Swiftsure super piosphate. . . . . . per ton, $\$ 35.00$; per bag, 200 lbs. 400 Wood Ashes . . . . . . . . . . . . . . . per bbl. 250

\section{FLAX S.EED.}

The finest Flax produeed in Europe is growu near Courtrai, in Western Belgium. The leading features which go to make up the superior quality of this Flax are the composition of the water of the River Lys, rotation of crops, fertilizing, skillful manipulatiou aud the ase of choice seed. The seeds used are either Riga, or stock growi from it and but one year removed, the amount of seed to the acre ranging from $1 \%$ io $31 \%$ bushels. To have good Flax the crop must. be harvested bcfore the seed is ripe; thus Flax-growing for fibre and Flaxgrowing for seed are two distinct systems . . . per bush. \$2.75; per qt.

CRAFING WAX. Per lb. 30c.
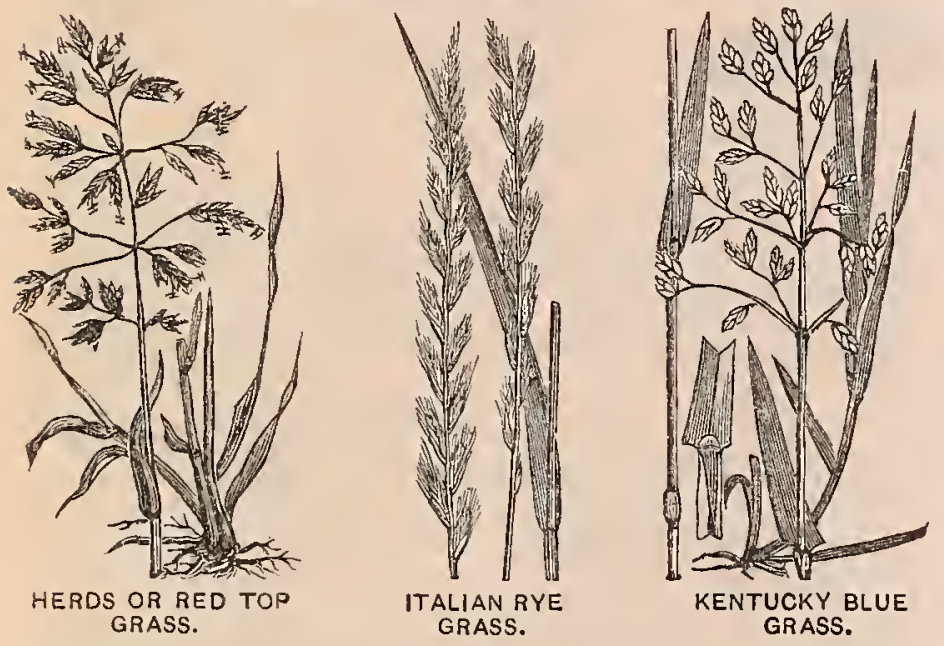

GRASS SEFD.

Bermuda Grass . . . . . . . . . . . . . per $1 b .125$

Herds, or Red Top Grass (AGRostis vulGARIs). - A good perennial Grass, generally sown on permanent pastures. It succeeds Clover and Timothy when they have died out. Does well on any soil, but best in moist land. If kept fed down close it is a good forage plant, but allowed to become rank it is wiry and innutritious. Sow $20 \mathrm{lbs}$. to the acre. . . . . . . per sack ( $50 \mathrm{lbs}$.) $\$ 3.00$; per bush. (of $10 \mathrm{lbs}$.)

Hungarian Grass (PANICUM HUNGARIENSTS).-An annual forage pIant of celebrity. It germinates rcadily and withstands drought. It has mumerous succulent leaves, broad and over a foot in length, the plant, in strong soil, reachiug a height of three feet. Cut early it makes an Sorv a bushel to the acre. . . . . . . . . . . per bush. \$1.50; per qt.

Italian Rye Grass (LoLIUM ITALICUM).-This is a variation of the Perennial Rye Grass, beiug earlier and more rapid in growth, proas durable. It shoots less and is a stronger feeder, enduring any am durable. It shoots less and is a stronger feeder, enduring any such, is the best grass for soiling, affording repeated luxuriant and natritinus crops. It is not suited for p $\bullet$ rmanent pastures, for, though making a splendid appearance for one or two years, it then dies and leaves the land bare having smothered out all other Grasses Its strong germinative power, its rapid development, its luxuriant herbage, its hardy habit, its nutritive qualities, all point tr it as a valua.
ble grass. Sow 25 lbs, to the acre . . . . . per bush. (20 lbs.) 25 For additional hints on Grasses, see Introduction, page $i$.

Jolnson Grass . . . . . . . . . . . . . . . . Wtr lb. \$o

Tentucky Blue Grass (POA PRATENSIS). - This is a pasture Grass of high merit, the earliest to start in Spring and continuing green be recornWinter. Though it makes fine quality hay, it is not to be recomth mended for that purpose, beiug a light cropper. Its nniform grow and its beantiful habit and color make it desirable quires more time than other Grasses to become establshed, in limestone land. $=12$ longest living of all. It flourishes best in limestone $\$$.

TANDRETHS' MIXED LA W W GRASS. - We offer mizej Lawn Grase Seed in sealed packages of One Pound, Half Pound and Quime Pound. The mixture contains those varieties which long prarsteal experience has prored to be the best adapted for soil. In gental. The seeds used are clean and full of vitality, and all persors [l-ing thcin will be certain, provided there be sufficient rainfall, to secture 8 stand of grass both of delicate texture and of durabilitr. The ceased quoting Lawn Grass by the bushel of and never can be a "busher to the salculate the price for the oud fictitious bushel. No extra charge for packages.

For Surface Efiect.

For Athletic Grounds of Lawn Jiaking, etc., see page

Meadow Fescue Grass. - A perennial grass of good quality: emTs s ell

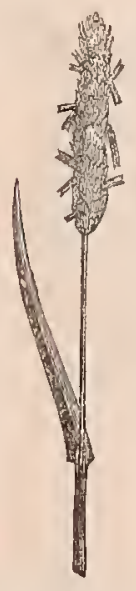

MEADOW FOXTAIL GRASS.
Has round smooth stems, tw

mountain lands of Virginia sath The numerous fibrous roots penetr to fifteen inches; makes goor has pasture, especially in the South. acre, broadcest Neanow Foxtail /ALOPECLRTS PPATEIST , $-\lambda$ ST, pereunial of high faror in Europe, one Habit e res ut suitable for park purpore?. Sureceeds by

drainud, rich loamy or clayer

hay and should be included in all perma: eat ret nes Sow 15 lbs. to the acre.

Meadow Oat Grass.

pe: It. 3

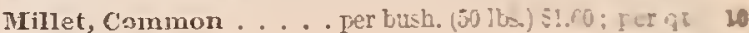

Millet, Cat-tail or Pearl. . . . . . . . . . ll 30

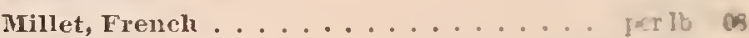

Willet, German (PANICTY GERMANCTM), This is an im. provement on Hungarian frass if cat just as the lease

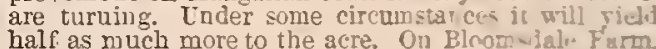
ou one occasion. we eut thirteen tons of rify, rleart has from three acres. Sow 1 bush. to the gan, I tu bu

Orchard Grass, or Rough Corksfoot (DACTI LIS GLOYERAT I) - ODe of the most valuable of all the cultirated Graves, bloomin w $^{\circ}$ h the Red Clover and making with it au admirable har. As a I has are Grass it is more productive than any other and does best under close feeding. It stands drought better than any other grass, are dried up. In summer it will gross are dried up. In Summer it will grow a week. It is disposed to grow in tussocks; a good preparation of the land and uniform and liberal seeding is a good preventise. All kinds of st ck aro fond of it, and it yields an enormous quautity of hay of superior quality. It succeeds well in ans soil, doing especially well in moist places Sow 2 bush. tu the acre. . . per bush. si so

Pasture Grass (READY MrTF.D).--The preps. ration of the land for Permauert Pastures is a labor that must not be slighted, and though farm work camnot be reduced to the nicety of Iawn Culture, we nerertheless direct attention to our directions on Lawn making, and would sar that the nearer the directions are followed the greater the probability of success it mul greater the probability of success. It must, 1 howerer, be borne in miud that a pisture sod cannot be obtained in one rear. $11 \mathrm{e}$ are prepared to furnish single grasses. or

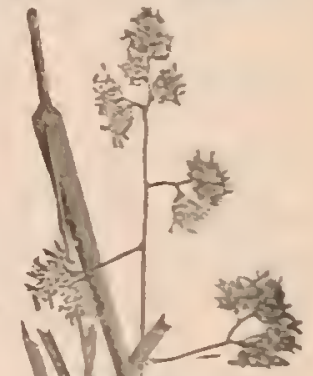

quirements of any ordinarr farm land for the prodoction $f$ hart of if permanent pasiure is desired, we are prepand to rum

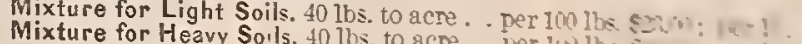
See Remarks on Pasturage (iraves lul lbs.

Perennial Rye Grass (Lourys PERENe

jest farmers of England. Leaves long. narrors and fine-br s ache the blossom it makes fine hayand abundant's bur fine (un 1 ib the no It requires a moist climate, and, in such, stands for equl wo unchant. Perennial Rje Grass will resist orerfor and for six cr wed rens banks, as its roots are rery fibrous gn and

banks, as its roots are rery fibrous and mat.lite

Timothy and Blue Grass in proner proporion is combination possessing the chief merits of an is prevering : f - hes

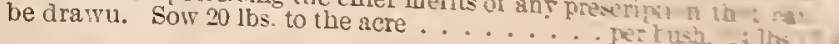

(n)

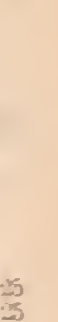
(n) 
Rescue Grass .................. per lb. $\$ 030$ Sheep's Fescue Grass ................ per lb. 12 Sweet Scented Vernal Grass, Annual.-A cheap imitation of Perennial and of no value comparatively ........... per lb. 13

Swect Seented Vermal Grass, Perennial (Antuoxantuom odoraTUM1). - One of the earliest in Spring and latest in Autumn. It is almost the only Grass that is fragrant, and to its presence our liay fields owe much of their charm. It has little nutritions properties in itself', but it is well known that on pasturages where it abounds the finest nintton is produced. It does best on light luams and medum sands, but dies out on black pratrie soil. Sow 20 lbs. tu the acre if sowa aione, per $1 \mathrm{~b}$.

Teosinte . per oz. 15c.; per lb. 125

Texas Bluc Grass. - This does viell in the ciulf states, where by thany it is considered superior to Kentucky Blue Griss. Once established in a tavorite situatiou it berom situatiou it becomes permauent

Mimotly (Phleum PRatense).As a crass to eut for hay this is unsurpasserl. It is coarse if allowed to ripen seed, but if cut in the bloum is bright and bighly nutritions. If sown with clover: as is often practieed, it has to be cut before full development, being later, and thus there is a loss in returils. It does best on loany

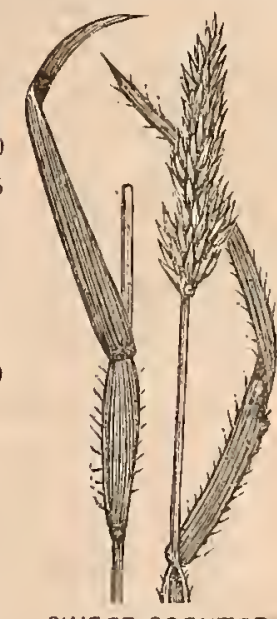

SWEET-SCENTED VERNAL GRASS.

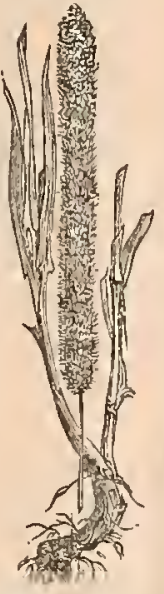

TIMOTHY.

soils. It is a large producer, two or three tons of bay being frequently made: the aftermath is, however, light. It is keeuly relished by ail stock, cspecially horses, and is generall w more free from dust than stock, cspecially horses, and is generally more free
uther hays. Sow to the acre, if sown alone, 10 lbs.

other hays. Sow to the acre, if sown alone, 10 lbs.

Wood Meadow Grass....................... per 1b 30

\section{HOTBED CLOTH.}

Medium . . per yard, 10c.; heavs, per yard, 13c. ; extra heavy, per yard 20

\section{INSECTICIDES.}

(SEE A LSO SOAPS.)

Carbolic Powder . . . . . . . . . . . . per lb. 10 Hellebore, White Powdered . . . . . . 1/4 lb. 10c.; 1/2 lb. 15c.; lb. 25 London Purple Insect Powder . . . . . . . . . . . . . per 1b. 20 Paris Green Insect Powder, in 1, 2, 3, 4 and $5 \mathrm{lb}$. cans . . . . per lb. so Persian Insect Powder . . . . . . . . per bottle, 1je.; per lb. 40 Slug Slot. . . . . . . . . . per $100 \mathrm{lbs} . \$ 1.00 ; 5$-1b. package 25 Thymo-Cresol, or Sheep Dip. . . . . per gal. $\$ 2.00$; per $1 / 2$ gal. $\$ 1.25$. per qt. 75c.; 8-oz. bottles 50c.; 4-oz. bottles. . . . . . . . . 25

Tobacco Dust . . . . . . . . . . . . . . per 1b. 05

Tobaceo Stems ............................. 03

\section{JUTE.}

We offer seed direet from India, and believe this plant can be profitably grown for fibre purposes so soon as a practieal machine can be built to strip off the bark. We have suecessfully grown Jute upon Bloomsdale Farm. and are much impressed with its vigorous ehareter and the ease with whieb its bark is stripped ; even more readily thau the bark of Ramie.

\section{LUPIN.}

White ............................... ber bush. 600 Yellow.

\section{MOLE TRAPB.}

Wrought Iron. . . . . . . . . . . . . . eaeh 30

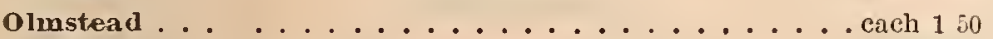

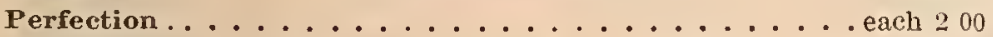
MUSHROOM SPAWN.

In bricks............................... per lb. 10

\section{NEST EGGS.}

Wainwright's Medicated ............ doz. 30c.; each 0 . Porcelain.................. doz. 30c.; cach 03 Woodward's Medicated . . . . . . . . . . . . doz. 40c.; caeh 05

\section{OATS}

Probsteier.-A fine White Oat. Yields well and stands up well; grain full, long, with thin hull ............ per bush. \$1 00

Russian Whitc.-One of tile best. A strong grower and good cropper highly reconmended as showy and protitable . . . . . per busb. 110

Surprise per bush. 100

Sonthern Winter.-For twenty-fire years we have been growing this very hardy productire Oat exteusively on our Virginia plantation. No other variety tested there edil compare with it. In virginia we sow it from September 15 to November 15 ; pasture it during 1 inter and cut from it a greater number of pounds of grain than any other Uat will produce in that section. A prodnction of 60 bushels of exceedingly heavy grain to the acre is not nneommon. The grain is dark, evidently remotely derived from a black-hulled vajety. We have sown this Oat on our Bloonsdale, Pennsilvanta, Farm in the month of March, and have eut 60 bushels in September.

March, and have eut 60 bushels in September.

Texas Rust Proof

per bush. 125

Weleomc.-A White Oat, introdnced fire years ago. Early, heavy and produetire; strong straw, growing five to six feet high, and making large stouls; said to have yielded as much as 97 bushels to the acre. per bush, 100

Vhite Belgian -A remarkably heavy and productive white Oat, attractive in appearance and iu every way most desirable. Ten days ahead of most other varieties, and therefore ripening at a more con-

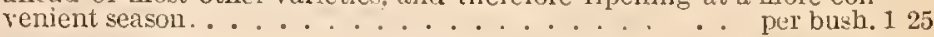

Wide-1wake Oats. - Arerage height, four to six feet; straw suffeiently strong and firm to prevent "lodging." Arerage vield, 65 to 90 bushels pir acre, aecording to the nature and condition of the soil. Graiu heavy and plump, having large meat and thin husk. The hardiness and rigor ol this variery is said to be in excess of that of any other known sort, while the tendency to rust is greatly diminished Thoroughly tested with all the leading varieties of this eomm. try, it is reported to bave proved itsell very superior. . . . per bush. 125

\section{OSAGE ORANGE.}

For Hedges................ per lb. $40 \mathrm{c}$; per bush. 9 E0

\section{PEAS.}

(FIELD VAHIETIES.)

Sown for plowing in as Green Manures. Vcry valuable fertilizers.

Canada Field

Cow Peas or Sonthem Black Eye

. per busli. 175

\section{PLANTS (In Season)}

(SEL ALSO ROOTS.)

Fixed priees given on application, and full remittance required Shipment at purchaser's risk, upon three days' notice. We will not ship plants C. O. D.

Cabbage Plants, Celery. Egra Plant, Pepper, Tomato, Raspberry, Strawberry, Hlackberry, Grape Vine.

\section{POP CORN.}

Ordinary . . . . . . . . . . . . . . p per $1 b_{b} 0^{-}$ Rice $\ldots \ldots \ldots \ldots \ldots$ per $l b . \ldots \ldots$

\section{POTATOES.}

(FOR DESCRIPTIONS, SEE PAGES aS, 39.)

Burluank's Secdling. . . . . . . . . . . per bbl. \$4.50; per busb. 175 Charles Downing. . . . . . . . . . . . per bbl. \$5.00; per bush. 200 Dakota Red . . . . . . . . . . . per b!). \$4.50; per bush. 1 ; Early Rose . . . . . . . . . . . . per bbl. $\$ 1.50 ;$ per bush. 175 Early Ohio.-Host productive early sort. . . . per bbl. \$1.50; yer bush. 175 Extra Eariy Vermont . . . . . . . . per bul. \$1.50 ; per bush. 175 I.andreths' Farmers' Alliance . . per lb. postpaid, 25e.; per peek, $\$ 1.00$; per bush. $\$ 3.00$; per bbl. $\$ 6.00$. (See description, page 38.)

Landreths' Garfield . . . . . . . . per bbl, \$5.00; per bukb. 200 Landreths' State of Maine. . . . . . . per bbl. $\$ 5.00$; per bush. 200 Mammoth Pearı . . . . . . . . . per bbl. \$ \$.50; per bush. 175 Peorless . . . . . . . . . . . . per bbl. \$4 50 ; per bush. 175 
Prince Idward Islaud Rose. . . . . . per bbl. \$4.50; per bush. \$1 75 Green IIountain (especially recommended) . per bbl. $\$ 5.00$; per bush. 200 suownake. . . . . . . . . . . p per bbl. $\$ 4.50$; per bush. 175 Peach Blow, Jr. (see mge 33$) \ldots \ldots \ldots$. . . . . (SoLd out) Golden Harrest (see page 33). . . . per lb. postpaid, 25c.; per $1 / 4$ bush. 150 Sweet Potatoes-Tellow. . . . . . . . . per bbl. ş.00; per bush. 125 Potato Seed-Hy-zridized

\section{POULTRY FOOD AND REQUISITES.}

Pratt's Poultry Food. . . . . . . . . . . . per pkg. 25 Pratt's Food for Ilorses and Cattle.-In 12 pound sacks . . . . . . 5 Anerican Developing Food . . . . . . . . . . . per plig. 25 Clieltenlam Ponltry Food . . . . . . . . . . . . . . . . pkg. 30 Coarse Ground Bone . . . . . . . . . per $100 \mathrm{lbs} . \$ 2.50$; per $1 b .05$ Chicken Founts, Stoneware . . . . .2 gal. \$1.20; 1 gal. 90c.; 1/2 gal. 70 Chicisen Founts, Gaivanized. . . . . . . . . . . . 50

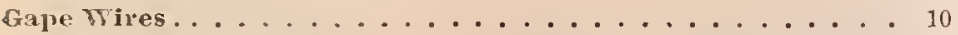
Gromnd Oyster Slrells . . . . . . . . . $200 \mathrm{lbs} . \$ 1.000 ; 5$-1b. pkg. 10 Haven's Clinax Coudition Powder . . . . . . . per pleg.

\section{RAPE SEED.}

Englinir (imported) . . . . . . . . . per bush. $\$ 5.00$; per pint, 10 German Summer (imported) ........ . per bush. $\$ 1.50$; per pint, 10 RICE.

Inlunllen. . . . . . . . . . per bush. $\$ 3.00$; per pint, Wild Rice. - Grows well on the borders of the Northern lakes, and aftords a valuable food for wild fowl. It germinates readily, and atapts itsclf to fresh-water situations in the climate of the ilidale states, and has been found very valuable sown on the water-flats of shonting-grounds, and is becoming in large denand. . . . . per lb. 30

\section{ROOTS (In Season).}

Articholie, Jerusalen Tubers . . . . . . . . . per bush. 250 Asparagus-Conover's Colossal . . . . . . per 100, 75c.; per 1000500 Asparagus-Palmetto........... per 100, 90c.; per 1000550 Hop Roots . . . . . . . . . . . per 100, $\$ 2.00 ;$ per doz. 50 Horse Radish Sets. . . . . . . . per doz. 15c.; per 100. 50c.; per 1000400 Rhubarb Roots

\section{RYE.}

White.-Pure strain of White Winter Rye . . . . . . per bush. 100 Thonsand-fold . . . . . . . . . . . . per bush. 140 Spring.

SEED DRILLS.

J. T. Case-Keeler seeder (see description and illustrations on pages

46 and $47 \ldots \ldots \ldots \ldots \ldots$ each, 900

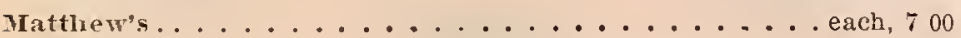
ver Moded . . . . . . . . . . . . . . . each, 600 SEED SOWERS.

Cahoon Broadeast.-Iand. . . . . . . . . . each, 400 Calnoon Hroadcast.-Horse.............. each, 1200

\section{SOAPS.}

(SEE ALSO INSECTICIDES.)

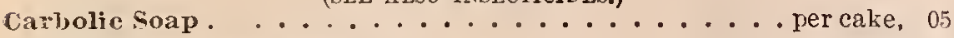
Carbolic A cid and Wliale oil Soap . . . . . . . . . per cake, 06 Hellelore, Tobacco, Whale Oil, etc. . . . . . . mixed, per can, 15 Whaie Oil \$oap. . . . . . . . . 2-1b. can, 15c.; 5-1b. can, 40c.; per lb. 05

\section{SORGEUM.}

Common or Chinese. ...................... per lb. 06

Early $\mathrm{nmber}$-This variety of cane is of extra early maturity, and is, therefore, infinitely superior to all other varieties which ripen so late as to afford but little time for pressing between the periods of maturity and frost. Very remarkable results are recorded of its sugar-producins qualities ......................... per lb. 06

Early Orange.-Fuller than the Amber, thicker in stem, more foliage. Said to be a valuable variety. . . . . . . . . per lb.

\section{SUNFLOWER.}

Russian.................. per bush. $\$ 1.75$; per $1 b .08$

\section{TOBACCO.}

Like all other cultirated plants Tobacco bas its rarious forms, gruali. Like all other cultivated plants Tressive Tobacon grower flants on! ties and assortments, and bibe pospects soil and his mariset. broth of those most profitable to bim, as respects soils. with rich op $\approx$ sils gen which must be studied. Red clay subsol Tobacco. Soils compason of erally produce tbe best dark rich export robarco. clas, develop the sand or gravel, with subsoil of light brown or rend of allivial soil best stemming Tobaccos and fillers. Flat lotrlands of alt tbe only give the best cigar types. Limestone soils, dark and ricb. are to only soils adapted to White Burleigb, which, wben well grown, is very choice. Slaty soils produce the best quality of tbe rellow wraf,ping sorts. The list of so-called varieties of Tobacco runs up into bundreds mants. The result only of a difference in soil. Tre bare selement a lim many the result only of a fisuch as will meet any requirement under ited number of varieties of such as we solicit onders for seed, reelieving the classification of adaptability knowinga cbange of seed. whien eront ourstocks to be of excellence, and knowinga can be obtained, is generally of great ad vantage to the l lanter.

The varieties of seed which we offer are as follows

MOBACCO-Yellow Plug Wracpers (LOSG-LEALED GROTTH.

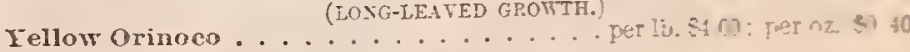
TOBACCO-Dark Plag Wrappers. (BROLD-LEAVED GROWTH.)

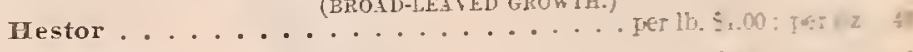

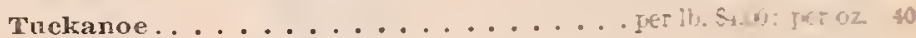

TOBACCO-Slug Fillers.

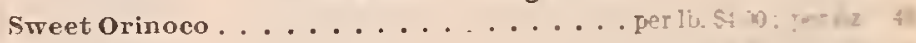
Flanagan...................

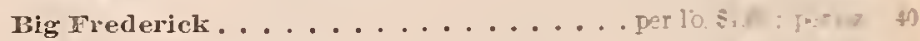

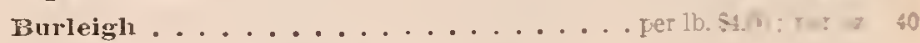

TOBACCO-Cigar Fillers

Landreth. -Early, large, thin, silky, enormonely prodt ing highest price among the Tobacco dealers of Penna rat. .

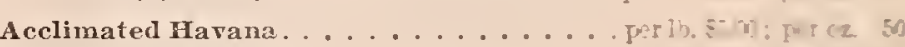
Connecticut Seed Leaf. . . . . . . . . . per lis st ni f poz. \&

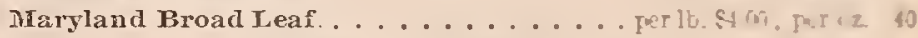

\section{TOBACCO-Cigar Wrappers.}

Landreth. - Early, large, thin, silkr, enormously podnctire an i bring ing higbest price among tbe Tobacco dealen of Pennaylvan a

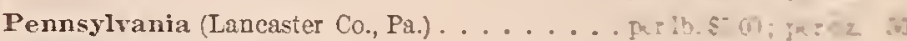

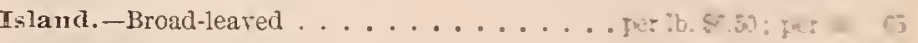

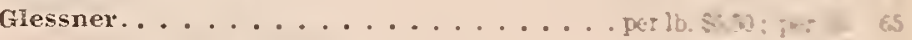

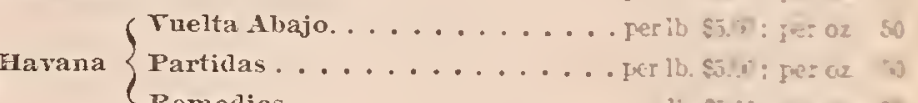

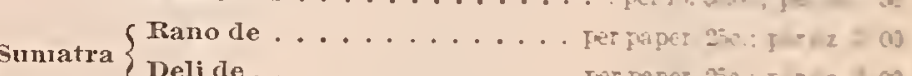
TOBACCO-Cigarettes.

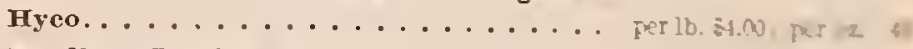

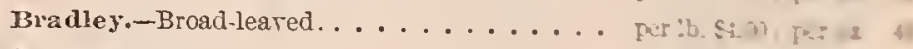

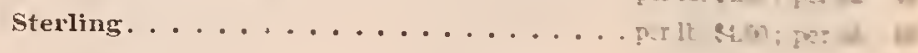
Turkish \{

Blue Pryor

TOBACCO-Snnf́.

Flanagan

VETCEES

Spring

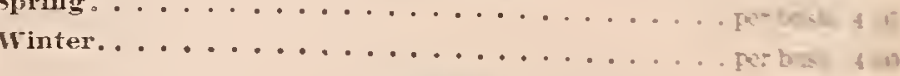

WEEAT.

Dietz Longberry . . . . . . . . . . . . . . . . . . . . . . . . . . . .

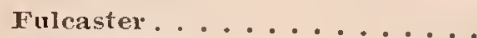

p.: basen in

LANDRETH

Re: these. is 3

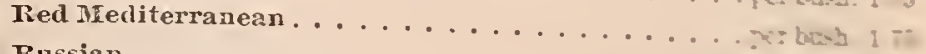

Russian

Scotch Fife,-For sowing in Spring (see thiri nage of coret. $\mathrm{N}$ - wash 17 


\title{
THE LANDRETH LAWN GRASS MIXTURE
}

\author{
FOR PARKS, CROQUET AND TENNIS GROUNDS, CRICKET RED ATULETIC FIELDS.
}

The Landretli Lawn Grass Mixture which we offer should not be compared with the cheaper prcparatious advertised. Our prescription is of the best chosen virieties and clear of weed seeds. Any one who purchases cheap, ill-chosen Lawn Grass will soon realize that it was a poor investment, as the error stands oit in glariug ugliness.

\section{SEEDING $\mathbb{L}$ IWN}

Much of the success of Lawn making depends upon the preparation of the ground. The land must be well plowed or dug and harrowed or raked to secure thorough pulverization, and after beiug reduced to a perfectly even surface sinould he cleared ot stumps, stones, roots and other inpediments. The soil chould then be made firm with a heavy roller and top-dressed witb a good tertilizer, unless the land had received an application of scren to eight tons of very short well-rotted stable mauure before plowing. We will here remark that stable manure is the best of all fertilizers, but there heing some difficulty in obtaining it and objections to its use on account of its offensive appearance and smell, we recommend a gond grade of conceutrated conmercial fertilizer (see 1age 42). Six to seven hundred pouts to the acre of such mixture should be applied. The fertilizer should be lightly harrowed in upon the seedbed, as it will be lost to the youug plants if buried much beneath the surface. After the harrowing the ground should be severely rolled, that the earth and seed may be brought into close contact. Our Lawn Grass Nixture should be sown at the rate of forty poinds to the acre and rolled down. Sowing in September and October will be found most advantageous iu latitudes south of Philadelphia; in more uortherly locatious Spring sowing is most successfully practiced, the work being done in April and Nay.

Annual seeds, natural to the soil, are certain to spring up before the young grass becomes established, and an inexperienced person is likely to conclude that the weeds spring from weed seed iu the grass sced, but all soils contain weed sceds, and upon tillage they are certaiu to vegetate. The weeils as they become large enough may be cut down or pulled up; after tbe first year their growth will cease. Frequeut rolling is adrantageous in producing a good Lawn by solidifying the soil, harassing insects and other rermiu, and improving the level of the surface. Lawn by solidifying the soil, harassing insects and other rermiu, and improving the level of the surface. interesting study.

Ou all Lawns will regularly appear in greater or less numbers a lot of interlopers, such as Buttercups, Plantains, Dandelions, all from seeds natural to the soil. These uninvited guests should al ways be dug out, otherwise subsequeut labor will be increased one hundred fold by their seeding. Larns may be advantageously dressed with stable mauure in Decembcr, the loug strawy portions being removed in Mfarch

On those portions of Lawns as around the house, where an immediute result in grass effect is desired, sod may be used. Fair sod can generally be had on roadsides, aud if carefully taken up and when laid down accurately jointed and solidified and corered with half an inch of rich compost it will at ouce start off and very soon be as mucli a fixture as the adjoining trees and shrubs.

Law u Grass of good quality should produce a fair mat of herbage in from seveuty to ninety dars.

Some parties offeriug Lawn Grass at a low price are using the so-called Canada Blue Grass, which is not ouly worthless but a pest alld difficult to eradicate.

Some people, after seeding a piece of land with Lawn Grass, expect to see a green mat in two or three weeks, but in this they are unreasonablc, as the hetter varieties of grass are slow to produce effect, and when an effect is quickly developed it is at the expense of adaptability and permanency. For instance, a five mat of green color can be had in two weeks from a heary sowing of Thite Clover, something very effective and pleasing to the eye, but clover is not a grass aud is not suitable for Lawns, failing to produce that velvet-like effect, the result of the growth of the erect leavcs produced by the best grasses, which habit fits them to quickly recover after mowing.

Manures or fertilizers for Lawns may be of many combinations. We recommend to those who prefer to do their own mixing a compound of

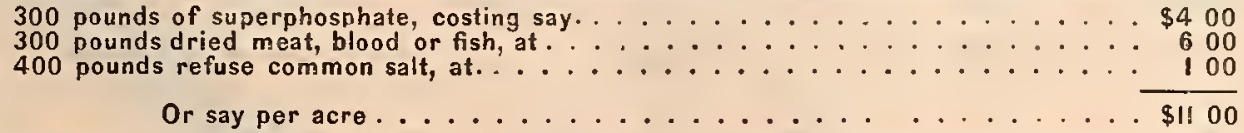

The quantity of superphosphate and nitrogenous matter may be doubled to advantage, or eveu made stronger, as grass will stand almost any amount of fertilizer.

The common salt used as an alterative aud solvent will be found to have a decided influence in kecping up the emerald green condition so desirable on a perfect Lawn.

Not more than threc busheis to the acre should be applied in a season, and then best during a rain-never uuder a hot sun.

\section{GRISS FOR SURF ACE EFEECT.}

This prescription consists of 100 parts, divided in such proportion between those grasses which our observation has indicated as best for general Park effect, as respects color, dellsity of herbage, vigor, quick recuperation after mowing and permanency. The sceds used are all well cleaned and we believe them to be pure and of full vitality, and all persons using them are certain to secure a stand, provided the land be properly prepared and the seed sown at the proper time and at the right depth, and provided there bc sufficient rainfall to germinate the seed. We camnot be responsible for the errors of the inexperienced. A pouud of seed will sow a space $40 \times 20$ feet, or say 800 square feet. Forty pounds will sow an acre, hut we recommend sixty pounds. Price per pound, 25 cents.

\section{GRASS TO RESIST TRAMPING ON A THLETIC GROUNDS.}

This prescription is also of 100 parts, but differs from our Park Lawn Grass in the list of rarieties, a proportion of such sorts being here added as to better stand the wear and tear of tramping consequent upon games of Tennis, Cricket, Lacrosse and Base Ball.

A pound will sow a space $40 \times 20$ feet, or say 800 square feet. Price per pound, 2 ; cents.

old Lawns much in decay had best be ploughed up, leveled up and resown, hut often this course is not convenient, certainl not if the Lawn can be renovated by a system taking less time. In that case, when prompt results are desirable, the old sod should be well combed by a harrow to tear out the dried grass and easily extracted dead roots. This operation also hreaks the earth, putting it in a pul verized conditiou to receive seed, which may be sown broadcast, and falling between the living grass, roots into the friable and fresh soil, and is at once in position to germ inate and occupr the space. On miny Lawns cut with the lawn mover there appear many into the friable and fresh soil, and is at once in position to germinate and occupy the space. with the lawn mower the re appear many pests - the Creping Veronica and the Monse-Eared Chickwecd bcing prominent-which crovid out desirable grasses will admit of such close cutting as to destroy all pestiferous plants. The seed of sheep Fescue costs about 15 cents per pound.

\section{Pásturage Grasses.}

The judicious selection of grass seed for the creation of a durable pasture requires a knowledge obtaincd only by an intimate study of the habits of varieties as respects quality of herbage and rigor of constitution. Except in the Blue Grass sections of jentucky and Tennessee, it is not suthicient always to select the one grass indigenous to the district, for it may not possess the double quality desirable for green pasturage and hay, for hardiness and permanence, which combination of qualities and character is best found in a mixture of sorts. That prescription, to be thoroughly scientific, should be adapted to the conditions vary so much that no be it slaty, calcareous or alkaline, as well as the mechinical condion of the soll, be it sandy, loamy or claye. prescribe for soils heavy, as clay or deep loam; medium, as light loam or peat; light, as sand, slate or gravel. Pasturage Nixture for Meavy 5 ils. - Forty pounds to the
acre. This prescription consists of 100 parts of such grasses as experience has indicated as productive in herbage and most durable on heary soils. Per lb. 25c.; per 100 lbs. $\$ 23.00$.

Pasturage Mixture for I,ight Goils.-Forty pounds to the acre. This prescription of 100 pounds, divided into practical proportions between such varieties of grasses as proved by experience to be the best manence. Per lb. 25e.; per $100 \mathrm{lbs} . \$ 23.00$.

MARION, ALA.-Your seeds are cxcellent. My father used them and so did my grandfather, over fifty years ago, when they lived in Virginia. 


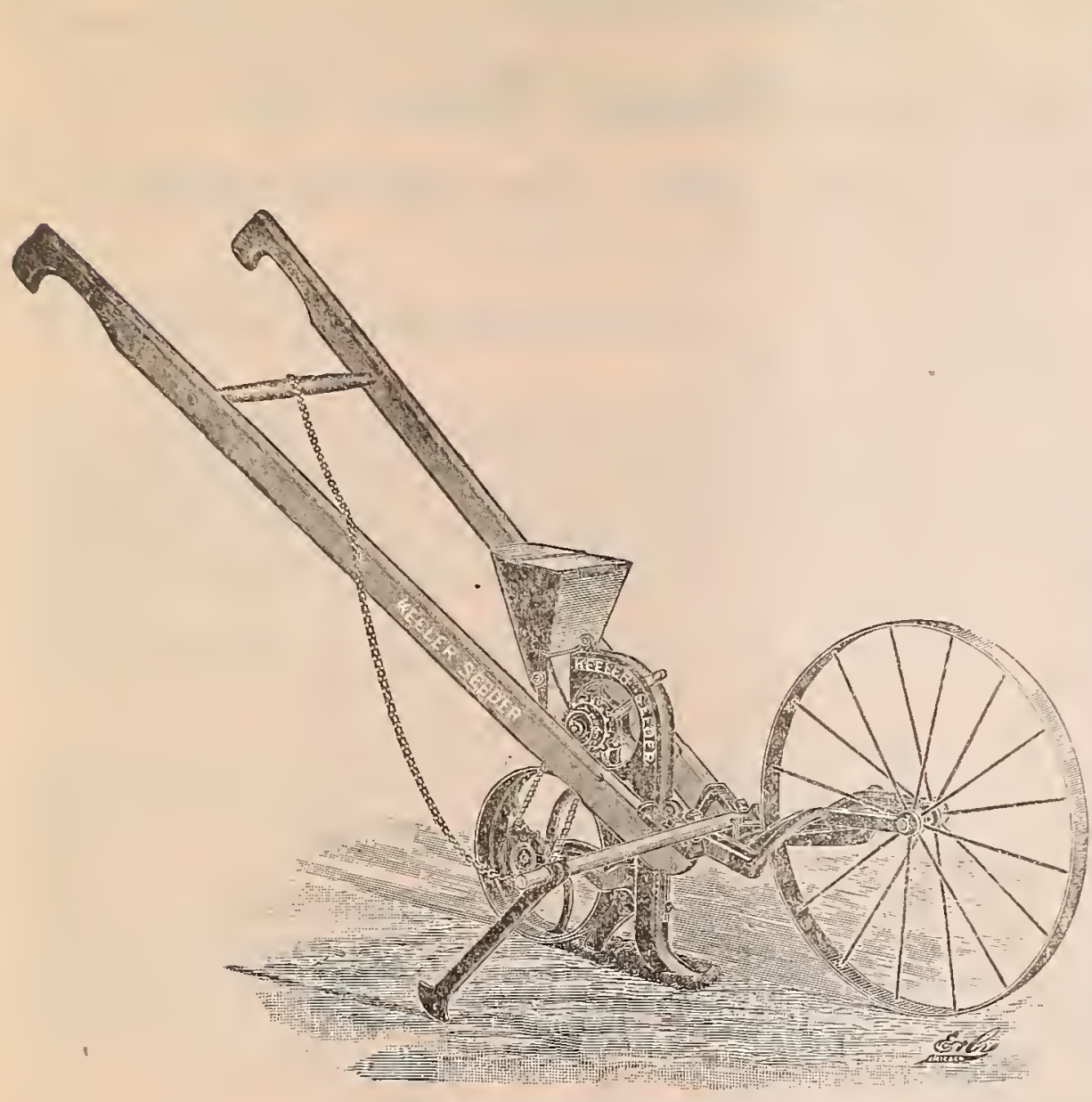

J. I. Case-Keeler Seeder, Complete.

Price \$9.00.

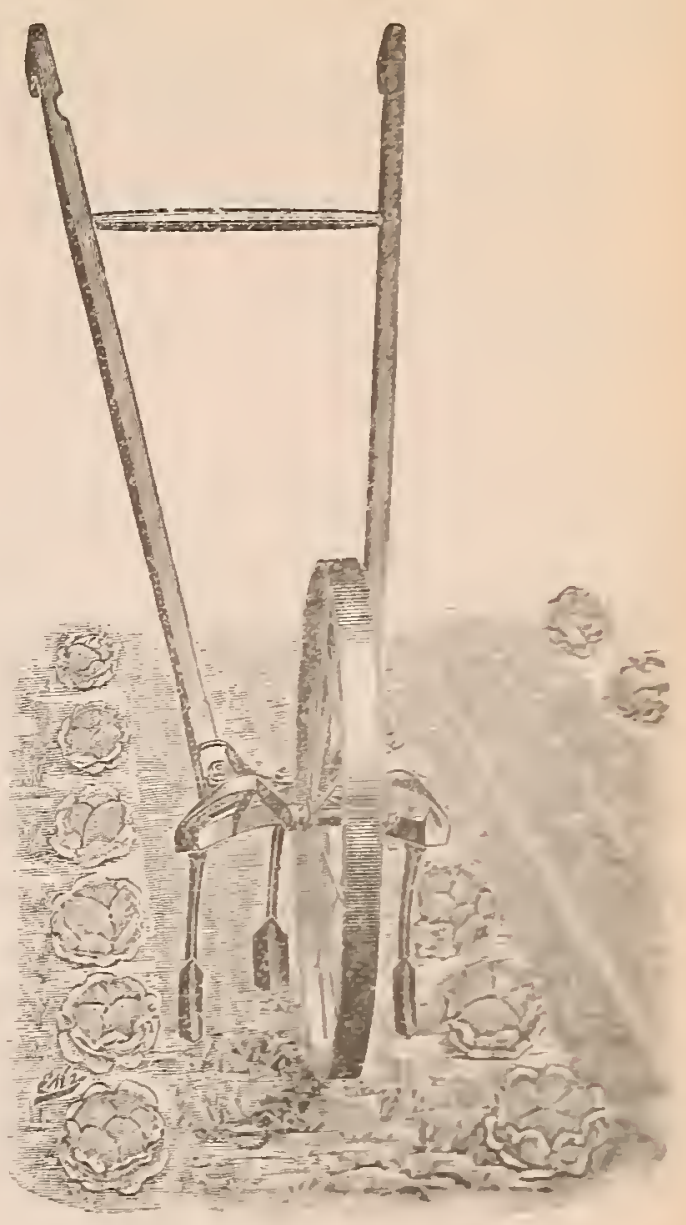

J. I. Case-Keeler Seeder Frame. (RIGGED is a CCLTIVATOR.)

\section{The J. I. CAse-KEeler Seed Drill.}

$\mathrm{W}$

Q have arranged to handle the $J$. I. Case-Keeler Seed Drill and Cultivator - a hand implement quickly altered from a Drill to a Wheel Hoe. The seeding device is the most reliable we have ever seen and presents combinations never before practieally developed in any other machine. Under these simple combinations the Drill rill sow in a continuous row, or drop the seeds in hills at intervals of $6,12,18$ or 36 inches. It is as equally reliable when sowing Salsify Seed, the most difficult of all seeds to distrihute, as when sowing Turnip Seed, the easiest.
Tine seech, as Cucumbers and Melons, can in sown in HILLS with perfect recularity. anl cis. planted in continuous rors or at such iniersal - . may be desired.

When to be used as a Cultirator the drill! it $1 .$. made of iron and brass and rust proof, can l $\mathrm{w}^{3}$ julchly detached, and the plow, loe or rake as quachly : tached.

Te hare used this Drill on Blooms inle F. rm :...

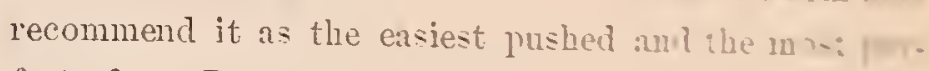
feet of any Drill in the market.

\section{COMPLETE DESCBIPTIVE AND ILLUSTRATED CATALOGUE MAILED ON AFRIILAION.}




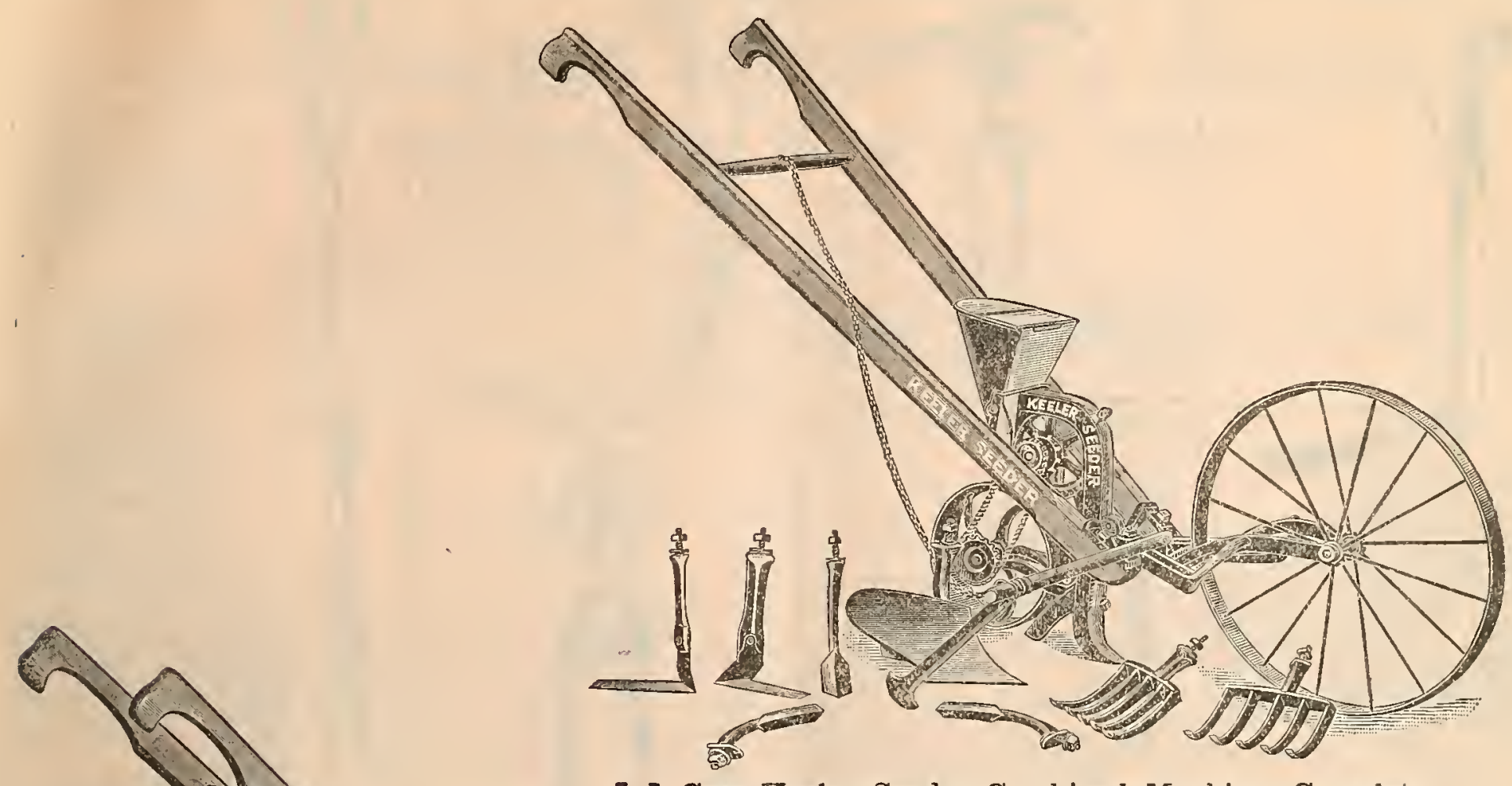

J. I. Case-Keeler Seeder Combined Machine, Complete. Price $\$ 12.00$.

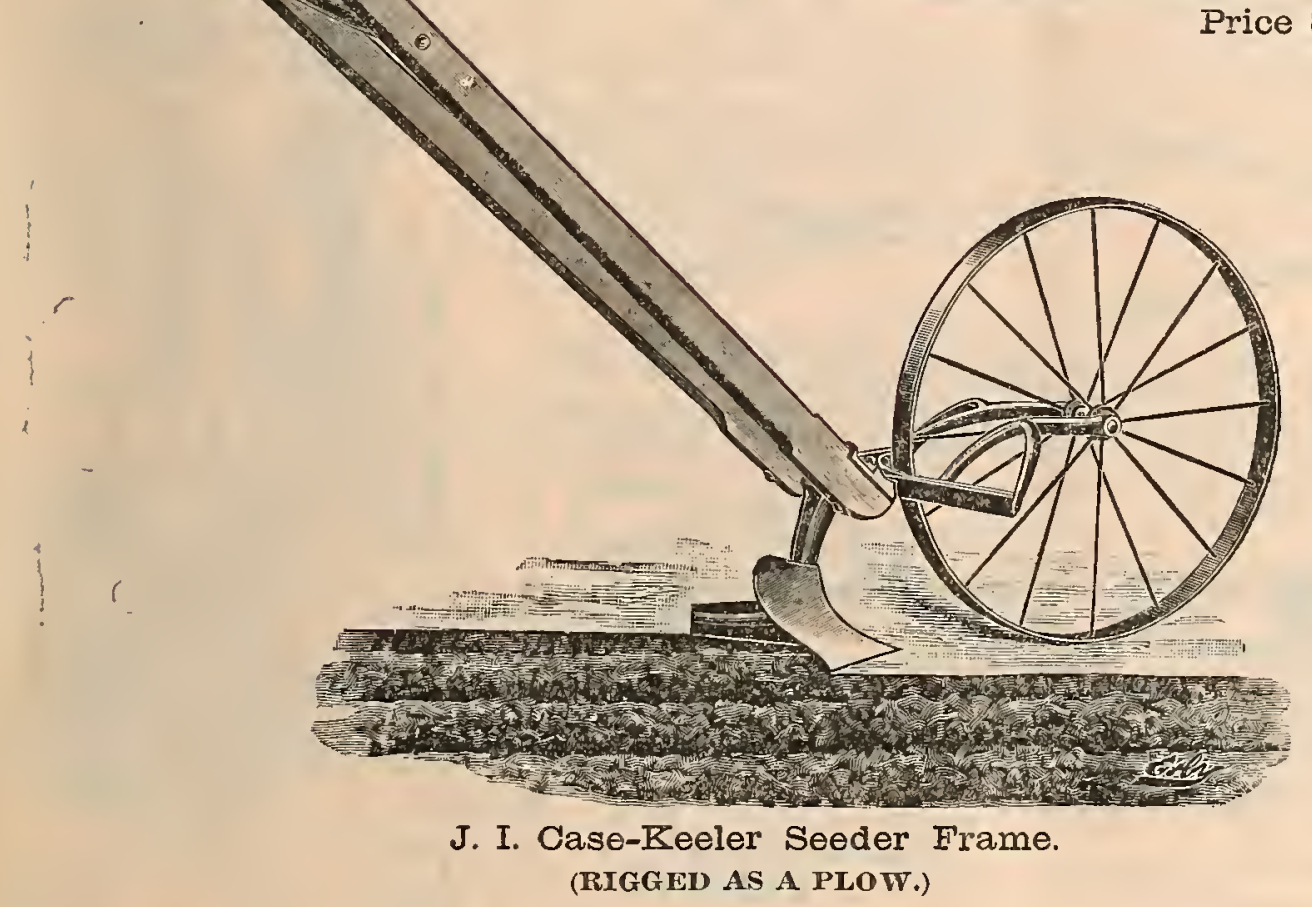

\section{GRASSES FOR POOR, SANDY SOILS.}

On page 45 we offer Mixtures of Grass Seeds for Lawns, Athletic Grounds and Pastures for Heavy and Light Soils--mixtures made after private prescriptions, containing certain percentages of such seeds as our observation has proven suitable for the object in view.

We here offer another Mixture for Poor, Sandy Soils, and believe it will be found valuable where 'Timothy, Red Clover, Orchard Grass and other well-known sorts are not to be depended upon. Per lb. 25c.

We will, however, be pleased to name a price for any mixtmre which our customers may indicate and will guarantee a perfect compliance with their provisions. 


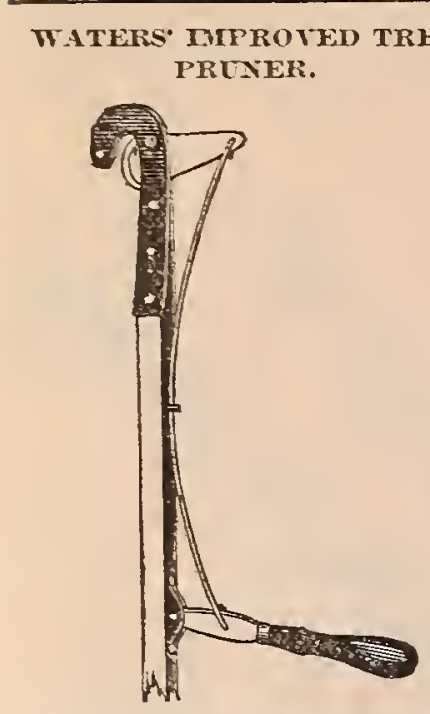

The thin blade of this pruner passes through the limb so easily that the throun is uninjsired and the bark left grain ts uning is ated on both sides by the steel hook, which guides and by the steel hook, which guides and prevents it from turning from the straight line of the cut. or donbling orer small twigs. The lever at the lorrer end is connected by a steel rod with the blade, in such a way as to give great power. On poles 4 to 12 feet long.

\section{BRA YCH OR LOPPIYG SHE IRS} AND HEDGE TPIMNER. IcIlhenny Pattern.

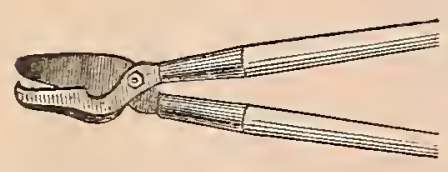

These shears are stronglr made. and the peculiar shape of the blades adapts them equally to cutting large branches or small twigs. Handles 30 juches long.

\section{DOCK EXTRACTOR.}

A rery effectual instrument for raising dock roots. A piece of wood through the ring underneath forms a fulcrum and enables the operator to raise the root easily. Nade with or with. root easily. Nade out wood handles.

\section{TFEDING SPUDS.}

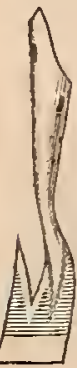

Are of different styles, some with straight blade only, and others with a curved or sharp hook on the side. The farmer walking over his fields with one of these little instruments one of these his cane, is ready to eradicate any voxious weed he may observe.
LITTLE GEII WEEDER.

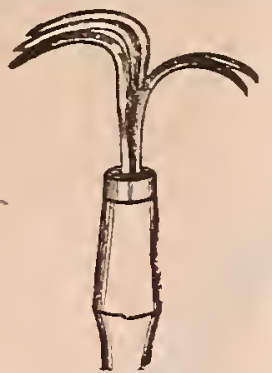

Has three fingers on one side and a claw-finger on the other. Very handy for use in Strawberry beds and Flower borders.

\section{EXCELSIOR WEEDING HOOK.}

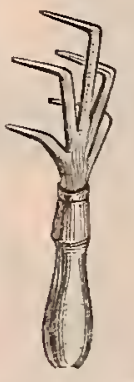

A handr little implement to loosen the earth and pnl out weeds.

\section{BRAXCH OR IOPPING} SHEARS.

Englisli Pattern.

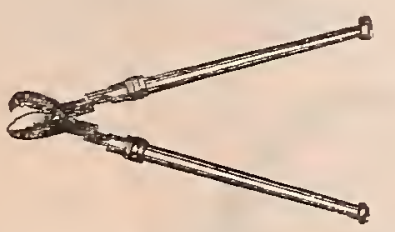

Foursizes. Made rery strong. Handles from 24 to 30 inches long. For cutting heary branches in hedge plants or shrubbery.

\section{GRASS SHEARS}

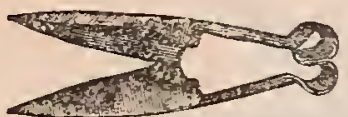

In shape like sheep shears. with -1/2-inch blades. Tery convenient for trimming and eutting grass on smail trimming and cutting grass on smat places. Made with or without spring.
we have also the ordinary sheep shears of the best quality.

\section{HAND PRTNING SHEARS.}

Telescope Springs.

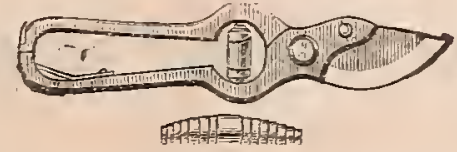

These are hand-forced solid steel Cut with ea-e. Sereral sizes are made. One is uickel-plated, weighs only three ounces, and small enough to carry in the vest pocket. Very convenient for ladies' 1 .

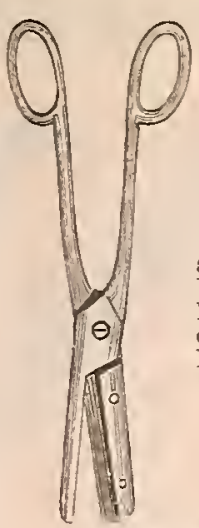

FLOTER SCISSORS OR PICKERS.

These are Scissors and Shear combined. and shear combing and Used for cutting and other flowers that have thorny stems. Several sizes.

HAND PRUNING SHEARS. Frencli Pattern.

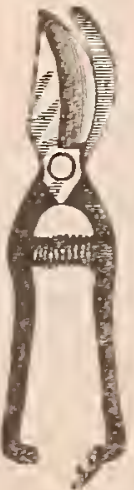

Hears-frame shears, with strong spiral springs.

LADIES PRONITG SHEARS.

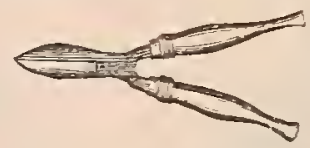

Neatly-furished handles with brass errules; blade six inches long. L'sed for ligbt trim ming.

BOW PRENING SCISSORS.

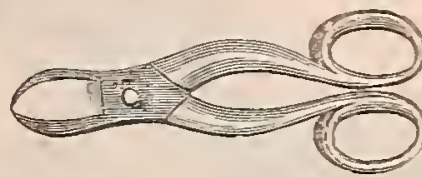

So named from the shane of th bandles. Very useful for trimming hrubbery, roses, etc. Hare nospring: Several sizes.

\section{GARDEN TROWELS.}
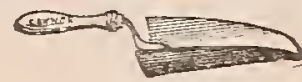

T'sed to take up, for replanting, herbaceous plants, small shrubs, roots. etc. Alsoused for stirring soil amongs tender plants, remoring weeds, etc. We have the solid welded blades of s inches long.

TRANSPLANTIT TROWEL.

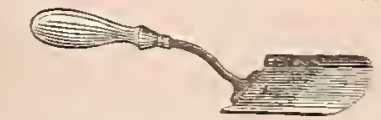

Have broad flat blades, used for transplanting ouly.

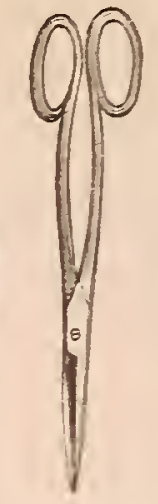

TIE $\rightarrow$ Is OOP:

The long points. blarle are very eis in thimping out Grut ahen ton cluse cei

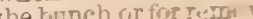

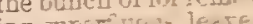
ing $=$ w IWigs, EtC

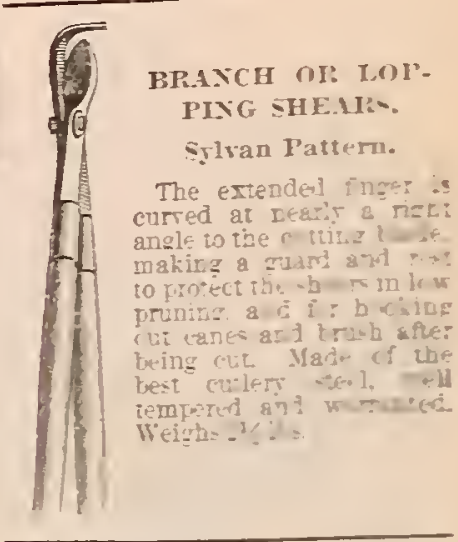

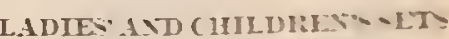
OF FLOR.IL TUUL.
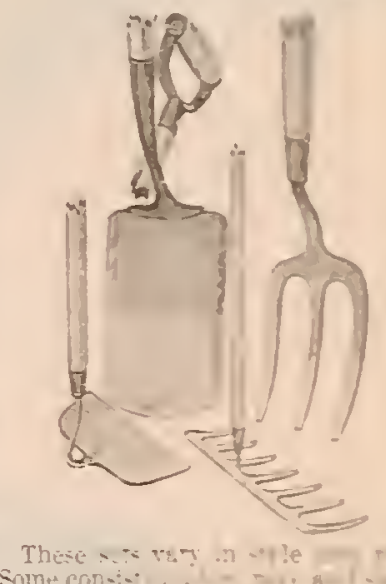

ounte can-:-: adimongl.

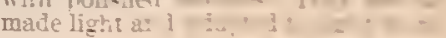

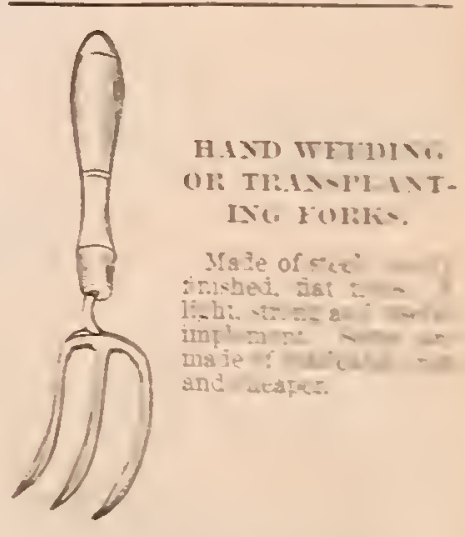




\section{LANDRETHS' UEGETABE SEEDS}

\section{In 5c. or 1oc. Flat Papers and Packets.}

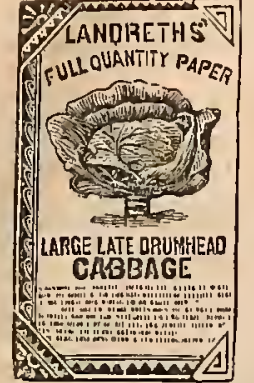

A Flat Paper or Packet. All Vegetable Seeds are put up in this form. $5 \mathrm{c}$. and $10 \mathrm{c}$.

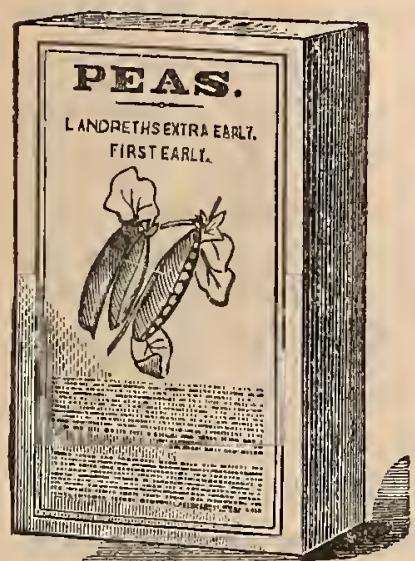

A Pint Package.

Pens, Beans and Corm are put up in this form and in Third Pints.

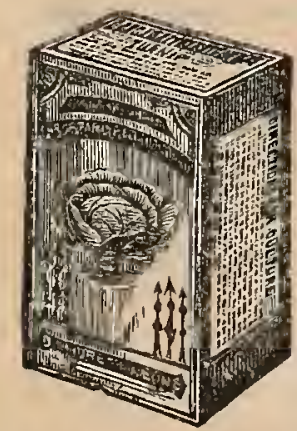

All smaller Vegetable Seeds are put up $i 11$ 1/4 and $1 / 2$ pounds and will be supplied at the rates per pound naned in our priccd list, pages 4 to 37. P'ostage, if by mail, 8 cents per pound additional ( $1 / 4$ pounds and under mailed free of postage).

\section{Landreths' Specialties in Bulk (Under Seal).} sold by us or by merchants, appear only in bags, wired and sealed with our "Bell" Trade-mark, to distinguish them from imported imitation and spurious stock; offered at lower prices :

Landreths' Extra Early Peas, in red bags, of $1,1 / 2,1 / 4$ and $1 / 9$ bushels.

Landreths' First in Market Beans, in bags,

Landreths' Srarlet Beans, " "bags,

Landreths" Violet Beans, " "bags,

Landreths' Pink Eye Wax Beans " bags,

Bloomsdale Spinach, in bags, of $5,10,20,30$ and 40 pounds.

small seeds put up

Quarter Pounds.

We du not sell Seeds on Commis. sion, nor do we sell Cheap Seeds.

To be able to buy seeds at low prices, is to inexperienced persons a tempting consideration but those who are critical know that one-hali the quantity of good seed will produce a better good seed will produce a better
stand of plants than double the stand of plants than double the quantity of inferior seed, to say rothing of the quality of the test in the garden the fllusion us to chenpness is rudely and expensively dissipated.
The following varieties (Specialties exclusively our own), whether

No charge for bags and sealing. See prices, second page of cover.

\section{Landreths' Vegetable Seeds in Bulk.}

All the other varieties of Vegetables, as well as Field and Agricultural Seeds, named in our list, whether by the pound, bushel, ounce or quart (or precisely the quantity you nay need), we will supply at the prices named on pages 4 to 44 . See our" Remarks to Purchaser's," second page of cover, and mail your orders early.

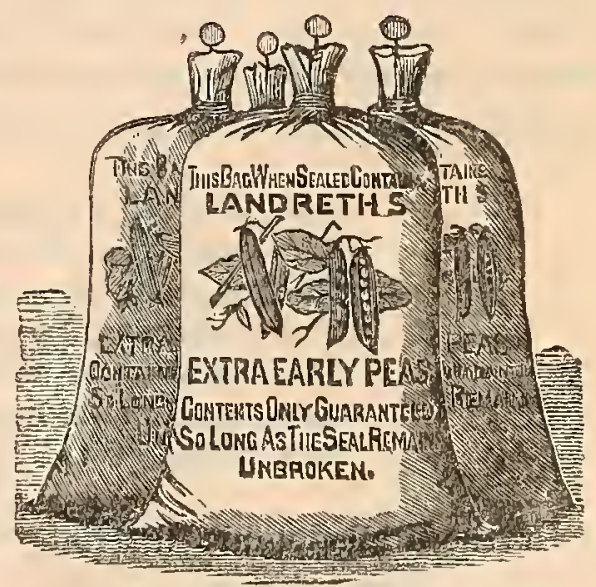

Pedigree Stock. Introduced by ves in 1823.

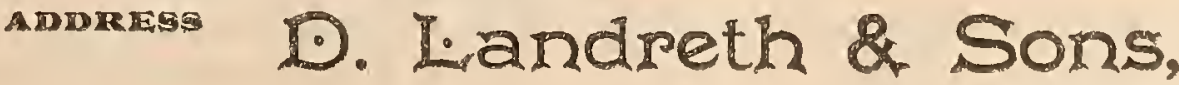

PHILADELPHIA, PA. 


\section{MARIKET GARDENING FOR NORTHERN SHIPMENT.}

The unprecedented development in Florida and Georgia and other far Southern States of the business of growing vegetables for A utumn and Winter shipment to the cities of the North, to be from those active business centres more widely distributed among the densely populated districts of the Middle, Western and New England States, has been one of the surprises in Agriculture.

Formerly esculent vegetables could be divided into classes, and a period named covering the time of sale of each class-as, for example, Peas were only offered during May, June and July-and so with Cucumbers, Tomatoes, Egg Plants and Beans-they all had their seasons, and when they were past, only those people who had greenhouses could expect more until the return of the corresponding season the following year, but now that is a condition of the past, for Florida with its evergreen productiveness has been able to revolutio_ize the old conditions, by sending to our Northern cities, even when snow clad and ice bound, the fruits of balmy Summer.

From such a perennial field there are now offered, at all times, vegetables which at first surprised the observers and were only used by epicures, but which now have become a necessity, not only on the table of the rich and well-to-do, but of every hotel and restaurant.

Thus, thanks to Florida, the general public of the whole country have luxuries at their command, which their ancestors never even hoped to obtain, and the now familiar products of Florida have brought that State more prominently to the notice of the Northern people than has the wheat and corn of any Western State made its name known, for grain products do not carry with them their own identification as do Cucumbers in March, Egg Plants in December and January, Tomatoes in January, February and March, Cauliflower in . Narch and April.

The value of the output of $T$ inter regetables from Florida, and the value of the quantity consumed by the Winter guests of its hundreds of hotels, tips the scale at a valuation of several millions of dollars. a large sum considering that the cultiration is yet in its infancyfor the production of regetables in Florida is certain to develop to an immense degree, as no competition can come from a more Southern district. The profits of the Norfolk truckers mere cut by the Charleston and Saran. nah market gardeners, and they in turn by the Florida cultivators, but the Gulf is south of Florida. so competition stops, or becomes merely inter-State, there hing no neighbors southwardly to compete witi earlier firoductions.

Market gardening during the past ten rears has grown to such an enormous extent that extracts from ibe $1 a-i$ Census Reports only can conrey an idea of its unimculous development.

The Report shors that $\$ 100.000 .000$ is invested in Truck Farms corering 534 thousand acres, and prolucing an annual return of $\$ 7,000,000$ after paring all freights and commissions.

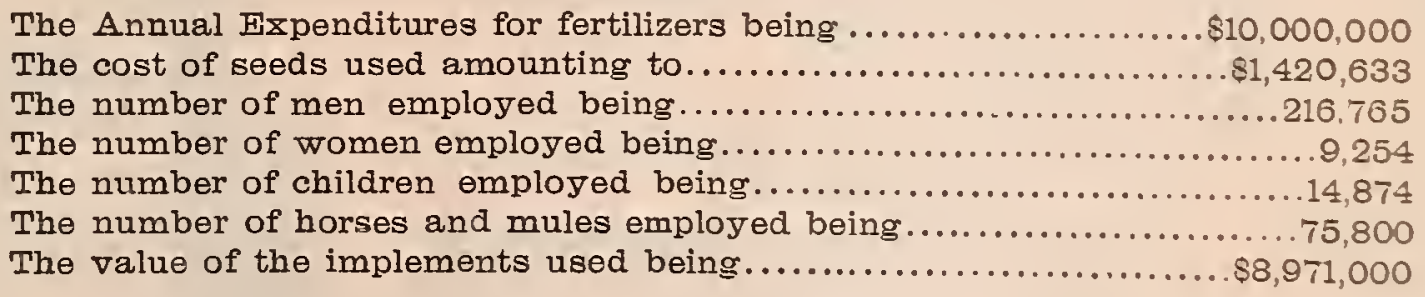

In the Philadelphia district, which includes Pennsylvania, New Jersey and New York, there are employed 69,000 men at an average cost for daily wages of \$1.1\%. The annual production being of the value of $\$ 21,000,000$.
The next district of importance is knomn as the Ceatral, extending orer the State of Obio and up to Misconsin, wherein is employed 34.000 men, at sil areraze Wages cost of $\$ 1.16$ per dar, and producing an annual valuation of $\$ 15,500,000$. 
The South Atlantic district is the third in importance, having an output of $\$ 13,000,000$ and employing 31,000 men, women and children at an average daily wages of 85 cents.

As an example of the market gardening output at Norfolk, Va., it may be interesting to note the extent of some of the shipments made from that city in 1889 .

\begin{tabular}{|c|c|c|c|c|c|c|c|}
\hline Cabbage, & - & - & & - & - & 347,000 & barre \\
\hline Kale, & - & & - & - & - & 178,000 & "6 \\
\hline Onions, & & . & & . & . & 4,800 & "6 \\
\hline Radishes, & - & & - & . & - & 4,200 & \\
\hline Irish Potat & toes, & , . & & . & . & 325,000 & 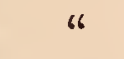 \\
\hline Sweet Pota & & & - & . & . & 255,000 & 6 \\
\hline Spinach, & . & . & & . & - & 123,000 & 6 \\
\hline Beans, . & - & & - & - & - & 80,000 & \\
\hline Cucumbers & & - & & . & - & 46,000 & 66 \\
\hline Tomatoes, & . & & - & - & - & 350,000 & 6 \\
\hline
\end{tabular}

In addition to the above there were shipped from the same city almost 1,000,000 Watermelons. And yet they say it was a poor year.
From the city of Mobile, in 1890, the shipments were :

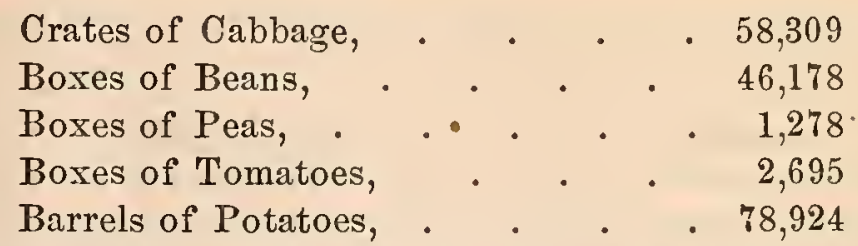

and other market garden products to a value of $\$ 458,000$.

The Philadelphia district, the Central district, and the South Atlantic district are only three of twelve districts as laid out by the Census Bureau, that of California giving an annual production of over $\$ 4,000,000$, and yet there is room for the productions of all, amounting to $\$ 100,000,000$ and no doubt in a few years that sum will be doubled, for everything doubles in this land of progress.

This wonderful increase of Vegetable gardening has been made possible because profitable, the result of two causes, cultural development and plant evolution. Plant evolution watched for and seized upon by lynxeyed men ever on the alert for new types of vegetables and fruits, and cultured power as seen in new systems of seed sowing, new methods of working by new machinery.

\section{AGRICULTURAL VALUES OF THE UNITED STATES.}

Few people appreciate the magnitude of the agricultural values of the United States. A simple enumera. tion of a few products may be interesting as indicating the interests which the farmers represent and which unquestionably warrants them in alliance for mutual benefit.

\section{ARTICLE.}

Corn crop for 1889 ,

Wheat

Oats

Barley

Potato

Hay

Cotton

Tobacco

Wool

1889
66
6
66
66
66
6
66
66

QUANTITY.

2000 million bushels.

$\begin{array}{rlc}450 & 66 & \text { 6 } \\ 750 & 66 & \text { "6 } \\ 12 & 66 & \text { "6 } \\ 202 & \text { 66 } & \text { "ons. } \\ 46 & \text { "6 } & \text { tons. } \\ 7 & 66 & \text { bales. } \\ 566 & \text { "6 } & \text { pounds. } \\ 270 & \text { "6 } & \text { "6 }\end{array}$

ESTIMATED VALUE.

597 million dollars.

$\begin{array}{rll}342 & 66 & 66 \\ 171 & 66 & 66 \\ 8 & 66 & 6 \\ 81 & 66 & 66 \\ 408 & 66 & 66 \\ 292 & 66 & 66 \\ 45 & 66 & 66 \\ 70 & 66 & 66\end{array}$

The farm animals are estimated at:

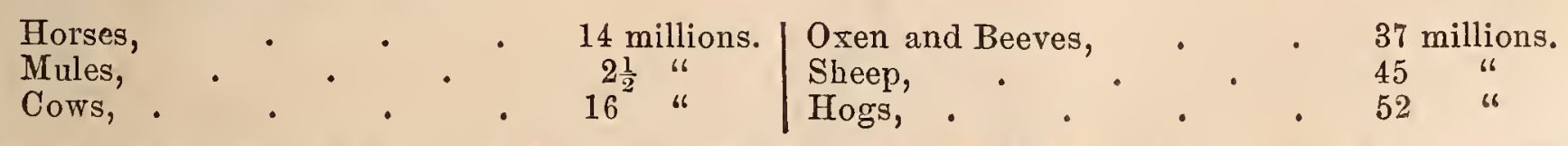

At a total valuation of farm live stock of 2420 million dollars which, with the values of a portion of the farm products, as above indicated, makes a grand total of 4454 million dollars, with an immense production of articles not here enumerated, as Sugar, Rice, Butter, Cheese, Eggs, increasing the value to over 5000 millions of dollars. 


\section{A MOTBED-W HAT IS IT?}

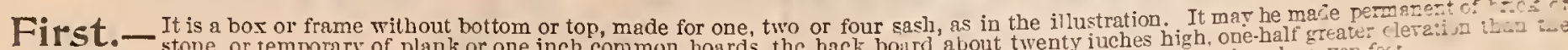
front whicl shoult or temporary of plank or one inch common hoards, the hack board about twenty iuches high, one-hali eseat feet.

The back being higher thau the irunt gives a declivity to the sash, thus custing off the raiu, which it would not do if flat.

Secondly. The bor at proper season is placed npon a hed of fermenting mateof soil resting upon it, and thus gerwinates seed and forces plants into rapid growth.

Thirdly. The value of the hed depends principally upon the character of the dung) forked opertiro or three times at intervals of a week and kept in a deep and compact pile till it besius to smoke or steam, indicating that the process of fermentation has set in. If the dung be viry rich in grain an addition of forest leave' is desirable, as they serve to prolong the period of fermentation, which otherwise might be too rapid.

Fourthly.__ Selecting a well-drained location, and one never flooded by rain, exhroader than the hox. Into this place six inches of rough barnyard manure, corn stalks, leaves or straw, for drainage, and on it lightly fork in the fermenting. duns and tramp it firmly down to a depth of two feet. Place on the hox and fit the sash lightly, cover with mats aud allow fermentation to again proceed, hankius up with hot manure on the outside all around at an angle of $45^{\circ}$. Place on top of the manure a layer of three inches of ricl, moist, finely

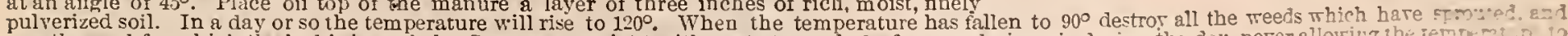

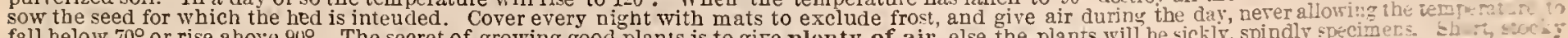
fall helow $70^{\circ}$ or rise a hore $90^{\circ}$. The secret of growing good plants is to gire plenty of air, else the plants will he siclily, spindly specimecs.

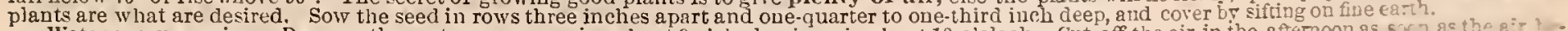

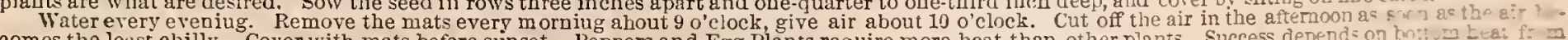
comes the least chilly. Cover with mats before sunset. Peppers and Egg Plants require more heat than other plants. Surcess depend on th:

the sedlings should he transplanted into other hotheds or intermediate beds when two inclies high.
Hotheds may he used for forcing Lettuce, Radish, Egg Plant, Pepper, Tomatoes, Cabhage, Caulifower and Ornamental Flowers.

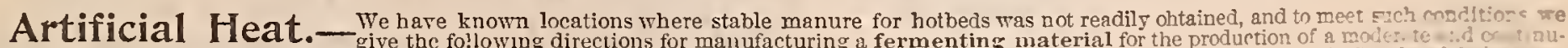

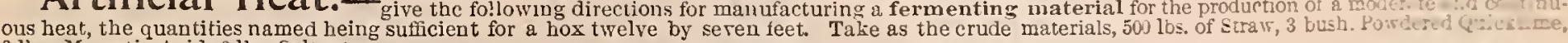
6 lbs. Murıatic Acid, 6 lhs. Saltpetre.

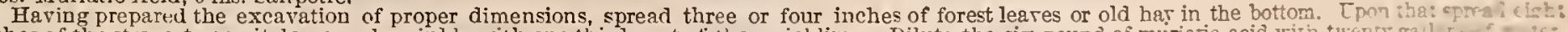

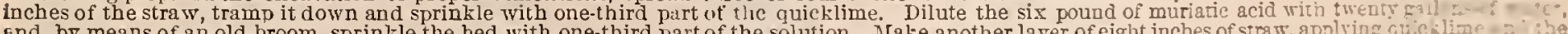

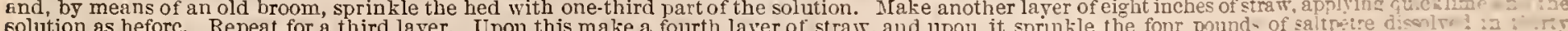

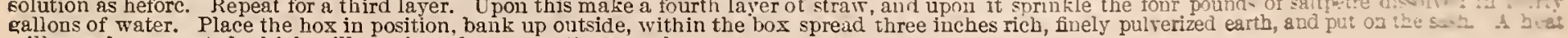
will soon be generated which will continue for two or three weeks.

\section{PARIS GREEN TO KILL BUGS.}

\section{EXPEIIIENTS AT BLOOHSDAIE TO TEST UPON VARIOUS PLANTS THEIR POWIR ON} RESIGTANCFE TO INJURY BY PARIS GREEN.

\begin{tabular}{|c|c|c|c|c|c|c|}
\hline $\begin{array}{c}\text { Paris Green } \\
\text { Parts. }\end{array}$ & $\begin{array}{c}\text { Land Plaster } \\
\text { Parts. }\end{array}$ & $\begin{array}{c}\text { Landreths' } \\
\text { Boss Waterm'n, }\end{array}$ & Acme Citron. & $\begin{array}{c}\text { Cheese Pump- } \\
\text { kin. }\end{array}$ & $\begin{array}{l}\text { Landreths' } \\
\text { Turban Squash. }\end{array}$ & $\begin{array}{l}\text { Jersey Pichle } \\
\text { Cucumbe: }\end{array}$ \\
\hline 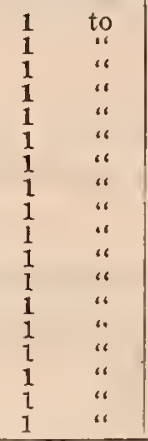 & $\begin{array}{l}320 \\
283 \\
221 \\
192 \\
160 \\
128 \\
96 \\
80 \\
64 \\
51 \\
48 \\
35 \\
32 \\
28 \\
25 \\
21 \\
13 \\
16\end{array}$ & $\begin{array}{c}\text { Strong enough. } \\
\text { " } \\
\text { " } \\
\text { Too much. } \\
\text { " } \\
\text { All destroyed. } \\
\therefore \therefore \therefore \\
\therefore \therefore \therefore \\
\therefore \therefore \therefore \\
\therefore \therefore \therefore\end{array}$ & 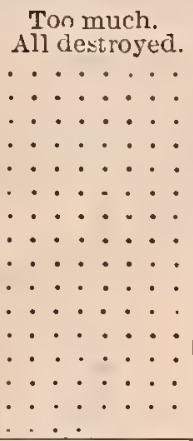 & 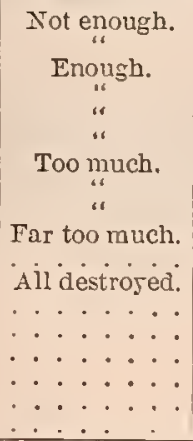 & 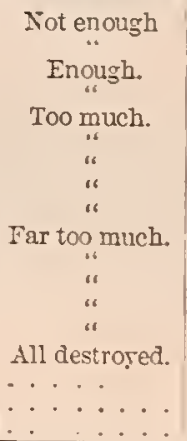 & 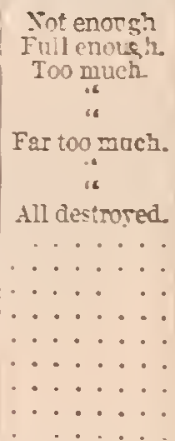 \\
\hline
\end{tabular}
Four applications made at intervals of four dars and each time the leares dusted in the early morning with Paris Greez. The Pars Grecz - . :
with ground land plaster in proportions as designated. The plants all heing in the rough leaf and two to three inches bigh. RESULT-Sqnash proved to hare the most resistance to the poison and to the stoppage of the leaf pores. Pumpkin, second so:vages: Cuenminer.
third strongest. Watermelon, fourth strongest. Citron Melon, the least rigorous.

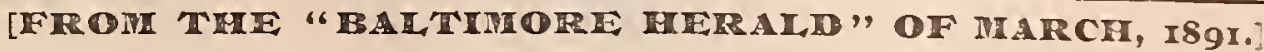

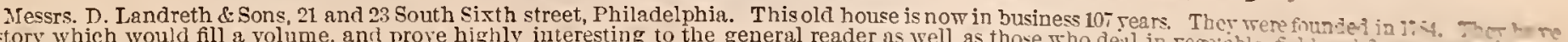

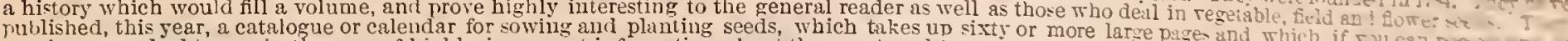
north a great deal to you in the way of highly importall information abont the way to culticate and when to sur. We and whe worth a great deal to you in the way of highly importall information abont the way to cultirate and when to sur, We have a
we know it is the experience of generations of practical wisdom. In the prestige of this old house rou have ga earness we know it is the experience of generations of practical wisdom. In the prestige of this old house you have an earnest of cop f abd ralue $1:$ noticed their farm-“"Bloomsdale Farm." The New York and Philadelphia division of the Pennsylvania Railroad runs for mea.-15t tro m.

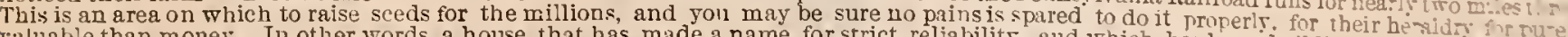
raluable than money. In other words, a house that has made a name for strict reliabilitr, aud which has beeu building for mane

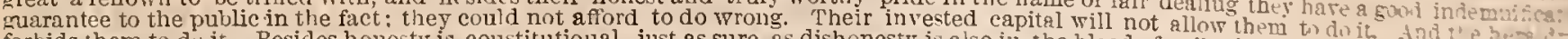
forbids them to du it. Besides homesty: is constitutional, just as sure as dishonesty is also iu the hlood of evil-minder pann? penple perish from the carth, and the "true hlue" live on. No estate gained by fraud ever descends to the third oudenenple. The only" alcs a more orise sirom the car we do of lle national renown for success in growing, aud the great no halo un less it is iu full consonance with probity and fair dealing. 


\section{SEED LIST.}

To name and describe the different sorts and so-called "variations" of Garden Vegetables, seeds of which are offered in the two hundred and one seed catalogues distributed by Seed Merchants in the United States, would quadruple the pages of this pamphlet and so confound the inexpericnced gardener that he would be unable to arrive at any practical selection of kinds to sow. This being so cicarly the case, we, claiming a practical knowledge of the subject, have by selection from the mass reduced the number so as to present an assortment covering every desirable variation. Too much in the garden simply cumbers the ground and adds to a detail of labor already large enough-in fact, two or three sorts of any family are sufficient. If we were asked by a confiding fricnd to sift out from our Catalogue of Seeds a moderate selection such as wonld meet all wants, we would present him something like the following, differing now and then by reason of soil and climate:

\section{RECOMMENDED VARIETIES.}

BIEANS.

First in Market, as an extra early green pod.

Extra Early Red Valentine, as a succession and a green pod stand-by.

Landreth' Pink-Eye Wax, as a standard yellow round-podded wax.

Landreths' Scarlet, as a standard yellow flat-podded wax.

IPEAS.

Landreths' Extra Early, everywhere the unit of excellence. Advancer, an admirable successor.

Telephone, a fine main crop reliance.

\section{CORN.}

Landreths' Early Market, most productive early sort.

Crosby, a sweet sugar successor.

Landreths' Sugar, not surpassed as a main crop.

\section{BEET.}

Best first early is the Eclipse.

Best main crop, Half Round Purple Red-one of the best of the turnip-formed sorts.

\section{CABRAGE.}

Select Very Early Jersey Wakefleld-its popularity proves its worth; for a middle crop, Bloomsdale Early Dwarf Flat Dutch; and for a late crop, Market Gardeners' Late Flat Dutch.

\section{CABBAGE FOR MTDSUMMER AND AUTUMN SOWING IN} FLORIDA AND GULF STATES.

Bloomsdale Early Drumhead, Reedland Early Drumhead and Bloomsdale Early Dwarf Flat Dutch.

\section{CARRO'T.}

For early use, Horn, either Blunt or Pointed; for main crop use Danvers.

\section{CAULIFIOWER.}

Landreths' First, then Snowball.

\section{CEIERT.}

Paris Golden, then White Plume.

\section{CUCUIIBER.}

Earliest bearer, Short Proliflc; for main reliance, White Spine.

EGG-PIANT.

Landreths' Thornless.

\section{IKA I E.}

Rosette-very curly and slow to shoot to seed.

\section{IE'T'TECE.}

First for cutting-Landreths' Earliest Cutting ; not a header. First header-Landreths' Forcing ; very choice.

Main crop-Reliable.

\section{WATERIELOR.}

Best earliest-Round Light Icing.

Good succession-Long Light Icing.

Dixie-mail crop.

Boss-late but unequaled by any known sort

\section{CANTAROUPE。}

Best early-Jenny Lind.

Good succession-Acme and Cape May.

\section{ORER.}

Long Green-very superior.

\section{ONION.}

First early-Pearl, Bermuda Red and White. Second early-Extra Early Red, Autumn White Wax. Main croppers-Silver Skin and Danvers Late ripeners-Southport Globes.

\section{PARSREY.}

Emerald Gem

\section{RADISTR.}

In order of maturity-Earliest White Turnip, Prussian Globe, French Breakfaist, Wonderful Half Long Red, Stuttgart, Strasburg.

\section{SQUASTE.}

Golden Crook-Neck, White Bush for Summer; Boston Marrow and Hubbard for Winter.

\section{TOMATO.}

First ripener-Richmond; follow with Baltimore Prize Taker; then, for maill crop, with T T T and Stone.

\section{TUURNIP.}

Early Red Top Globe followed by Amber Globe; that by Bloomsdale Swede.

\section{POT T正O}

Early Ohio, Farmers' Alliance and Green Mountain.

Pastuzo Extra. On Peas and Beans 16 cents per quart, and Corn 15 cents per quart: other small seeds, 8 cents per pound. Quarter pound and under, and 5 cent und 10 cent Flat Papers, Free of Charge. 


\section{ROOTS FOR STOCK FEEDING.}

In $18 \% 2$ we printed for private presentation to our customers, correspondents and friends a pamphlet entitled "What We Know about Turnips." The purpose was to use it as a means to draw more general attention to a branch of husbandry - root culture-not sufficiently appreciated, as re believed, in this country. That purpose was fully explessed in the introductory remarks, some extracts from which we here reprint:

"This pamphlet is printed in the hope of diffusing useful information to induce greater attention to a most valuable adjuuct in husbandry, and, if more widely regarded, calculated to increase not only the quantity but the quality of our food. The tender, luscious mutton of the English is not attributable to their cooler climate alone, but to the Turnip, Mangold and other succulent roots on which the sheep are fed and fattened for the butcher.

"The value of succulent food, in a hygienic or sanitary view, to man and also to the animals which minister to his wants need not be commented on. All who have paid attention to the subject agree in opinion as to its advantage, indeed absolute necessity, if the preservation of health be properly studied. The long Winters of our Northern States, which arrest vegetation and oblige us to provide green food in silos or dry forage in the mow to be stored up in anticipation of the Winter season, have necessarily induced inquiry and examination as to the class of vegetables which can be produced in greatest abundance at least cost, with least exertion, in the shortest space of time, and with least liability to failure of the crop under unfavorable atmospheric conditions, and also, as of primary importance, of a quality adinitting of preservation for months with slight danger of decay.

"In Great Britain the culture of roots years agu assumed such gigantic importance, it was estimated by writers on political ecouomy that the root product was equiralent to the sum represented by the interest on the national debt-no inconsiderable amount, as everybody knows. Until the culture of roots, as they are termed, was extended aud enlarged in England, animal food was a luxury seldom within the reach of the operative classes, with whom vegetables and farinaceous compounds, not always of the best quality, were the only reliable resources for sustenance. Now meats in some shape are within reach of all-the factory operative, the mechanic, the tradesman and the landholder alike participate; and this change has growu out of, not national prosperity or increased wages, though both are indirectly affected, but the greater breadth of land in root culture, which has so largelyimmensely, it may be said-augmented the productive capacity of the acreage under plough, thus practically bringing nutritious food to every workingman's door.

"Indian Corn-with us the great meat producer, which has played so important a part in the develop- ment of our country, enabling the hardy emigrant from the older settlements to mrest the rilderness from the savage and overcome the forest-is not a product of Great Britain or any portion of the north of Europe, there being known only as an import from America. In this particular we have an adrantage impossible to estimate; but, great as it is, it should not lessen our ezertion to produce succulent food, which augments the value of the farinaceous."

The facts and suggestions stated in our pamplet of 1872 apply with equal force now as then, and may, we hope, impress themselves on the attention of the routhful farmer who has started in agriculture since the pub. lication of our pamphlet. Though me had ourselres, from long experience and our special pursuit in life, appreciated the importance of the subject discussed, and started out with the purpose to impress others, we had, we are free to confess, but faintly understood the popular interest in the matter and the desire for information entertained by the country at large, as erincerl by the demand from every quarter, one hundred thousand copies of the pamphlet having been consumed in editions which followed in quick succession. Besides this large number emanating directly from ourselres, it was reprinted entire in at least tro rural journals and freely quoted by the agricultural press generally:

The principal succulent and saccharine roots. besides the Turnip, raised for cattle feeding are, it is almos: unnecessary to obserre, mainly comprised by the tribes of Beets, Carrots and Parsnips.

In this country the Turnip and, par excellence the Ruta Baga (or "Swede," as it is familiarl called in England) will be, it is probable. erer more fenerally cultivated for stock food than any other root-not that it is the best, but because it can be so readily grown and at small cost. While Beets, Mangolds, Carro:s. etc., demand an entire season to mature, the Turnip is of so quick gromth iu our climate that mithin a jew weeks only after sowing abundant supplies mar be in hand.

We cannot, horrerer, but maintsin that, thouch st some increase of labor iu the production, no expenditure on the farm may in the long run pay betier than an annual crop of Mangolds and Carrots. even if raised only in suffeient quantitr to alternaie with the Ruta Baga, and thus vary the food which the milch cow, the stall-fed ox and the sheep crare equally with man.

The subject is one which concerns the Tnion-our prosperity cannot adrance faster than our progress in agriculture, whether as planters, grain producers, siock breeders or dairymen. When they prosper all in 31 s. tries participate. The railroads, the mills. the forzes, the shipping find profitable emplorment-all are sulw ordinate to the farmer's industry.

DAVID LANDRETH \& SONS 


\section{A NEW BEET.}

After the red-fleshed Eclipse and Egyptian, the almost white-fleshed Bassano and the red and white ringed Forcing and Philadelphia Beets-all of which reach maturity in the order named-there follows a class of redfleshed turnip-shaped Beets, known variably as Red Turnip, Edmunds', Dewing's. All these are excellent, though they vary according to the fancy of the Seed Farmer who grows from a seed stock selected according to his personal notions as to color of leaf, and color, size, shape, and maturity of bulk. For example, we have been growing Beet seed for a century and have radically changed the type of many varieties. We now have a selection of red turnip-shaped Beet, which we offer under the name of

\section{"Bloomsdale Half Round Purple Red,"}

and recommend it for valuable table qualities. A well-grown crop, drilled in rows at fifteen inches apart and thinned to three inches, should produce twelve tons to the acre. Pkts. 5c. and 10c.; per oz. 10c.; $\frac{1}{4} 1 \mathrm{~b} .15 \mathrm{c} . ; 1 \mathrm{~b} .50 \mathrm{c}$.

\section{The Bloomsdale Pea.}

A WHITE-SEEDED PEA, EACH VINE PRODUCING A LARGE NUMBER OF LONG, SHOWY PODS CONTAINING FROM EIGHT TO TEN SEEDS.

Exceedingly profitable to the Market Gardener, producing to the acre more than double the number of barrels than any other garden Pea in cultivation. Pods mature for market about two weeks after the Extra Early and about ten days ahead of the Marrowfats, continuing in bearing ten days. Vines deep green in color and growing to a height of thirty-six inches. It should be drilled in rows three to four feet apart. We recommend this Pea highly both as a market garden and family garden Pea. It might be called a main crop Pea.

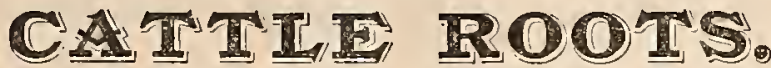

We should like to turn the thoughts of farmers more generally to the contemplation of the subject of growing roots of Cattle Beets-Mangel Wurzels, as they are known by those familiar with the subject. No crop which can be drilled will yield so large a bulk of palatable and nutritious food for Autumn and Winter feeding, as twenty-five to thirty tons to the acre can be grown under good conditions, while in the climate of England ninety and one hundred tons to the acre is not uncommon. As compared with Turnips, analyses show that seventy-five pounds of Mangolds possess as much nutritive qualities as one hundred pounds of Turnips.

\section{NEW Publications.}

In addition to the publications offered in our Catalogue, we have just published a series of interesting special papers, among which are the following:

"Landreth on Cabbage," "Sugar Corn Culture,"
"Pea Culture," "Landreth on Cucumber,"
"Tomato Culture for the Gardener and Canner,"
"Seeds for Midsummer and Autumn Sowing in the Gulf States,"

THE LATTER A PAMPHLET OF TWENTY-FOUR PAGLS, GIVING ALSO SOME OF THE PRINCI-

PAL STATISTICS OF MARKET GARDENING IN THE GULF STATES FOR NORTHERN MARKETS.

COPIES WILL BE SENT FREE TO OUR CUSTOMERS UPON APPLICATION.

LANDRETHS' SEEDS are sold by 12,929 Merchants in the United States, including Alaska, and by others in Canada, Mexico, South America, West Indies, China, Japan, India and Australia.
Adaress, simpiy,

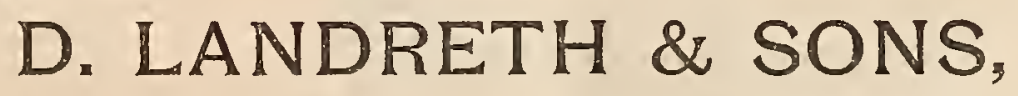

PHILADELPHIA, PA. 


\section{THE UNITED STATES MAIL}

\section{CARRIES \\ Landreths' Seeds to Every Post-Office}

\section{LANDRETH PAYS THE POSTAGE ON SEEDS ORDERED IN FLAT PAPERS AND OUNCES.}

THE PURCHASER pays the postage on Seeds ordered in pounds or fractions of pounds, the rate being eight cents per pound-this on Peas, Beans and Corn is equal to eight cents a pint.

ORDERS FOR SEEDS must be accompanied by the cash, which can be remitted by Check, Draft, Post-Offce Money-Order or Postal Note. To the value of the Seeds should be added the eight cents per pound to cover postage-otherwise the eight cents per pound will be deducted from the cash sent and the quantity of Seed reduced accoraingly.

WE WILL POST SEFDS ordered by mail the day the order is received. No order will be too small to receive our most particular attention; no order will be too large to be executed. We have mailed as much as a ton of seeds in four-pound packages to a single address. Nothing of a business nature is a bother to us. See our Remarks to Purchasers on second page of corer.

Our business, founded in 1784 , is the seventh in order of the old Commercial Establishments in Phila. delphia, and the tenth in the United states, there being not thirty firm in America of over Ioo years of estabishment.

Address letters simply

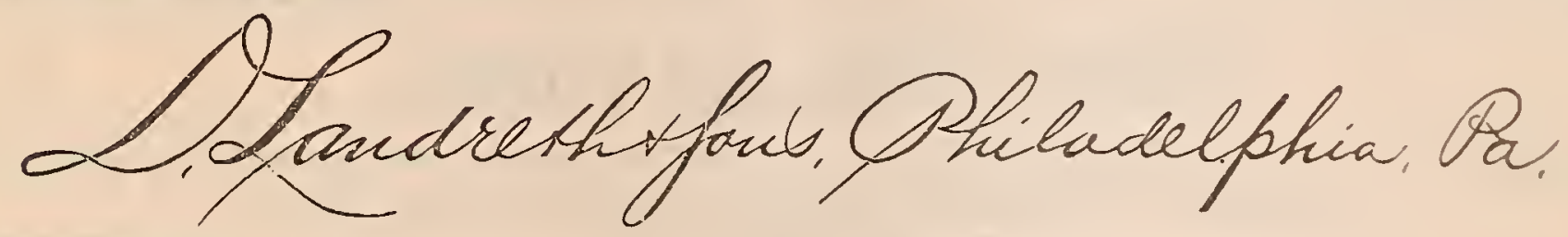

\section{A CHOICE FIELD CORN,}

\section{Early Amber Eight-Rorued Flint.}

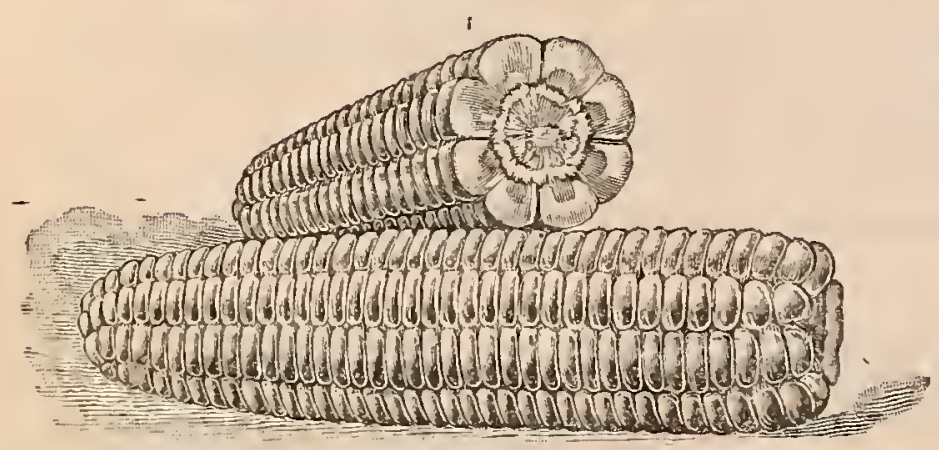

A Field Corn adapted for culture in sections where ire growing season is too short for sof-grainec varieties. Also valuable for late replenting in the Middle States. Grown in the latitude of Nor:Le-d? Pennsylvania. The height of stall about $\leq 1$ : to 5 feet. Ears maturing for husking in about nineis days from germination. Per plits. $5 c$, acd :0c; per qt. 20c.; per 1-4 bush. 80c.; per bush. $\$ 325$.

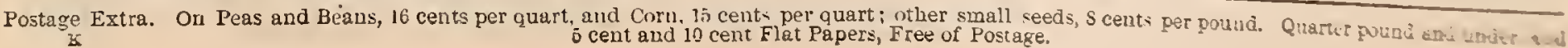




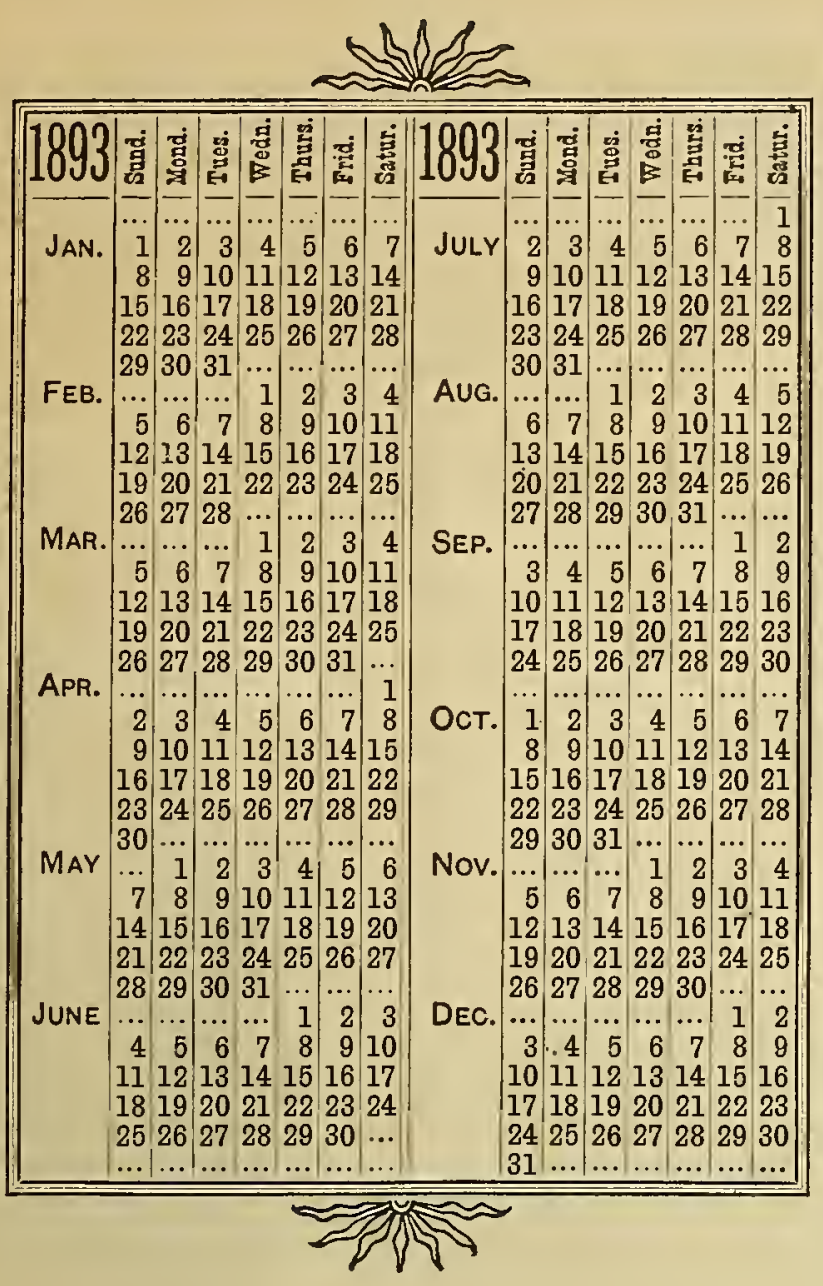

\section{Ornamental Trees, Plants,} Vines, Fruits, Etc.,

Will be furnished upon application. It will be found very complete, containing practical descriptious of nearly everytling desirable....
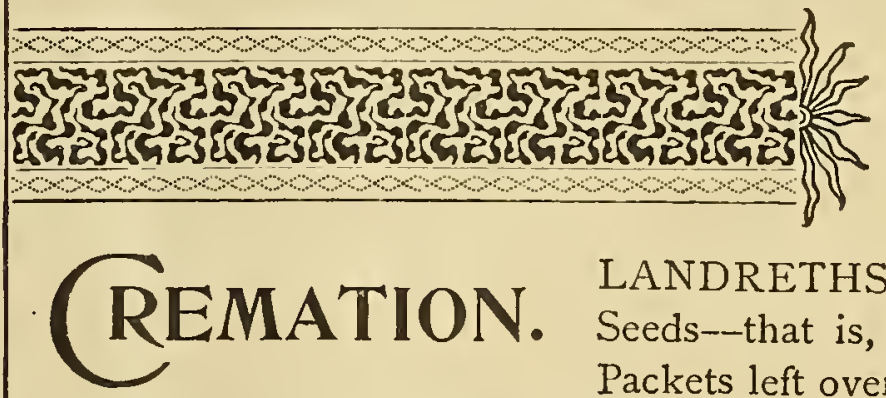

LANDRETHS cremate their Seeds--that is, they burn Seed Packets left over at end of season. All of Landreths' Packets are dated with year of issue, and if not burned, the date will show that they are old. Do Comnission Seedsmen burn their Seed? No!

Which is most safe to purchase, Landreths' Seeds in dated bags, or Commission Seeds in bags NOT dated, and consequently of uncertain age, possibly old travelers and as dead as Julius Caesar?

The Cremation system should commend itself to all who will give it a moment's thought.

\section{MINNESOTA AND DAKOTA SPRING WHEAT.}

Scotch Fife

It.is sown in April and May and cut from Ist August to I5th September. Its advantages are that it is exceptionally hard in grain and rich in gluten and is always at a premium for mixing with Winter wheat before crushing.

We recommend its trial in elevated sections of any of the Middle States and in all of the Northern States, as it may prove of value in Winter wheat sections to supplement crops of Winter wheat injured by frost, as it can be sown before Oat sowing season.

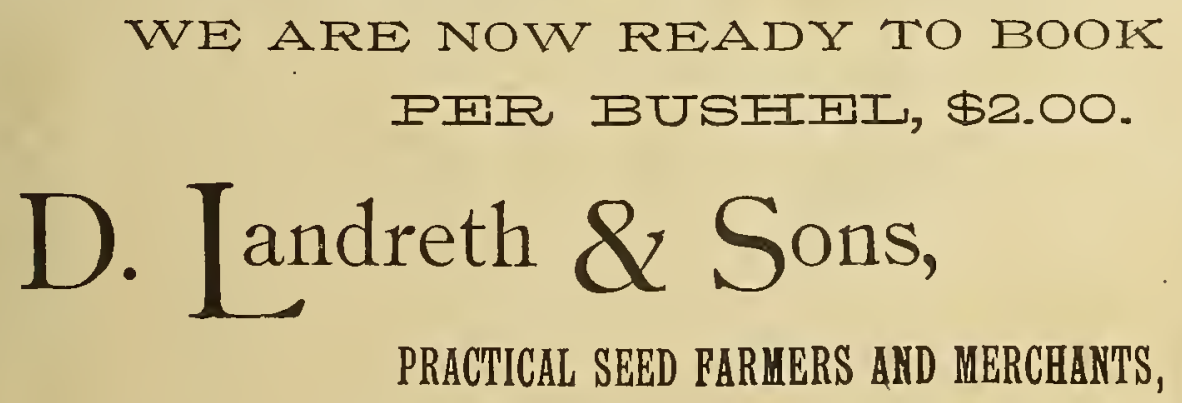

Grown in North Dakota. This selection, which we offer, grows about 38 inches in height, and has proven the best in the climates west of St. Paul and north above the line of the Canadian Pacific Railroad, over which vast section of country it frequently yields thirty bushels to the acre, and often more than double that quantity. 
